Fossil Energy Program

Fossil Energy Program Annual Progress Report for April 1994 Through March 1995

R. R. Judkins

Program Manager

Date: June 1995

Prepared for the DOE Office of Fossil Energy (AA, AB, AC, AW, AZ, SA)

Prepared by the

OAK RIDGE NATIONAL LABORATORY

Oak Ridge, Tennessee 37831-6285 managed by

LOCKHEED MARTIN ENERGY SYSTEMS, INC. for the

U.S. DEPARTMENT OF ENERGY under Contract DE-AC05-84OR21400

$v_{0}$

DISTRIBUTION OF THIS DOCUMENT IS UNUGATED 



\section{DISCLAIMER}

Portions of this document may be illegible in electronic image products. Images are produced from the best available original document. 


\section{CONTENTS}

ABSTRACT $\ldots \ldots \ldots \ldots \ldots \ldots \ldots \ldots \ldots \ldots \ldots \ldots$

1. INTRODUCTION ......................

1.1 Materials Research and Development . . . . . . . . . . . . 2

1.2 Environmental Analysis Support $\ldots \ldots \ldots \ldots \ldots$

1.3 Bioprocessing Research . . . . . . . . . . . . . . 3

1.4 Coal Combustion Research $\ldots \ldots \ldots \ldots \ldots \ldots$

1.5 Fossil Fuels Supplies Modeling and Research $\ldots \ldots \ldots \ldots$

1.6 Advanced Turbine Systems . . . . . . . . . . . . . . . 3

2. MATERIALS RESEARCH AND DEVELOPMENT $\ldots \ldots \ldots \ldots \ldots$

2.1 Forced Chemical Vapor Infiltration of Tubular Geometries:

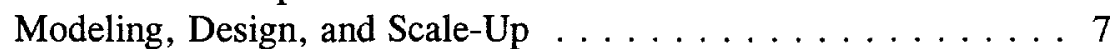

2.2 Oxide Coating Development . . . . . . . . . . . . . 17

2.3 Development of Oxidation/Corrosion-Resistant Composite

Materials and Interfaces . . . . . . . . . . . . . . . . 21

2.4 Development of Microwave-Heated Diesel Particulate Filters . . . . 35

2.5 A Novel Carbon Fiber Based Porous Carbon Monolith . . . . . . . . 45

2.6 Investigation of Austenitic Alloys for Advanced Heat Recovery and Hot-Gas Cleanup Systems . . . . . . . . . . . . . . 57

$2.7 \mathrm{Cr}_{2} \mathrm{Nb}$-Based Alloy Development $\ldots \ldots \ldots \ldots \ldots$

2.8 Development of Iron Aluminides . . . . . . . . . . . . . 77

2.9 High-Strength Iron Aluminide Alloys . . . . . . . . . . . . . 85

2.10 Low-Aluminum Content Iron-Aluminum Alloys . . . . . . . . . . . . 91

2.11 High-Temperature Corrosion Behavior of Iron Aluminide

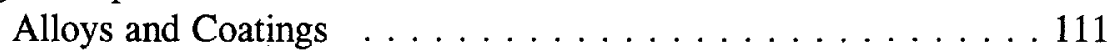

2.12 ODS Iron Aluminides . . . . . . . . . . . . . . . . . . . 123

2.13 Mechanically Reliable Scales and Coatings . . . . . . . . . . . 137

2.14 Carbon Formation and Metal Dusting in Hot-Gas Cleanup

Systems of Coal Gasifiers . . . . . . . . . . . . . . 147

2.15 Materials Support for HITAF . . . . . . . . . . . . . . . 153

3. ENVIRONMENTAL ANALYSIS SUPPORT $\ldots \ldots \ldots \ldots \ldots$

3.1 Environmental Support to the Clean Coal Technology Program . . . 167 
4. BIOPROCESSING RESEARCH . . . . . . . . . . . . . . 169

4.1 Fundamental Bioprocessing Research for Coal Applications . . . . . 171

4.2 Advanced Bioreactor Systems for Gaseous Substrates:

Conversion of Synthesis Gas to Liquid Fuels and

Removal of $\mathrm{SO}_{\mathrm{x}}$ and $\mathrm{NO}_{\mathrm{x}}$ from Coal Combustion Gases . . . . . . 179

4.3 Removal of Heteroatoms and Metals from Heavy Oils

by Bioconversion Processes . . . . . . . . . . . . . . 185

4.4 Renewable Hydrogen Production for Fossil Fuel Processing . . . . . 187

5. COAL COMBUSTION RESEARCH $\ldots \ldots \ldots \ldots$

5.1 Analysis of FBC Deterministic Chaos . . . . . . . . . . . . 201

5.2 Mild-Gasification Product Characterization . . . . . . . . . . 205

6. FOSSIL FUELS SUPPLIES MODELING AND RESEARCH $\ldots \ldots 207$

6.1 Strategic Petroleum Reserve Planning and Modeling . . . . . . . . . 207

7. ADVANCED TURBINE SYSTEMS . . . . . . . . . . . . . . . . . 209

7.1 Materials/Manufacturing Element of the Advanced Turbine

Systems Program . . . . . . . . . . . . . . . . . . 209 


\title{
FOSSIL ENERGY PROGRAM ANNUAL PROGRESS REPORT FOR APRIL 1994 THROUGH MARCH $1995^{1}$
}

\author{
R. R. Judkins, Program Manager
}

\begin{abstract}
This report covers progress made during the period April 1, 1994, through March 31, 1995 , for research and development projects that contribute to the advancement of various fossil energy technologies. Projects on the Fossil Energy Program are supported by the DOE Office of Fossil Energy, the DOE Morgantown Energy Technology Center, the DOE Pittsburgh Energy Technology Center, the DOE Fossil Energy Clean Coal Technology Program, the DOE Bartlesville Project Office, and the DOE Fossil Energy Office of Strategic Petroleum Reserve.
\end{abstract}

\section{INTRODUCTION}

Paul T. Carlson

The Oak Ridge National Laboratory (ORNL) Fossil Energy Program research and development activities, performed for the Department of Energy (DOE) Assistant Secretary for Fossil Energy, cover the areas of coal, clean coal technology, gas, petroleum, and support to the Strategic Petroleum Reserve. The coal activities include materials research and development; environmental analysis support; bioprocessing of coal to produce liquid or gaseous fue's; and coal combustion research. The work in support of gas technologies includes activities on the Advanced Turbine Systems Program, primarily in the materials and manufacturing aspects. Several activities are contributing petroleum technologies in the areas of computational tools for seismic analysis and the use of bioconversion for the removal of impurities from heavy oils.

The Fossil Energy Program has projects in several ORNL divisions. Included as part of the Fossil Energy Program is the technical management of all activities on the DOE Fossil Energy Advanced Research and Technology Development (AR\&TD) Materials Program. The AR\&TD

\footnotetext{
${ }^{1}$ Research sponsored by the U.S. Department of Energy, Office of Fossil Energy, under contract DE-AC05-84OR21400 with Lockheed Martin Energy Systems, Inc.
} 
Materials Program includes research at six other DOE laboratories, at universities, and at industrial organizations.

\subsection{MATERIALS RESEARCH AND DEVELOPMENT}

Materials research and development activities at Oak Ridge National Laboratory include development of ceramic composites for high temperature applications; new alloys with unique mechanical properties for advanced fossil energy systems; development of functional materials, such as ceramic filters, ceramic membranes, and carbon materials; and corrosion research to understand the behavior of materials in coal processing environments. The transfer of technology developed on this program is enhanced through interactions with industry and joint research programs with those interested in using the technology. Transfer to industry of the technology developed on the program has been an important activity this year, and this commitment to technology transfer is reflected in an active CRADA involvement. Materials technical support and failure analyses are provided to projects on the Clean Coal Technology Program.

\subsection{ENVIRONMENTAL ANALYSIS SUPPORT}

Activities in environmental analysis support included assistance to the DOE Morgantown and Pittsburgh Energy Technology Centers (METC and PETC) in reviewing and preparing documents required by the National Environmental Policy Act (NEPA) for several projects selected for the Clean Coal Technology Program. An important activity was the preparation for METC of a draft Environmental Assessment (EA) for the proposed Externally Fired Combined Cycle Project in Warren, Pennsylvania. Also prepared for METC was a draft EA for the proposed Four Rivers Project to demonstrate pressurized circulating fluidized bed technology in Calvert City, Kentucky.

The Fossil Energy Program also provided assistance to PETC in satisfying the NEPA requirements for the retirement and dismantling of the Advanced Coal Liquefaction Research and Development Facility in Wilsonville, Alabama. 


\subsection{BIOPROCESSING RESEARCH}

Work on the Fossil Energy Bioprocessing Research Program includes fundamental research for coal applications that investigates the use of enzymes inorganic media, bioreactor development for coal liquefaction, and separations of enzyme and coal liquids. In addition, there are studies of advanced bioreactor systems

\subsection{COAL COMBUSTION RESEARCH}

It is known that fossil energy combustion devices, such as fluidized beds and pulsed combustors, can exhibit characteristic features of deterministic chaos. The ability to measure and describe chaotic components will contribute to greatly improved methods for characterizing, modeling, designing, and controlling commercial fossil energy processes such as combustion, coal gasification, hot-gas cleanup, and oil retorting. The Fossil Energy Program is involved in the evaluation of chaotic components in data from fluidized beds and other coal combustion processes. Work is also being concluded on the characterization of liquid and char coproducts from mild gasification of coal.

\subsection{FOSSIL FUEL SUPPLIES MODELING AND RESEARCH}

The Strategic Petroleum Reserve (SPR) is a government-owned stockpile of crude oil intended to serve as a buffer against possible oil market disruptions. The overall purpose of this project is to develop and apply improved models and tools for SPR management. Current project efforts emphasize developing new modeling tools to explicitly and flexibly portray oil market uncertainty and SPR planning risk.

\subsection{ADVANCED TURBINE SYSTEMS}

The DOE Offices of Fossil Energy and Energy Efficiency and Renewable Energy have initiated a program to develop advanced turbine systems for power generation. The objective of the Advanced Turbine Systems (ATS) Program is to develop ultra-high efficiency, 
environmentally superior, and cost competitive gas turbine systems for utility and industrial applications. One of the supporting elements of the ATS Program is the Materials/Manufacturing Technologies Task. The objective of this element is to address the critical materials and manufacturing issues for both industrial and utility gas turbines. 


\title{
2. MATERIALS RESEARCH AND DEVELOPMENT
}

\author{
N. C. Cole
}

Materials research and development activities at Oak Ridge National Laboratory include development of ceramic composites for high temperature applications; new alloys with unique mechanical properties for advanced fossil energy systems; development of functional materials, such as ceramic filters, ceramic membranes, and carbon materials; and corrosion research to understand the behavior of materials in coal processing environments. The transfer of technology developed on this program is enhanced through interactions with industry and joint research programs with those interested in using the technology. Transfer to industry of the technology developed on the program has been an important activity this year, and this commitment to technology transfer is reflected in an active CRADA involvement. Materials technical support and failure analyses are provided to projects on the Clean Coal Technology Program. 



\subsection{FORCED CHEMICAL VAPOR INFILTRATION OF TUBULAR GEOMETRIES: MODELING, DESIGN, AND SCALE-UP}

D. P. Stinton, T. M. Besmann, W. M. Matlin, and T. L. Starr

\section{INTRODUCTION}

In advanced indirectly fired coal combustion systems and externally fired combined cycle concepts, ceramic heat exchangers are required to transfer heat from the hot combustion gases to the clean air that drives the gas turbines. For high efficiencies, the temperature of the turbine inlet needs to exceed $1100^{\circ} \mathrm{C}$ and preferably be about $1260^{\circ} \mathrm{C}$. The heat exchangers will operate under pressure and experience thermal and mechanical stresses during heating and cooling, and some transients will be severe under upset conditions. Silicon carbide-matrix composites are promising for such applications because of their high strength at elevated temperature, light weight, thermal and mechanical shock resistance, damage tolerance, and oxidation and corrosion resistance.

Fiber-reinforced composite tubes of several fiber architectures were fabricated by forced chemical vapor infiltration (FCVI) and characterized. Unfortunately, long times ( $\sim 150$ hours) were required to thoroughly densify the tubes. An objective of the current investigation was to optimize the forced CVI process so that composite tubes could be fabricated in much shorter times. To aid in such optimization, a computer code which models the CVI process was used to identify critical process parameters.

Finally, successful demonstration of the utility of composite tubes for these applications will require the testing of near-full scale components. As a result a new infiltration system was designed and constructed to prepare $10-\mathrm{cm}$ diameter tubes, and is described in this report. 


\title{
DISCUSSION OF CURRENT ACTIVITIES
}

\author{
Tubular Specimen Fabrication
}

\section{Preforms}

Nicalon ceramic grade fibers (Nippon Carbon Co., Tokyo, Japan) were utilized for the fabrication of the preforms. Nicalon is a SiC-based polymer-derived fiber that is microcrystalline/amorphous in nature and contains significant amounts of silica. ${ }^{1,2}$ Three types of preforms were fabricated: Cloth-wrapped, angle-wound, and braided. The cloth wrapped preforms were prepared by tightly wrapping strips of Nicalon cloth ( $20 \mathrm{~cm}$ wide by $220 \mathrm{~cm}$ long) onto $2.54 \mathrm{~cm}$ diameter graphite mandrels to form tubes with fiber contents of $\sim 32 \mathrm{vol} \%$. The cloth was a plain weave with 500 fibers per tow. Higher fiber loading was certainly desired, however, it was not possible to wrap the cloth any tighter by hand.

The angle-wound preforms were prepared by winding onto a graphite mandrel with the 500 fiber tows wound $10^{\circ}$ off the hoop direction to provide some axial strength. Adjacent fiber tows were placed in contact with each other to prevent formation of large pores. The winding procedure yielded a preform with a fiber loading of $\sim 40 \%$.

Quadrax Corp. for this effort prepared 3-dimensional braided preforms on graphite mandrels, also using 500 fiber tows. The braid was specially designed to have a high fiber loading, $\sim 38 \%$, since typical braided materials have only $15-30$ vol. \% fibers.

Densification

Forced chemical vapor infiltration (FCVI) as developed at the Oak Ridge National 
Laboratory has been used to fabricate composites of thick-walled tubular geometry. Details of the FCVI process have been reported in numerous publications..$^{3-6}$ Briefly, fibrous preforms are constrained by special fixturing such that reactants are forced through the walls of the preform (Fig. 1). Gaseous reactants enter the furnace through tubing that runs within the water cooling passage of a stainless steel injector. Reactants flow from the tubing in the cooling passage into a graphite gas distributor and are dispersed along the length of the preform through parallel slots in the distributor. Reactants then proceed uniformly through holes in the graphite mandrel into the preform. A temperature gradient is established through the preform wall such that decomposition of the methyltrichlorosilane $\left(\mathrm{CH}_{3} \mathrm{SiCl}_{3}\right.$ or $\left.\mathrm{MTS}\right)$ precursor and deposition of $\mathrm{SiC}$ occurs in the presence of hydrogen as the gases approach the higher temperature regions of the preform. As the density and thermal conductivity of the preform increases, deposition moves progressively toward the inner diameter of the tube. The duration of infiltration is therefore controlled by the temperature gradient throughout the preform and the reactant flow.

Densification of tubular preforms $(2.5 \mathrm{~cm}$ inner dia. by $0.6 \mathrm{~cm}$ wall thickness by $\sim 20 \mathrm{~cm}$ long) required infiltration times of $\sim 150$ hours. Infiltration times were excessively long because of the steep temperature gradient through the preform (from $\sim 1200^{\circ} \mathrm{C}$ on the outside of the preform to about $500^{\circ} \mathrm{C}$ on the inside of the preform). Temperatures were determined using a special preform instrumented with a thermocouple on the inner diameter of the preform. A modification was then made to the processing equipment by removing the graphite gas distributor, leaving only an air gap between the 
graphite mandrel and the stainless steel injector. Infiltration of tubes using this equipment was accelerated considerably. The temperature along the inner diameter of the fibrous preform was increased to $730^{\circ} \mathrm{C}$ and infiltration times were reduced to approximately $40 \mathrm{~h}$. The external surfaces of the tubes were sealed with a chemical vapor deposited overcoat of $\mathrm{SiC}$.

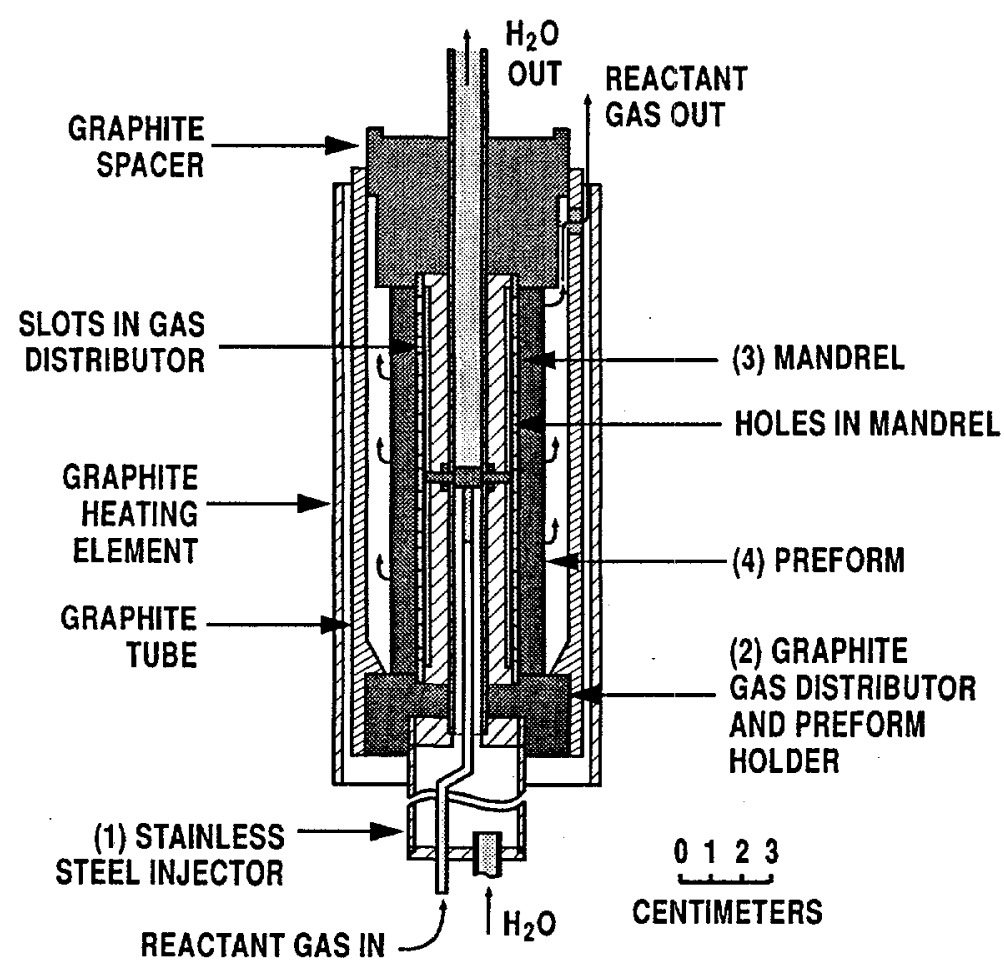

Fig. 1. Schematic of the small-scale FCVI unit for fabricating tubular composites.

\section{Process Modeling}

The small-scale FCVI system has been modeled using the computer code GTCVI, which utilizes a three-dimensional finite volume representation of the system and considers mass and heat transfer and chemical kinetics. ${ }^{7}$ Figure 2 contains flow vectors, isotherms, and a density profile for the system at $40 \mathrm{~h}$. The centerline is represented 

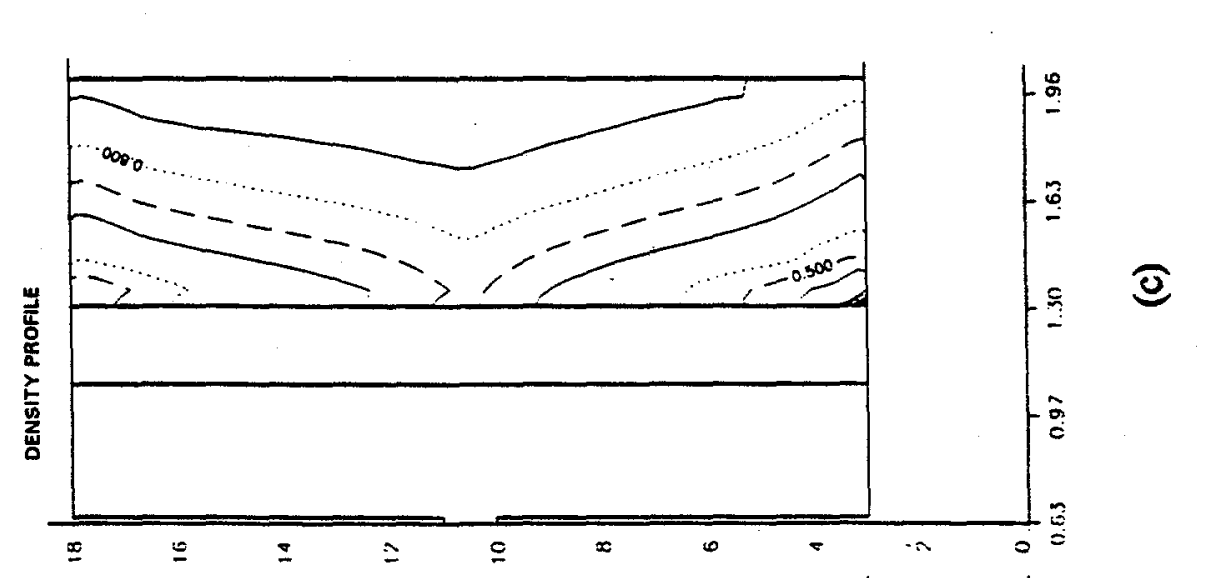

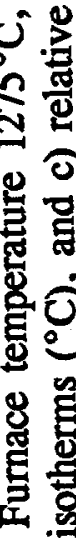

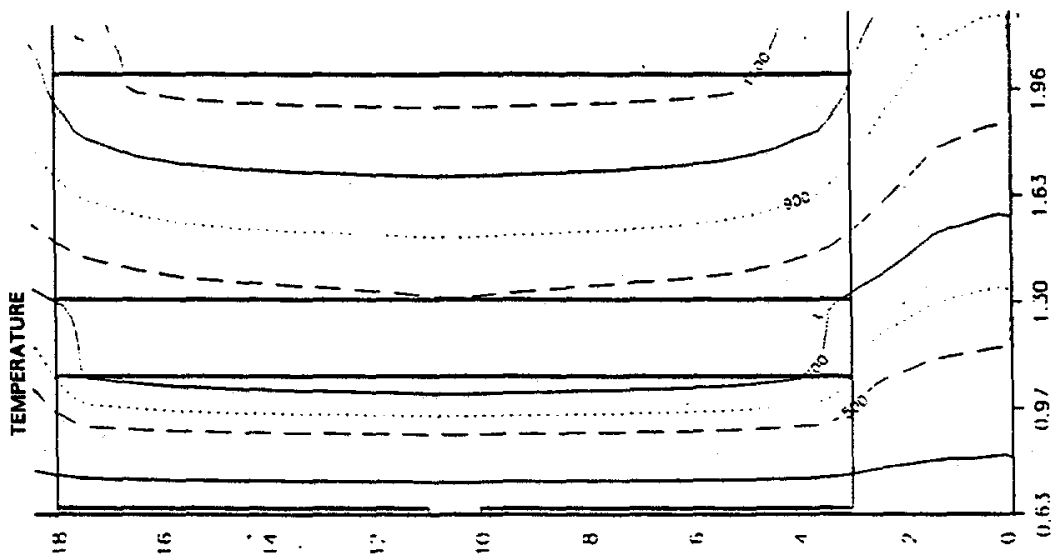

ํํㄹ
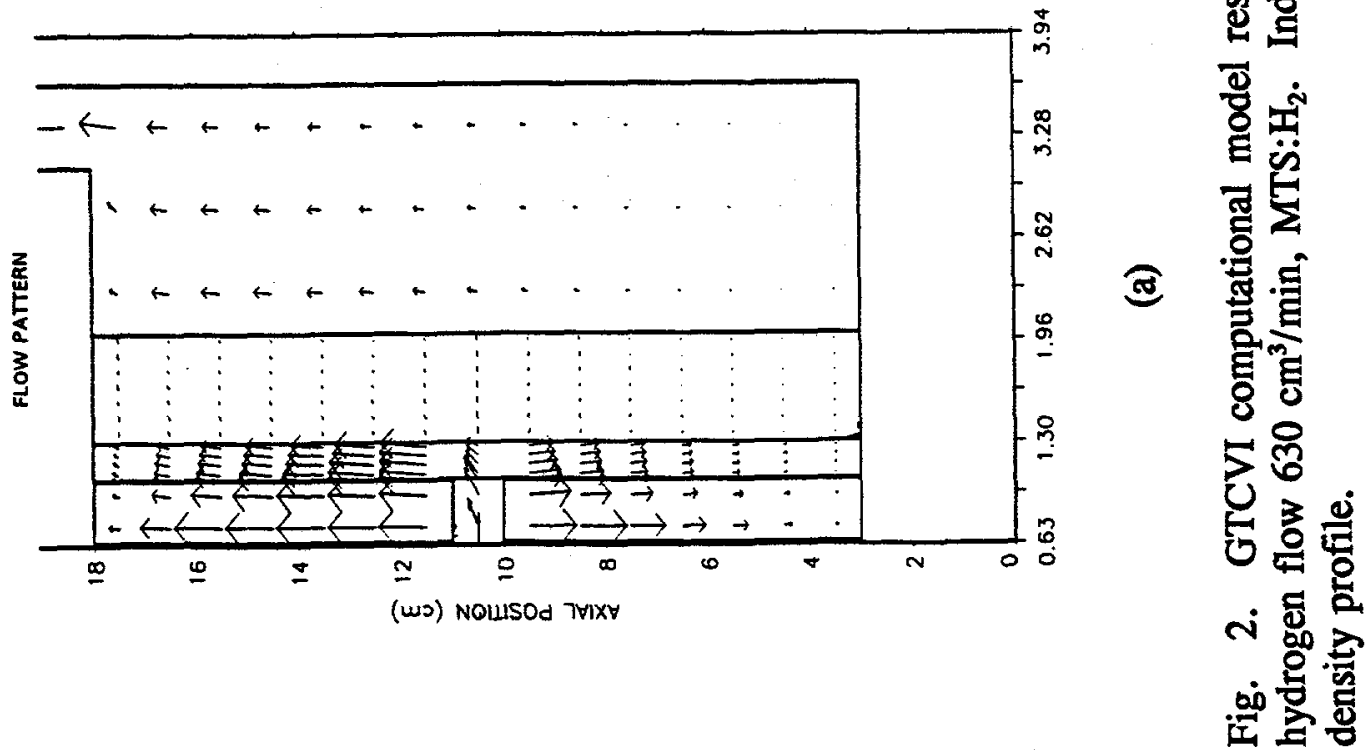
by the $y$ axis, followed radially by the flow tube, the annular space, the mandrel, and the preform. It is apparent that flow is restricted in the lower volume of the tube due to the presence of only a single inlet to the annulus. Heat loss at the ends also results in a temperature depression. The effect of on the uniformity of infiltration is seen in the density profile (Fig. 2c) which reveals, asymmetric lower density regions at the ends, with the lower end having a somewhat lower density.

Non-destructive Evaluation

Computerized tomographic X-ray images were obtained of radial sections of the infiltrated tubes using a Scientific Measurement Systems Model 101B+ industrial system. The unit makes translate-rotate scans of specimens using a $420 \mathrm{kV}$ X-ray tube source with a linear array of 125 collimated detectors. Figure 3 shows images for the three densified tubes exhibiting several problems. Images of the cloth-wrapped tube reveal significant delamination and large porosity between cloth layers (Fig. 3a). Angle-wound preforms resulted in a composite with circumferentially and radially oriented porosity (Fig. 3b). And the braided tubes had large pore located near the outer diameter (Fig. 3c). All these flaws are due to the nature of the preform or its fabrication. 


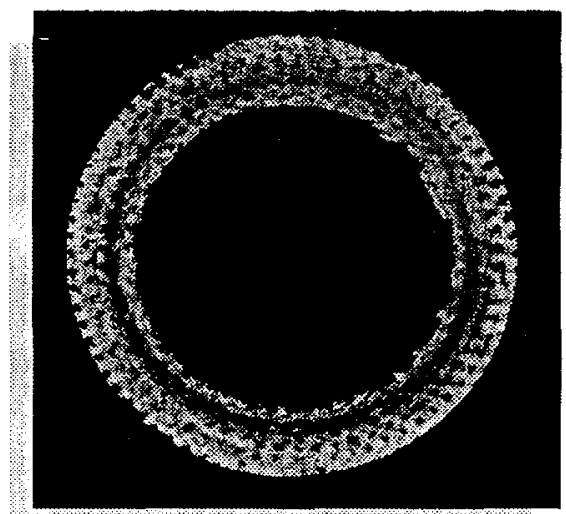

Top

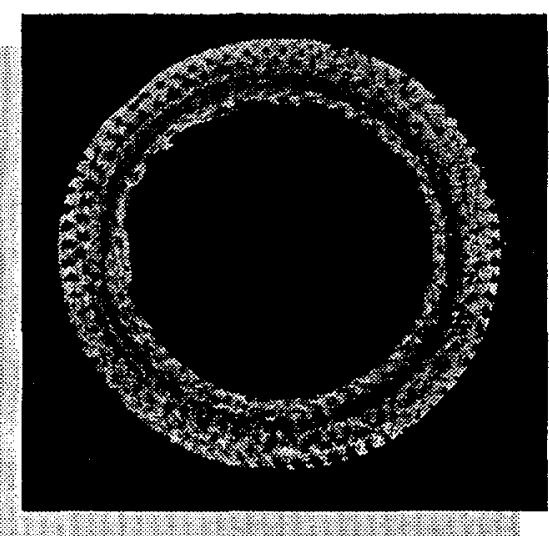

Middle

(a)

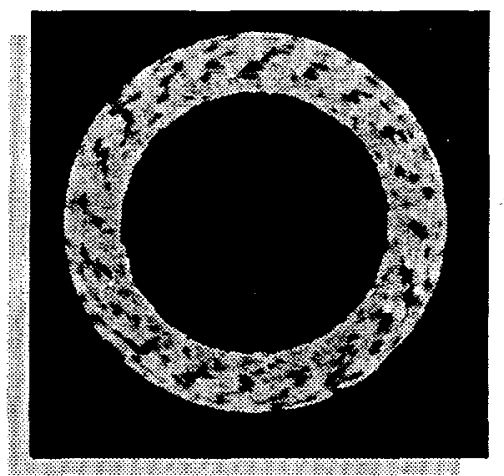

Bottom

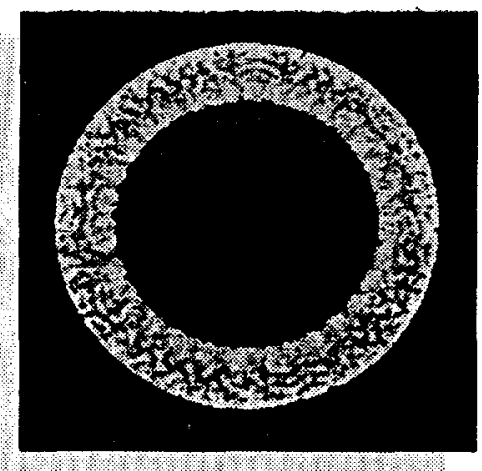

Bottom

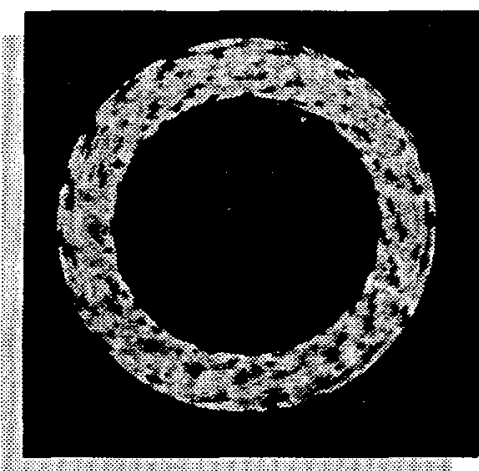

Middle

(b)

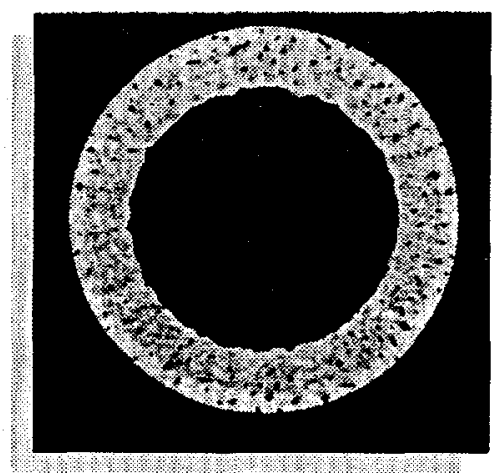

Middle

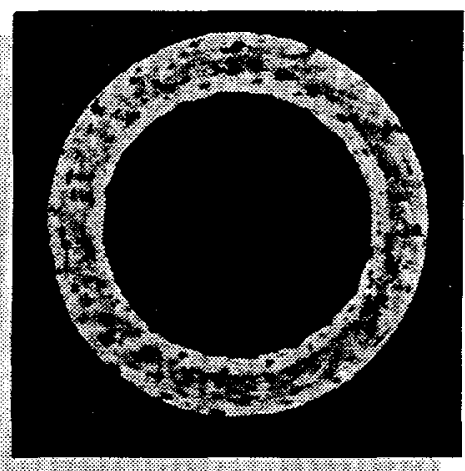

Top

(c)

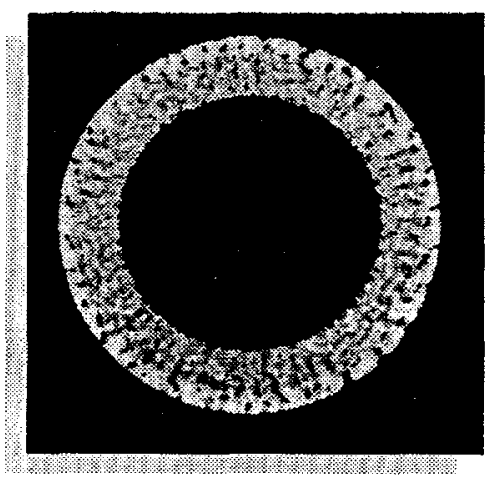

Top

Fig. 3. Computed X-ray tomographic images of tubes densified from a) cloth-wrapped, b) angle-wound, and c) braided preforms. The tubes have a 4-cm outer diameter. 


\section{Scale-up}

A scale-up FCVI system for tubular shapes was designed and constructed by American Furnace Co., Knoxville, TN, to prepare 10-cm outer diameter tubes. Utilizing the experience developed with the smaller system described above, significant improvements were incorporated into the scale-up design (Fig. 4). Instead of single gas path into the preform from the injector, there are multiple entry points. There is greater flexibility in controlling the inner diameter (cooled-side) temperature through the use of forced air or water as the coolant. The system also allows sealing of the ends of the preform via flanges at the ends of the mandrel. With the smaller system such seals were made by pressure-fitting furnace components against the end of the preform, which often deformed and did not make a good seal, resulting in leakage of precursor gases out of the end of the preform. The scale-up system is completing installation.

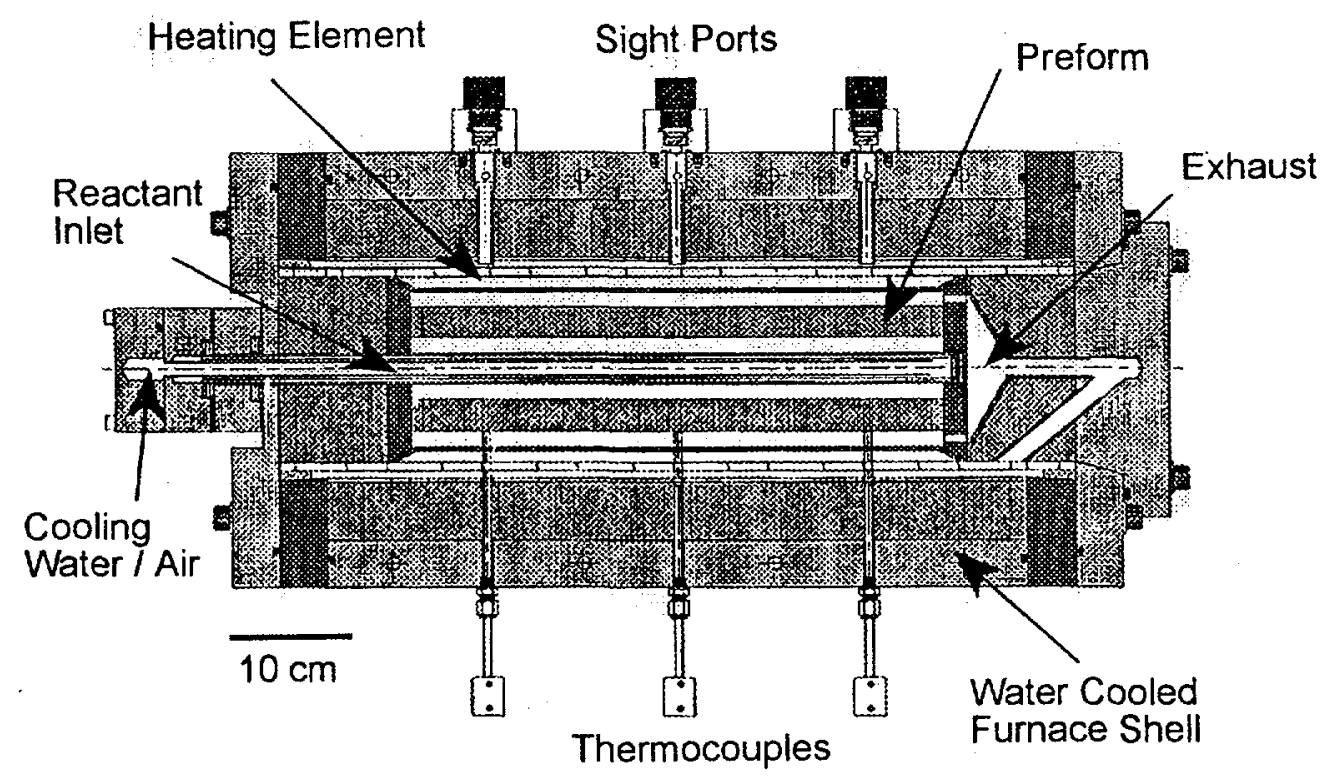

Fig. 4. Schematic of the scale-up FCVI system for preparing 10-cm diameter tubular composites. 


\section{CONCLUSIONS}

Tubular composites of Nicalon/SiC can be fabricated using FCVI, however, the first generation apparatus allows insufficient control to prepare uniformly dense components. A computational model of the FCVI system was used to identify key issues in densification. The results indicated that adjustment of the temperature gradient would be beneficial, which when implemented allowed reduction of infiltration times from $\sim 150 \mathrm{~h}$ to $\sim 40 \mathrm{~h}$. Non-destructive evaluation revealed issues related to organized porosity in preforms, which may result in flaws effecting ultimate strength.

Stiffness measurements indicated that the materials maintain their properties to at least $800^{\circ} \mathrm{C}$, although the effect of axial nonuniformity of densification can be detected. Finally, a scale-up system to produce 10-cm diameter tubular shapes has been constructed which is designed to overcome the limitations of smaller-scale system.

\section{REFERENCES}

1. S. Yajima, et al., J. Am. Ceram. Soc., 59[7-8], 324 (1976).

2. S. Yajima, et al., Nature, 27[21], 706 (1979).

3. D. P. Stinton, R. A. Lowden, and T. M. Besmann, in Proceedings of the Sixth Annual Conference on Fossil Energy Materials, Oak Ridge National Laboratory Report ORNL/FMP-92/1, (1992) pp 3-10.

4. D. P. Stinton, A. J. Caputo, and R. A. Lowden, Am. Ceram. Soc. Bull., 65[2], 347 (1986).

5. D. P. Stinton, T. M. Besmann, and R. A. Lowden, Am. Ceram. Soc. Bull. 67[2], 350 (1988).

6. T. M. Besmann, B. W. Sheldon, R. A. Lowden, and D. P. Stinton, Science, 253, 1104 (1991). 
7. T. Starr, A. Smith, T. Besmann, J. McLaughlin, and B. Sheldon, in High Temperature Matrix Composites, edited by R. Naslain, J. Lamon, and D. Doumeingts (Woodhead Pub. Ltd., Cambridge, 1993), pp. 231-240. 


\subsection{OXIDE COATING DEVELOPMENT}

\section{P. Stinton}

\section{INTRODUCTION}

Monolithic SiC heat exchangers and fiber-reinforced SiC-matrix composite heat exchangers and filters are susceptible to corrosion by alkali metals at elevated temperatures. Protective coatings are currently being developed to isolate the $\mathrm{SiC}$ materials from the corrodants. Unfortunately, these coatings typically crack and spall when applied to SiC substrates. The purpose of this task is to determine the feasibility of using a compliant material between the protective coating and the substrate. The low-modulus compliant layer could absorb stresses and eliminate cracking and spalling of the protective coatings.

\section{BACKGROUND}

Silicon carbide was selected for use as hot-gas filter and heat exchanger materials because of its excellent thermal shock resistance, exceptional mechanical properties at high temperature, high thermal conductivity, and relatively low cost. Unfortunately, SiC ceramics are susceptible to corrosion by alkali metals at high temperatures and therefore not viable for extended service in fossil systems. In contrast, oxides such as alumina are much more stable in corrosive environments but are susceptible to thermal shock and creep at high temperatures. In order to take advantage of SiC's attractive properties, protective oxide coatings will need to be developed to isolate the alkali metals from the SiC. Fiber-reinforced SiC-matrix heat exchangers overcoated with stable oxides should possess adequate mechanical properties and corrosion resistance.

\section{DISCUSSION OF CURRENT ACTIVITIES}

The mechanical properties of fiber-reinforced SiC-matrix composites will likely degrade with time in fossil environments because of the presence of alkali metals. Therefore, coatings for SiC-matrix composites are being developed to isolate the corrodants from the composite materials. Unfortunately, protective coatings frequently crack or spall because of the mismatch in coefficients of thermal expansion between the substrate and coating. Stress concentrations in the coating may 
be avoided if a low modulus coating is applied between the SiC-matrix composite and the protective coating.

A finite element analysis (FEA) has been successfully performed on two different geometries of alumina-coated $\mathrm{SiC}$ substrates (monolithic or composite). The first geometry was a $10 \mathrm{~mm}$ diameter by $40 \mathrm{~mm}$ long cylinder circumferentially coated with $100 \mu \mathrm{m}$ of alumina and the second was a $3 \mathrm{~mm}$ by $4 \mathrm{~mm}$ by $50 \mathrm{~mm}$ tensile specimen coated with $50 \mu \mathrm{m}$ of alumina on two opposite faces. Properties chosen for the two materials are shown in the table below:

\begin{tabular}{||l|c|c||}
\hline & Alumina & SiC \\
\hline Density $\left(\mathrm{gm} / \mathrm{cm}^{3}\right)$ & 3.900 & 3.200 \\
\hline Elastic Modulus $(\mathrm{GPa})$ & 372.0 & 455.0 \\
\hline Poisson's Ratio & 0.22 & 0.14 \\
\hline $\mathrm{CTE}\left(\mathrm{x} 10^{-6} /{ }^{\circ} \mathrm{C}\right)$ & 8.0 & 4.5 \\
\hline
\end{tabular}

Results of the FEA analysis revealed that the tensile stresses of $1.9 \mathrm{GPa}$ generated in the alumina coating are many times larger than its failure strength and will certainly result in cracked or spalled coatings. The calculated stresses in alumina coatings agreed with experimental evidence obtained in recent years. The compressive stresses set up in the SiC substrate are significant but are much lower than the compressive strength of the material. Obviously, alumina is not a good choice for coating of $\mathrm{SiC}$ because of the large thermal expansion mismatch between the substrate and coating but also because of the high elastic modulus of the alumina coating.

In order to reduce the stresses generated in the alumina coating, it has been proposed that a low-modulus compliant coating be deposited between the substrate and the alumina coating. A finite element analysis has been completed for a $\mathrm{SiC}$ substrate coated with a compliant layer followed by an alumina coating. The properties of the compliant layer considered in this exercise were a thickness of $50 \mu \mathrm{m}$, a modulus of $30 \mathrm{GPa}$, a CTE of $3.0 \times 10^{-6} /^{\circ} \mathrm{C}$, and a density of 3.3 $\mathrm{gm} / \mathrm{cm}^{3}$. The finite element analysis concluded that the incorporation of a compliant layer failed to significantly reduce the stresses in the protective alumina coating. The finite element analysis was repeated using a compliant layer thickness of $100 \mu \mathrm{m}$. Unfortunately, the stresses within the protective alumina coating were still not reduced significantly. 
The finite element results indicate that alumina is not a good choice for coating SiC substrates because of the high modulus (very brittle nature) of the coating. The apparent conclusion of the FEA is that a very strain tolerant, low-modulus, low-expanding material needs to identified for use a corrosion resistant coating. If the low-modulus, low-expansion coating could be applied at or above the use temperature, the stresses within the coating at lower temperatures during thermal cycling would always be compressive in nature. If alumina coatings would be required for additional corrosion protection, only very thin coatings could be expected to survive. 



\title{
2.3 DEVELOPMENT OF OXIDATION/CORROSION-RESISTANT COMPOSITE MATERIALS AND INTERFACES
}

\author{
D. P. Stinton, T. M. Besmann, S. Shanmugham, A. Bleier, E. Lara-Curzio
}

INTRODUCTION

Continuous fiber ceramic composites (CFCCs) are being developed for high temperature structural applications, many of which are in oxidative environments. ${ }^{1,2}$ Such composites are attractive since they are light-weight and possess the desired mechanical properties at elevated temperature and in aggressive environments. The most significant advantage is their toughness and their non-catastrophic failure behavior. 3,4

The mechanical properties of CFCCs have been characteristically linked with the nature of the interfacial bond between the fibers and the matrix. 5,6 Weakly bonded fiber-matrix interfaces allow an impinging matrix crack to be deflected such that the fracture process occurs through several stages: Crack deflection, debonding at the interface, fiber slip and pull-out, and ultimately fiber failure. ${ }^{7}$ Such a composite will fail in a graceful manner and exhibit substantial fracture toughness. Currently, carbon interface coatings are used to appropriately tailor interface properties, however their poor oxidation resistance has required a search of an appropriate replacment.

Generally, metal oxides are inherently stable to oxidation and possess thermal expansion coefficients relatively close to those of Nicalon and SiC. However, the metal oxides must also be chemically compatible with the fiber and matrix. If the fiber/interface/matrix system is chemically compatible, then the interfacial bonding stress is influenced by the thermal residual stresses that are generated as the composite is cooled from processing to room temperature. 
In the current work, thermomechanical computational results were obtained from a finite element model (FEM) for calculating the thermal residual stresses. ${ }^{8}$ This was followed by experimental evaluation of Nicalon/SiC composites with carbon, alumina, and mullite interfacial coatings.

\section{DISCUSSION OF CURRENT ACTIVITIES}

\section{Finite Element Modeling}

A finite element model has been developed in order to understand the effect of interfacial coating materials on the profile of thermal residual stresses. The elementary cell comprises a fiber (radius $=7 \mu \mathrm{m}$ ) surrounded by an interfacial coating, the matrix (radius $=11 \mu \mathrm{m}$ ) and the bulk material (Fig. 1). The bulk material is represented as having the average properties of the composite determined from the rule of mixtures. The fiber volume fraction is $40 \%$ and the interfacial and the matrix volume fraction varies with interfacial coating thickness.

The model is based on an axisymmetric system and the meshing was done with two dimensional elements (rectangular with eight nodes) in a plane. The boundary conditions are the following: 1, Displacement is permissible only along the axis of symmetry, 2 . the bottom of the cell can not be displaced in the direction of the axis of symmetry and the bulk cannot rotate around this axis and has its outer surface free, and 3. a temperature differential of $1175 \mathrm{~K}$ is assumed due to cooling from the processing temperature of $1473 \mathrm{~K}$. 


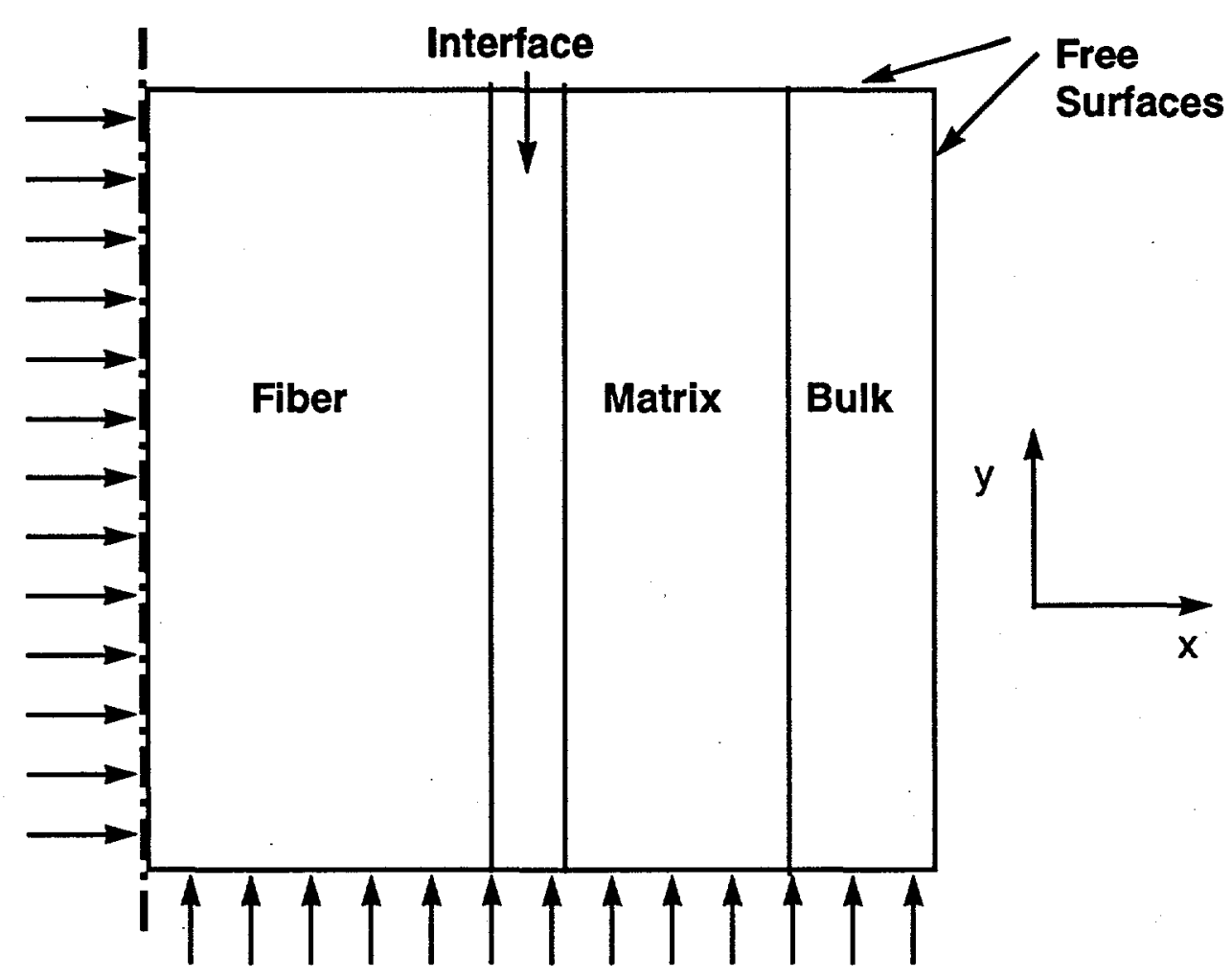

Fig. 1 Schematic of an elementary cell in the finite element model

A variety of potential interfacial coating materials (carbon, aluminum titanate, barium zirconium phospate silicate or BaZPS, alumina and mullite) which represent a wide range of mechanical properties (Young's modulus, coefficient of thermal expansion, and Poisson's ratio) were considered. The properties of Nicalon, $\mathrm{SiC}$ matrix, and the interfacial coating materials are summarized in Table 1. The finite element model was used to compute the effect of carbon coating thickness on the radial thermal residual stresses $\left(\sigma_{\mathrm{x}}\right)$ at the fiber-coating interface and the coating-matrix interface (Fig. 2). The residual radial stress for the fiber-matrix interface in the absence of any coating is based on Hsueh's 10 model. With a thin coating $(0.1 \mu \mathrm{m})$, the residual 
radial stresses at both of the interfaces are compressive, although they become tensile with increasing coating thickness. The effect of alternative coating materials with a thickness of $0.5 \mu \mathrm{m}$ on the radial stresses developed at the interfaces are shown in Fig. 3 and compared with that for $0.1 \mu \mathrm{m}$ carbon.

Table 1. Material properties utilized in the FEM analysis [9]

Material Young's modulus Coefficient of Poisson's ratio $\mathrm{E}(\mathrm{GPa})$ thermal expansion $\mathrm{v}$

\begin{tabular}{llllllllll} 
& \multicolumn{10}{c}{$\left(\mathrm{x} 10^{-6} / \mathrm{K}\right)$} \\
& $\mathrm{E}_{\mathrm{x}}$ & $\mathrm{E}_{\mathrm{y}}$ & $\mathrm{E}_{\mathrm{z}}$ & $\alpha_{\mathrm{x}}$ & $\alpha_{\mathrm{y}}$ & $\alpha_{\mathrm{z}}$ & $v_{\mathrm{x}}$ & $v_{\mathrm{y}}$ & $v_{\mathrm{z}}$ \\
Nicalon & 200 & 200 & 200 & 3 & 3 & 3 & .12 & .12 & .12 \\
$\mathrm{SiC}$ & 350 & 350 & 350 & 4.6 & 4.6 & 4.6 & .2 & .2 & .2 \\
Carbon & 12 & 40 & 40 & 28 & 2 & 2 & .4 & .12 & .12 \\
Alumina & 380 & 380 & 380 & 8.3 & 8.3 & 8.3 & .22 & .22 & .22 \\
Mullite & 220 & 220 & 220 & 5 & 5 & 5 & .27 & .27 & .27 \\
BaZPS with & & & & & &. & & & \\
x=0.25 & 50 & 50 & 50 & 1 & 1 & 1 & .2 & .2 & .2 \\
$\mathrm{Al}_{2} \mathrm{TiO}_{5}$ & 11 & 11 & 11 & 1 & 1 & 1 & .22 & .22 & .22
\end{tabular}

Based on the FEM results, among the three parameters, Young's modulus, coefficient of thermal expansion and Poisson's ratio, the Young's modulus plays a more dominant role. For example, as the modulus of the coating is decreased (e.g., from alumina to aluminum titanate) the difference in residual stresses that are generated at the fiber/interfacial coating and interfacial coat 


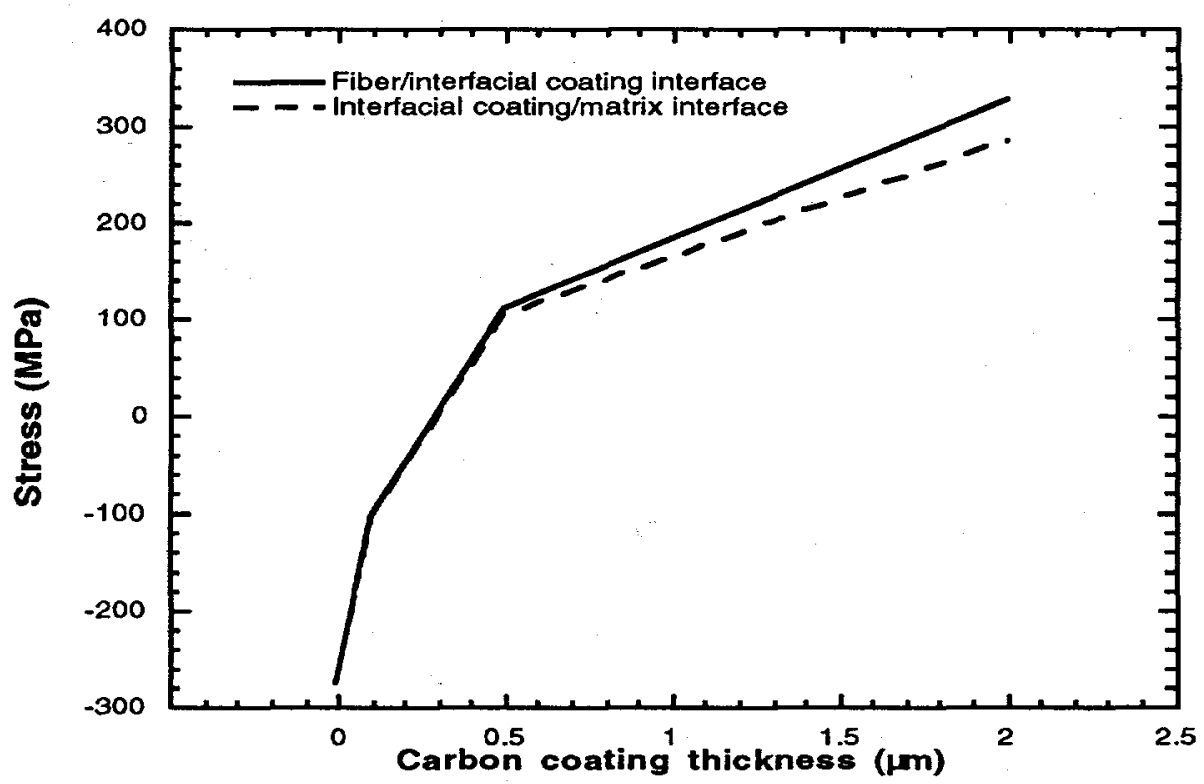

Fig. 2 Effect of carbon coating thickness on the calculated residual radial thermal stresses derived from the finite element model

ing/matrix interfaces are reduced (Fig. 3). Further, the materials with low Young's modulus (e.g., aluminum titanate) cause a reduction of compressive thermal residual stresses similar to that for the $0.1 \mu \mathrm{m}$ thick carbon coating. Moreover, for interfacial materials with the same modulus, a material with a higher thermal expansion coefficient than that of the fiber and matrix is more effective in reducing radial stresses than is a material with a lower or similar thermal expansion. Trends similar to those reported here were observed with Hsueh"s 10 model as well. 


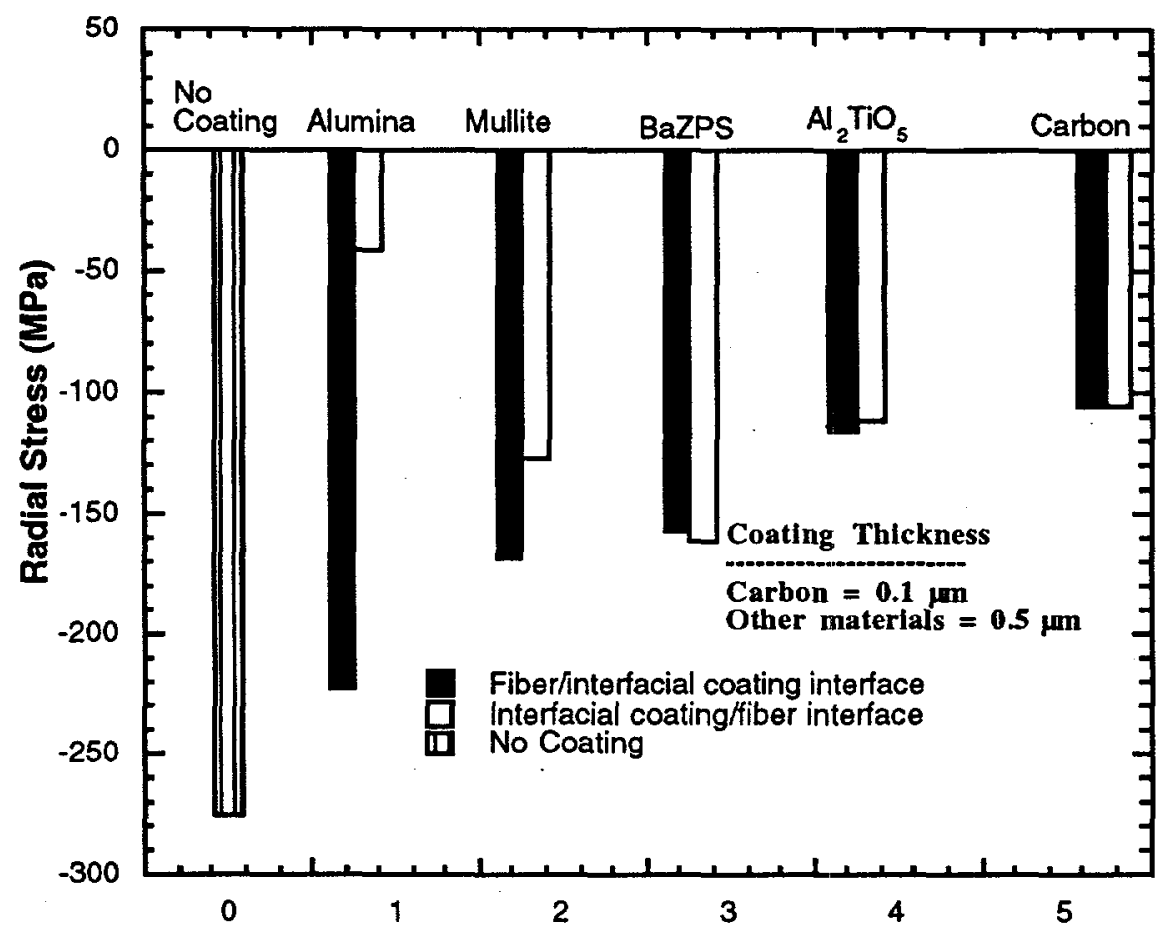

Fig. 3 Finite element computations indicate that low modulus interfacial coatings reduce compressive radial stresses

\section{Experimental Results}

Nicalon (Ceramic Grade Nicalon, Nippon Carbon Company, Tokyo, Japan) fibrous preforms were prepared by stacking multiple layers of plain weave Nicalon cloth in a $0 \pm 30$ sequence within the cavity of a graphite holder. The preform was compressed by hand and held within the graphite holder with a graphite lid. The cloth sizing was removed by heat treatment at $973 \mathrm{~K}$ in $\arg o n$ for $2 \mathrm{~h}$. The average fiber content of the resulting fiber preforms was 40 vol\% with sample dimensions of $45 \mathrm{~mm}$ in diameter and $12.25 \mathrm{~mm}$ in thickness. 
The carbon interfacial coating was deposited from a dilute argon/propylene mixture at $1373 \mathrm{~K}$ and $3 \mathrm{kPa}$ pressure. The alumina (Grade RCHP-DBM, Reynolds Aluminum,) and mullite (Baikowski International Corporation, North Carolina) interfacial coatings were applied starting from powders using a novel colloidal process developed at Oak Ridge National Laboratory. Preforms with alumina and mullite interfacial coatings were then sintered in argon at $1373 \mathrm{~K}$ for $2 \mathrm{~h}$.

The coated preforms were infiltrated with $\mathrm{SiC}$ matrix using the forced flow, thermal gadient chemical vapor infiltration (FCVI) process. ${ }^{2}$ The SiC matrix was deposited from the decomposition of methyltrichlorosilane (MTS) in hydrogen. The process parameters are as follows: Top surface temperature of $1473 \mathrm{~K}$; MTS flow of $0.307 \mathrm{~g} / \mathrm{min}$; hydrogen flow of $500 \mathrm{~cm} / \mathrm{min}$; and exhaust pressure of $101 \mathrm{kPa}$. Typically, the matrix infiltration was completed within 20 hours.

The infiltrated Nicalon/SiC composites were cut into twenty-four flexural bars of average size $2.5 \times 3.0 \times 40 \mathrm{~mm}$. The dimensions of the cut flexural bars were measured and they were weighed to determine densities. Half of the flexure bars were then heat treated at $1273 \mathrm{~K}$ for $24 \mathrm{~h}$ in air to determine their oxidation behavior. The bars were loaded perpendicular to the layers of the cloth and the fracture surfaces were examined by scanning electron microscopy.

Fracture surface examination of composites with carbon interfacial coatings showed considerable fiber pull-out before oxidation (Fig. 4a). However, after oxidation they exhibited brittle fracture with very little fiber pull-out (Fig. 4 b) due to the oxidation of the carbon interlayer and the subse- 
quent formation of silica that bonded the fibers to the matrix. ${ }^{5,11}$ The fracture surface of a composite with an alumina interfacial coating also showed very little fiber pull-out after oxidation (Fig. 5) and Langley et al. ${ }^{12}$ reported that the tensile strength of Nicalon fibers coated with alumina by plasma CVD were reduced by $30-40 \%$ compared to fibers simillarly coated with carbon. The fiber damage was attributed to either chemical reaction or mechanical damage resulting from the thermal expansion mismatch between fiber and coating, or a combination of both. Walukas ${ }^{13}$ observed that sol-gel derived alumina interfacial coating reacted with silica in the Nicalon fiber during composite densification to form mullite. The fracture surface of the composite with a mullite interfacial coating, however, displayed considerable fiber pull-out before and after oxidation (Fig. 6), however, the non-uniformity of coatings is a problem, and regions with considerable fiber-pull out are adjacent to regions of brittle fracture(Fig. 7). The accumulation of coating material around the fibers in certain areas also resulted in the lack of matrix in those areas. Preliminary thermodynamic calculations indicate that mullite coatings are likely to be stable with the Nicalon/SiC system.

In order to overcome the non-uniformity problem a sol-gel approach is being pursued to deposit mullite coatings. Mullite sols with yield of the oxides ranging from $1-5 \%$ were used for coating Nicalon fabric. The sizing on the nicalon was removed by heat treatment at $600^{\circ} \mathrm{C}$ for $1 \mathrm{~h}$. The Nicalon was coated just after the removal of the sizing and after pretreatment with alcohol as well. The fabric was dipped into the mullite sol and dried either in air or in the presence of saturated methanol solution. Several combinations were tried and it was found that mullite sols with $1 \mathrm{wt} \%$ yield and dried in the presence 
of saturated methanol solution produced the best coatings. Figures $8 \mathrm{a}$ and $8 \mathrm{~b}$ show the mullite coating on untreated Nicalon fabric after 1 and 3 dips, respectively and dried in air. Figure 9 shows the mullite coating on a Nicalon fabric pretreated in alcohol and dried in the presence of a saturated methanol solution. Coatings obtained under controlled drying conditions (Fig. 9) exhibited better uniformity than the coatings dried in air (Fig. 8).

\section{Conclusions}

FEM analysis revealed that a low modulus interfacial coating will be effective in reducing radial residual stresses that result from cooling from processing temperatures. Further, for the interfacial materials with the same modulus, a material with a higher thermal expansion coefficient than that of the fiber and matrix is more effective in reducing the radial stresses than is a material with a lower or similar thermal expansion coefficient.

Composites with carbon and alumina interfacial coatings exhibited brittle fracture after oxidation. However, a composite with a mullite interfacial coating retained considerable fiber pull-out, suggesting that it may be a desirable interfacial coating. Colloidal coating application, however, resulted in non-uniform mullite coatings. Potentially, the use of sol-gel methods may result in coatings with much better uniformity.

\section{REFERENCES}

1. N. Chawla, P. K. Liaw, E. Lara-Curzio, R. A. Lowden and M. K. Ferber, Symposium on "High Performance Composites," TMS, Warrendale, PA, K. K. Chawla, P. K. Liaw and S. G. Fishman, eds., 291, 1994.

2. T. M. Besmann, B. W. Sheldon, R. A. Lowden, and D. P. Stinton, Science, 
$253,1104,1991$.

3. D. P. Stinton, A. J. Caputo, and R. A. Lowden, Am. Ceram. Soc. Bull., 65 (2), 347, 1986. 4. K. M. Prewo and J. J. Brennan, J. Mater. Sci., 15, 463, 1980. 5. A. G. Evans and D. B. Marshall, in Fiber Reinforced Ceramic Composites: Materials, Processing and Technology, ed. by K. S. Mazdiyasni, Noyes Publications, Park Ridge, NJ, 1, 1990.

6. D. B. Marshall and A. G. Evans, J. Amer. Ceram. Soc., 68 (5), 225, 1985.

7. R. W. Rice, Ceram. Eng. Sc. Proc., 2 (7-8), 661, 1981.

8. F. Rebillat, Unpublished work

9. Engineered Materials Handbook, Vol. 4, Ceramics and Glasses, ASM International, 1991.

10. C. H. Hsueh, P. F. Becher, and P. Angelini, J. Am. Ceram. Soc., 71 (11), $929,1988$.

11. B. A. Bender et al., Ceramic Eng. Sci. Proc., 5 (7-8), 614, 1984.

12. N. R. Langley et al., in Metal Matrix, Carbon and Ceramic matrix Composites,, ed. by J. D. Buckley, 1987.

13. D. M. Walukus, A Study of the Mechanical Properties and Oxidation Resistance of Nicalon-SiC composites With Sol-Gel-Derived Oxide Interfacial Coatings, M. S. Thesis, University of Tennessee, May 1993.


Fig. 4 Fracture surface of a composite with carbon interfacial coating (a) before oxidation and (b) after oxidation in air for $24 \mathrm{~h}$ at $1273 \mathrm{~K}$ 

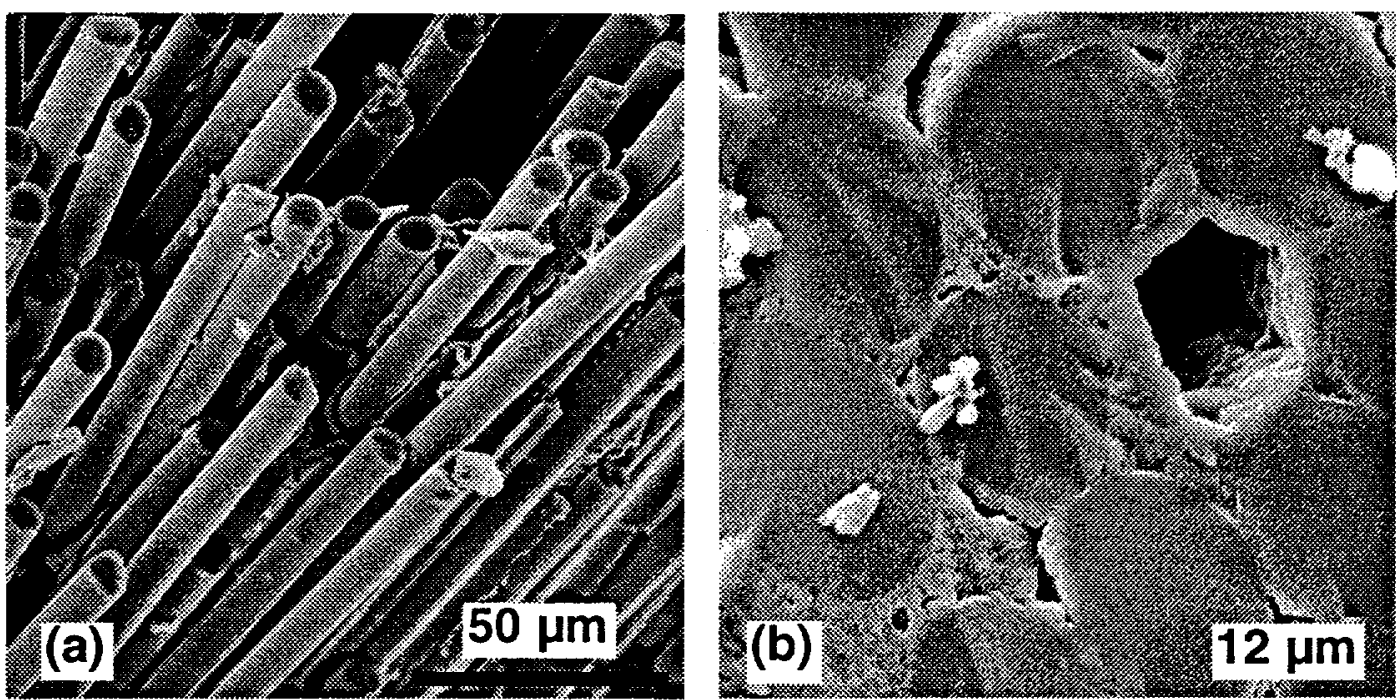

Fig. 5 Fracture surface of a composite with an alumina interfacial coating (a) before oxidation and (b) after oxidation in air for $24 \mathrm{~h}$ at $1273 \mathrm{~K}$
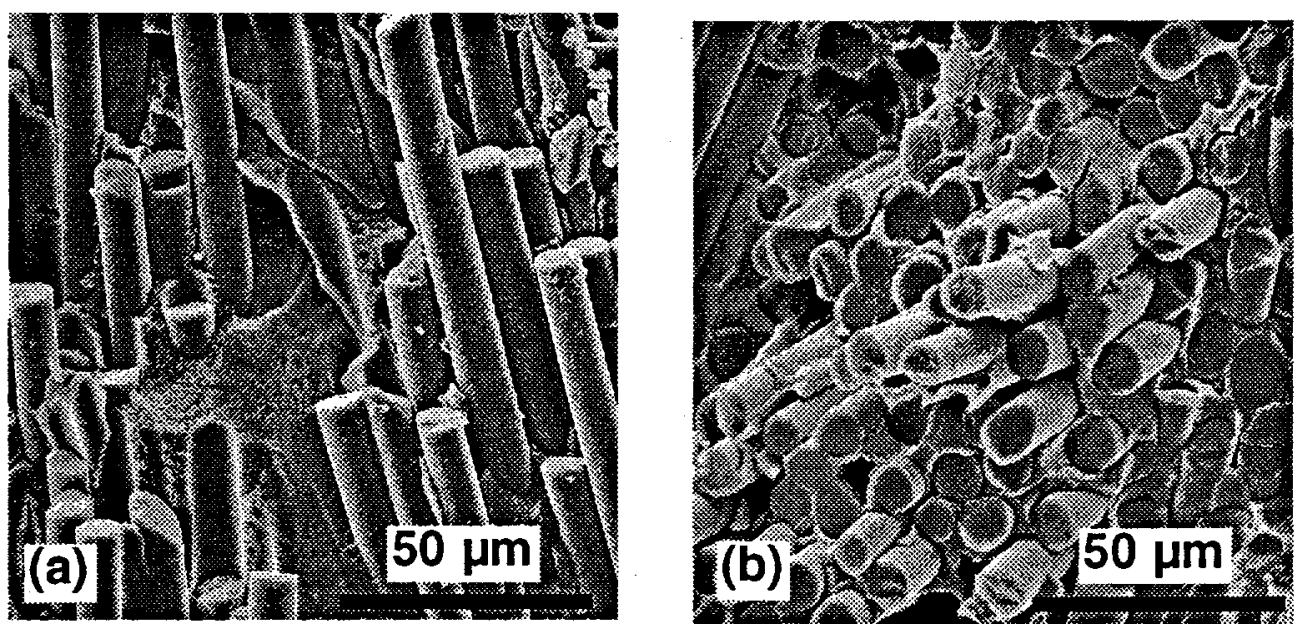

Fig. 6 Fracture surface of a composite with a mullite interfacial coating (a) before oxidation and (b) after oxidation in air for $24 \mathrm{~h}$ at $1273 \mathrm{~K}$ 


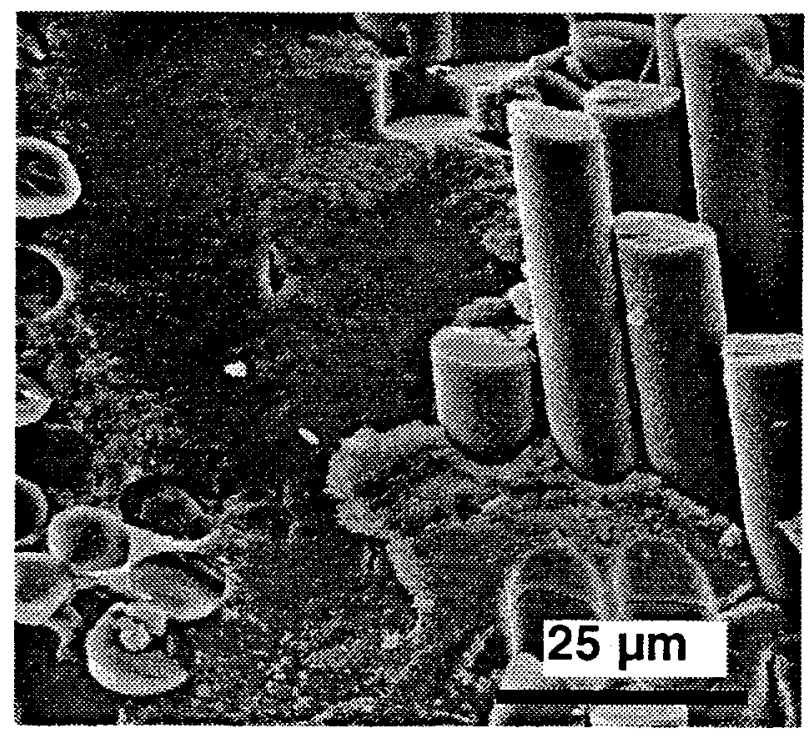

Fig. 7 Non-uniformity of the mulliteinterfacial coating resulted in fiber pullout in certain regions and brittle fracture in other areas
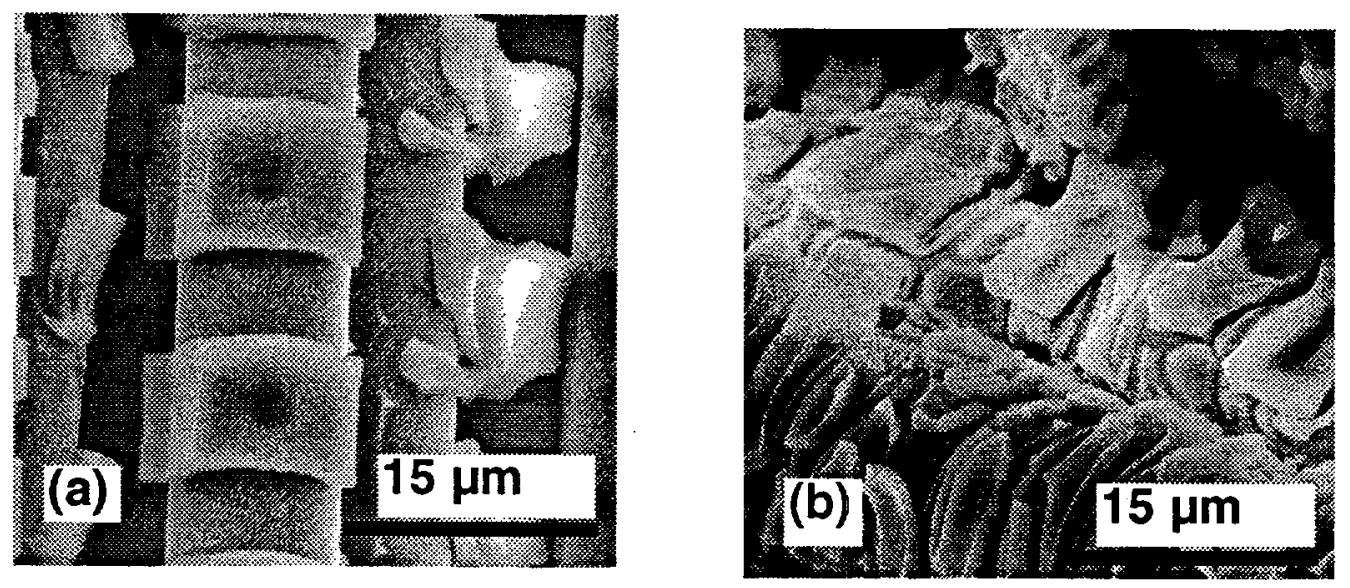

Fig. 8 Mullite coating on the untreated Nicalon fabric (a) after 1 dip and (b) after 3 dips 


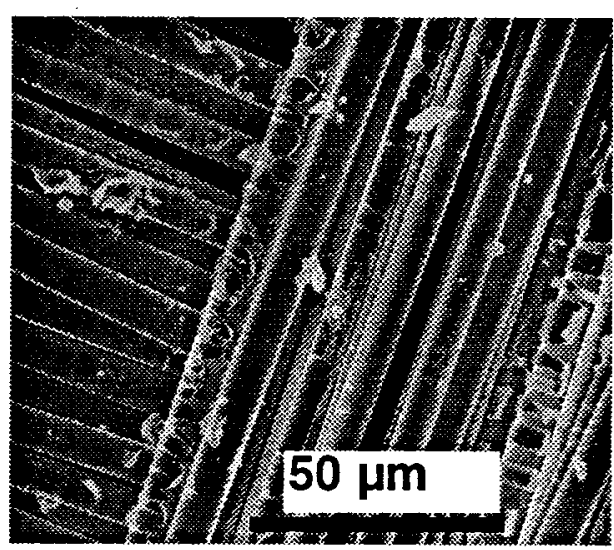

Fig.9 Mullite coating on Nicalon fabric after pretreatment with alcohol and dried in the presence of a saturated methanol solution 



\subsection{DEVELOPMENT OF MICROWAVE-HEATED DIESEL PARTICULATE FILTERS}

Mark A. Janney and David P. Stinton

oak Ridge National Laboratory

Oak Ridge, Tennessee 37831-6087

\section{ABSTRACT}

Ceramic fiber filters are being fabricated and tested for use as diesel particulate filters. The filters are to be heated by microwave energy to remove carbon and regenerate the filters.

\section{INTRODUCTION}

The purpose of this research is to help develop microwave-heated diesel engine particulate filter/burner devices. The goal is to develop materials that will perform both as filter and heater in such a device. A Cooperative Research and Development Agreement (CRADA No. ORNL93-0172) between Martin Marietta Energy Systems (MMES) and the Cummins Engine Company is in place that supports this, work. The Department of Energy (DOE) CRADA monies come from both the Fossil Energy AR\&TD Materials Program and the Energy Efficiency and Renewable Energy - Office of Transportation Technologies (EE-OTT), Heavy Duty Transport Program.

Diesel engines will soon be required (1998) to emit essentially no particulate exhaust into the environment. One of the approaches to prevent such emissions is to trap the particles in a filter, then burn the trapped particles on a regular cycle. An approach that has been proposed by Cummins Engine Co. is to build a system based on a ceramic filter that can be heated with microwaves. We will fabricate such filters 
and determine how they interact with microwaves to heat and burn the carbon particulates trapped in the filter material.

We propose to develop a ceramic composite structure of Sic-coated ceramic fiber that can be used as a diesel engine particulate filter. For commercial usage a particulate filter must: 1) filter carbon particles from high temperature diesel exhaust gas at an acceptable (low) backpressure; 2) survive thousands of thermal transients caused by regeneration (cleaning) of the filter by oxidizing the collected carbon; be durable and reliable over the life of the filter, which is in excess of 300,000 miles $(10,000$ hours of operation); and, (4) provide a low overall operating cost which is competitive with other filtering techniques.

SiC-coated ceramic fiber was selected as the filter material because it can be readily heated by microwave energy. Particulate traps must be regenerated by heating the carbon particles to approximately $600^{\circ} \mathrm{C}$ to oxidize the carbon. Heating by microwaves is expected to provide more uniform heating of the filter and result in a lower cost, more reliable regeneration system. Previous methods of regeneration used diesel-fired burners or electrical resistance heating for regeneration. Uneven heating and use of weak ceramic materials resulted in cracking of the trap and loss of filtration capability. Fiber composites have excellent thermal shock capability. Producing a filter by manufacturing a Eiber-reinforced ceramic paper has inherent advantages since it is possible to tailor the filtration characteristics of the ceramic paper while maintaining a strain tolerant material.

The idea of using microwave heating combined with ceramic filters to trap and burn carbon particulate emissions from 
diesel engines represents a large-scale, near term consumer and industrial application of two technologies, microwave heating and chemical vapor infiltration, developed under the AR\&TD materials program. As such, it has the potential to be an excellent example of technology transfer and cooperative research and development between a national laboratory and U.S. industry. This approach represents the front runner in the thinking of one of the nation's foremost diesel manufacturers.

\section{TECHNICAL PROGRESS}

- We are investigating the development of materials for diesel particulate filters. We have devoted our efforts to evaluating various candidate materials concerning: (1) how well they can be fabricated into filter elements; (2) how they interact with a microwave field - i.e., how they heat; ; and, (3) how well they withstand a corrosive (oxidative) high temperature environment.

\section{CVD Coating}

Filter papers made from ceramic fibers were received from Fleetguard, a division of Cummins Engine Company. These papers were coated at ORNL with CVI SiC containing various levels of additives. It had been observed last year that CVD conditions that should have produced high-quality, stoichiometric Sic coatings instead produced poor coatings. It was hypothesized that excess carbon had formed in the filter papers during pyrolysis of the organic constituents used in the papermaking process. Excess silicon was added to some of the CVI runs to compensate for the residual carbon. Figure 1 shows microstructures of the CVD-coated papers made under stoichiometric and excess silicon CVD conditions. Clearly, the coating made 
with excess silicon is superior to that made under stoichiometric conditions.

\section{Characterization of Filter Materials}

The various filter materials made above were tested under long term oxidation conditions $\left(500 \mathrm{~h}, 800^{\circ} \mathrm{C}\right)$. Figure 2 shows that the samples with coatings containing excess silicon performed the best. They exhibited only a small change in weight, losing weight in the short term, and gaining slightly in the long term. This behavior is consistent with the fibers being coated by a dense, adherent silicon carbide coating.

Filter materials were also characterized in terms of their microwave absorption properties. Figure 3 shows the behavior of a typical sample that had been coated with CVD silicon carbide under "stoichiometric" conditions. The initial properties of the sample showed that it absorbed microwaves very strongly at ambient temperature. Its penetration depth (see below) was on the order of $1 \mathrm{~cm}$. On heating the first time, the properties of the material changed dramatically. At about $600^{\circ} \mathrm{C}$, the sample became much less absorptive and its penetration depth increased by a factor of 10 , and then fell again as temperature was further increased. Upon a second heating, the sample behaved very differently. Its penetration depth at ambient temperature was about $1000 \mathrm{~cm}$. This value decreased with increasing temperature and at $700^{\circ} \mathrm{C}$ matched the values obtained during the first heating. There were no additional changed in microwave properties with additional heatings $(3,4$, and 5$)$.

The drastic changes in microwave absorption (penetration depth) during the first heating is consistent with burnout of 
carbon in the sample. The semilog relationship of penetration depth with temperature during cycles 2 though 5 is consistent with the exponential increase in the electrical conductivity of silicon carbide with increasing temperature.

\section{Penetration Depth and Applicator Design}

Microwaves are absorbed in materials according to the Beer-Lambert Law:

$$
P=P_{0} \exp (-\alpha X)
$$

where $\mathrm{P}$ is the power at any point, $\mathrm{P}_{\circ}$ is the incident power, $\alpha$ is the absorption coefficient, and $\mathrm{X}$ is the distance of penetration into the material. The absorption coefficient, $\alpha$, is related to more fundamental properties:

$$
\alpha=\left(\omega \sqrt{\left.e^{\prime} r \tan \delta\right) / \mathrm{c}}\right.
$$

where $\omega=$ frequency, $e^{\prime} r=$ relative dielectric constant, $\tan \delta=$ dielectric loss tangent, and $c=$ speed of light. One may define a characteristic distance, called the penetration depth, which is related to the absorption coefficient. The penetration depth is defined as the distance into the material at which the incident energy has been reduced by a factor of $1 / e$ (where $e=2.7183$, the base of the natural logarithms). Figure 4 shows this relationship graphically.

The importance of penetration depth (absorption coefficient) as a design parameter is shown in Figure 5. This figure shows a simplified design for a microwave filter heater. For a material having a very large absorption coefficient (small penetration depth), $\alpha r>1$ and all of the microwave energy is deposited at the outer surface of the filter. For very small 
absorption coefficients (large penetration depths), $\alpha r \ll 1$ and the microwave energy is absorbed very slowly by the filter material. Standing waves build up inside the applicator, which lead to "hot spots" and "cold spots" in the filter. For moderate absorption coefficients (moderate penetration depths), $\alpha r \approx 1$; most of the microwave energy is absorbed in one or two passes through the filter. This leads to the most uniform heating of the filter by the microwaves. The penetration depths of the materials being developed in this study range from 10 to $1000 \mathrm{~cm}$ for an individual layer of CVD coated filter material. The actual filters will contain multiple layers of filter material. This will produce a composite having a penetration depth that is of the order of the size of the microwave applicator, i.e., 10 to $20 \mathrm{~cm}$.

\section{System Testing}

In February 1995, a prototype filter cartridge was tested at Cummins Engine Company in a developmental microwave applicator as a first proof-of-concept test for the microwave regenerated filter. The filter removed carbon particles from the exhaust of a test diesel engine and the microwave heater successfully regenerated the filter by burning out the carbon. 


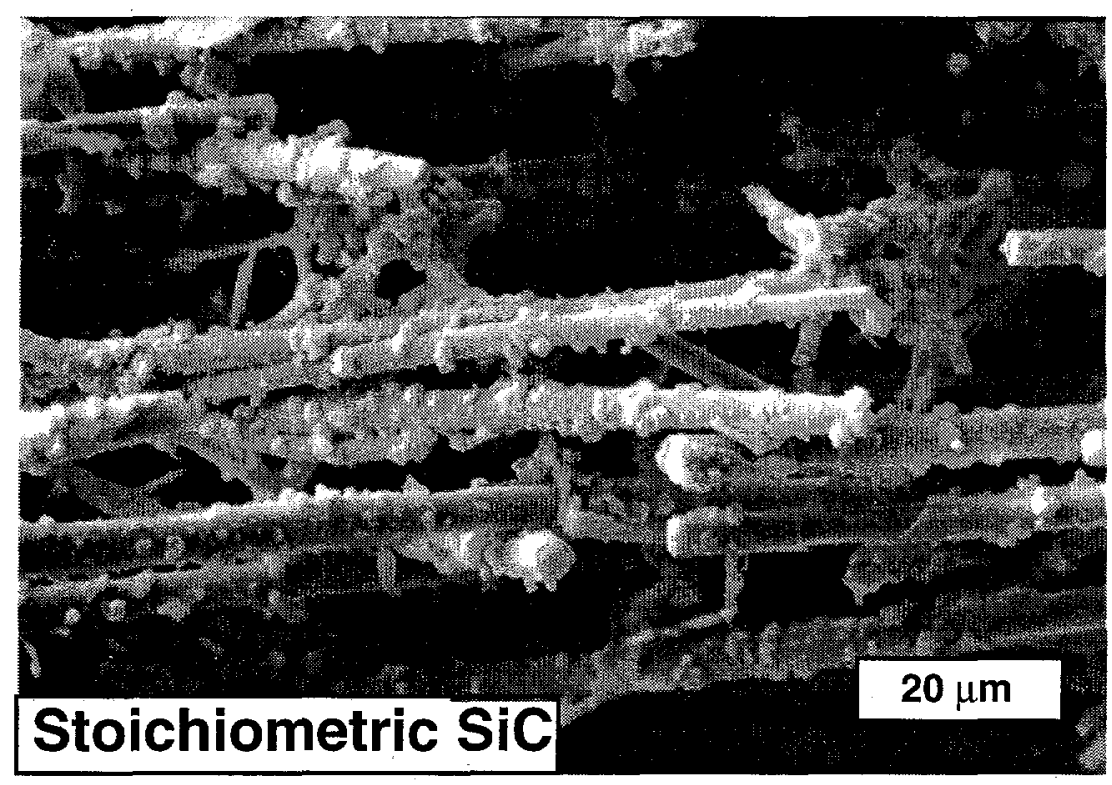

(a)

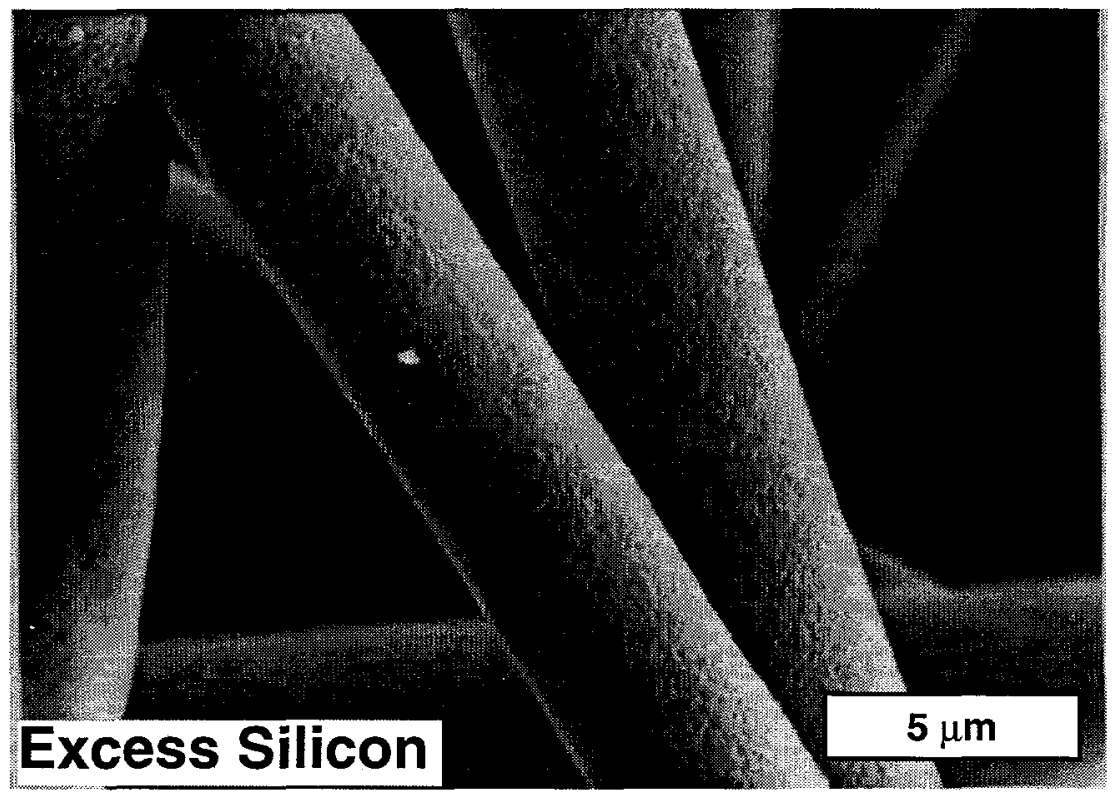

(b)

Figure 1. The addition of excess silicon to the CVI coating on the filter preforms produced a superior coating: (a) stoichiometric SiC; (b) excess silicon. SEM micrographs. 


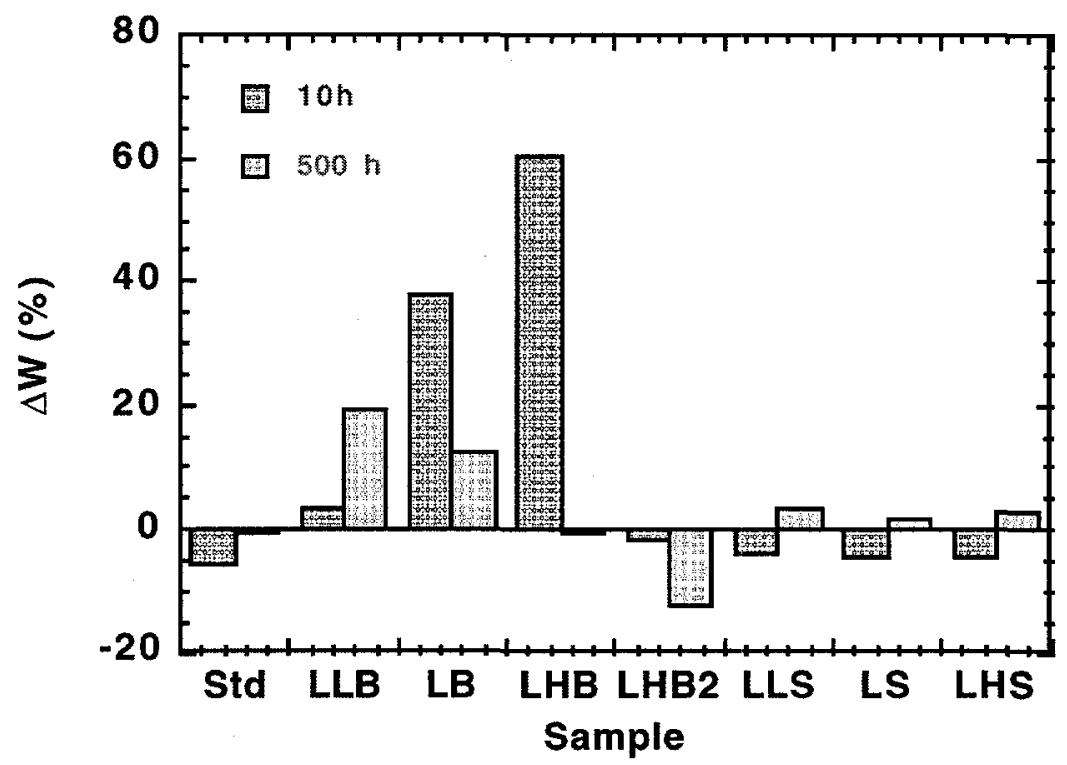

Figure 2. Samples containing excess silicon in the CVI coating were the most resistant to oxidation.

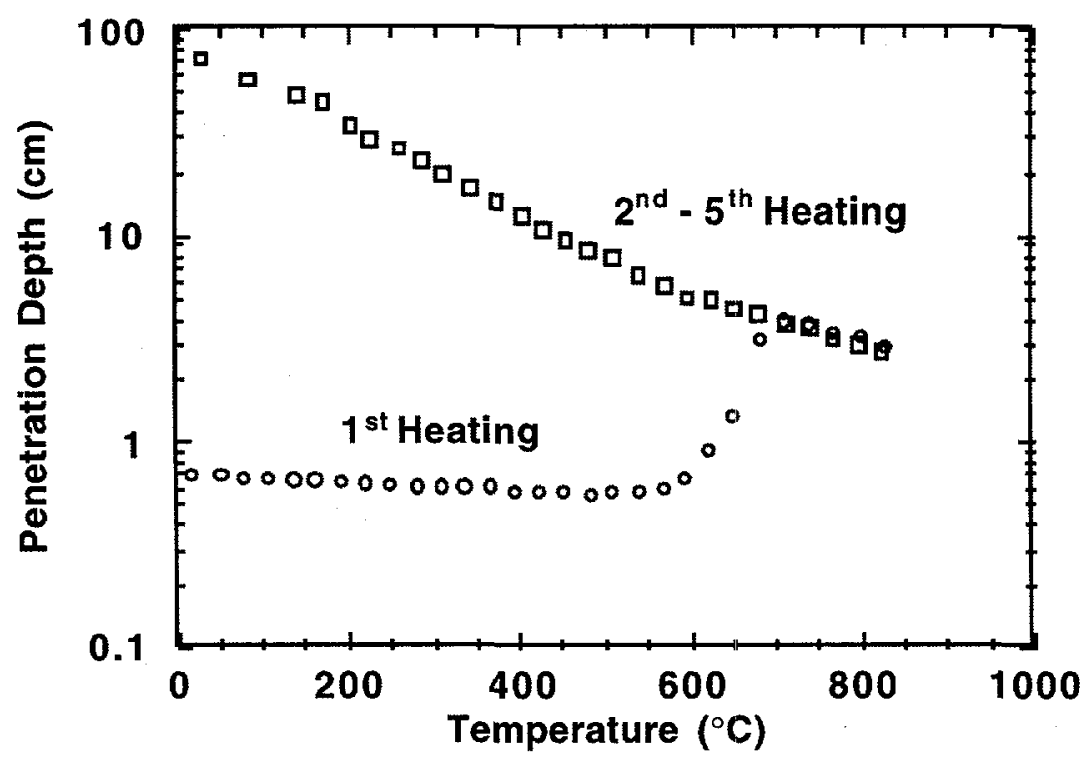

Figure 3. Sic coated alumina fiber filter materials "aged" on first heating. They were stable on subsequent heating. Filter coated with "stoichiometric" SiC CVI mixture. 


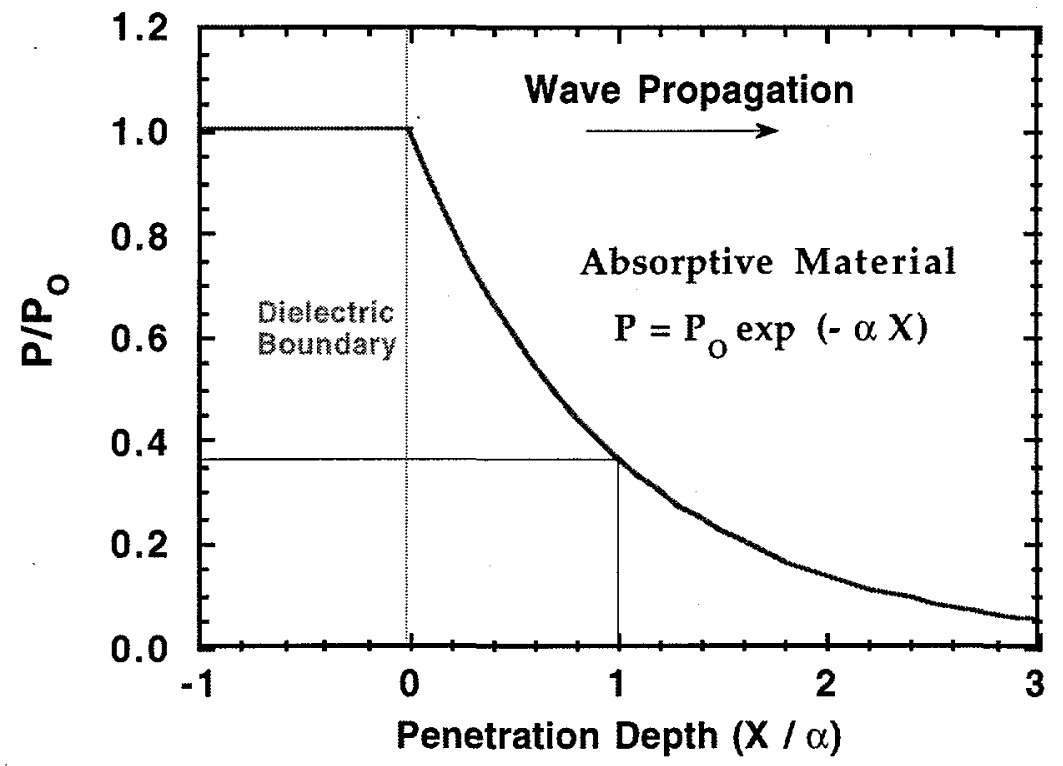

Figure 4. Most of the power in a microwave beam is lost in the first penetration depth.

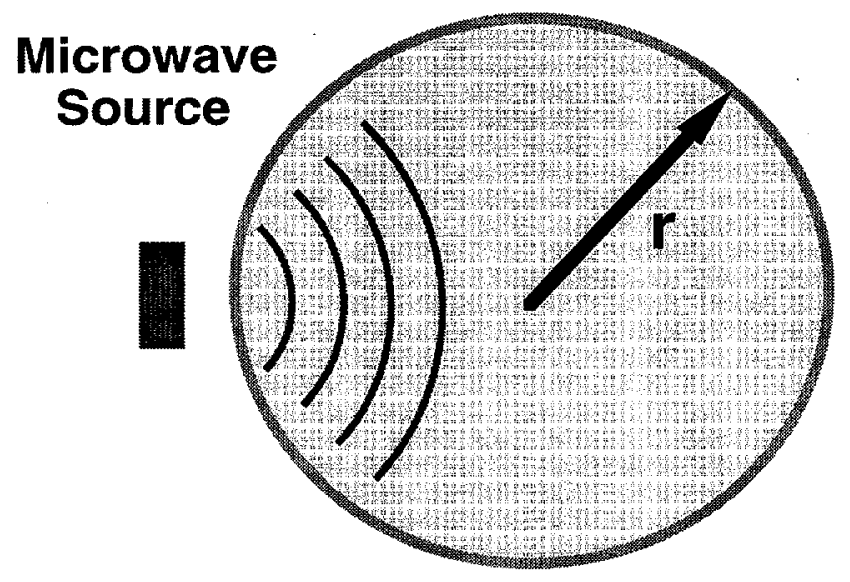

Filter Cartridge

Figure 5. Penetration depth is an important factor in developing a microwave applicator the heats uniformly. 



\title{
2.5 A NOVEL CARBON FIBER BASED POROUS CARBON MONOLITH
}

\author{
T. D. Burchell, J. W. Klett, and C. E. Weaver
}

\section{INTRODUCTION}

A novel porous carbon material based on carbon fibers has been developed. The material, when activated, develops a significant micro- or mesopore volume dependent upon the carbon fiber type utilized (isotropic pitch or polyacrylonitrile). The materials will find applications in the field of fluid separations or aa a catalyst support. Here, the manufacture and characterization of our porous carbon monoliths are described.

A novel adsorbent carbon composite material has been developed ${ }^{1,2}$ comprising carbon fibers and a binder. The material, called carbon fiber composite molecular sieve (CFCMS), was developed through a joint research program between Oak Ridge National Laboratory (ORNL) and the University of Kentucky, Center for Applied Energy Research (UKCAER).

The materials are manufactured from milled carbon fibers and powdered phenolic resin, which are slurried in water and vacuum molded. The molding process allows the manufacture of slabs, tubes or more complex geometries with contoured surfaces. The "green" (as molded) artifact is heated at $130^{\circ} \mathrm{C}$ to cure the phenolic resin and then carbonized at $650^{\circ} \mathrm{C}$. The resultant monoliths have bulk densities in the range $0.2-0.4 \mathrm{~g} / \mathrm{cm}^{3}$ and crush strength of $1-2 \mathrm{MPa}$. Two carbon fiber types have been utilized in our work to date. First, petroleum-pitch derived isotropic carbon fibers have been fabricated into monoliths and activated in steam or $\mathrm{CO}_{2}$ at $850^{\circ} \mathrm{C}$. The material develops significant microporosity, with mean pore sizes in the range $0.5-1.0 \mathrm{~nm}$, and micropore volumes in the range $0.2-0.5 \mathrm{~cm}^{3} / \mathrm{g}$. Second, monoliths have been manufactured from polyacrylonitrile (PAN) derived carbon fibers. These materials develop significant mesoporosity in the size range $2-50 \mathrm{~nm}$ and mesopore volumes typically exceeding $0.5 \mathrm{~cm}^{3} / \mathrm{g}$, making them potential catalyst support materials. In both cases the composites are strong and porous, allowing fluids to easily flow through the material.

The isotropic pitch derived carbon fiber porous carbon monolith, when activated, provides a high micropore surface area $\left(>1900 \mathrm{~m}^{2} / \mathrm{g}\right.$ ) capable of rapid adsorption and desorption. The activated fiber micropore distribution is very narrow, with mean micropore sizes $<1 \mathrm{~nm}$, allowing molecular 
sieving on the basis of molecular size and shape. A potentially large application for our carbon-fiber based porous monoliths is gas separation using the Pressure Swing Adsorption (PSA) process.

Separation by adsorption is based on the selective accumulation of one or more components of a gas mixture on the surface of a microporous solid. When a gaseous mixture is exposed to an absorbent for sufficient time, an equilibrium is established between the adsorbed phase and the gas phase. The gas phase becomes richer in the less selectively adsorbed component. The attractive forces responsible for adsorption are of the Van der Waals type. Desorption can be achieved either by increasing the temperature of the system or by reducing the adsorbate pressure. The desorption step also regenerates the adsorbent surface for reuse during the subsequent adsorption step. Thus, the adsorptive separation process consists of a cyclic sequence of adsorption and desorption steps. When desorption is achieved by decreasing the pressure, the process is called pressure swing adsorption. One of the components of a gas mixture is selectively adsorbed at higher partial pressure and desorbed subsequently by lowering the partial pressure. The change in partial pressure of the component gas can be caused either by decreasing the total pressure, changing the composition of the gaseous mixture, or by a combination of both.

Here we report the synthesis and characterization of CFCMS material, particularly with respect to micropore and mesopore structure. Moreover, the results of $\mathrm{CO}_{2}$ uptake studies on microporous monoliths are reported.

\section{EXPERIMENTAL}

Nitrogen adsorption isotherms were measured at $77 \mathrm{~K}$ using our Autosorb-1 instrument. Micropore size analysis used a variety of methods, including the Brunauer, Emmett and Teller ${ }^{3}$ (BET) method for surface area and the Dubinin-Redushkevich (DR) method for micropore volume and micropore size. Additional micropore size estimates were obtained using the Horvath-Kawazoe (HK) and Dubinin-Astakhov (DA) methods. Mesopore $(2-50 \mathrm{~nm})$ and macropore $(>50 \mathrm{~nm})$ size, area, and volume data were obtained using a Micromeritics Autopore II mercury intrusion apparatus. Intrusion measurements were performed over the pressure range vacuum $(\sim 10 \mu \mathrm{m} \mathrm{Hg})$ to 90,000 psia. Equilibration times of 10 and 60 seconds were used for the low and high pressure measurements, respectively. CFCMS materials were subjected to microstructural examination using an ISI SS40 scanning electron microscope (SEM). $\mathrm{CO}_{2}$ uptake was measured using a Mettler thermal microbalance. Specimens were thoroughly outgassed by heating them to $300^{\circ} \mathrm{C}$ under vacuum on the 
microbalance. The specimens were then cooled under vacuum to room temperature and the balance back-filled with $\mathrm{CO}_{2}$. The weight loss and gain was measured when the specimen temperature was swung from 30 to $110^{\circ} \mathrm{C}$ and back to $30^{\circ} \mathrm{C}$.

\section{RESULTS AND DISCUSSION}

\section{CFCMS Synthesis}

The CFCMS material was fabricated at ORNL using a process initially developed by the DOE for the production of thermal insulators for NASA space missions ${ }^{4}$. Carbon fibers derived from either isotropic petroleum pitch, or PAN, were mixed in a water slurry with powdered phenolic resin. The slurry was transferred to a molding tank and the water drawn through a porous mold under vacuum. The resulting green artifact was dried, cured in air at $60^{\circ} \mathrm{C}$, and stripped from the mold. The composite was cured at $\sim 150^{\circ} \mathrm{C}$ in air prior to carbonization at $650^{\circ} \mathrm{C}$ under an inert gas. The CFCMS synthesis route is illustrated in Fig. 1. A schematic diagram of the molding arrangement is shown in Fig. 2. The fabrication process allows the manufacture of slab or tubular forms. Moreover, we believe that it will be possible to mold contoured plates, and tubes, to near net shape via this synthesis route. Once carbonized, CFCMS is readily machined to more complex geometries. Typical carbonized bulk densities of our CFCMS materials are $0.3-0.4 \mathrm{~g} / \mathrm{cm}^{3}$.

\section{Characterization}

\section{Microporous Carbon Fiber Monoliths}

Figure 3 ( $\times 200$ magnification) shows the structure of our CFCMS material manufactured from isotropic pitch derived carbon fibers. The chopped fibers are bonded at their contact points. The carbon fibers are approximately $10-20 \mu \mathrm{m}$ diameter, whereas the macro-voids between the fibers are typically $>30 \mu \mathrm{m}$ in size. The resultant open structure allows free flow of fluids through the material and ready access to the carbon fiber surface. Previously, we reported the carbon fiber length distribution ${ }^{1}$. 
The distribution mode is $\sim 400 \mu \mathrm{m}$ and the fiber lengths are widely distributed and range from 100 to $1000 \mu \mathrm{m}$. Mercury porosimetry data for the CFCMS material in the unactivated condition are shown in Fig. 4, and indicate the macropore size range to be approximately $10-100 \mu \mathrm{m}$. The macropores are the voids between the fibers, and mercury porosimetry data for macropore sizes are in agreement with visual observations made from SEM images (Fig. 3).

A series of CFCMS materials were prepared at ORNL and activated at UKCAER. Details of the activation conditions are given in Fable 1 along with the results of our analysis of the microporosity.

Table 1. Activation conditions and micropore characterization data.

\begin{tabular}{|c|c|c|c|c|c|c|c|c|c|}
\hline \multirow{3}{*}{$\begin{array}{l}\text { Spec. } \\
\text { Ident. }\end{array}$} & \multicolumn{4}{|c|}{ Activation Conditions } & \multicolumn{5}{|c|}{ Micropore Analysis Data } \\
\hline & \multirow{2}{*}{$\begin{array}{c}\text { Temp } \\
\left({ }^{\circ} \mathrm{C}\right)\end{array}$} & \multirow{2}{*}{$\begin{array}{c}\text { Time } \\
\text { (mins) }\end{array}$} & \multirow[b]{2}{*}{ Agent } & \multirow{2}{*}{$\begin{array}{c}\text { Burn- } \\
\text { off } \\
(\%)\end{array}$} & \multirow{2}{*}{$\begin{array}{c}\text { BET } \\
\text { Area } \\
\left(\mathrm{m}^{2} / \mathrm{g}\right)\end{array}$} & \multicolumn{3}{|c|}{ Micropore Width (nm) } & \multirow{2}{*}{$\begin{array}{c}\text { DR } \\
\text { Pore } \\
\text { Vol } \\
\left(\mathrm{cm}^{3} / \mathrm{g}\right)\end{array}$} \\
\hline & & & & & & HK & $\mathrm{DA}$ & $\mathrm{DR}$ & \\
\hline 160 & 800 & 30 & $\mathrm{H}_{2} \mathrm{O}$ & 7 & 394 & 0.48 & 1.3 & 0.58 & 0.20 \\
\hline $161 \mathrm{~A}$ & 950 & 10 & $\mathrm{CO}_{2}$ & 6 & 292 & 0.48 & 1.8 & 1.21 & 0.13 \\
\hline $161 \mathrm{~B}$ & 950 & 10 & $\mathrm{CO}_{2}$ & 6 & 281 & 0.47 & 1.9 & 1.34 & 0.10 \\
\hline 166 & 800 & 180 & $\mathrm{H}_{2} \mathrm{O}$ & 17 & 762 & 0.48 & 1.48 & 0.75 & 0.39 \\
\hline 167 & 800 & 360 & $\mathrm{H}_{2} \mathrm{O}$ & 28 & 891 & 0.49 & 1.5 & 0.76 & 0.49 \\
\hline 170 & 950 & 180 & $\mathrm{CO}_{2}$ & 32 & $\begin{array}{l}1132 \\
1038\end{array}$ & 0.47 & 1.6 & $\begin{array}{l}0.78 \\
0.76\end{array}$ & 0.48 \\
\hline 46 & 850 & 90 & $\mathrm{H}_{2} \mathrm{O}$ & 28 & 1461 & 0.62 & 1.3 & 0.67 & 0.73 \\
\hline
\end{tabular}

The BET surface areas reported in Table 1 ranged from 281 to $1461 \mathrm{~m}^{2} / \mathrm{g}$, and the mean micropore size (DR method) varied from $0.58-1.34 \mathrm{~nm}$. Moreover, the micropore volumes (DR method) varied from $0.1-0.73 \mathrm{~cm}^{3} / \mathrm{g}$. The large surface area, combined with a large volume of micropores, suggests these materials might have a strong affinity for the adsorption of light gases. Therefore, $\mathrm{CO}_{2}$ adsorption studies were performed, and our data are reported in Table 2.

Large $\mathrm{CO}_{2}$ uptakes were measured for the CFCMS samples. As a comparison a commercial coconut shell carbon was evaluated, and was shown to have adsorbed $\sim 20 \%$ less $\mathrm{CO}_{2}$ than our best 
CFCMS. Moreover, the adsorption process was significantly slower in the case of the coconut shell carbon, where resorption of the $\mathrm{CO}_{2}$ on cooling from the temperature swing took $>2$ hours compared with $<1$ hour for the CFCMS materials. The superior adsorption kinetics of the CFCMS are ascribed to the small diameter of the carbon fibers $(10-20 \mu \mathrm{m})$ compared to the $\sim 2-3 \mathrm{~mm}$ of the coconut shell carbon. The diffusion path for the $\mathrm{CO}^{2}$, to an adsorption site is, therefore, substantially shorter in

Table 2. $\mathrm{CO}_{2}$ uptake data and micropore data

\begin{tabular}{|c|c|c|c|c|c|c|c|c|c|}
\hline \multirow{3}{*}{$\begin{array}{l}\text { Spec. } \\
\text { Ident. }\end{array}$} & \multicolumn{4}{|c|}{$\mathrm{CO}_{2}$ Uptake data } & \multicolumn{5}{|c|}{ Micropore Analysis Data } \\
\hline & \multirow{2}{*}{$\begin{array}{c}\text { Sample } \\
\text { Mass } \\
(\mathrm{mg})\end{array}$} & \multirow{2}{*}{$\begin{array}{c}\mathrm{Wt} \% \\
\mathrm{CO}_{2} \\
\text { Uptake }\end{array}$} & \multirow{2}{*}{$\begin{array}{l}\text { Vol } \\
\mathrm{CO}_{2} \\
\mathrm{Ads} . \\
\left(\mathrm{cm}^{3}\right)\end{array}$} & \multirow{2}{*}{$\begin{array}{c}\text { Spec. } \\
\mathrm{CO}_{2} \text { Ads. } \\
\text { Capacity } \\
\left(\mathrm{cm}^{3} / \mathrm{g}\right)\end{array}$} & \multirow{2}{*}{$\begin{array}{l}\text { BET } \\
\text { Surf. } \\
\text { Area } \\
\left(\mathrm{m}^{2} / \mathrm{g}\right)\end{array}$} & \multicolumn{3}{|c|}{$\begin{array}{l}\text { Micropore Width } \\
\text { (nm) }\end{array}$} & \multirow{2}{*}{$\begin{array}{c}\text { DR } \\
\text { Pore } \\
\text { Vol } \\
\left(\mathrm{cm}^{3} / \mathrm{g}\right) \\
\end{array}$} \\
\hline & & & & & & $\mathrm{HK}$ & $\mathrm{DA}$ & $\mathrm{DR}$ & \\
\hline 160 & 89.50 & 7.8 & 3.95 & 44 & 394 & 0.48 & 1.3 & 0.58 & 0.20 \\
\hline 161 & 72.45 & 6.9 & 2.53 & 35 & 292 & 0.48 & 1.8 & 1.21 & 0.13 \\
\hline 166 & 89.95 & 8.9 & 4.05 & 45 & 762 & 0.48 & 1.5 & 0.75 & 0.39 \\
\hline 167 & 92.27 & 8.7 & 4.04 & 44 & 891 & 0.49 & 1.5 & 0.76 & 0.49 \\
\hline 170 & 74.89 & 10.3 & 3.9 & 52 & 1132 & 0.47 & 1.6 & 0.76 & 0.48 \\
\hline 46 & 73.88 & 8.5 & 3.2 & 43 & 1461 & 0.62 & 1.3 & 0.67 & 0.73 \\
\hline $\begin{array}{c}\text { Coconu } \\
\mathbf{t} \\
\text { shell } \\
\text { carbon }\end{array}$ & 90.22 & 8.3 & 3.8 & 42 & 168 & 0.5 & 1.6 & - & - \\
\hline
\end{tabular}

the case of the CFCMS. The $\mathrm{CO}_{2}$ adsorption capacity of CFCMS is clearly related to the BET surface area and micropore volume, as shown in Figs. 5 and 6 , respectively. The weight percent of $\mathrm{CO}_{2}$ adsorbed increases with increasing pore volume and BET surface area, apparently reaching peak adsorption capacity at micropore volumes of $\sim 0.5 \mathrm{~cm}^{3} / \mathrm{g}$ and BET surface areas of $\sim 1000 \mathrm{~m}^{2} / \mathrm{g}$ (e.g., sample 170). Figure 7 shows $\mathrm{CO}_{2}$ uptake plotted as a function of micropore size (DR method). The optimum pore size appears to be $\sim 0.8 \mathrm{~nm}$. Significantly, samples 161 and 160 showed the lowest $\mathrm{CO}_{2}$ uptakes (6.9 and $7.8 \%$ respectively), yet they possessed the largest and smallest mean micropore sizes $\left(1.21\right.$ and $0.58 \mathrm{~nm}$ ) respectively, suggesting a strong sensitivity of $\mathrm{CO}_{2}$ uptake to the micropore size. 
ORNL-DWG 94-9363

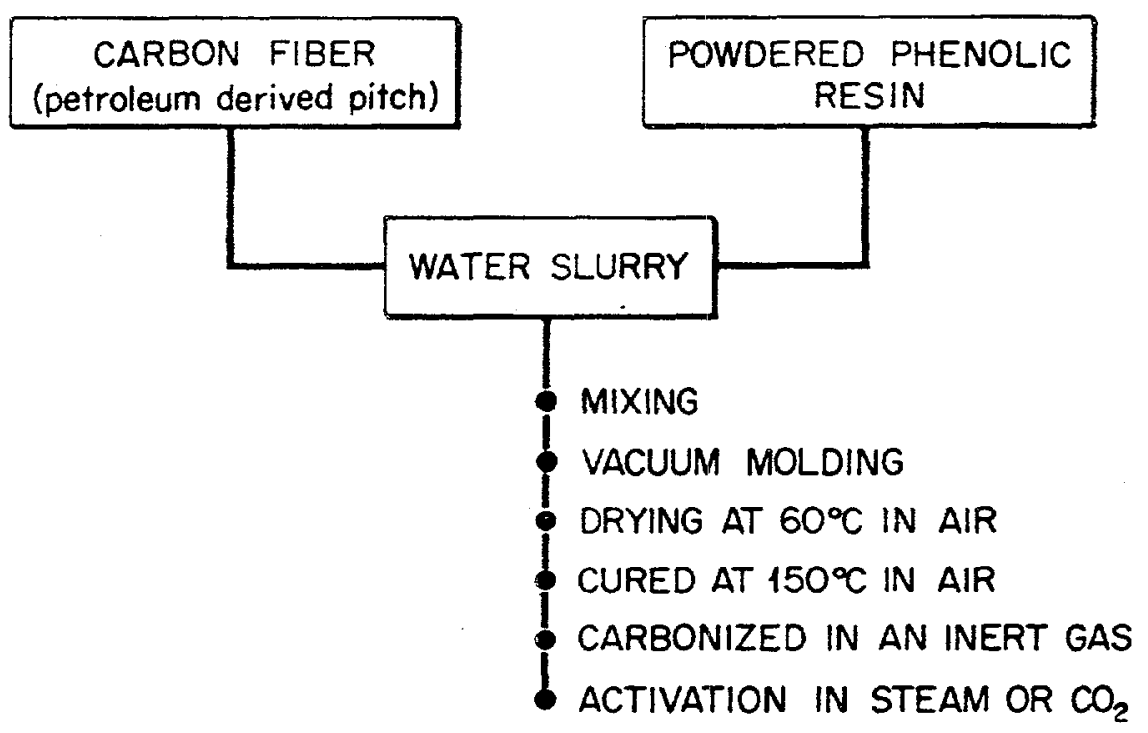

Fig. 1. CFCMS synthesis route.

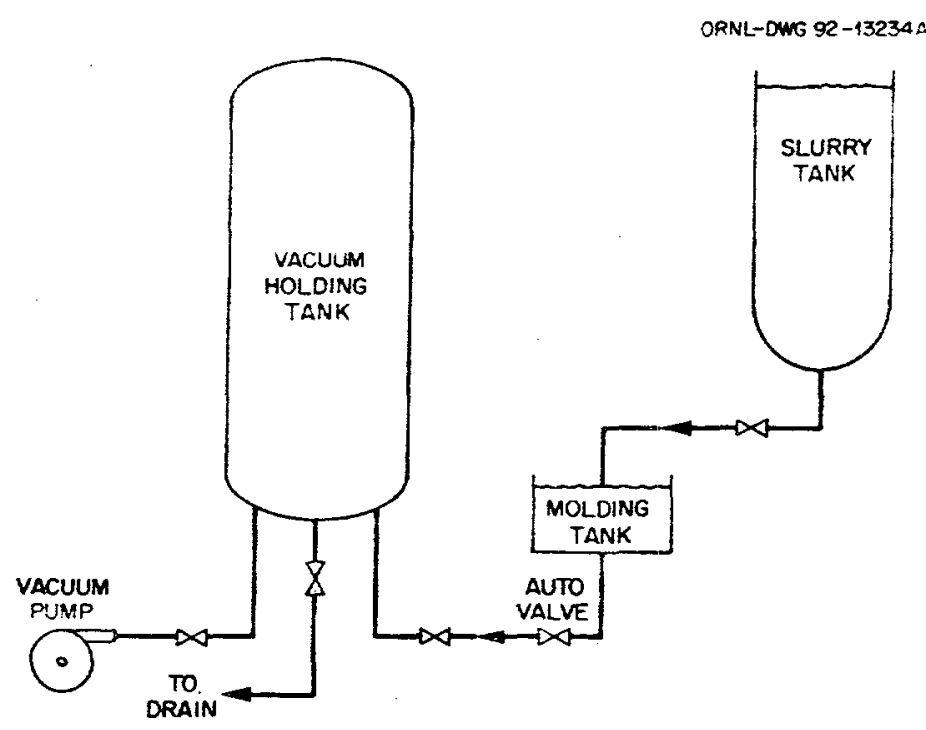

Fig. 2. Schematic illustration of the CFCMS molding apparatus. 


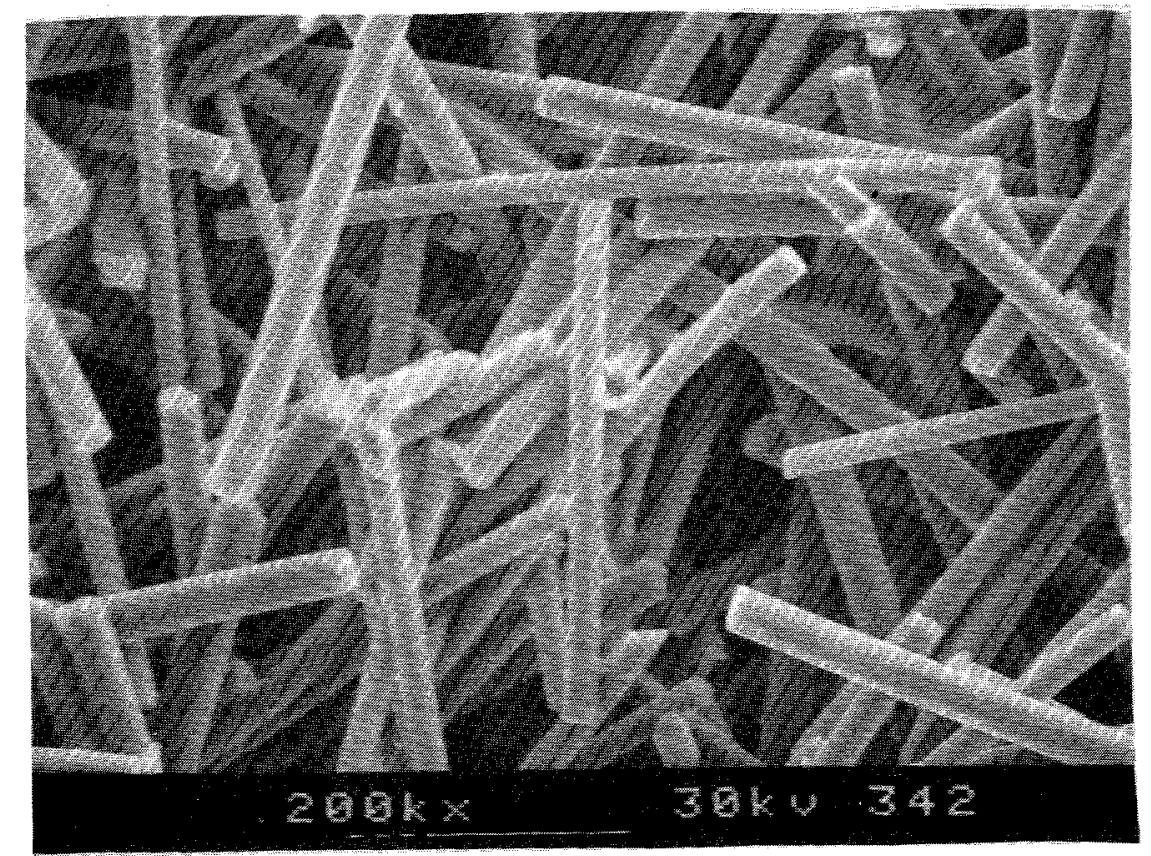

Fig. 3. SEM micrograph of carbon fiber composite molecular sieve (magnification $\times 200$ ).

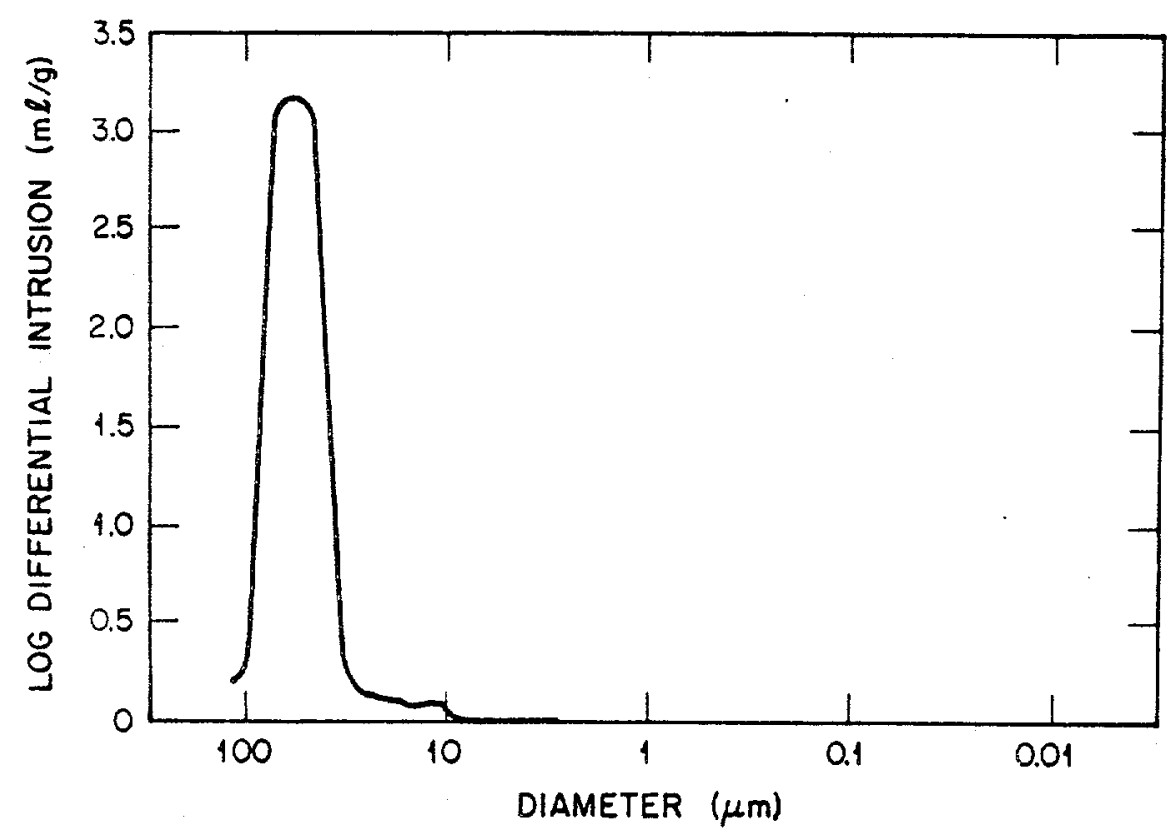

Fig. 4. CFCMS macropore size distribution for a pitch derived carbon fiber monolith obtained from mercury intrusion data. 


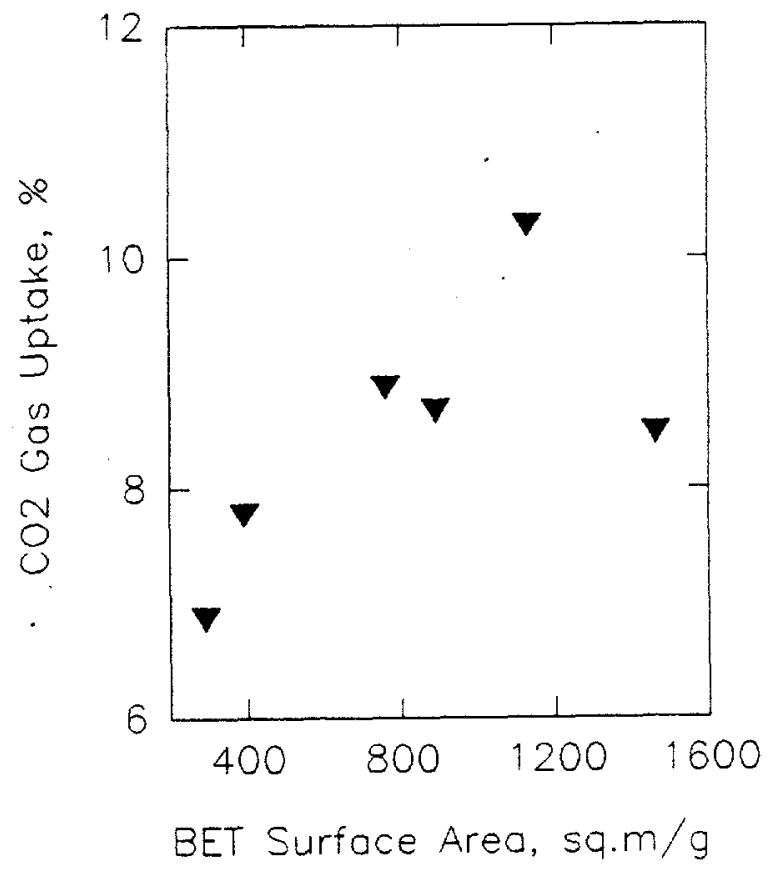

Fig. 5. The relationship between $\mathrm{CO}_{2}$ uptake and BET surface area for CFCMS.

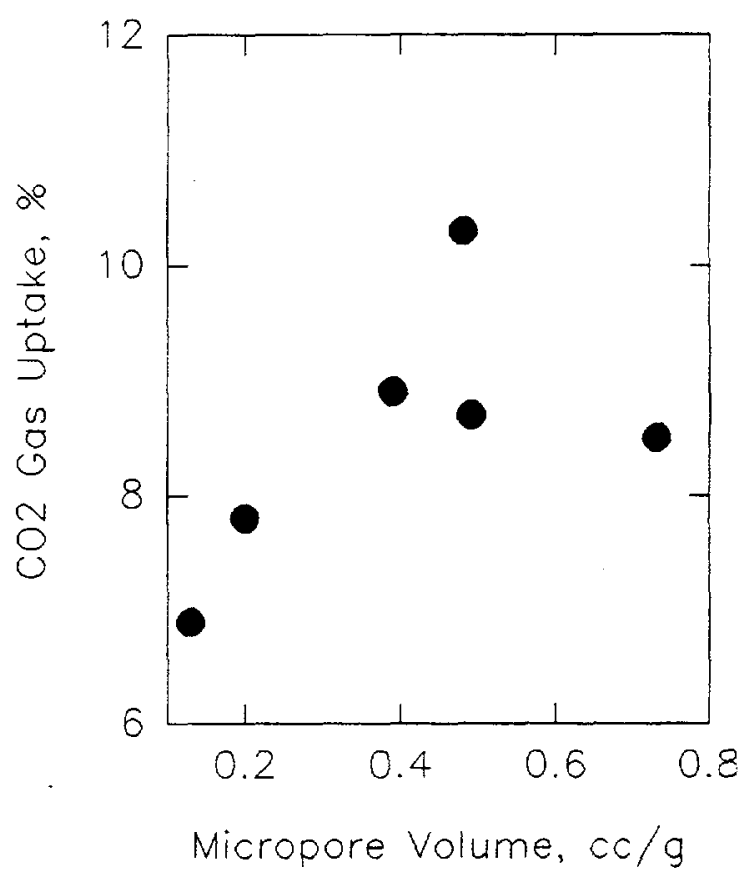

Fig. 6. The relationship between $\mathrm{CO}_{2}$ uptake and micropore volume for CFCMS.

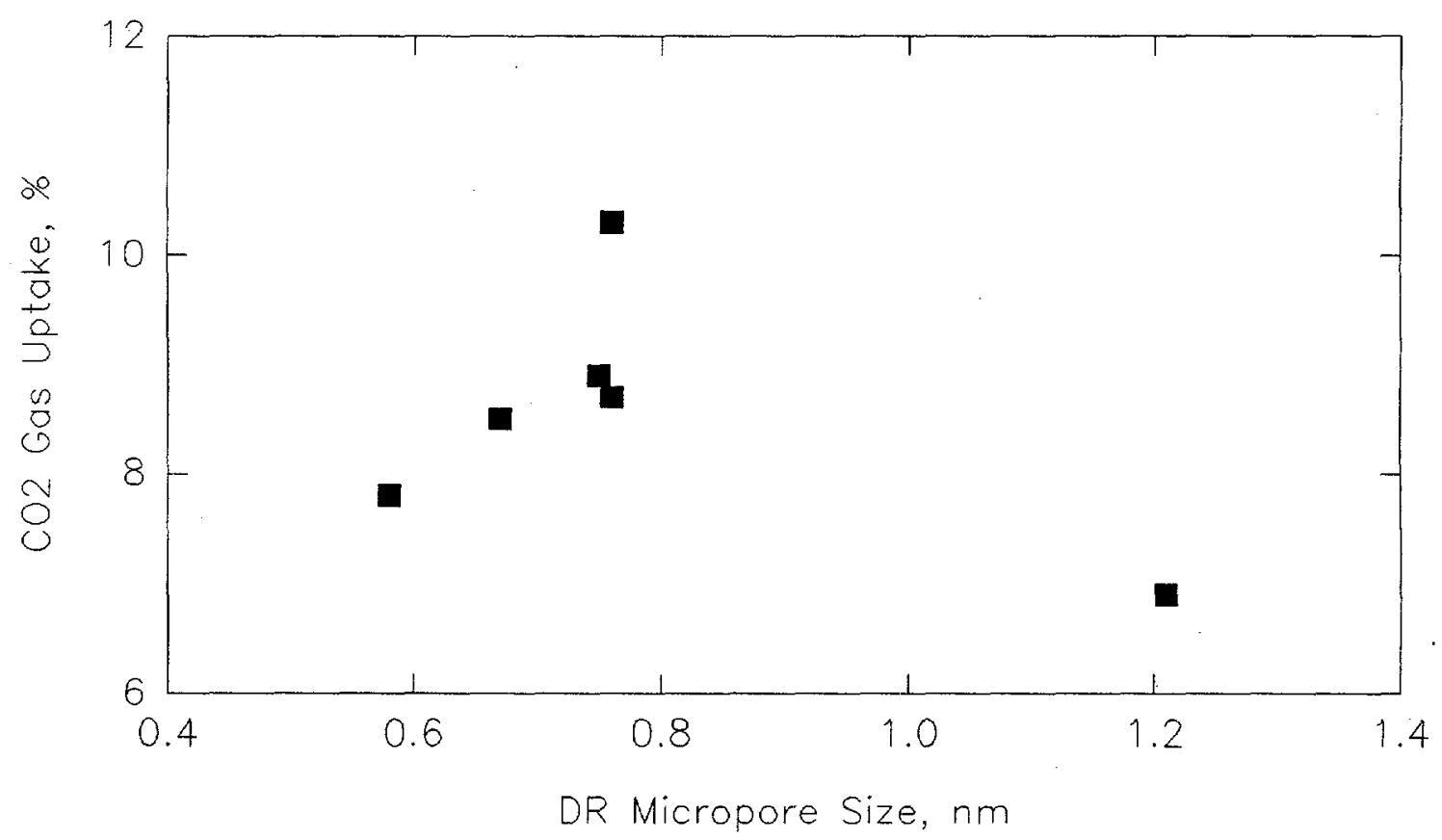

Fig. 7. The relationship between $\mathrm{CO}_{2}$ uptake and mean micropore size for CFCMS. 
Mesoporous Carbon Fiber Monoliths

A series of carbon fiber monoliths ${ }^{5}$ were prepared from PAN derived carbon fibers and activated to burn-offs (\% weight loss on activation) up to $\sim 22 \%$. Subsequent characterization using mercury porosimetry revealed the material to be highly mesoporous. Figure 8 shows the cumulative mesopore surface area as a function of pore diameter. The surface area is clearly associated with pores of size $<50 \mathrm{~nm}$, i.e., the mesopores. The carbonized monoliths exhibited surface areas $>500 \mathrm{~m}^{2} / \mathrm{g}$ and mesopore volumes $>1 \mathrm{~cm}^{3} / \mathrm{g}$. In contrast, the as-received PAN fibers exhibited a mesopore volume of only $0.28 \mathrm{~cm}^{3} / \mathrm{g}$. Evidently, the carbonization process radically affects the PAN fiber pore structure, possibly by opening the surface pores sufficiently to make the internal pores accessible. Access to the fiber's internal pore structure could occur when reactive species such as $\mathrm{O}_{2}$, $\mathrm{CO}_{2}, \mathrm{H}_{2} \mathrm{O}$ and $\mathrm{CO}$ (which were adsorbed during monolith manufacture) are subsequently desorbed during carbonization and gasify the carbon.

The effect of steam activation on the mesopore volume is shown in Fig. 9. The mesopore volume was found to rapidly decrease with increasing burn-off, from $>1 \mathrm{~cm}^{3} / \mathrm{g}$ at zero burn-off to $<0.4 \mathrm{~cm}^{3} / \mathrm{g}$ at $\sim 10 \%$ burn-off. Similarly, the mesopore surface area was found to decrease with

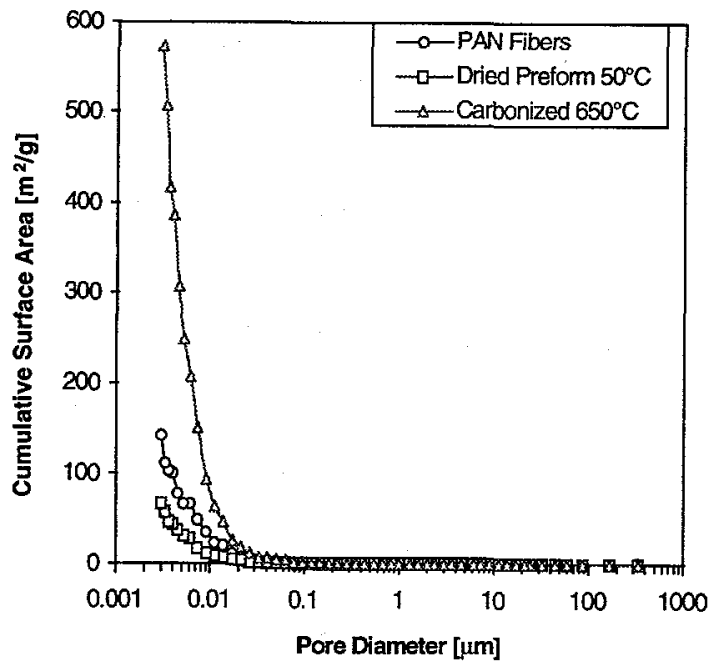

Fig. 8. Mesopore surface area as a function of pore diameter obtained from mercury intrusion data for our PAN derived carbon fiber porous carbon monoliths.

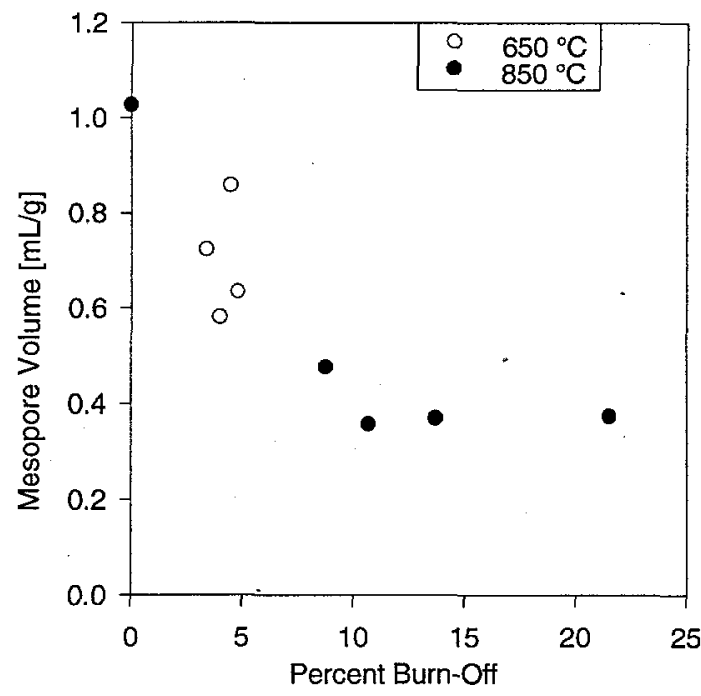

Fig. 9. Mesopore volume as a function of burn-off for our PAN derived carbon fiber porous monoliths. 
increasing burn-off, falling from $>500 \mathrm{~m}^{2} / \mathrm{g}$ at zero burn-off to $<200 \mathrm{~m}^{2} / \mathrm{g}$ at $\sim 10 \%$ burn-off (Fig. 10). The mean mesopore diameter is shown as a function of burn-off in Fig. 11. In the carbonized condition, the carbon fiber monoliths exhibited a mean mesopore width of $\sim 7.2 \mathrm{~nm}$. Activation caused the mean mesopore size to increase, reaching $\sim 8.7 \mathrm{~nm}$ at the peak burn-off considered here.

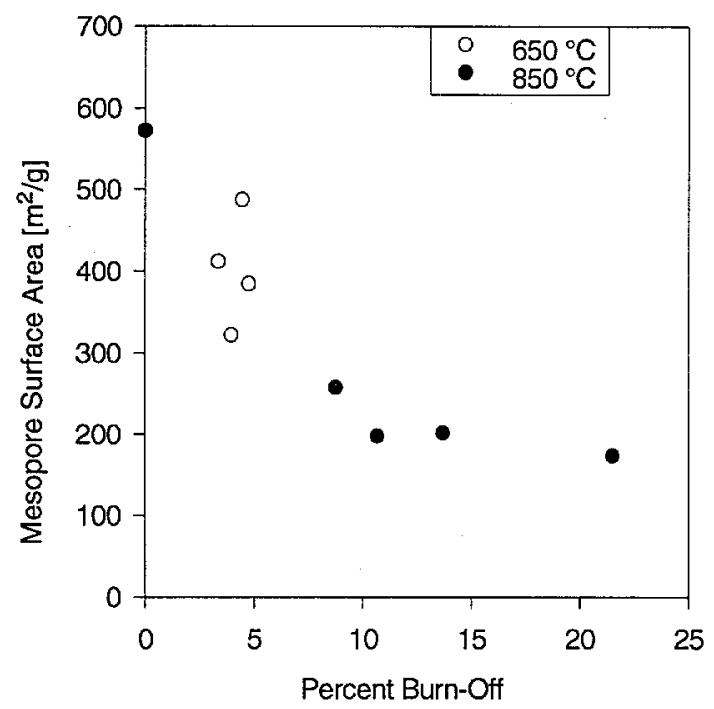

Fig. 10. Mesopore surface area as a function of burn-off for our PAN fiber derived porous carbon monoliths.

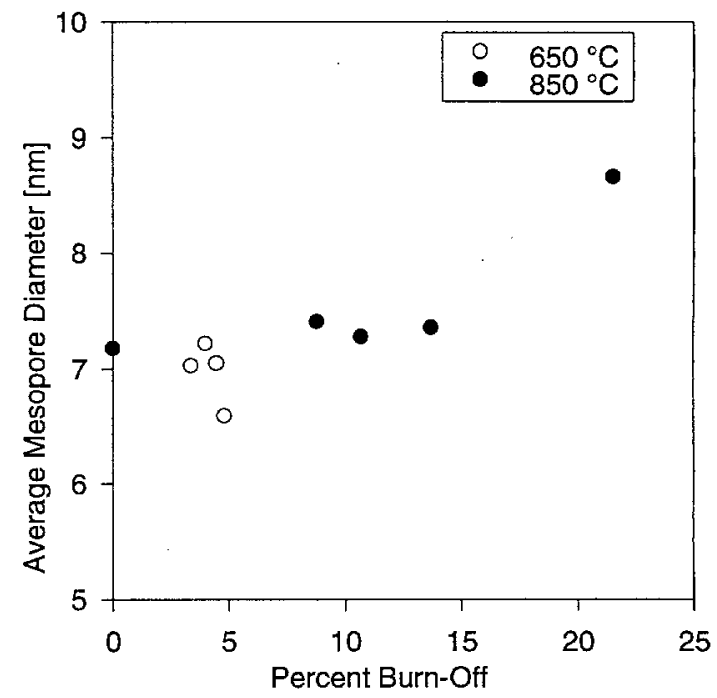

Fig. 11. Mean mesopore diameter as a function of burn-off for our PAN fiber porous carbon monoliths.

The large volume of mesopores observed in the PAN derived fiber monoliths is attributed to the fibril structure of PAN carbon fibers ${ }^{6}$. Typically ${ }^{7}$, the crystallite size in a PAN fiber is $\sim 1.6 \mathrm{~nm}$. Moreover, there is extensive folding of the fibril nature of these crystallites, creating extensive pore networks in the mesopore size range, as confirmed by the data in Fig. 8. The modest increase of mesopore size with increasing burn-off (Fig. 11) suggests that the steam activation process effected very little change to the internal pore structure of the fiber. However, steam activation substantially reduced both the specific mesopore volume and associated specific mesopore surface area (Figs. 9 and 10). Moreover, SEM examination showed that the carbon fiber diameter reduced substantially during activation, indicating the fibers are consumed radially by a process of gasification of their external surface. The observed variations of pore size, pore volume, and surface area with burn-off could be readily explained if activation of the PAN carbon fibers occurred via a constant penetration depth, moving-front reaction. In such a process the pore structure would first be developed by gasification 
of the pore walls, increasing the pore size and volume. With further burn-off, the fiber itself is consumed, thus destroying the pore structure. As the reaction front moves from the periphery of the fiber toward its core, reducing the fiber diameter, the total volume of pores being created or developed is reduced. The high mesopore volume in the carbonized monolith suggests that, in this instance, activation is not required. Significant reductions in process time, and a beneficial cost saving, may thus be realized.

\section{CONCLUSIONS}

A novel porous monolithic carbon fiber composite material, known as CFCMS, has been developed and shows considerable potential for use in PSA gas separation systems. The material can be fabricated in large sizes yet retains the advantageous gas adsorption and separation properties of its precursor isotropic pitch derived carbon fibers. The CFCMS material structure contains large voids $(>30 \mu \mathrm{m})$ between the $10-20 \mu \mathrm{m}$ diameter fibers which allows for free flow of fluids through the material. A series of microporous CFCMS materials have been prepared and characterized. Their $\mathrm{CO}_{2}$ adsorption characteristics were examined and determined to be superior to a commercially available activated carbon. The $\mathrm{CO}_{2}$ adsorption capacity of CFCMS materials is related to both the BET surface area and the micropore volume, and appears to be particularly sensitive to the mean micropore size.

Mesoporous CFCMS materials were prepared from PAN derived carbon fibers. The materials exhibited mesopore volumes in excess of $1 \mathrm{~cm}^{3} / \mathrm{g}$ and, therefore, are candidates for catalyst support applications. Steam activation of the monoliths increased the mean mesopore size only modestly, but reduced the mesopore volume and mesopore surface area significantly. The largest mesopore volumes were associated with the samples that had not been activated, but rather had only been carbonized. An activation and pore structure development mechanism was postulated to explain the pore characterization data obtained from mercury intrusion analysis.

\section{ACKNOWLEDGEMENTS}

Research sponsored by the U.S. Department of Energy, Office of Fossil Energy, Advanced Research and Technology Development Materials Program [DOE/FE AA 151010 0, Work Breakdown 
Structure Element ORNL-1(E)] under contract DE-AC05-84OR21400 with Martin Marietta Energy Systems, Inc.

\section{REFERENCES}

1. T. D. Burchell, "Carbon Fiber Composite Molecular Sieves," in Proc. Eighth Annual Fossil Energy Materials Conference, Oak Ridge, Tennessee, May 10-12, 1994. CONF-9405143, ORNL/FMP94/1, pp. 63-70, Pub. Oak Ridge National Lab., Aug. 1994.

2. Frank Derbyshire, "Activation and Micropore Structure Determination of Carbon Fiber Composite Molecular Sieves," in Proc. Eighth Annual Fossil Energy Materials Conference, Oak Ridge, Tennessee, May 10-12, 1994. CONF-9405143, ORNL/FMP-94/1, pp. 137-143, Pub. Oak Ridge National Lab., Aug. 1994.

3. S. Brunauer, P. H. Emmett, and E. Teller, J. Am. Chem. Soc., Vol 60, p. 309 (1938).

4. George C. Wei and JM Robbins, "Carbon-Bonded Carbon Fiber Insulation for Radioisotope Space Power Systems," Ceramic Bulletin, Vol. 64, No. 5, p. 691 (1985).

5. J. W. Klett and T. D. Burchell, "Carbon Fiber Carbon Composites for Catalyst Supports," Proc. 22nd Conf. on Carbon, San Diego, California, July 1995, Pub. American Carbon Society.

6. R. J. Diefendorf and E. W. Tokarsky, Polymer Eng. Sci., Vol. 15, P. 150 (1975).

7. J. P. Donnet and R. C. Bansal, Carbon Fibers, Pub. Marcel Dekker, Inc., New York (1990). 


\title{
2.6 INVESTIGATION OF AUSTENITIC ALLOYS FOR ADVANCED HEAT RECOVERY AND HOT-GAS CLEANUP SYSTEMS
}

\author{
R. W. Swindeman and W. Ren
}

\section{INTRODUCTION}

The objective of the research on austenitic alloys is to provide databases and design criteria that will assist contractors in selecting optimum alloys for construction of components needed to contain process streams in advanced heat recovery and hot gas cleanup systems. Typical components include: steam line piping and superheater tubing for low emission boilers $\left(600\right.$ to $700^{\circ} \mathrm{C}$ ), heat exchanger tubing for topping cycle systems $\left(650\right.$ to $\left.800^{\circ} \mathrm{C}\right)$, foil materials for recuperators on advanced turbine systems $\left(700\right.$ to $\left.750^{\circ} \mathrm{C}\right)$, heat exchanger tubing for pulsed combustors $\left(650\right.$ to $\left.950^{\circ} \mathrm{C}\right)$, and tubesheets, plenums, and liners for hot gas cleanup systems (850 to $1000^{\circ} \mathrm{C}$ ). The near term objective is to gather data that will permit the consideration of a modified 310 stainless steel and a modified $20 \mathrm{Cr}-25 \mathrm{Ni}-\mathrm{Nb}$ stainless steel for applications to $925^{\circ} \mathrm{C}$ in oxidizing environments or to $870^{\circ} \mathrm{C}$ slightly sulfidizing environments. Planned future work includes the collection of data that will permit the consideration of aluminide clad stainless steels for applications to $1000^{\circ} \mathrm{C}$ in sulfidizing environments.

\section{BACKGROUND}

In the United States, new power generation needs are being met by the use of cogeneration and the installation of medium-size gas turbines. Research in the fossil power industry is largely focused on condition assessment and the repair of aging components. Research related to inspection, damage assessment, and repair is actively supported by fossil power and petrochemical industries. In both industries, replacement of components with "new" and "advanced" materials is sometimes required, and research on the performance of the advanced materials for such components is in progress. Development of advanced materials for the fossil power industry is largely performed in Japan under sponsorship of the Electric Power Research Institute (1). Alloys such as tungsten-vanadium-modified $21 / 4 \mathrm{Cr}, 9 \mathrm{Cr}$, and $12 \mathrm{Cr}$ steels have reached ASME Code status. These steels are candidates for the construction of piping, headers, and tubing in the low emission boiler (LEB) project (2). More research is needed before the complex metallurgical constitution of these alloys is fully understood. Austenitic stainless steels 
for service to higher temperatures in the fossil power industry include niobium-modified 310 stainless steel (3) and titanium-zirconium-modified $20 \mathrm{Cr}-25 \mathrm{Ni}-\mathrm{Nb}$ stainless steel (4). Both of these alloys are intended for superheater tubing, and service temperatures are limited to approximately $730^{\circ} \mathrm{C}$. Both steels are candidates for heat exchanger tubing in the LEB and the advanced topping cycle. For higher temperature service in the petrochemical industry, a commercial modified alloy 800 has been developed (5), and, for sulfidation resistance, a commercial cobalt-bearing alloy has been produced (6). Both alloys are "new" and much has to be learned about their high temperature performance. Three commercial stainless steels that have been used in the construction of components in advanced fossil energy systyems include type $310 \mathrm{~S}$ stainless steel, a silicon-aluminum modified steel, and a rare earth modified steel. Compositions are listed in Table 1. A careful reiew of the performance and costs of the materials indicated that there was a need for an additional material. A modified 310 stainless steel having strength equivalent to alloy $800 \mathrm{H}$ would have applications above $800^{\circ} \mathrm{C}(7)$.

Table 1. Typical Compositions of High Temperature Austenitic Alloys (wt\%)

\begin{tabular}{|c|c|c|c|c|c|c|}
\hline ELEMENT & $\begin{array}{c}310 \mathrm{HCb} \\
\mathrm{N}\end{array}$ & NF-709 & HR-120 & HR-160 & RA85H & 253MA \\
\hline $\mathrm{Fe}$ & Balance & Balance & 36 & 4 & Balance & Balance \\
\hline $\mathrm{Ni}$ & 20 & 25 & 37 & Balance & 14.5 & 11 \\
\hline $\mathrm{Cr}$ & 25 & 20 & 25 & 28 & 18.5 & 21 \\
\hline $\mathrm{Co}$ & & & & 30 & & \\
\hline $\mathrm{C}$ & 0.05 & 0.07 & 0.05 & 0.05 & 0.2 & 0.08 \\
\hline $\mathrm{Si}$ & 0.5 & 0.5 & 0.6 & 2.8 & 3.5 & 1.7 \\
\hline $\mathrm{Mn}$ & 1.6 & 1 & 0.7 & 0.5 & 0.8 & 0.6 \\
\hline $\mathrm{Nb}$ & 0.4 & 0.25 & 0.7 & & & \\
\hline $\mathrm{Mo}$ & & 1.5 & & & & \\
\hline $\mathrm{N}$ & 0.25 & 0.18 & 0.2 & & & 0.17 \\
\hline $\mathrm{Al}$ & & & 0.1 & & 1.0 & \\
\hline $\mathrm{Ti}$ & & 0.06 & 0.1 & & & \\
\hline $\mathrm{B}$ & & 0.004 & 0.004 & & & \\
\hline $\mathrm{Rare} \mathrm{earth}$ & & & & & & 0.04 \\
\hline
\end{tabular}

Notes: NF-709 is a trademark of Nippon Steel Corporation, HR-160 and HR-120 are registered trademarks of Haynes Alloys, International, RA85H is a registered trademark of Rolled Alloys, Inc., and 253MA is a registered trademark of AVESTA AB. 


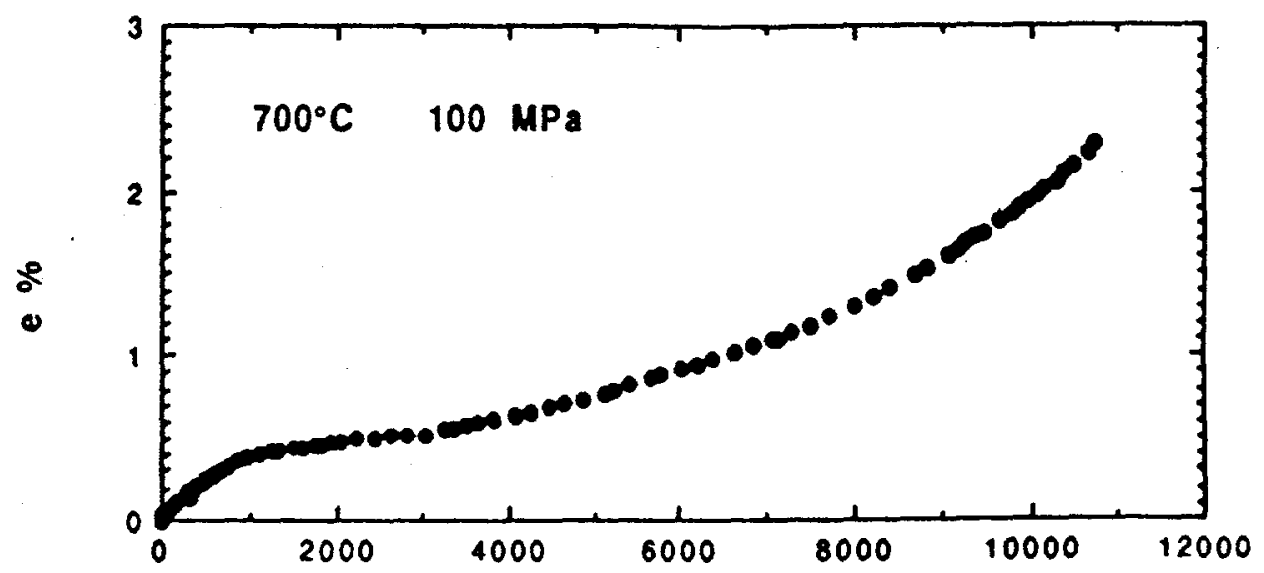

Time (h)

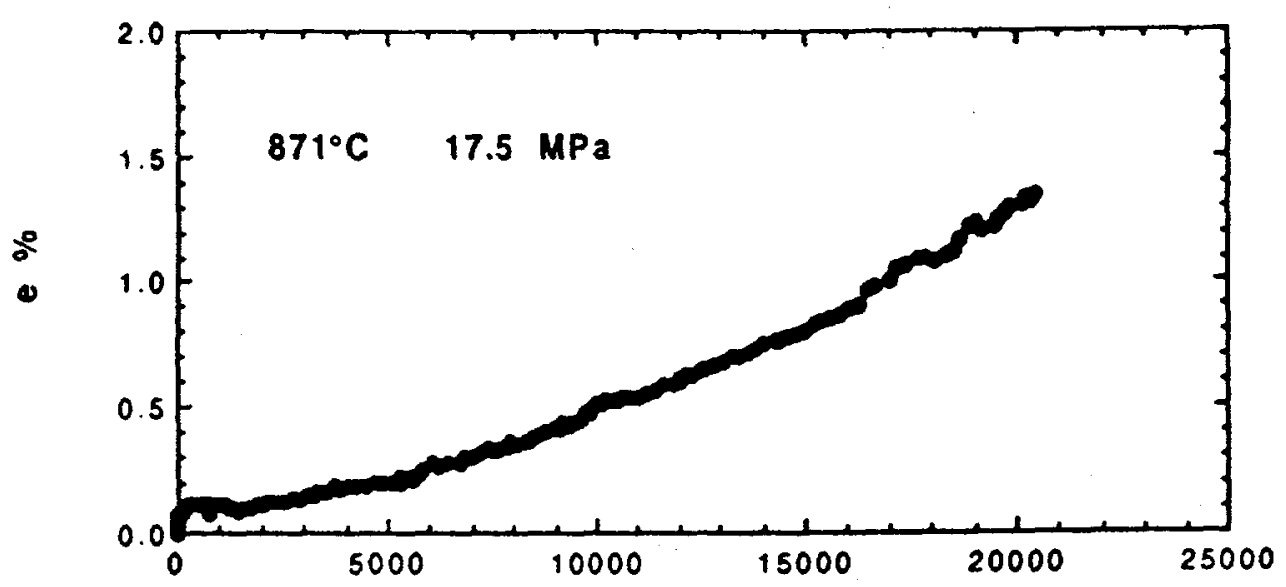

Time (h)

Fig. 1. The 310TaN stainless steel exhibits very little primary creep at all temperatures. 


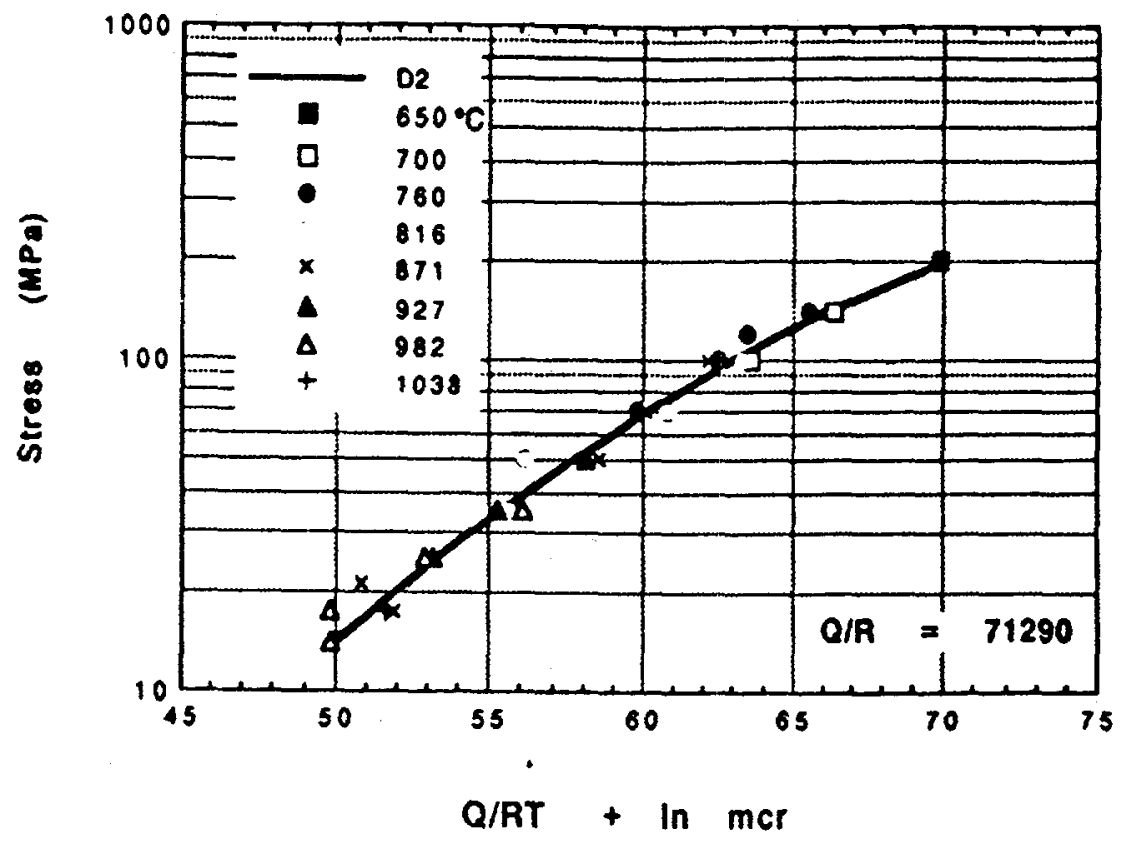

Fig. 2. Parametric analysis of MCR data produced an activation energy near $144 \mathrm{Kcal}$ and a stress exponent near 5 .

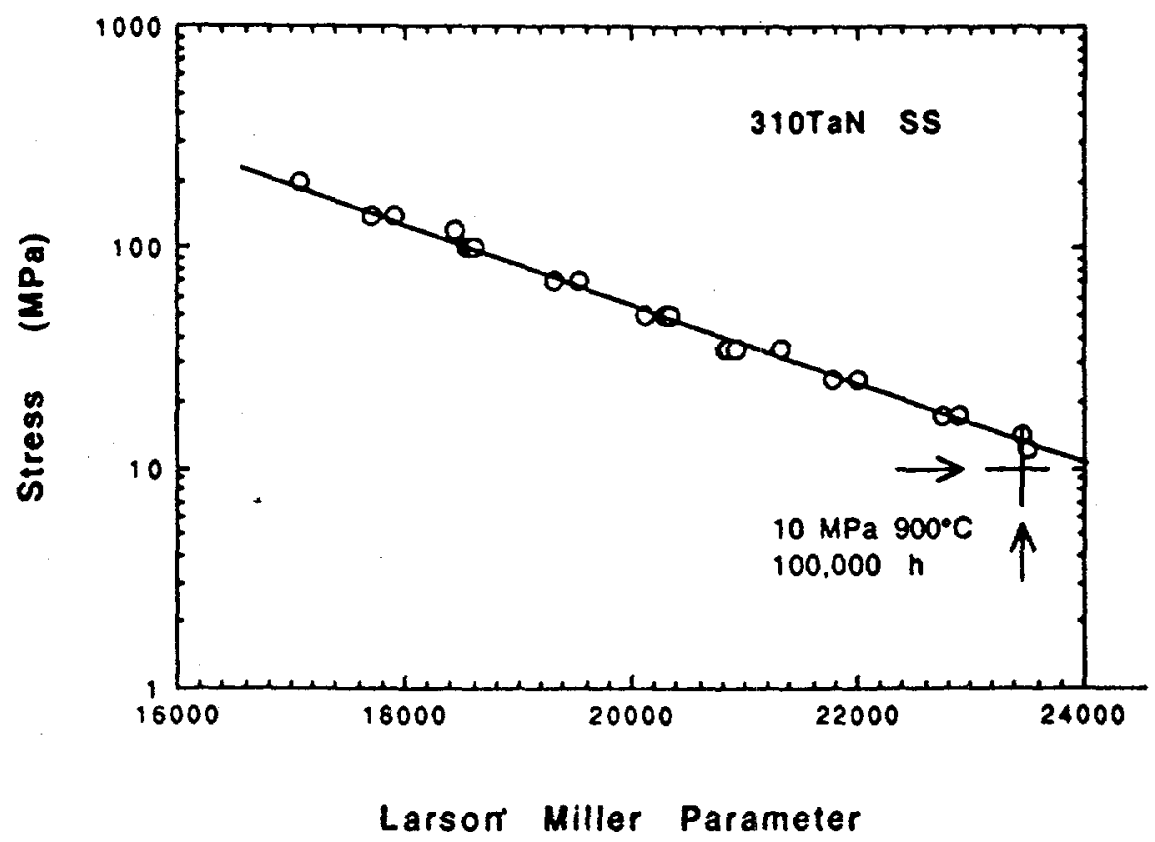

Fig. 3. Parametric analysis of rupture data to $10,000 \mathrm{~h}$ suggests that the target strength can be achieved. 


\section{EXPERIMENTAL WORK ON MODIFIED 310 STAINLESS STEEL}

Commercial alloys were obtained from alloy suppliers, and small heats of experimental alloys were purchased from various sources. Products were fabricated into convenient forms (plates and sheets) for weldability studies, mechanical testing, and corrosion testing. Short-time tensile and stress-rupture testing was used to establish optimum solution treating conditions, and longer creep and stress-rupture testing was performed in the temperature range of interest for the alloys.

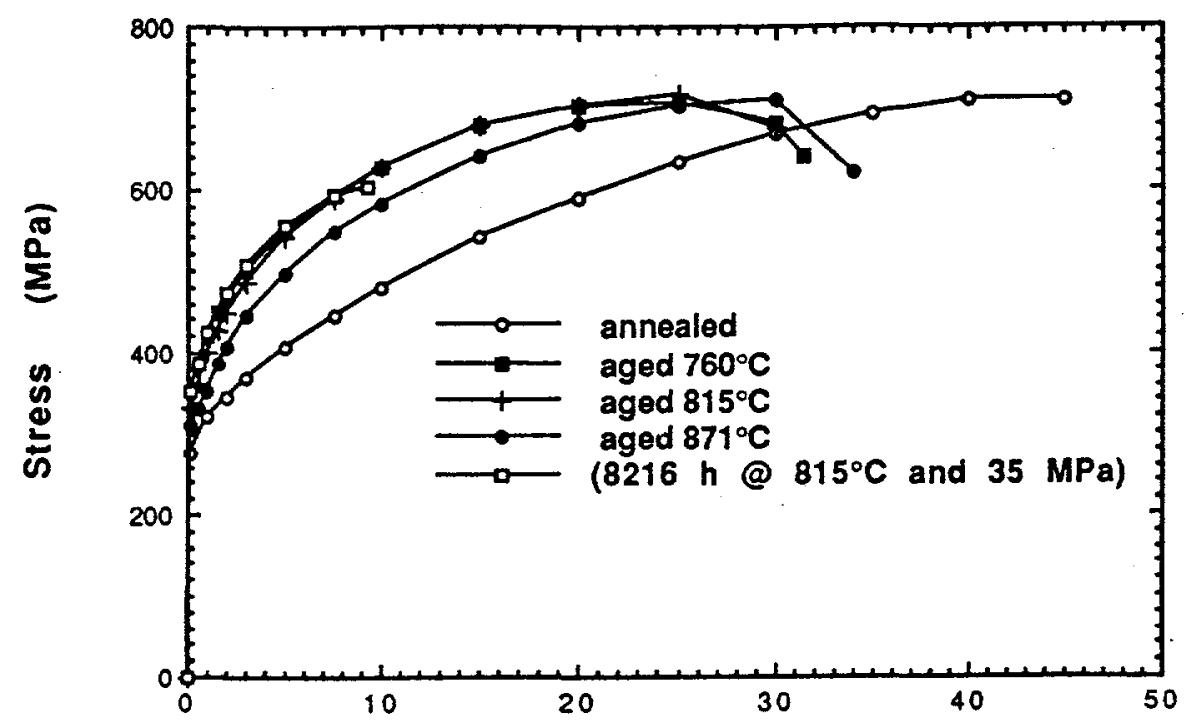

Fig. 4. Aging for 1000 hours produces a reduction of ductility in $310 \mathrm{TaN}$ stainless steel.

For modified 310 stainless steel it was found that an anneal at $1200^{\circ} \mathrm{C}$ produced the best creep-rupture strength for tempeatures above $800^{\circ} \mathrm{C}$. Creep curves to time beyond 10,000 hours indicated relatively stable behavior, as shown the creep curves plotted in Fig. 1. The minimum creep rates determined from tests in the temperature range of 650 to $1038^{\circ} \mathrm{C}$ were correlated on the basis of a constant activation energy near $144 \mathrm{kcal} / \mathrm{mole}$. The trend is shown in Fig. 2 . Larson-miller parametric analysis of the stress-rupture data for the modifed 310 stainless steel indicated that a single parametric constant near 15 correlated rupture data over a broad range of temperatures and times, as shown in Fig. 3. Annalysis further indicated that the target strength of $10 \mathrm{MPa}$ for $100,000 \mathrm{~h}$ at $900^{\circ} \mathrm{C}$ could be achieved. Tensile and bend tests were performed on aged specimens. Room temperature tensile stress versus strain curves for aged specimens were 
compared to unaged material in Fig. 4. It was observed that $1000 \mathrm{~h}$ of aging reduced the ductility of modified 310 stainless steel by 30 per cent.

\section{DESIGN CRITERIA FOR VERY HIGH TEMPERATURES}

Components in several advanced fossil energy systems are expected to experience very high temperatures, and the potential for creep damage, fatigue, thermal-fatigue, and creep-fatigue crack growth are significant. Issues that are of concern include the proper selection of design margins on life. To some extent, design engineers rely on construction codes such as those developed by the American Petroleum Institute or the American Society of Mechanical Engineers. However, several of the candidate materials for components are not code-approved materials, and, even for the code-approved materials, data for design at very high temperaturs are often lacking. For these reasons, exploratory research on creep, creep-fatigue, fatigue, and crack growth of several candidate alloys has been in progress $(8,9)$.

Early work involved studies of alloy 333 and 556, which were candidatres for used in pressurized fluidized bed (PFBC) hot gas cleanup systems. More recently alloy 160 has been investigated. Techniques for creep- and fatigue-crack growth measurements were developed for temperatures to $950^{\circ} \mathrm{C}$, and experiments were performed on alloy 160 . Tensile and creep tests were included on base metal and weld metal.

\section{PUBLICATIONS}

(1) M. Ohgami, et al., "Mechanical Properties of $9 \mathrm{Cr}-0.5 \mathrm{Mo}-1.8 \mathrm{~W}$ Steel Tubes Exposed in a Fossil Power Plant, paper presented at the International Symposium on Improved Technology for Fossil Power Plants-New \& Retrofit Applications, March 1-3, 1993, Washington, D.C.

(2) D. Sopocy, et al., "Using the State of the Art Power Plant (SOAPP) Workstation for Planning and Conceptual Design, paper presented at the International Symposium on Improved Technology for Fossil Power Plants-New \& Retrofit Applications, March 1-3, 1993, Washington, D.C.

(3) K. Yoshikawa, et al., Development of New Boiler Tubes with High Elevated Temperature Strength and Corrosion Resistance," paper 5-167, First International Conference on Improved Coal Fired Power Plants, EPRI publication CS-5581-SR, Electric Power Research Institute, Palo Alto, California, 1988. 
(4) T. Takahashi, el al., Development of a High Strength $25 \mathrm{Ni}-20 \mathrm{Cr}$ Steel for Tubes in Ultra Supercritical Power Boilers," paper 41-1 in Second International Conference on Improved Coal Fired Power Plants, EPRI publication GS-6422, Electric Power Research Institute, Palo Alto, California, 1989.

(5) S. C. Ernst and G. Y. Lai, "A New High Strength Fe-Ni-Cr-Nb-N Alloy for Elevated Temperature Applications," pp. 115-121 in Heat Resistant Materials, ASM International, Materials Park, Ohio, 1991.

(6) C. M. Anthony, S. K. Srivastava, and G. Y. Lai, pp. 667-73 in in Heat Resistant Materials, ASM International, Materials Park, Ohio, 1991.

(7) R. W. Swindeman, The Potential of Modified Type 310 Stainless Steel for Advanced Fossil Energy Applications, ORNL-TM-12057, Oak Ridge National Laboratory, Oak Ridge, TN (March, 1992).

(8) R. W. Swindeman and D. L. Marriott, "Criteria for Design with Structural Materials in Combined-Cycle Applications above $815^{\circ} \mathrm{C}$," J. Engineering for Gas Turbines and Power, 116, 352-59 (April, 1994).

(9) W. Ren, et al., Creep and Creep Crack Propagation Behavior of Haynes HR160 Superalloy, Final Report for SURA/ORAU/ORNL 1994 Summer Cooperative Program, October , 1994. 



\title{
$2.7 \mathrm{Cr}_{2} \mathrm{Nb}$ - BASED ALLOY DEVELOPMENT
}

\author{
C. T. Liu, P. F. Tortorelli, J. A. Horton, D. S. Easton, J. H. Schneibel, \\ L. Heatherly, C. A. Carmichael, M. Howell, and J. L. Wright \\ Oak Ridge National Laboratory \\ Oak Ridge, Tennessee 37831
}

\section{INTRODUCTION}

The objective of this task is to develop a new generation of structural materials based on intermetallic alloys for use as critical hot components in advanced fossil energy conversion systems. The intermetallic phase, $\mathrm{Cr}_{2} \mathrm{Nb}$, with a complex cubic structure $(\mathrm{C}-15)^{1,2}$ has been selected for this development because of its high melting point $\left(1770^{\circ} \mathrm{C}\right),{ }^{2-4}$ relatively low material density $\left(7.7 \mathrm{~g} / \mathrm{cm}^{2}\right),{ }^{5}$ excellent high-temperature strength (at 1000 to $\left.1250^{\circ} \mathrm{C}\right), 6,7$ and potential resistance to oxidation and corrosion. $3,8,9$ This intermetallic phase, like many other Laves phases, has a wide range of compositional homogeneity 2,4 suggesting the possibility of improving its mechanical and metallurgical properties by alloying additions.

The major engineering concern with $\mathrm{Cr}_{2} \mathrm{Nb}$ and other $\mathrm{A}_{2} \mathrm{~B}$ Laves phases is their poor fracture toughness and fracture resistance at ambient temperatures. $3,6,7,10$ The single-phase $\mathrm{Cr}_{2} \mathrm{Nb}$ is very hard $(\sim 800 \mathrm{DPH})$ and brittle at room temperature. ${ }^{11}$ Because of this brittleness, the development effort has concentrated on two-phase structures containing the hard intermetallic phase $\mathrm{Cr}_{2} \mathrm{Nb}$ and the softer $\mathrm{Cr}$-rich solid solution phase. Previous studies indicate that the two-phase $\mathrm{CN}$ alloys exhibited significant plastic deformation prior to fracture under compressive tests at room temperature. ${ }^{6,7,11}$ The alloys showed excellent compressive strength at room and elevated temperatures, with the yield strength much superior to nickel-base superalloys and $\mathrm{Ni}_{3} \mathrm{Al}$ alloys at and above $1000^{\circ} \mathrm{C}$. The $\mathrm{CN}$ alloys, however, showed poor fracture strength in tension at ambient temperatures.

Potential applications of $\mathrm{Cr}-\mathrm{Cr}_{2} \mathrm{Nb}$ alloys include hot components (for example, air heat exchangers and turbine blades) in advanced energy conversion systems and heat engines, wear-resistant parts in coal handling systems (e.g., nozzles), drill bits for oil/gas wells, and valve guides in diesel engines. Current studies are focused on enhancement of fracture resistance in tension at ambient temperatures and oxidation resistance above $1000^{\circ} \mathrm{C}$. This report summarizes recent progress on controlling microstructure and improving the mechanical and metallurgical properties and the high-temperature corrosion behavior of $\mathrm{Cr}$ $\mathrm{Cr}_{2} \mathrm{Nb}$ alloys through alloying additions, material processing, and heat treatment. 


\section{ALLOY PREPARATION AND PROCESSING}

$\mathrm{Cr}(\mathrm{Nb})-\mathrm{Cr}_{2} \mathrm{Nb}$ alloys weighing $400 \mathrm{~g}$ were prepared by arc melting and drop casting in a copper mold $\left(2.5 \mathrm{~cm}\right.$ diam $\times 7.6 \mathrm{~cm}$ long) preheated at 100 to $300^{\circ} \mathrm{C}$. High-purity niobium and chromium metal chips were used as charge materials. The alloy ingots generally contain certain defects, including oxide inclusions and as-cast porosity ranging in size from a few to several hundred microns. The alloys also exhibit a coarse eutectic structure including interconnected $\mathrm{Cr}_{2} \mathrm{Nb}$ plates, which adversely affect their mechanical (tensile) properties.

In order to minimize the casting defects and to refine the cast eutectic structure, selected alloy ingots were clad inside molybdenum billets and hot extruded at 1450 to $1500^{\circ} \mathrm{C}$ at an extrusion ratio of 4 to 1 . Some alloys were successfully hot extruded into $1.3 \mathrm{~cm}$ bar stock, and others were cracked into pieces. The tendency for cracking was not simply correlated with alloy composition. It appeared that the cracking may be related to casting defects.

Preparation of $\mathrm{CN}$ alloys using elemental powders has just been initiated. In this case, the powders were mixed completely to give the correct alloy compositions and then placed inside molybdenum cans. The filled cans were then degassed in a vacuum chamber and sealed by electron-beam welding. They were hot extruded at $1480^{\circ} \mathrm{C}$ to produce $\mathrm{CN}$ alloys. Initial results indicate the as-extruded bars contained many foreign particles which were identified as aluminum and niobium oxides by energy dispersive $\mathrm{x}$-ray spectroscopy (EDS). The amount of the oxide phase depended on the way the powders were prepared prior to insertion into the molybdenum cans. Significant recent progress was made in decreasing the amount of the oxide phases by reducing interstitial contamination during the powder processing.

\section{MICROSTRUCTURAL ANALYSIS}

Alloying additions, heat treatment, and material processing all strongly affect the microstructure of $\mathrm{Cr}(\mathrm{Nb})-\mathrm{Cr}_{2} \mathrm{Nb}$ alloys. Figure 1 compares the as-cast microstructure of two alloys, CN-96 and -97 containing $12 \% \mathrm{Nb}$ and other alloying additions. (All compositions are at.\% unless otherwise noted.) The compositional difference of the two alloys is that $\mathrm{CN}$ 97 had $0.1 \mathrm{wt} \%$ of a minor alloying addition (designated as X5). As shown in Fig. 1, the base alloy CN-96 exhibits a typical lamellar-type eutectic structure (Fig. 1a) while the doped alloy $\mathrm{CN}-97$ shows blocky particles in the eutectic structure. In these photos, the Cr-rich phase 
appears as light gray while the $\mathrm{Cr}_{2} \mathrm{Nb}$ is darker. The primary $\mathrm{Cr}$-rich patches precipitated out fine $\mathrm{Cr}_{2} \mathrm{Nb}$ particles after annealing at 1200 to $1300^{\circ} \mathrm{C}$ (as shown in Fig. 2 for $\mathrm{CN}-103$ ).

Hot extrusion at 1450 to $1500^{\circ} \mathrm{C}$ was apparently effective in breaking the interconnected $\mathrm{Cr}_{2} \mathrm{Nb}$ phase in the eutectic structure. This is shown in Fig. 3 for $\mathrm{CN}-90$ containing $6 \% \mathrm{Nb}$ and other alloying additions. The coarse $\mathrm{Cr}_{2} \mathrm{Nb}$ plates that formed around primary $\mathrm{Cr}$-rich patches (Fig. 3a) were broken into blocky particles (Fig. 3b) after hot extrusion at $1480^{\circ} \mathrm{C}$.

The alloys $\mathrm{CN}-80,-85$, and -87 were examined by transmission electron microscopy (TEM). All the alloys were hot extruded at $1480^{\circ} \mathrm{C}$ and annealed for $3 \mathrm{~d}$ at $1200^{\circ} \mathrm{C}$. Alloy disks were prepared by ion milling at $6 \mathrm{kV}$ and were examined in a Philips CM30 at $300 \mathrm{kV}$. Figure 4 is a TEM micrograph showing $\mathrm{Cr}_{2} \mathrm{Nb}$ particles observed in $\mathrm{CN}-85$ which was annealed for $3 \mathrm{~d}$ at $1200^{\circ} \mathrm{C}$. The blocky particles contain numerous microtwins. This may be due to the $\mathrm{C} 14 \rightarrow \mathrm{C} 15$ transformation. The study of the crystal structure of these particles is in progress. Dislocations and dislocation networks are generally observed in the $\mathrm{Cr}$-rich phase, but they are very seldom observed in $\mathrm{Cr}_{2} \mathrm{Nb}$ particles.

An EDAX 9100 spectrometer was used to perform EDS in conjunction with the TEM studies. The EDS analyses were made on precipitates that intersected the ion milling perforations, thereby minimizing the contributions from surrounding matrix material. The results were averaged and are shown in Table 1 . Here $\mathrm{X} 1, \mathrm{X} 2, \mathrm{X} 3$, and $\mathrm{X} 4$ represent the beneficial elements added to the $\mathrm{Cr}-\mathrm{Nb}$ alloys. $\mathrm{X} 1$ was added for refining the coarse eutectic structure, X2 was for improving oxidation resistance, X3 for enhancing the hightemperature strength, and $\mathrm{X} 4$ for ease of fabrication. The $\mathrm{Cr}$-rich solid solution (that is, the

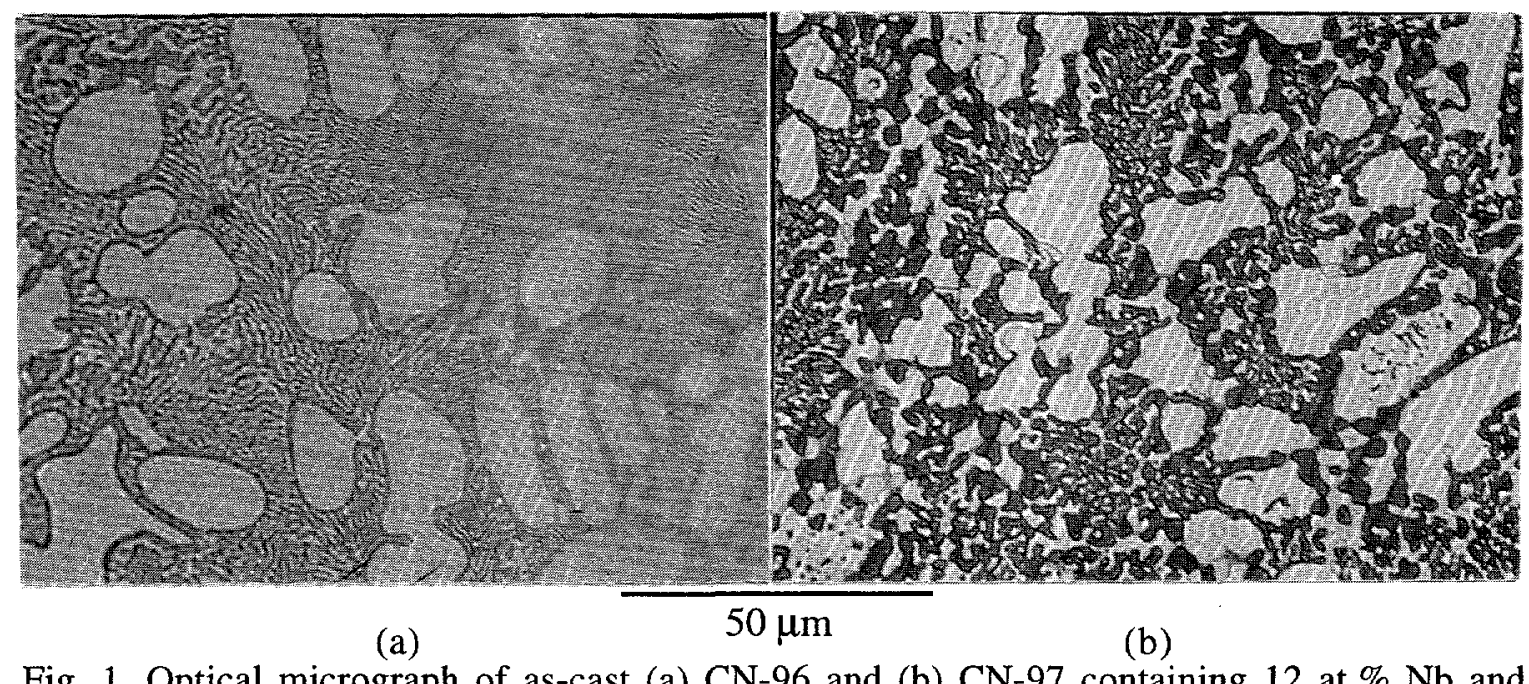

Fig. 1. Optical micrograph of as-cast (a) $\mathrm{CN}-96$ and (b) $\mathrm{CN}-97$ containing 12 at.\% $\mathrm{Nb}$ and other alloying additions. The difference in composition is that $\mathrm{CN}-97$ has $0.1 \mathrm{wt} \% \mathrm{X} 5$. 


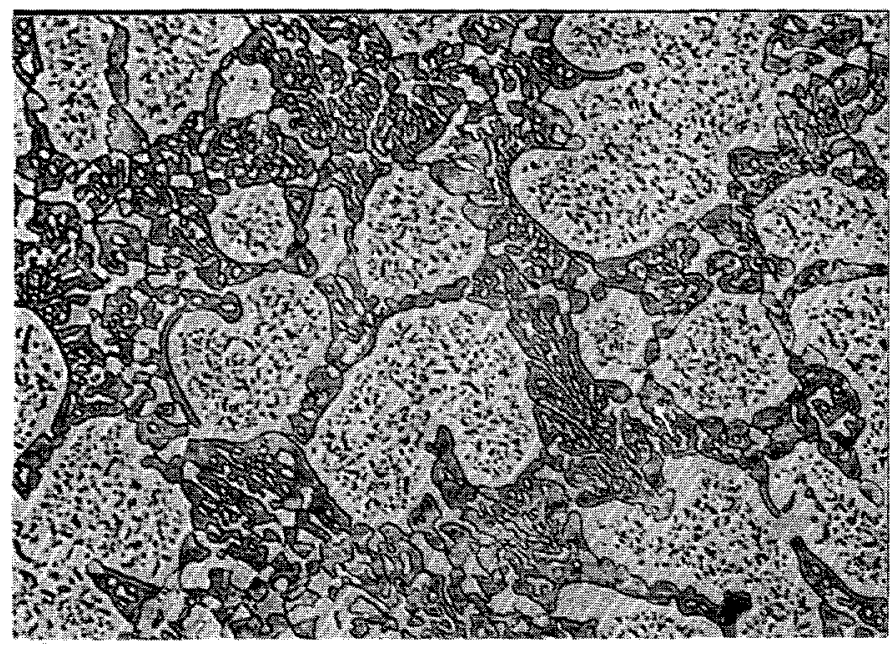

Fig. 2. Optical micrograph of CN103 containing 10 at. $\% \mathrm{Nb}$ and 0.1 wt $\%$ X5. The alloy was annealed for $1 \mathrm{~d}$ at $1300^{\circ} \mathrm{C}$ and $2 \mathrm{~d}$ at $1200^{\circ} \mathrm{C}$.

$50 \mu \mathrm{m}$

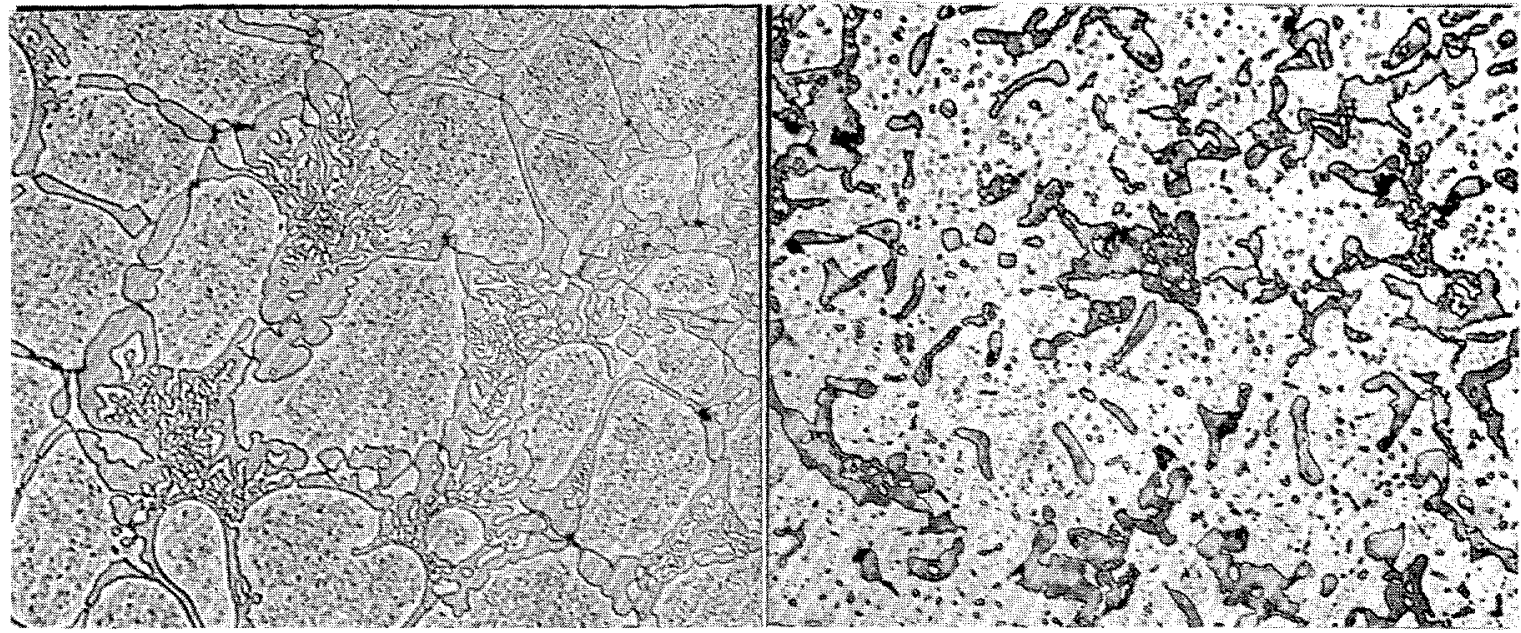

(a)

$50 \mu \mathrm{m}$

(b)

Fig. 3. Comparison of optical micrograph of $\mathrm{CN}-90$ in (a) as-cast plus $1 \mathrm{~d}$ at $1200^{\circ} \mathrm{C}$ anneal and (b) hot extrusion at $1480^{\circ} \mathrm{C}$ plus $1 \mathrm{~d}$ at $1200^{\circ} \mathrm{C}$ anneal.

matrix phase) in $\mathrm{CN}-80,-85$, and -87 dissolves a small amount $(\leq 1 \%)$ of niobium. The $\mathrm{Cr}_{2} \mathrm{Nb}$-type phase, on the other hand, contains more than $27 \% \mathrm{Nb}$, and the exact amount of niobium in this phase depends on the partitioning of alloying additions in the $\mathrm{CN}$ alloys. The element $\mathrm{X} 1$ partitions more or less equally in the $\mathrm{Cr}_{2} \mathrm{Nb}$ and the Cr-rich phases in $\mathrm{CN}-80$ and -85 , and preferentially in the $\mathrm{Cr}_{2} \mathrm{Nb}$ phase in $\mathrm{CN}-87$ (containing $20 \% \mathrm{X} 4$ ). A careful examination of the $\mathrm{Cr}_{2} \mathrm{Nb}$ compositions suggest $\mathrm{X} 1$ essentially occupies the chromium subsites. The element $\mathrm{X} 2$ in $\mathrm{CN}-85$ and -87 partitions strongly in the $\mathrm{Cr}_{2} \mathrm{Nb}$-type phase, as shown in Table 1. The element X4 was distributed roughly equal in the two phases in $\mathrm{CN}-87$. The partitioning behavior of these alloying elements could not be rationalized by considering both reactivity and atomic size of the alloying elements. 


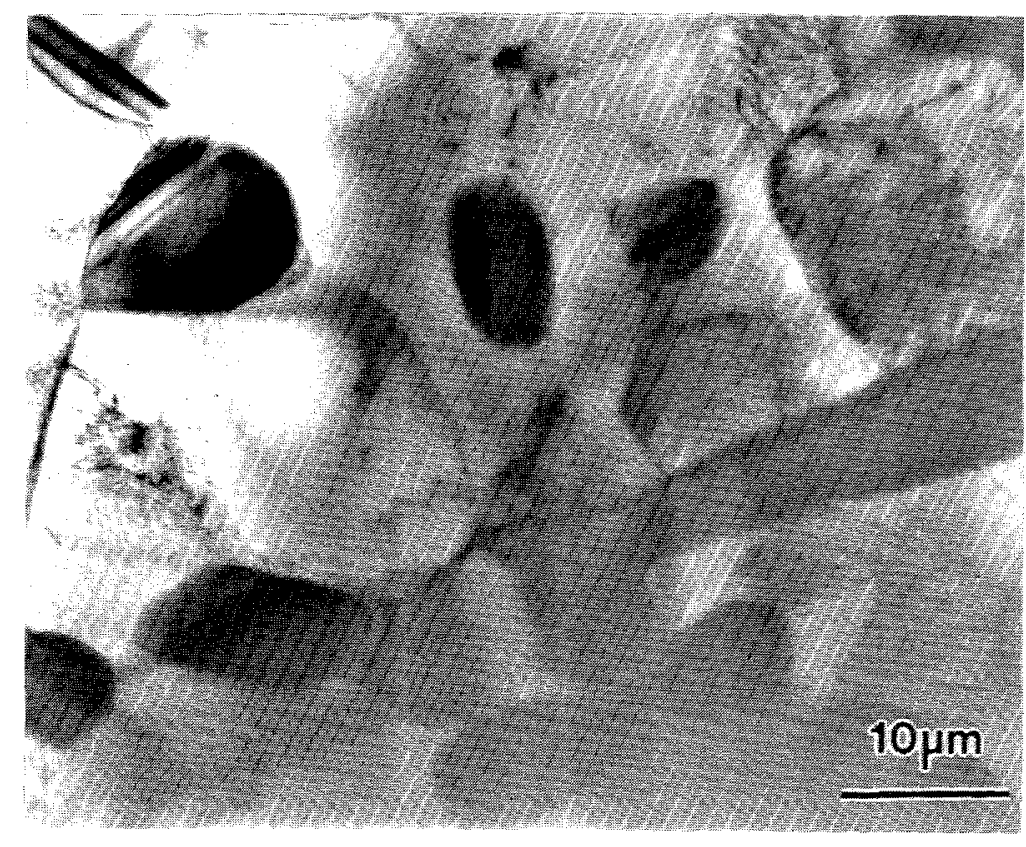

Fig. 4. TEM micrograph of CN-85 (Cr-Nb-1.5Al-5X1$4 \mathrm{X} 2$ ) hot extruded at $1480^{\circ} \mathrm{C}$.

Table 1. Partitioning of Alloying Additions in CN Alloys* as Determined by EDS/TEM

\begin{tabular}{lcc}
\hline \multicolumn{1}{c}{ Alloy (at. \%) } & $\begin{array}{c}\mathrm{Cr}_{2} \mathrm{Nb} \text { Phase } \\
\text { (at. \%) }\end{array}$ & $\begin{array}{c}\text { Cr-rich Matrix } \\
\text { (at. \%) }\end{array}$ \\
\hline CN-80: & & \\
Cr-12Nb-1.5Al-6X1 & $\mathrm{Nb}=33$ & $\mathrm{Nb}=1$ \\
& $\mathrm{Cr}=59$ & $\mathrm{Cr}=90$ \\
& $\mathrm{X} 1=6$ & $\mathrm{X} 1=8$ \\
& $\mathrm{Al}=2$ & $\mathrm{Al}=1$ \\
\hline $\mathrm{CN}-85:$ & & \\
$\mathrm{Cr}-6 \mathrm{Nb}-1.5 \mathrm{Al}-5 \mathrm{X} 1-4 \mathrm{X} 2$ & $\mathrm{Nb}=32$ & $\mathrm{Nb}=1$ \\
& $\mathrm{Cr}=51$ & $\mathrm{Cr}=90$ \\
& $\mathrm{X} 1=7$ & $\mathrm{X} 1=6$ \\
& $\mathrm{X} 2=10$ & $\mathrm{Al}=1.5$ \\
$\mathrm{CN}-87:$ & $\mathrm{Al}=0$ & \\
$\mathrm{Cr}-8 \mathrm{Nb}-1.5 \mathrm{Al}-5 \mathrm{X} 1-4 \mathrm{X} 2-20 \mathrm{X} 4$ & & $\mathrm{Nb}=0.4$ \\
& $\mathrm{Nb}=27$ & $\mathrm{Cr}=73.5$ \\
& $\mathrm{Cr}=27$ & $\mathrm{X} 2=2.3$ \\
& $\mathrm{X} 1=10$ & $\mathrm{X} 4=16.5$ \\
& $\mathrm{X} 2=10$ & $\mathrm{Al}=2.5$ \\
\hline
\end{tabular}

*The alloys were fabricated by hot extrusion at $1480^{\circ} \mathrm{C}$ and annealed for 1 to $3 \mathrm{~d}$ at $1200^{\circ} \mathrm{C}$. 


\section{TENSILE PROPERTIES}

Button-type tensile specimens with gage dimensions $0.31 \mathrm{~cm}$ diam $\times 0.95 \mathrm{~cm}$ long were machined by electro-discharge machining, followed by grinding. The tensile specimens were polished by "0"-grade Emery paper and tested in an Instron testing machine at room temperature in air and at $1200^{\circ} \mathrm{C}$ in vacuum at a crosshead speed of $0.25 \mathrm{~cm} / \mathrm{min}$. Since the tensile properties are sensitive to defects in the alloys, the $\mathrm{CN}$ alloys at room temperature were tested using different fabrication conditions to show the defect effect. Table 2 summarizes the tensile results for $\mathrm{CN}$ alloys in as-cast, directionally solidified, hot-isostatically pressed (HIPped), and hot extruded conditions. Note that all the specimens were annealed 1 to $3 \mathrm{~d}$ at $1200^{\circ} \mathrm{C}$ prior to tensile testing.

The alloy $\mathrm{Cr}-5.6 \mathrm{Nb}-1.5 \mathrm{Al}-6 \mathrm{X} 1$ prepared by arc melting showed a fracture strength at room temperature of $143 \mathrm{MPa}$. The fracture strength increased to $294 \mathrm{MPa}$ when the alloy was prepared by directional solidification via levitation-zone remelting at the University of Tennessee. The strength further increased to $399 \mathrm{MPa}$ when the arc-cast material was HIPped at $1480^{\circ} \mathrm{C}$ at $413 \mathrm{MPa}$ (60 ksi). HIPping was used to reduce cast defects in the $\mathrm{CN}$ alloys. The best fracture strength at room temperature was obtained for a specimen produced by hot extrusion at $1480^{\circ} \mathrm{C}$, which supposedly further reduced cast defects and refined the cast microstructure in $\mathrm{CN}$ alloys. A fracture strength as high as $548 \mathrm{MPa}$ was obtained for hotextruded $\mathrm{Cr}-12 \mathrm{Nb}-1.5 \mathrm{Al}-6 \mathrm{X} 1$ (CN-80).

At $1200^{\circ} \mathrm{C}$, the $\mathrm{CN}$ alloys exhibited significant plastic deformation in tension, with $23 \%$ elongation for $\mathrm{CN}-80$, which also had excellent strength at this temperature (see Table 2). For comparison, the strength of Ni-base superalloys, the state-of-the-art high-temperature materials, drops to almost nil at $1200^{\circ} \mathrm{C}$. The strength appeared to increase with the niobium concentration (or the amount of the $\mathrm{Cr}_{2} \mathrm{Nb}$ phase). The data suggest that alloying with $2 \%$ $\mathrm{X} 3$ significantly increases the strength of $\mathrm{CN}$ alloys at $1200^{\circ} \mathrm{C}$.

The fracture mode of $\mathrm{CN}-80$ was examined by scanning electron microscopy (SEM). The alloy showed a mixture of both brittle cleavage fracture and intergranular fracture at room temperature. On the other hand, it exhibited a ductile fracture with a dimple appearance at $1200^{\circ} \mathrm{C}$. It is known that Cr-based alloys can be embrittled by as little as $100 \mathrm{ppm}$ (or less) of nitrogen or oxygen. ${ }^{12,13}$ In order to detect segregation of these interstitial elements in $\mathrm{CN}$-alloys, $\mathrm{CN}-80$ was fractured in an ultra-high vacuum and analyzed by Auger electron spectroscopy (AES). Limited analyses gave no indication of nitrogen or oxygen segregated to grain-boundary facets or cleavage planes in this alloy. 
Table 2. Effect of Processing and Alloy Composition on Tensile Properties of CN Alloys

\begin{tabular}{|c|c|c|c|c|}
\hline $\begin{array}{c}\text { Alloy } \\
\text { Composition } \\
\end{array}$ & Processing* & $\begin{array}{c}\text { Fracture } \\
\text { Strength } \\
(\mathrm{MPa}) \\
\end{array}$ & $\begin{array}{l}\text { Yield } \\
\text { Strength } \\
(\mathrm{MPa}) \\
\end{array}$ & $\begin{array}{c}\text { Elongation } \\
(\%)\end{array}$ \\
\hline \multicolumn{5}{|c|}{$\underline{\text { Room Temperature }}$} \\
\hline $\mathrm{Cr}-5.6 \mathrm{Nb}-1.5 \mathrm{Al}-6 \mathrm{X} 1$ & $\mathrm{AM}$ & 143 & & \\
\hline $\mathrm{Cr}-5.6 \mathrm{Nb}-1.5 \mathrm{Al}-6 \mathrm{X} 1$ & DS & 294 & & \\
\hline $\mathrm{Cr}-5.6 \mathrm{Nb}-1.5 \mathrm{Al}-6 \mathrm{X} 1$ & HIP & 399 & & \\
\hline $\begin{array}{l}\text { Cr-6.0Nb-1.5Al-5X1-4X2 } \\
\text { (CN-90) }\end{array}$ & $\mathrm{HE}$ & 435 & & \\
\hline $\begin{array}{l}\mathrm{Cr}-12 \mathrm{Nb}-1.5 \mathrm{Al}-6 \mathrm{X} 1 \\
(\mathrm{CN}-80)\end{array}$ & $\mathrm{HE}$ & 548 & & \\
\hline \multicolumn{5}{|c|}{$1200^{\circ} \mathrm{C}$} \\
\hline $\begin{array}{l}\text { Cr-6.0Nb-1.5Al-5X1-4X2- } \\
2 \mathrm{X} 3 \\
(\mathrm{CN}-90)\end{array}$ & $\mathrm{HE}$ & 384 & 302 & 13.4 \\
\hline $\begin{array}{l}\mathrm{Cr}-10 \mathrm{Nb}-1.5 \mathrm{Al}-5 \mathrm{X} 1-4 \mathrm{X} 2 \\
(\mathrm{CN}-89)\end{array}$ & $\mathrm{HE}$ & 269 & 238 & 1.6 \\
\hline $\begin{array}{l}\text { Cr-12Nb-1.5Al-6X1 } \\
(\mathrm{CN}-80)\end{array}$ & $\mathrm{HE}$ & 388 & 290 & 23.0 \\
\hline
\end{tabular}

\section{FRACTURE TOUGHNESS}

The fracture toughness of CN-87 (Cr-8Nb-1.5Al-5X1-4X2-20X4) hot extruded at $1480^{\circ} \mathrm{C}$ was determined by three-point bend testing of Chevron-notched specimens. The alloy exhibited a fracture toughness of $7.6 \mathrm{MPa} \vee \mathrm{m}$ at room temperature. The toughness increased substantially with temperature, to 18.3 and $24.4 \mathrm{MPa} \sqrt{\mathrm{m}}$ at 800 and $1000^{\circ} \mathrm{C}$, respectively. The alloy was so ductile at $1200^{\circ} \mathrm{C}$ that it could not be fractured by bend testing. The fracture toughness of $\mathrm{CN}-87$ at room temperature is comparable to that of a $\mathrm{Cr}_{2} \mathrm{Hf} / \mathrm{Cr}$ alloy reported recently by Kumar and Miracle. ${ }^{12}$ Figure 5 shows the crack growth modes in $\mathrm{CN}-87$ at room temperature and $800^{\circ} \mathrm{C}$. The alloy exhibited a mixed fracture mode at room temperature (Fig. 5a) and a more ductile fracture with $\mathrm{Cr}$-rich patches necking down to a chisel point at $800^{\circ} \mathrm{C}$ (Fig. $5 \mathrm{~b}$ ). 


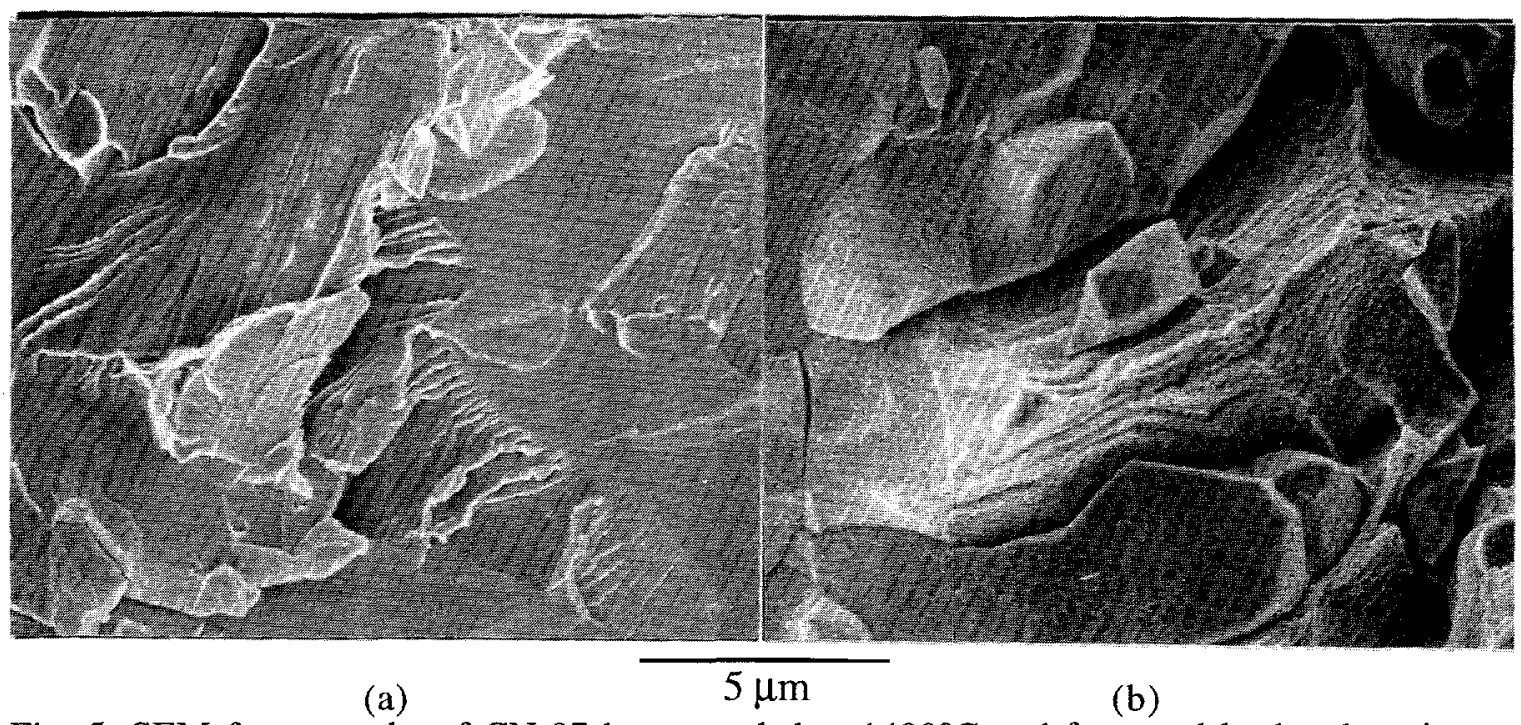

Fig. 5. SEM fractographs of $\mathrm{CN}-87$ hot extruded at $1480^{\circ} \mathrm{C}$ and fractured by bend testing at (a) room temperature and (b) $800^{\circ} \mathrm{C}$.

\section{HIGH-TEMPERATURE OXIDATION BEHAVIOR}

It has been previously demonstrated ${ }^{9}$ that the presence of significant concentrations of element $\mathrm{X} 1$ substantially increased the isothermal oxidation rates and spallation susceptibilities of $\mathrm{Cr}-\mathrm{Cr}_{2} \mathrm{Nb}$ alloys, while the addition of $\mathrm{X} 2$ completely offset these deleterious effects. The presence of this latter element resulted in the best overall oxidation behavior of all $\mathrm{Cr}-\mathrm{Cr}_{2} \mathrm{Nb}$ compositions. ${ }^{9}$ The effects of $\mathrm{X} 2$ were manifested as relatively low weight gains, substantially reduced scale cracking and spallation, and elimination of the dependence of oxidation behavior on niobium content (that is, on the relative amounts of the Cr-rich and eutectic phases). Its beneficial influence was attributed to improvement in the oxidation resistance of the $\mathrm{Cr}$-rich regions (despite its partitioning to the $\mathrm{Cr}_{2} \mathrm{Nb}$ phase), ${ }^{9}$ which otherwise showed preferential susceptibility to degradation upon exposure to hightemperature air. ${ }^{8,14}$ Recent work has shown that the positive effect of X2 on oxidation resistance is maintained under the more severe oxidation conditions associated with thermal cycling. This is shown by the cyclic oxidation results in Fig. 6: the alloy containing X2 (CN87 , see Table 1) showed relatively low weight gains and significantly improved spallation resistance (as characterized by the weight of spalled material) when compared to a $\mathrm{Cr}-\mathrm{Cr}_{2} \mathrm{Nb}$ composition containing $\mathrm{X} 1(\mathrm{CN}-80)$.

Element X2 continued to impart a beneficial effect on the rate of isothermal weight gain and spallation resistance up to $1100^{\circ} \mathrm{C}$, as shown by comparison of the curves for uncoated $\mathrm{CN}-80$ and -87 in Fig. $7 \mathrm{a}$ and $\mathrm{b}$, respectively. However, the oxidation rate at this temperature 


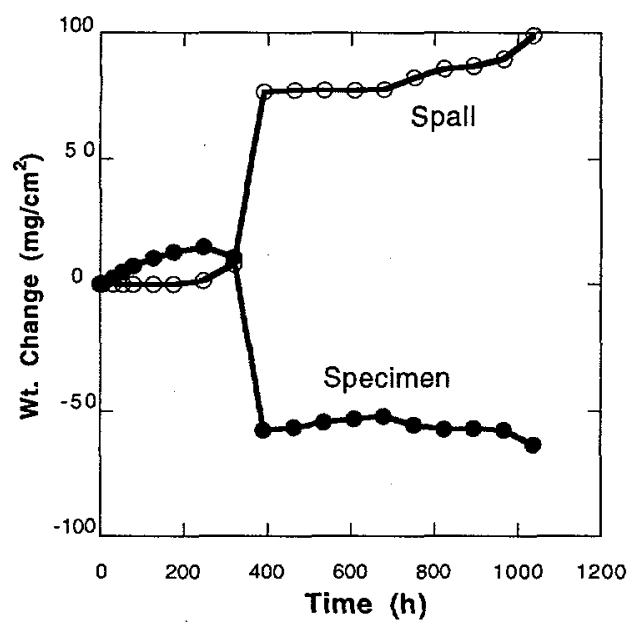

(a)

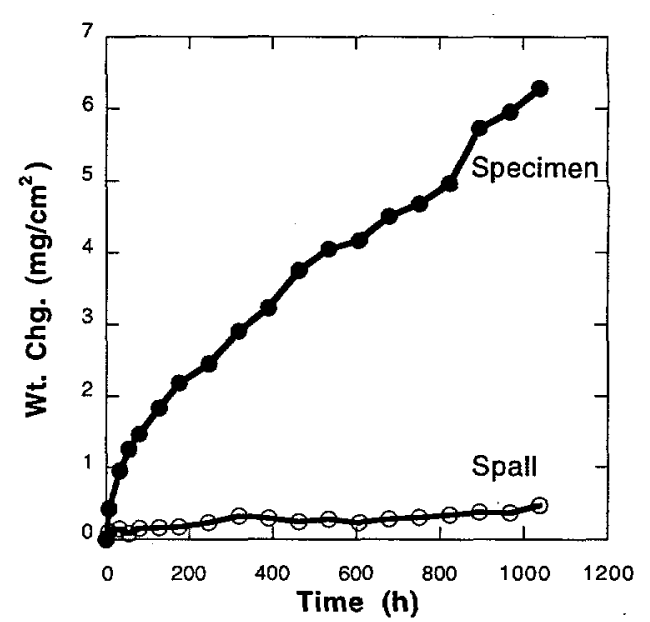

(b)

Fig. 6. Weight change versus time for specimens cyclically oxidized in air at $950^{\circ} \mathrm{C}$. Each point represents one thermal cycle. Closed and open symbols represent weight changes of the specimen and spalled material, respectively. (a) $\mathrm{CN}-80$ (b) $\mathrm{CN}-87$

was still relatively high (as it is for all chromia-formers). Therefore, it was deemed necessary to examine the possibility of using coatings to reduce the oxidization at higher temperatures. To this end, some preliminary experiments were conducted by depositing a germania-doped silicide coating on $\mathrm{CN}-80$ and $\mathrm{CN}-87$ by pack cementation at The Ohio State University. ${ }^{15}$ The details of the coating process for these alloys are described elsewhere. ${ }^{16}$ In isothermal microbalance exposures in dry air, specimens coated in this manner exhibited very low weight gains at 950 and $1100^{\circ} \mathrm{C}$ (Fig. 7). The oxidation rate was essentially controlled by the coatings as there was little difference between the $950^{\circ} \mathrm{C}$ gravimetric results for coated $\mathrm{CN}-80$ and $\mathrm{CN}-87$ (compare Fig $7 \mathrm{a}$ with $7 \mathrm{~b}$ ) despite the significant differences in their oxidation rates when uncoated.

While these initial results with coated $\mathrm{Cr}-\mathrm{Cr}_{2} \mathrm{Nb}$ are quite encouraging, particularly as the coatings have not yet been optimized for these substrates, ${ }^{16}$ the influence of thermal stresses produced during cyclic oxidation on the integrity and adherence of these surface layers, and of the oxide scales that formed on them, must be assessed in some detail. In one microbalance experiment, the exposure was twice interrupted by cooling to room temperature with subsequent reheating to the oxidation temperature. The results, shown in Fig. 8, indicated an abrupt weight gain (probably due to cracking of the scale on the coating) after a thermal cycle, but a rapid healing of any cracks such that the same low oxidation rate was quickly reestablished. While final conclusions regarding the utility of this approach for 


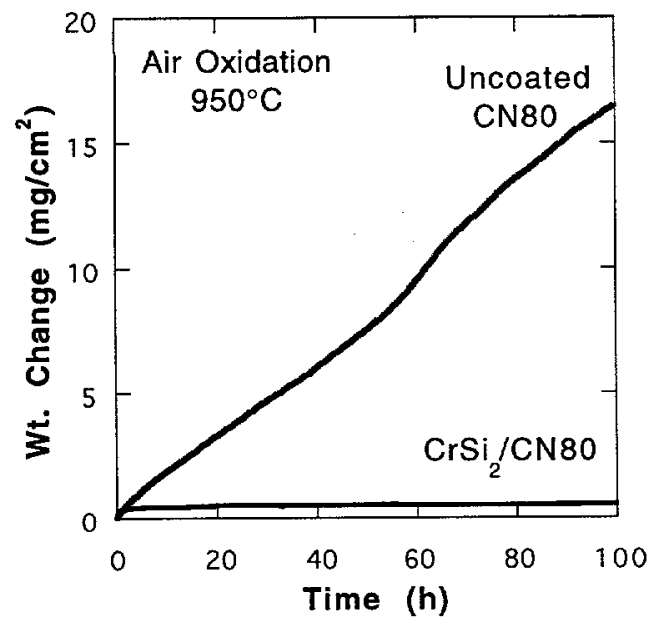

(a)

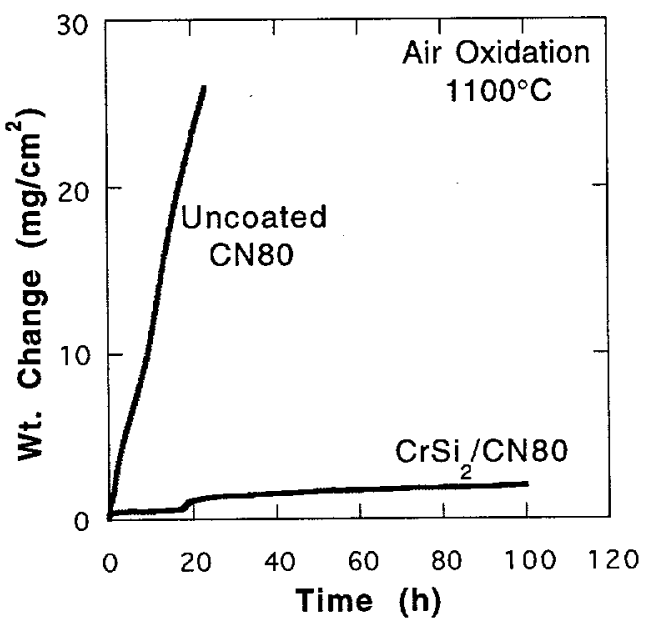

(c)

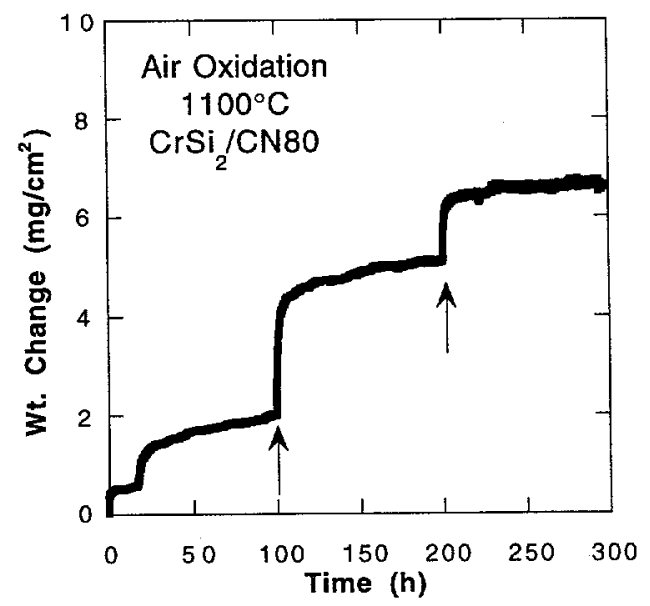

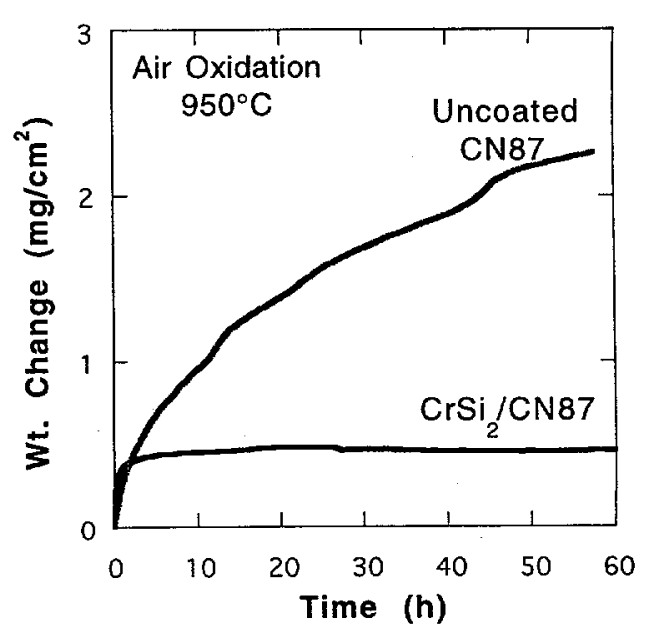

(b)

Fig. 7. Weight change versus time for coated and uncoated $\mathrm{Cr}-\mathrm{Cr}_{2} \mathrm{Nb}$ alloys isothermally exposed to dry, flowing air at elevated temperatures. The silicide coating was applied by a pack cementation process. (a) $\mathrm{CN}-80,950^{\circ} \mathrm{C}$. (b) $\mathrm{CN}-87,950^{\circ} \mathrm{C}$. (c) $\mathrm{CN}-80,1100^{\circ} \mathrm{C}$.
Fig. 8. Weight change versus time for silicide coated $\mathrm{CN}-80$ isothermally oxidized in air at $1100^{\circ} \mathrm{C}$. Arrows indicated times at which specimen was cooled to room temperature and then reheated to the exposure temperature. 
corrosion protection of these alloys await more rigorous cyclic oxidation testing and coating optimization, the present results indicate that such surface treatments offer excellent promise as effective routes to oxidation resistance for temperatures (such as $1100^{\circ} \mathrm{C}$ ) where the superior strength of $\mathrm{Cr}-\mathrm{Cr}_{2} \mathrm{Nb}$ alloys can be exploited.

\section{SUMMARY AND CONCLUSIONS}

Two-phase $\mathrm{Cr}-\mathrm{Cr}_{2} \mathrm{Nb}$ alloys (designated as $\mathrm{CN}$ alloys) were prepared by arc melting, followed by directional solidification, HIPping, or hot extrusion at 1450 to $1500^{\circ} \mathrm{C}$. The secondary processing was used to reduce cast defect structures in $\mathrm{CN}$ alloys.

The microstructure of $\mathrm{CN}$ alloys containing 6 to $12 \% \mathrm{Nb}$ depended strongly on alloying addition, heat treatment, and material processing. Hot extrusion at $1480^{\circ} \mathrm{C}$ was most effective in reducing as-cast defects and refining the cast $\mathrm{Cr}-\mathrm{Cr}_{2} \mathrm{Nb}$ eutectic structure.

Several beneficial alloying elements have been identified. Element X1 refined the coarse eutectic structure but reduced oxidation resistance. $\mathrm{X} 2$ substantially improved both isothermal and cyclic oxidation resistance. $\mathrm{X} 3$ strengthened $\mathrm{CN}$ alloys at high temperatures. $\mathrm{X} 5$ is used to control the morphology of the eutectic structure.

Tensile properties were sensitive to defects in $\mathrm{CN}$ alloys. The best results were obtained from hot-extruded $\mathrm{CN}-80$ (Cr-12Nb-1.5Al-6X1) which showed a fracture strength of $548 \mathrm{MPa}$ at room temperature, and an ultimate tensile strength of $388 \mathrm{MPa}$, with an elongation of $23 \%$, at $1200^{\circ} \mathrm{C}$.

The alloy $\mathrm{CN}-87$ fabricated by hot extrusion at $1480^{\circ} \mathrm{C}$ showed a fracture toughness of 7.6 MPa $\sqrt{\mathrm{m}}$ at room temperature. The toughness increased substantially with temperature and reached $24.4 \mathrm{MPa} \sqrt{\mathrm{m}}_{\mathrm{m}}$ at $1000^{\circ} \mathrm{C}$.

A silicide coating applied by a pack cementation process substantially improved the oxidation resistance of the $\mathrm{Cr}-\mathrm{Cr}_{2} \mathrm{Nb}$ alloys at 950 and $1100^{\circ} \mathrm{C}$. Such surface layers offer the potential to afford corrosion resistance to these alloys at temperatures (such as $1100^{\circ} \mathrm{C}$ ) at which thermally grown oxides on $\mathrm{CN}$ compositions are not protective and, thus, may allow the superior strength of $\mathrm{Cr}-\mathrm{Cr}_{2} \mathrm{Nb}$ alloys to be exploited.

\section{ACKNOWLEDGMENTS}

The authors thank C. G. McKamey and S. J. Pawel for their reviews of the manuscript. This research was sponsored by the Fossil Energy Advanced Research and Technology Development (AR\&TD) Materials Program, U. S. Department of Energy, under contract DEAC05-84OR21400 with Martin Marietta Energy Systems, Inc. 


\section{REFERENCES}

1. F. Laves, p. 124 in Theory of Alloy Phases. American Society for Metals, Metals Park, $\mathrm{OH}, 1956$, .

2. D. J. Thoma and J. H. Perepezko, Mat. Sci. and Eng. A156, 97-108 (1992).

3. H. J. Goldschmidt and J. A. Brand, J. Less-Common Met. 3, 44 (1961).

4. T. B. Massalski, J. L. Murray, L. H. Bennett, and H. Baker (eds.), Binary Alloy Phase Diagram, American Society for Metals, Metals Park, OH, 1986.

5. A. I. Taub and R. L. Fleischer, Science 243, 616 (1989).

6. C. T. Liu, pp. 375-383 in Proc. 6th Annual Conf. Fossil Energy Materials, N. C. Cole and R. R. Judkins (comp.), U. S. Department of Energy, July 1992.

7. C. T. Liu, J. A. Horton, and C. A. Carmichael, pp. 297-307, in Proc. 7th Annual Conf. on Fossil Energy Materials, N. C. Cole and R. R. Judkins (comp.), U. S. Department of Energy, July 1993.

8. P. F. Tortorelli, L. J. Carsen, and J. H. DeVan, pp. 309-318 in Proc. 7th Annual Conf. on Fossil Energy Materials, N. C. Cole and R. R. Judkins (comp.), U. S. Department of Energy, July 1993.

9. P. F. Tortorelli and J. H. DeVan, pp. 391-400 in Proc. 8th Annual Conf. on Fossil Energy Materials, N. C. Cole and R. R. Judkins (comp.), U. S. Department of Energy, August 1994.

10. C. T. Liu, J. A. Horton, and C. A. Carmichael, pp. 377-390 in Proc. 8th Annual Conf. on Fossil Energy Materials, N. C. Cole and R. R. Judkins (comp.), U. S. Department of Energy, August 1994..

11. M. Takeyama and C. T. Liu, Mat. Sci. and Eng. A132, 61 (1991).

12. K. S. Kumar and D. B. Miracle, Intermetallics 2, 257-274 (1994).

13. H. L. Wain, F. Henderson, S.T.M. Jonstone, J. Inst. Met. 83, 1954-55 (1993).

14. P. F. Tortorelli and J. H. DeVan, "The Nature of Scales Grown on Binary $\mathrm{Cr}-\mathrm{Nb}$ Alloys," pp. 229-236 in Proc. Symp. on Oxide Films on Metals and Alloys, B. R. MacDougall, R. S. Alwitt, and T. A. Ramanarayanan (eds.), Proceedings Vol. 92-22, The Electrochemical Society, 1992.

15. M. A. Harper and R. A. Rapp, pp. 379-86 in Heat Resistant Materials, K. Natesan and D. J. Tillack, (eds.), ASM International, Materials Park, OH, 1991.

16. Y-R. He and R. A. Rapp, "Pack Cementation Cr-Al Coating of Steels and Ge-Doped Silicide Coating of $\mathrm{Cr}-\mathrm{Nb}$ Alloy," these proceedings. 


\subsection{DEVELOPMENT OF IRON ALUMINIDES}

\section{S. Viswanathan, V. K. Sikka, V. K. Andleigh, and C. G. McKamey \\ INTRODUCTION}

The primary reason for the poor room-temperature ductility of $\mathrm{Fe}_{3} \mathrm{Al}$-based alloys is generally accepted to be environmental embrittlement due to hydrogen produced by the reaction of aluminum with water vapor present in the test atmosphere [1]. In the as-cast condition, another possible reason for the low room-temperature ductility is the large grain size $(0.5$ to $3 \mathrm{~mm})$ of the cast material [2]. While recent studies on iron aluminides in the wrought condition have led to higher room-temperature ductility and increased hightemperature strength [1], limited studies have been conducted on iron aluminides in the ascast condition. The purpose of this study was to induce grain refinement of the as-cast alloy through alloying additions to the melt and study the effect on room-temperature ductility as measured by the strain corresponding to the maximum stress obtained in a three-point bend test. A base charge of $\mathrm{Fe}-28 \% \mathrm{Al}-5 \% \mathrm{Cr}$ alloy was used; as in previous studies this ternary alloy exhibited the highest tensile ductility of several alloys tested [2].

Iron aluminide alloys are being considered for many structural uses, especially for applications where their excellent corrosion resistance is needed. Several alloy compositions developed at ORNL have been licensed to commercial vendors for development of scale-up procedures. With the licensees and other vendors, several applications for iron aluminides are being pursued.

\section{DISCUSSION OF CURRENT ACTIVITIES}

The Effect of Grain Refinement on the Room-Temperature Ductility of As-Cast $\mathrm{Fe}_{3} \mathrm{Al}-\mathrm{Based}$ Alloys

As part of a study on wrought alloys, a large number of cast alloy samples with a variety of alloying additions had been produced in the form of 450-g chill-cast ingots [3]. Samples were obtained close to the hot-top sections of these ingots; were polished and then swab-etched using a solution of $25 \mathrm{~mL}$ acetic acid, $15 \mathrm{~mL}$ nitric acid, $15 \mathrm{~mL}$ hydrochloric acid, and $5 \mathrm{~mL}$ water; and finally, were examined under an optical microscope. In this preliminary screening, only samples containing titanium and boron showed evidence of grain refinement; samples containing other additions (including $\mathrm{Ce}, \mathrm{Hf}, \mathrm{Mg}, \mathrm{Mn}, \mathrm{Mo}, \mathrm{Nb}, \mathrm{Si}, \mathrm{V}, \mathrm{Y}$, and $\mathrm{Zr}$ ) did not show any evidence of grain refinement. Consequently, the effects of titanium and boron were examined in detail in this study. 
For the grain-refinement study, approximately $10 \mathrm{~kg}$ of a base charge material of Fe$28 \% \mathrm{Al}-5 \% \mathrm{Cr}$ alloy was prepared by melting elemental materials in air in an induction furnace under an argon blanket, and cast into a graphite mold to produce rods of approximately $35 \mathrm{~mm}$ diam. and $200 \mathrm{~mm}$ length. The rods were ground to $28 \mathrm{~mm}$ diam. and cut to provide cylinders consisting of approximately $300 \mathrm{~g}$ of base charge material. These cylinders were subsequently melted in an induction furnace specially constructed for this study, alloyed with a variety of inoculants designed to promote grain refinement, and cast into a preheated graphite mold to produce 30 by 50 by $30 \mathrm{~mm}$ ingots. Table 1 indicates nominal compositions for the heats discussed in this paper. A mold preheat temperature of $400^{\circ} \mathrm{C}$ was used throughout the study. Although the pouring temperature of the metal was not measured, it is estimated that it was in the range of 1500 to $1600^{\circ} \mathrm{C}$ since the liquidus temperature of $\mathrm{Fe}_{3} \mathrm{Al}$-based alloys is approximately $1470^{\circ} \mathrm{C}$. Also, although an argon blanket was used during melting, an oxide layer formed on the melt surface, and a preheated graphite rod was quickly inserted into the melt prior to pouring to break up the surface oxide layer and allow a smooth pour. Figure 1 illustrates the graphite mold used in the study.

Ingots were sectioned to obtain metallography and bend test specimens. Metallography specimens were polished, swab-etched, and examined under an optical microscope; ingot compositions were subsequently checked by energy dispersive spectroscopy (EDS). In cases where there was evidence of grain refinement, vertical sections were

Table I. Nominal compositions of cast ingots in grain-refinement study of $\mathrm{Fe}_{3} \mathrm{Al}$ alloys

\begin{tabular}{||c|c|c|c|c|c|c||}
\hline \hline & \multicolumn{7}{|c||}{ Composition (at.\%) } \\
\hline Heat No. & Fe & Al & Cr & Ti & C & B \\
\hline GR-07 & Balance & 28.0 & 5.0 & & & \\
GR-09 & Balance & 28.0 & 5.0 & 1.0 & 0.1 & \\
GR-10 & Balance & 28.0 & 5.0 & 1.0 & 0.1 & 0.12 \\
GR-11 & Balance & 28.0 & 5.0 & 2.0 & & \\
GR-12 & Balance & 28.0 & 5.0 & 1.0 & 0.1 & 0.52 \\
GR-19 & Balance & 28.0 & 5.0 & 1.5 & & \\
GR-20 & Balance & 28.0 & 5.0 & & & 0.12 \\
GR-21 & Balance & 28.0 & 5.0 & & & 0.52 \\
GR-26 & Balance & 28.0 & 5.0 & & & \\
GR-27 & Balance & 28.0 & 5.0 & 1.0 & 0.1 & 0.02 \\
GR-28 & Balance & 28.0 & 5.0 & & & 0.02 \\
GR-30 & Balance & 28.0 & 5.0 & & 0.1 & 0.02 \\
GR-34 & Balance & 28.0 & 5.0 & 1.0 & & 0.02 \\
GR-36 & Balance & 28.0 & 5.0 & 1.5 & & \\
\hline \hline
\end{tabular}




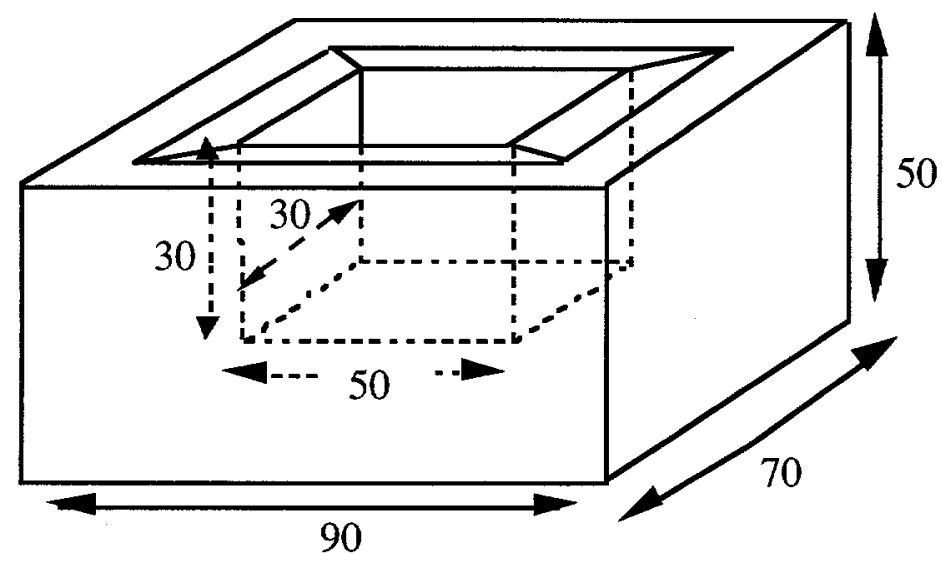

Fig. 1. Graphite mold used in grain-refinement studies of $\mathrm{Fe}_{3} \mathrm{Al}$ (dimensions in $\mathrm{mm}$ ).

macroetched to reveal ingot macrostructure. Two bars of 4 by $4-\mathrm{mm}$ cross-section and 40 $\mathrm{mm}$ length were electro-discharge-machined from locations toward the bottom of the ingot. After machining, bar edges were ground lightly on 600 grit silicon carbide paper, and the bars were electropolished in a solution of 7 parts methanol and 1 part sulfuric acid at $7.5 \mathrm{~V}$ for about $100 \mathrm{~s}$. Two bend test specimens of $20 \mathrm{~mm}$ length were typically obtained from each bar. Specimens were ultrasonically cleaned for $3 \mathrm{~min}$ and washed in acetone before testing. A gauge length of $10 \mathrm{~mm}$ was used in the three-point bend test configuration. The stress and strain were calculated from the equations

$$
\sigma=3 P L / 2 w t^{2}
$$

and

$$
\varepsilon=6 t y / L^{2}
$$

where $\sigma=$ stress, $\varepsilon=$ strain, $P=$ load, $y=$ displacement, $L=$ gauge length, $w=$ specimen width, and $t=$ specimen thickness.

The base charge material produced an ingot consisting entirely of columnar grains. The addition of $1 \% \mathrm{Ti}, 0.1 \% \mathrm{C}$, and $0.12 \% \mathrm{~B}$ produced some grain refinement in the center of the ingot, although a columnar zone was seen along the edge of the ingot. The addition of $0.52 \% \mathrm{~B}$ provided a marginal increase in grain refinement in the center of the ingot, while the addition of $2 \% \mathrm{Ti}$ provided extensive grain refinement over the entire ingot. Additions of titanium at levels less than $1 \%$ did not produce grain refinement, and additions of other alloying elements at levels up to $2 \%$ also did not have an effect. It must be noted that because of the high thermal gradients expected in the solidifying metal due to the use of a small graphite mold, preferentially giving rise to columnar grains, this test provides a very severe test of grain-refinement efficacy. 
Figure 2 shows the results of the three-point bend tests. Figure 2(a) shows the maximum stress values obtained, and Fig. 2(b) shows the strains corresponding to the maximum stress. For each case, the values obtained may be compared to that obtained for the base charge of $\mathrm{Fe}-28 \% \mathrm{Al}-5 \% \mathrm{Cr}$ alloy. The trends obtained for maximum stress and strain are similar and indicate that the addition of titanium or carbon alone serve to embrittle the material, lowering both the stress and strain values obtained. The addition of both titanium and carbon produced the lowest values of stress and strain at failure. The addition of boron improved both the maximum stress and the strain obtained, although ductility was somewhat affected as boron was increased. The effect of boron on the strength of the alloy may also be the reason that boron decreases the weldability of iron-aluminide alloys. Interestingly, the effects of boron and carbon seemed to offset each other with respect to the maximum stress obtained; carbon-containing alloys seemed to require more boron to produce the same strength levels as alloys containing no carbon. Boron also had a strong effect on the maximum strain obtained, inasmuch as the presence of any boron in the alloy provided moderate ductility at least equal to the base charge material, even in the presence of carbon. The maximum ductility was obtained in an alloy containing $1 \% \mathrm{Ti}, 0.1 \% \mathrm{C}$, and $0.52 \% \mathrm{~B}$, although this value was almost identical to that obtained for the alloy containing $0.02 \%$ boron alone.

The results of the study clearly establish the grain-refinement propensity of titanium and the effect of boron on ductility, although titanium also serves to embrittle the material. In general, the addition of alloying elements other than boron invariably served to decrease both the maximum stress and the maximum strain obtained, indicating that for as-cast $\mathrm{Fe}_{3} \mathrm{Al}$ based alloys, the addition of alloying elements designed to serve as inoculants is likely to have a negative effect on ductility, even when grain refinement is obtained.

Industrial Interactions on $\mathrm{Fe}_{3} \mathrm{Al}$-Based Alloys

In this reporting period there have been strong interaction with four industrial partners on $\mathrm{Fe}_{3} \mathrm{Al}$-based alloys. Each is briefly described below.

\section{Rapid Technologies, Inc. Newnan, GA}

The $\mathrm{Fe}_{3} \mathrm{Al}$-based alloy FA-129 with added zirconium has been identified as a material for rails in walking beam furnaces. The major advantages of the material are its high melting point and good high-temperature oxidation resistance up to $1375^{\circ} \mathrm{C}$. The oxidation resistance data are based on two-week-long isothermal oxidation tests at $1375^{\circ} \mathrm{C}$ conducted at ORNL. Based on these properties, Rapid Technologies, Inc. has procured 20 rails from 


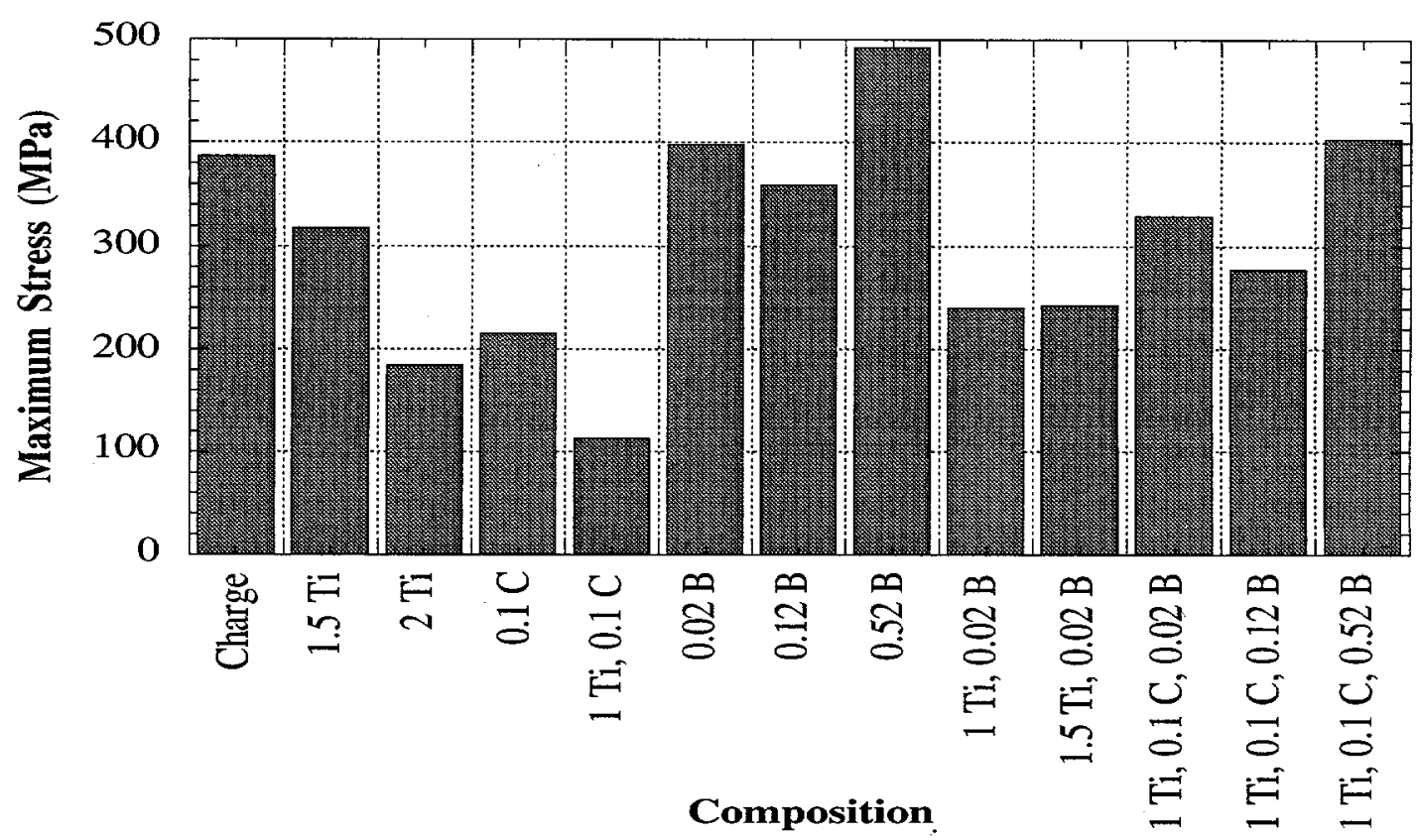

(a)

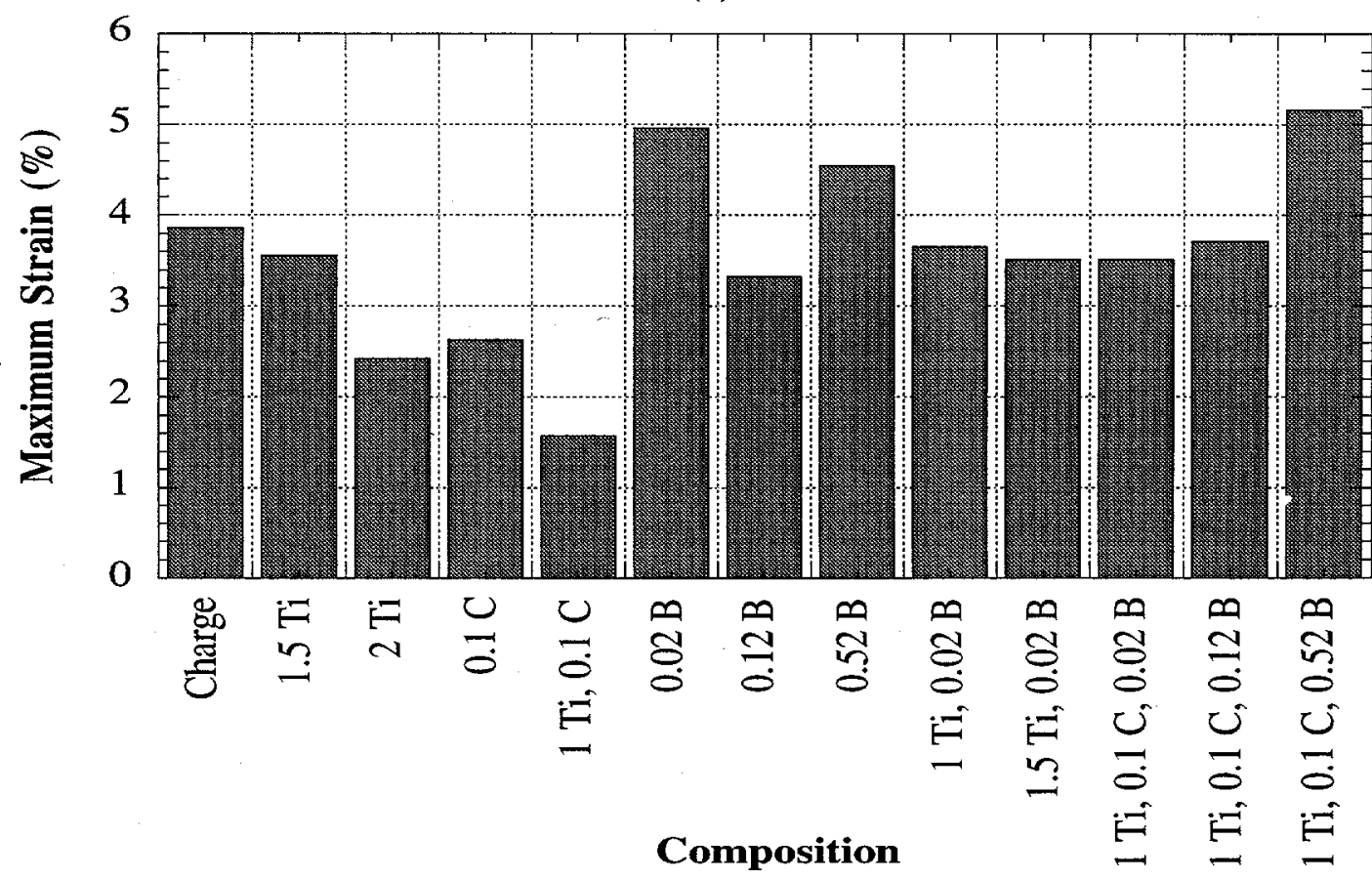

(b)

Fig. 2. Results of three-point bend tests: (a) maximum stress; (b) maximum strain. 
Manufacturing Sciences Corp. in Oak Ridge, TN. The rails were put into service in a walkingbeam furnace during the month of April 1994. ORNL worked very closely with Rapid Technologies, Inc. in alloy selection, the proposed method of manufacturing, chemical analyses, and generation of property data. The rails performed only for a short period of time $(\approx 24 \mathrm{~h})$ before creep distortion, as a result of the pressure exerted by impinging hot gases from the burners, made them unusable. This exercise gave us good experience in commercial manufacture of the $\mathrm{Fe}_{3} \mathrm{Al}$-based alloy. However, its application in the walkingbeam furnace, especially in the hotest end of the furnace, turned out to be unsuccessful because of the limited strength of FA-129 at temperatures exceeding $700^{\circ} \mathrm{C}$.

\section{Manufacturing Sciences Corp, Oak Ridge. TN}

ORNL scientists worked closely with Manufacturing Sciences Corp. in identifying the manufacturing steps for iron aluminide rails. The selected steps include: vacuum induction melting (VIM) of 182-kg (400-lb) heats, casting them into 102-mm-thick (4-in.) slabs, hot rolling them into 19 -mm-thick (0.75 in.) plate, hot shearing into rough dimensions, surface cleaning by acid bath and/or sand blasting, and machining into final shape. A joint effort between ORNL and Manufacturing Science Corp. identified an inexpensive method for directly hot-shearing the saw-tooth pattern into hot-rolled plates of iron aluminide. This method eliminated the need for expensive machining operations. The project with Rapid Technology (described above) ended prior to full implementation of this technology. The slab castings of FA-129 with $\mathrm{Zr}$ of 102 -mm-thickness (4 in.) were procured from Manufacturing Sciences Corp. for processing studies and further testing and evaluation.

\section{Babcock \& Wilcox (B\&W)}

The $\mathrm{B} \& \mathrm{~W}$ company has identified $\mathrm{Fe}_{3} \mathrm{Al}$-based alloys as possible shielding material for applications in boiler plants and incinerators. The shields are typically $3.2 \mathrm{~mm}(0.125$ in.) thick and in the shape of a half tube of $63-\mathrm{mm}(2.5 \mathrm{in}$.) diameter. Three prototypic shields of iron aluminide alloy FA-129 with $\mathrm{Zr}$ were supplied for testing in an incinerator plant in Florida. After some delays one of the shields was tested in the plant for 3 months and removed in February 1995. General observations indicate that the shields worked better than stainless steel ones. The major issue still remaining is the observation of some pitting. $\mathrm{B} \& \mathrm{~W}$ has asked us to supply several additional shields for testing. We have an opportunity to make compositional modifications to minimize the pitting issue. The shields are required by the third week of April, 1995, for meeting the plant shut-down schedule. We are currently working on the composition and plan to supply at least six shields for testing. 


\section{PALL Corp.}

Efforts continued during this period in support of PALL Corp. to resolve issues related to manufacturing of porous sintered metal gas filters. The support to PALL has been a joint effort between Ametek and ORNL. During the last year, Ametek produced wateratomized powder and supplied it to PALL and ORNL. Pall has developed the sintering techniques for this powder, while ORNL has consolidated it, evaluated its microstructure and properties, and compared it to the gas-atomized powder produced earlier by Ametek. The water-atomized powder has sintered significantly better than the gas-atomized powder and provided PALL Corp. the opportunity to introduce the porous filters into the market for various trial tests. The water atomization process not only produces the lower-cost powder, but also the better product. The determination of the mechanical properties of wateratomized powder is near completion and will be reported in forthcoming quarterly reports.

\section{ACKNOWLEDGMENTS}

The authors wish to thank J. D. Vought, B. Whitson, K. Byrd, G. Garner, E. Hatfield, R. Howell, C. Carmichael, and the metallography group for technical support, and H. Payne and the Science and Engineering Research Semester (SERS) Program, U.S. Department of Energy, for supporting one of the authors (V. K. Andleigh).

\section{REFERENCES}

1. C. T. Liu in High Temperature Ordered Intermetallics $\underline{V}$, edited by I. Baker, J. D. Whittenberger, R. Darolia, and M. H. Yoo (MRS Proc. 288, Pittsburgh, PA, 1993) p. 3.

2. S. Viswanathan, C. G. McKamey, P. J. Maziasz, and V. K. Sikka, in Processing. Properties, and Applications of Iron Aluminides, edited by J. H. Schneibel, and M. A. Crimp (The Minerals, Metals, and Materials Society, Warrendale, PA, 1994) pp. 159-169.

3. C. G. McKamey, C. T. Liu, S. A. David, J. A. Horton, D. H. Pierce, and J. J. Campbell, Development of Iron Aluminides for Coal Conversion Systems, ORNL/TM-10793 (Martin Marietta Energy Systems, Inc., Oak Ridge, TN, 1988). 



\title{
2.9 HIGH-STRENGTH IRON ALUMINIDE ALLOYS
}

\author{
C. G. McKamey, Y. Marrero-Santos, ${ }^{\star}$ and P. J. Maziasz
}

\section{INTRODUCTION}

Past studies have shown that binary $\mathrm{Fe}_{3} \mathrm{Al}$ possesses low creep-rupture strength compared to many other alloys, with creep-rupture lives of less than $5 \mathrm{~h}$ being reported for tests conducted at $593^{\circ} \mathrm{C}$ and $207 \mathrm{MPa}$ (ref. 1). The combination of poor creep resistance and low room-temperature tensile ductility due to a susceptibility to environmentallyinduced dynamic hydrogen embrittlement ${ }^{2,3}$ has limited use of these alloys for structural applications, despite their excellent corrosion properties. 4 Improvements in room temperature tensile ductility have been realized mainly through alloying effects, changes in thermomechanical processing to control microstructure, and by control of the specimen's surface condition. 3,5 Ductilities of $10-20 \%$ and tensile yield strengths as high as $500 \mathrm{MPa}$ have been reported.6,7 In terms of creep-rupture strength, small additions of $\mathrm{Mo}, \mathrm{Nb}$, and $\mathrm{Zr}$ have produced significant improvements, but at the expense of weldability and roomtemperature tensile ductility.1,8-11 Recently an alloy containing these additions, designated FA-180, was shown to exhibit a creep-rupture life of over $2000 \mathrm{~h}$ after a heat treatment of $1 \mathrm{~h}$ at $1150^{\circ} \mathrm{C} .12$ This study presents the results of creep-rupture tests at various test temperatures and stresses and discusses the results as part of our effort to understand the strengthening mechanisms involved with heat treatment at $1150^{\circ} \mathrm{C}$.

\section{DISCUSSION OF CURRENT ACTIVITIES}

The alloy composition used in this study was designated FA-180 and has a nominal composition of $\mathrm{Fe}-28 \mathrm{Al}-5 \mathrm{Cr}$ (at.\%) with $0.5 \% \mathrm{Nb}, 0.8 \% \mathrm{Mo}, 0.025 \% \mathrm{Zr}, 0.05 \% \mathrm{C}$, and $0.005 \%$ B. It was prepared by arc-melting and drop-casting into a chilled copper mold. Fabrication to $0.8-\mathrm{mm}$-thick sheet was accomplished by hot-rolling, beginning at $1000^{\circ} \mathrm{C}$ and finishing at $600-650^{\circ} \mathrm{C}$. After a stress relief heat treatment of $1 \mathrm{~h}$ at $700^{\circ} \mathrm{C}$, flat tensile specimens $(0.8 \times 3.18 \times 12.7 \mathrm{~mm})$ were mechanically punched from the rolled sheet. Before testing, the tensile specimens were further annealed in air for $1 \mathrm{~h}$ at $1150^{\circ} \mathrm{C}$ and air cooled. Creep-rupture tests were performed in air at temperatures between 500 and $775^{\circ} \mathrm{C}$ and at stresses of 69 to $379 \mathrm{MPa}(10-55 \mathrm{ksi})$. Minimum creep rates (MCR) were measured as the

\footnotetext{
*Summer student from Emilio R. Delgado High School, Corozal, PR 00783, sponsored by the American Chemical Society's Project SEED (Summer Educational Experience for the Disadvantaged) program at the Oak Ridge National Laboratory.
} 
slope of the linear portion of the test curve. The data was plotted to a power-law equation in order to obtain the creep exponent and activation energy. Optical metallography and scanning electron microscopy (SEM) were used to study the microstructures and fracture modes. Analytical electron microscopy (AEM) using either a Philips CM30 (300 kV) or CM12 [120 kV, with ultra-thin-window x-ray energy dispersive spectrometry (XEDS) detector] electron microscope was performed on samples cut from the gage portion of selected test specimens.

Optical metallography of alloy FA-180 heat treated at $1150^{\circ} \mathrm{C}$ for $1 \mathrm{~h}$ showed the starting microstructure to be composed of $150-250 \mu \mathrm{m}$ diameter grains containing a dispersion of coarse $(\approx 2-4 \mu \mathrm{m}$ diameter) precipitates that were earlier determined to be Mo, $\mathrm{Nb}$, and/or Zr-rich carbides.1,12,13 Larger grains of up to $400 \mu \mathrm{m}$ diameter were also observed in some areas, as was reported earlier for this same alloy and heat treatment.12 AEM of specimens before creep-rupture testing also showed the presence of much finer Zr-rich precipitates within the grains. 12

Tables I and II list the results of creep-rupture tests conducted as a function of test temperature and stress, respectively. The results of tests at temperatures between 593 and $700^{\circ} \mathrm{C}$ showed that under a stress of $207 \mathrm{MPa}$ this alloy had good creep resistance to a temperature of $650^{\circ} \mathrm{C}$, but the creep-rupture life decreased dramatically at $675^{\circ} \mathrm{C}$. Other data in Tables I and II indicate that with a lower stress the use temperature can be pushed to temperatures higher than $650^{\circ} \mathrm{C}$. For example, using a stress of $69 \mathrm{MPa}$, a creep-rupture life of over $500 \mathrm{~h}$ was attained at $675^{\circ} \mathrm{C}$ and almost $200 \mathrm{~h}$ at $700^{\circ} \mathrm{C}$ (Table I). All of the fractured specimens showed a ductile failure mode in which creep voids were observed to have coalesced at grain boundaries and triple points.

Table I. Creep test results for tests conducted at constant stress

\begin{tabular}{cccccc}
\hline \hline Test \# & $\begin{array}{c}\text { Stress } \\
(\mathrm{MPa})\end{array}$ & $\begin{array}{c}\text { Temperature } \\
\left({ }^{\circ} \mathrm{C}\right)\end{array}$ & $\begin{array}{c}\text { Rupture Life } \\
(\mathrm{h})\end{array}$ & $\begin{array}{c}\text { Elongation } \\
(\%)\end{array}$ & $\begin{array}{c}\text { MCRa } \\
(\% / \mathrm{h})\end{array}$ \\
\hline \hline $404 / 405$ & 207 & 700 & 0.6 & 26.2 & 13.6 \\
$407 / 431$ & & 675 & 0.8 & 27.0 & 20.8 \\
410 & & 650 & 1059.0 & 11.0 & 0.002 \\
411 & & 593 & 1959.2 & 9.7 & 0.003 \\
$418 / 420$ & 69 & 775 & 5.1 & 72.6 & 4.0 \\
$417 / 419$ & & 750 & 12.5 & 72.2 & 1.6 \\
$421 / 422$ & & 725 & 54.5 & 52.2 & 0.4 \\
$415 / 416$ & & 700 & 192.1 & 60.4 & 0.03 \\
412 & & 675 & 591.0 & 45.0 & 0.002 \\
\hline \hline
\end{tabular}

aMCR $=$ minimum creep rate measured in the linear portion of the creep curve. 
Table II. Creep test results for tests conducted at constant temperature

\begin{tabular}{cccccc}
\hline \hline Test \# & $\begin{array}{c}\text { Temperature } \\
\left({ }^{\circ} \mathrm{C}\right)\end{array}$ & $\begin{array}{c}\text { Stress } \\
(\mathrm{MPa})\end{array}$ & $\begin{array}{c}\text { Rupture Life } \\
(\mathrm{h})\end{array}$ & $\begin{array}{c}\text { Elongation } \\
(\%)\end{array}$ & $\begin{array}{c}\text { MCRa } \\
(\% / \mathrm{h})\end{array}$ \\
\hline \hline $407 / 431$ & 675 & 207 & 0.8 & 27.0 & 20.8 \\
$425 / 430$ & & 172 & 14.2 & 27.0 & 1.4 \\
$408 / 413 / 414$ & & 138 & 52.2 & 29.0 & 0.1 \\
427 & & 103 & 252.4 & 24.8 & 0.01 \\
412 & & 69 & 591.0 & 45.0 & 0.002 \\
429 & 500 & 379 & 28.2 & & 0.2 \\
426 & & 345 & 54.0 & 25.1 & 0.3 \\
428 & & 310 & 27.9 & & 0.05 \\
\hline \hline
\end{tabular}

$\mathrm{aMCR}=$ minimum creep rate measured in the linear portion of the creep curve.

If one assumes that the mechanisms of dislocation creep in intermetallic alloys do not differ from those in conventional alloys (as has been done by other researchers in the past15-18), then the creep data can be fitted to a power-law creep equation of the form

$$
\dot{\varepsilon}=\mathrm{A} \sigma^{\mathrm{n}}\left(\mathrm{e}^{-\mathrm{Q} / \mathrm{RT}}\right)
$$

where $\dot{\varepsilon}$ is the minimum creep rate (MCR), $A$ is a constant, $\sigma$ is the test stress, $\mathbf{n}$ is the creep exponent, $Q$ is the activation energy for creep, $T$ is the temperature in Kelvin $(K)$ and $R$ is the universal gas constant with a value of $1.987 \mathrm{cal} / \mathrm{mol} /{ }^{\circ} \mathrm{C}$. By rearranging this equation and inserting the data for constant stress or constant temperature tests, the activation energy for creep (Q) and the creep exponent (n) were obtained (see Figs. 1 and 2). The results are accumulated in Table III. The average activation energy was determined to be approximately $150 \mathrm{kcal} / \mathrm{mol}$ which indicates a much stronger temperature dependence of the creep rate for this alloy compared to binary $\mathrm{Fe}-28 \mathrm{Al}$ or the ternary alloys containing additions of only Mo or $\mathrm{Nb} / \mathrm{Zr}(\sim 80 \mathrm{kcal} / \mathrm{mol}) .1,19$ [Note the binary alloy has been shown to have very poor creep resistance under the test conditions used in the current study ${ }^{1}$ and a heat treatment at $1150^{\circ} \mathrm{C}$ produced absolutely no improvement, ${ }^{14}$ as was expected for a binary alloy with no precipitate formers.] A creep exponent of almost 8 suggests that the increased creep strength with the $1150^{\circ} \mathrm{C}$ heat treatment probably involved particle strengthening, $15-17$ and this was substantiated by the AEM results reported earlier.12 Due to the fewer number of tests in this study, any dependence of the creep exponent on the test stress, as was reported earlier for binary and ternary alloys, ${ }^{1}$ was not observed. An investigation of that possibility would need to be part of any further study. 


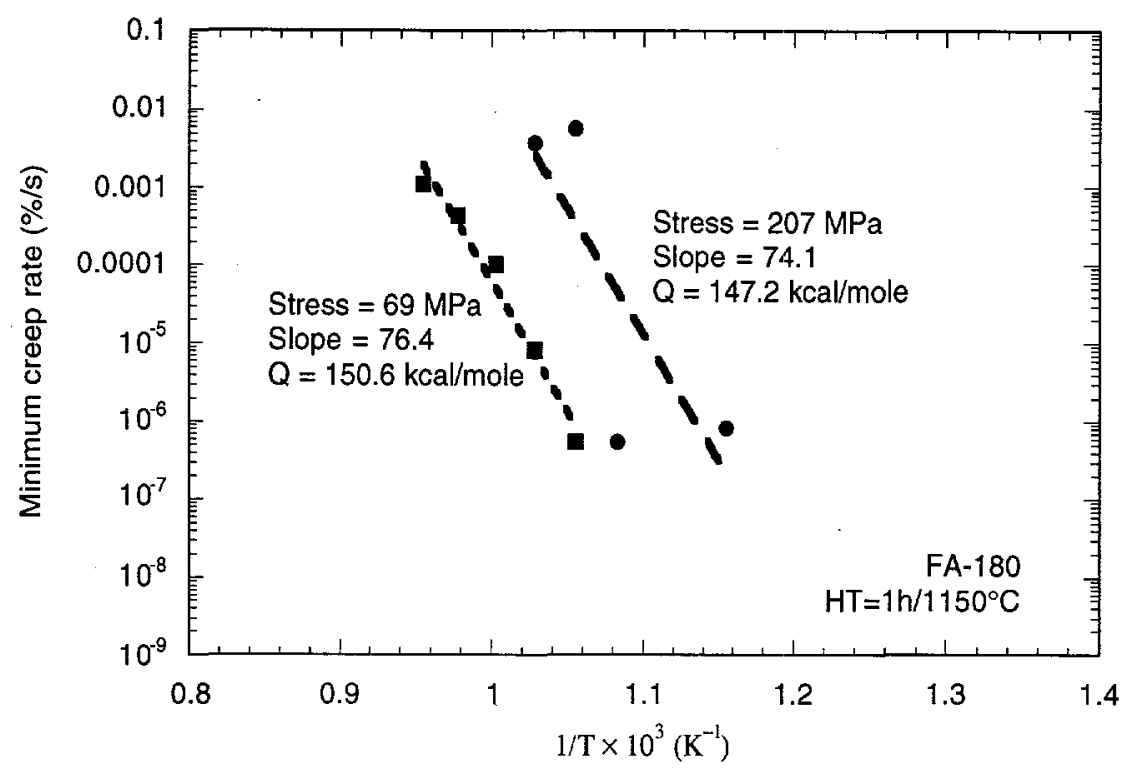

Fig. 1. Minimum creep rate versus temperature for FA-180. The slope represents the activation energy for creep.

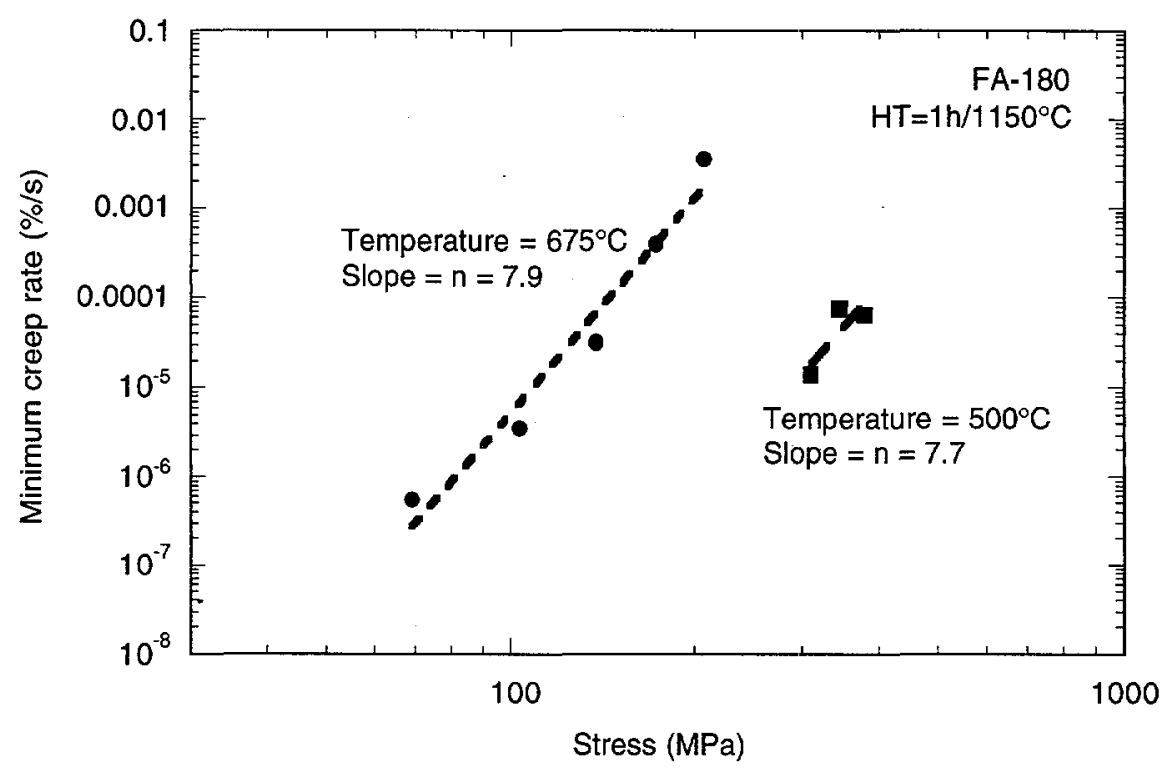

Fig. 2. Minimum creep rate versus stress for FA-180. The slope equals the creep exponent $\mathrm{n}$.

In conclusion, the creep-rupture strength of $\mathrm{Fe}_{3} \mathrm{Al}$-based alloy $\mathrm{FA}-180$ (Fe-28Al-5Cr$0.5 \mathrm{Nb}-0.8 \mathrm{Mo}-0.025 \mathrm{Zr}-0.05 \mathrm{C}-0.005 \mathrm{~B}$, at.\%) has been improved significantly by heat treating for $1 \mathrm{~h}$ at $1150^{\circ} \mathrm{C}$. This strengthening was attributed to the presence of fine matrix and grain boundary $\mathrm{Zr}$-rich MC precipitates. The activation energy for creep in alloy FA-180 was 
determined to be approx. $150 \mathrm{kcal} /$ mole which is twice that determined earlier for binary $\mathrm{Fe}_{3} \mathrm{Al}$. A creep exponent of almost 8 was determined, consistent with a precipitationstrengthening mechanism.

Table III. Activation energies (Q) and creep exponents (n) for alloy FA-180 determined from the results of the present study

\begin{tabular}{cccccc}
\hline \hline Alloy & $\begin{array}{c}\text { Temperature } \\
\left({ }^{\circ} \mathrm{C}\right)\end{array}$ & $\begin{array}{c}\text { Stress } \\
(\mathrm{MPa})\end{array}$ & Slope & $\begin{array}{c}\mathrm{Q} \\
(\mathrm{kcal} / \mathrm{mole})\end{array}$ & $\mathrm{n}$ \\
\hline \hline FA-180 & 675 & $69-206$ & 7.9 & & 7.9 \\
& 500 & $310-380$ & 7.7 & & 7.7 \\
FA-180 & $675-775$ & 69 & 76.4 & 151.8 & \\
& $593-700$ & 207 & 74.1 & 147.2 & \\
\hline \hline
\end{tabular}

\section{REFERENCES}

1. C. G. McKamey, P. J. Maziasz, and J. W. Jones, J. Mater. Res. 7(8), 2089 (1992).

2. C. T. Liu, C. G. McKamey, and E. H. Lee, Scripta Metall. Mater. 24(2), 385 (1990).

3. C. T. Liu and C. G. McKamey, in High Temperature Aluminides and Intermetallics, edited by S. H. Whang, C. T. Liu, D. P. Pope, and J. 0. Stiegler (The Metallurgical Society, Warrendale, PA: 1990), pp. 133-151.

4. P. F. Tortorelli and J. H. DeVan, Mater. Sci. \& Eng. A153, 573 (1992).

5. C. G. McKamey and C. T. Liu, in Proceedings of ADVMAT/91. First International Symposium on Environmental Effects on Advanced Materials, edited by R. D. Kane (NACE, Houston, TX, 1992), paper no. 17-1.

6. V. K. Sikka, SAMPE Quart. 22(4), 2 (1991).

7. V. K. Sikka, S. Viswanathan, and C. G. McKamey, Structural Intermetallics, edited by R. Darolia, J. J. Lewandowski, C. T. Liu, P. L. Martin, D. B. Miracle, and M. V. Nathal (The Metallurgical Society, Warrendale, PA, 1993), pp. 483-91.

8. C. G. McKamey, et al., J. Mater. Res. 6(8), 1779 (1991).

9. P. J. Maziasz and C. G. McKamey, Mater. Sci. \& Eng., A152, 322 (1992).

10. D. M. Dimiduk, et al., Acta Metall. 36, 2947 (1988).

11. D. G. Morris, M. Nazmy, and C. Noseda, Scripta Metall. Mater. 31, 173 (1994).

12. C. G. McKamey and P. J. Maziasz, in Processing. Properties, and Applications of Iron Aluminides, edited by J. H. Schneibel and M. A. Crimp (The Metallurgical Society, Warrendale, PA, 1994), pp. 147-58.

13. C. G. McKamey, et al., Mater. Sci. \& Eng. A174, 59 (1994).

14. C. G. McKamey, unpublished results, 1994.

15. F. Garofalo, Fundamentals of Creep and Creep-Rupture in Metals (The Macmillan Co., New York, 1965).

16. O. D. Sherby and P. M. Burke, Prog. Mater. Sci. 13, 325 (1968).

17. N. S. Stoloff and R. G. Davies, Prog. Mater. Sci. 13, 1 (1966).

18. I. Jung, M. Rudy, and G. Sauthoff, in High Temperature Ordered Intermetallic Alloys II, edited by N. S. Stoloff, C. C. Koch, C. T. Liu, and O. Izumi (Materials Research Society, Pittsburgh, PA, 1987), pp. 263-274.

19. A. Lawley, J. A. Coll, and R. W. Cahn, TMS AIME 218, 166 (1960). 



\title{
2.10 LOW-ALUMINUM CONTENT IRON-ALUMINUM ALLOYS
}

\author{
V. K. Sikka, G. M. Goodwin, D. J. Alexander, and C. R. Howell
}

\section{INTRODUCTION}

The low-aluminum-content iron-aluminum program deals with the development of a $\mathrm{Fe}-\mathrm{Al}$ alloy with aluminum content such as a produce the minimum environmental effect at room temperature. The FAPY is an Fe-16 at. \% Al-based alloy developed at the Oak Ridge National Laboratory as the highest aluminum-containing alloy with essentially no environmental effect. ${ }^{1}$ The chemical composition for FAPY in weight percent is: aluminum $=8.46$, chromium $=5.50$, zirconium $=0.20$, carbon $=0.03$, molybdenum $=2.00$, yttrium $=0.10$, and iron $=83.71$. The cast ingots of the alloy can be hot worked by extrusion, forging, and rolling processes. The hotworked cast structure can be cold worked with intermediate anneals at $800^{\circ} \mathrm{C}$. Typical roomtemperature ductility of the fine-grained wrought structure is 20 to $25 \%$ for this alloy. In contrast to the wrought structure, the cast ductility at room temperature is approximately $1 \%$ with a transition temperature of approximately 100 to $150^{\circ} \mathrm{C}$, above which ductility values exceed $20 \%$. The alloy has been melted and processed into bar, sheet, and foil. The alloy has also been cast into slabs, step-blocks of varying thicknessess, and shapes.

The purpose of this section is to describe the welding response of cast slabs of three different thicknesses of FAPY alloy. Tensile, creep, and Charpy-impact data of the welded plates are also presented.

\section{Discussion of Current Activities}

\section{Casting}

For the welding studies, the FAPY alloy was used in the as-cast condition, prepared by vacuum-induction melting, and cast in graphite molds measuring 100 by $150 \mathrm{~mm}$ (4 by 6 in.) in length and having thicknesses of 12,25 , and $51 \mathrm{~mm}(0.5,1$, and $2 \mathrm{in}$.). All three plates had good as-cast surfaces. The welding studies were conducted on the plates in the as-cast condition. 


\section{Weld Production}

Weld joints were prepared by sawing as shown in Fig. 1. The included angle of $60^{\circ}$ in the double-vee groove geometry was used for all three slab thicknesses and is typical of industrial practice for plate welding.

Weld wire of $3.2 \mathrm{~mm}$ ( $0.125 \mathrm{in}$.) diam with a matching composition of FAPY alloy was used for all weldments using the manual gas tungsten arc (GTA) process. The joint surfaces and filler wire were cleaned by wire brushing and solvent degreasing with acetone. A summary of the welding parameters is shown in Table 1.

Preheat, when used, was accomplished with an oxyacetylene torch. Interpass temperature was maintained at $350^{\circ} \mathrm{C}$ minimum. Postweld heat treatment (PWHT), when used, was done immediately following welding in an air furnace followed by free cooling in still air.

Completed weldments were examined for possible defects using liquid-dye penetrant. A summary of the inspection results is shown in Table 2. End sections were removed from each weldment for optical metallography.

\section{Mechanical Properties}

The welded slabs were cut up for mechanical property determinations. The 12-mm (0.5-in.) -thick plates were used for Charpy-impact testing. The 25- and 51-mm (1- and 2-in.) -thick plates were used for tensile and creep properties. The specimen cut-up diagrams for the Charpy, tensile, and creep specimens are shown in Fig. 2.

\section{Tensile Properties}

The tensile data from room temperature to $800^{\circ} \mathrm{C}$ for the 25 - and $51-\mathrm{mm}$ (1- and 2-in.) -thick welded plates are summarized in Table 3 . The strength and ductility data of the weldments are plotted and compared with the base-metal data of the cast slabs in Figs. 3 through 6 . The following observations are possible from these figures:

1. The $0.2 \%$ yield strength of the weldment specimens is essentially the same as the base-metal values for the entire temperature range. This is true for specimens taken from both the 25and 51-mm (1- and 2-in.) -thick welded plates.

2. The ultimate tensile strength of the weldment specimens from the 51-mm (2-in.) -thick plate showed lower values than the base metal in the test-temperature range up to $200^{\circ} \mathrm{C}$. This is the same temperature region where ductility of both base metal and weldments is low (see Figs. 5 and 6). The observed results in Fig. 4 imply that the weldment specimens from the 


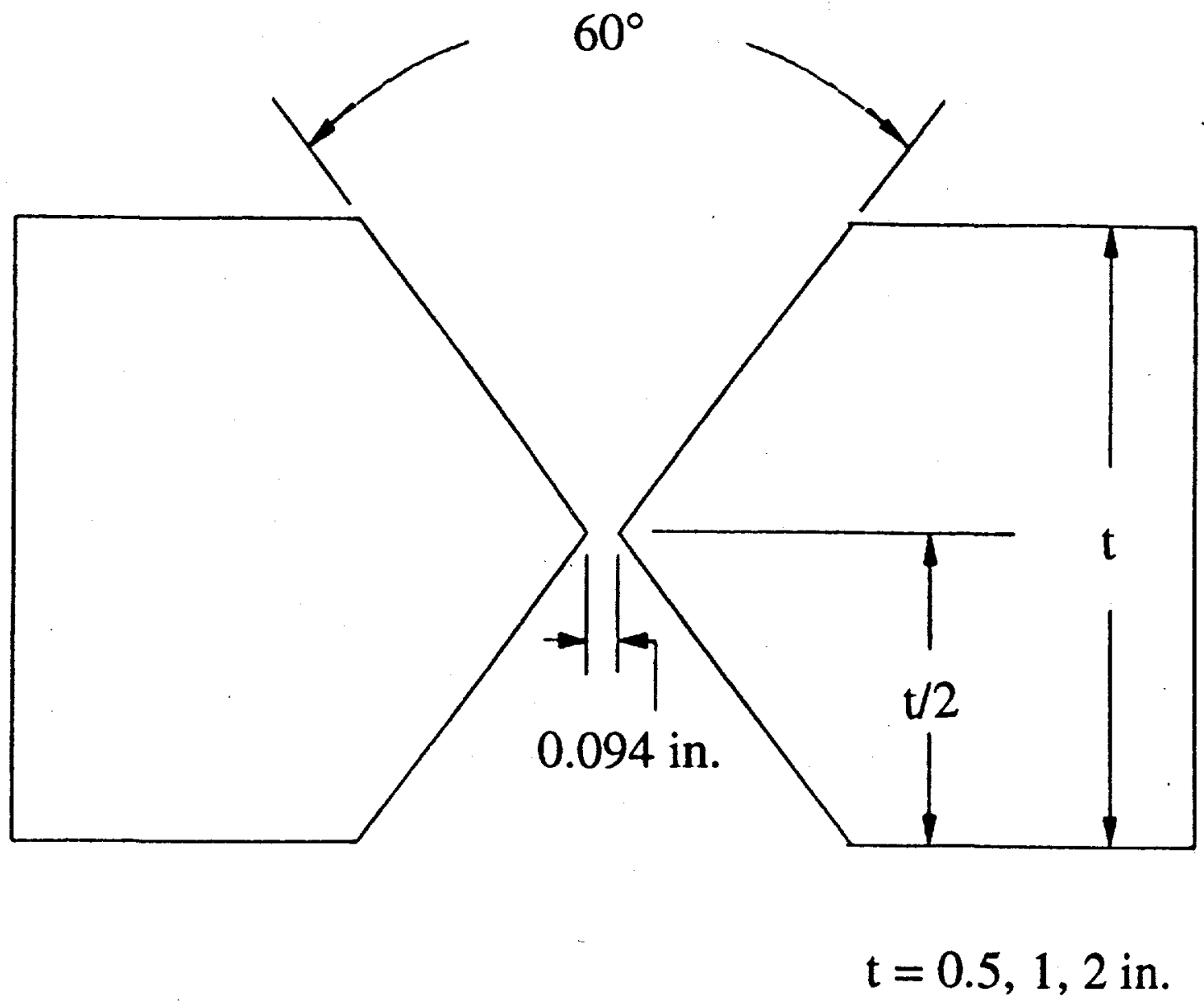

Fig. 1. Joint geometty for FAPY cast slab welds.

51-mm (2-in.) -thick plates are slightly more brittle in this temperature range than base metal or 25-mm (1-in.) -thick plate.

3. The general trend of total elongation and reduction of area of weldments is the same as that for the base metal (see Figs. 5 and 6).

\section{Creep Properties}

The creep data on three weldment specimens machined from 25-mm (1-in.) -thick welded plate are summarized in Table 4 . The creep-rupture data on the weldment specimens are compared with the previously developed data on as-cast and wrought base-metal specimens in Fig. 7 which shows that although limited in number, the short-term data on weldment specimens match the data on base-metal, as-cast, and wrought specimens. It should be recognized that longterm data are required to further confirm these observations. 
Table 1. Welding parameters for cast FAPY alloy slabs

Process:

Joint geometry:

Base metal:

Filler metal:

Weld current:

Weld voltage:

Torch gas:

Backing gas:

Approximate number of passes (alternating sides):

10 to $12 \mathrm{~V}$
Manual gas tungsten arc

Double-vee groove, $60^{\circ}$ included angle

Cast slabs [100¥150¥12,15, and $51 \mathrm{~mm}(4 \times 6 \times 0.5,1$, and

2 in.) thicknesses]

3.2-mm (0.125 in.) -diam rod, matching composition

100 to 175 A direct current electrode negative

Argon, $15 \mathrm{cfh}(7.1 \mathrm{~L} / \mathrm{min})$

Argon, $15 \mathrm{cfh}(7.1 \mathrm{~L} / \mathrm{min})$

12-mm (0.5-in.) slab: 6

25-mm (1-in.) slab: 25

51-mm (2-in.) slab: 65

Table 2. Inspection results of cast FAPY alloy slab welds

\begin{tabular}{|c|c|c|c|c|}
\hline \multicolumn{2}{|c|}{ Temperature, ${ }^{\circ} \mathrm{C}$} & \multicolumn{3}{|c|}{ Slab thickness, mm (in.) } \\
\hline Preheat & Postheat & $12(0.5)$ & $25(1)$ & $51(2)$ \\
\hline 350 & 750 & No cracks & No cracks & No cracks \\
\hline 200 & 750 & -- & -- & No cracks \\
\hline 20 & 20 & No cracks & Cracks & -- \\
\hline
\end{tabular}

\section{Charpy-Impact Tests}

Full-size Charpy-impact specimens were machined from two welded plates of $12 \mathrm{~mm}$ (0.5 in.) thickness. One of the plates contained a weld in the as-welded condition, and the other one was given a PWHT at $750^{\circ} \mathrm{C}$ for $1 \mathrm{~h}$. The schematic in Fig. 2 shows the cut-up schedule for the Charpy specimens. The crack growth was parallel to the welding direction (T-L orientation). The specimens were tested on a 325-J capacity impact tester, and the data are summarized in Table 5. The data, plotted in Fig. 8, were fitted with a hyperbolic tangent function. The lowershelf energy was fixed at $2 \mathrm{~J}$ and the upper-shelf energy was fixed at the value of the test at $400^{\circ} \mathrm{C}$ for each set of specimens (122 J for the as-welded specimens, $144 \mathrm{~J}$ for the postweld heat-treated specimens). 

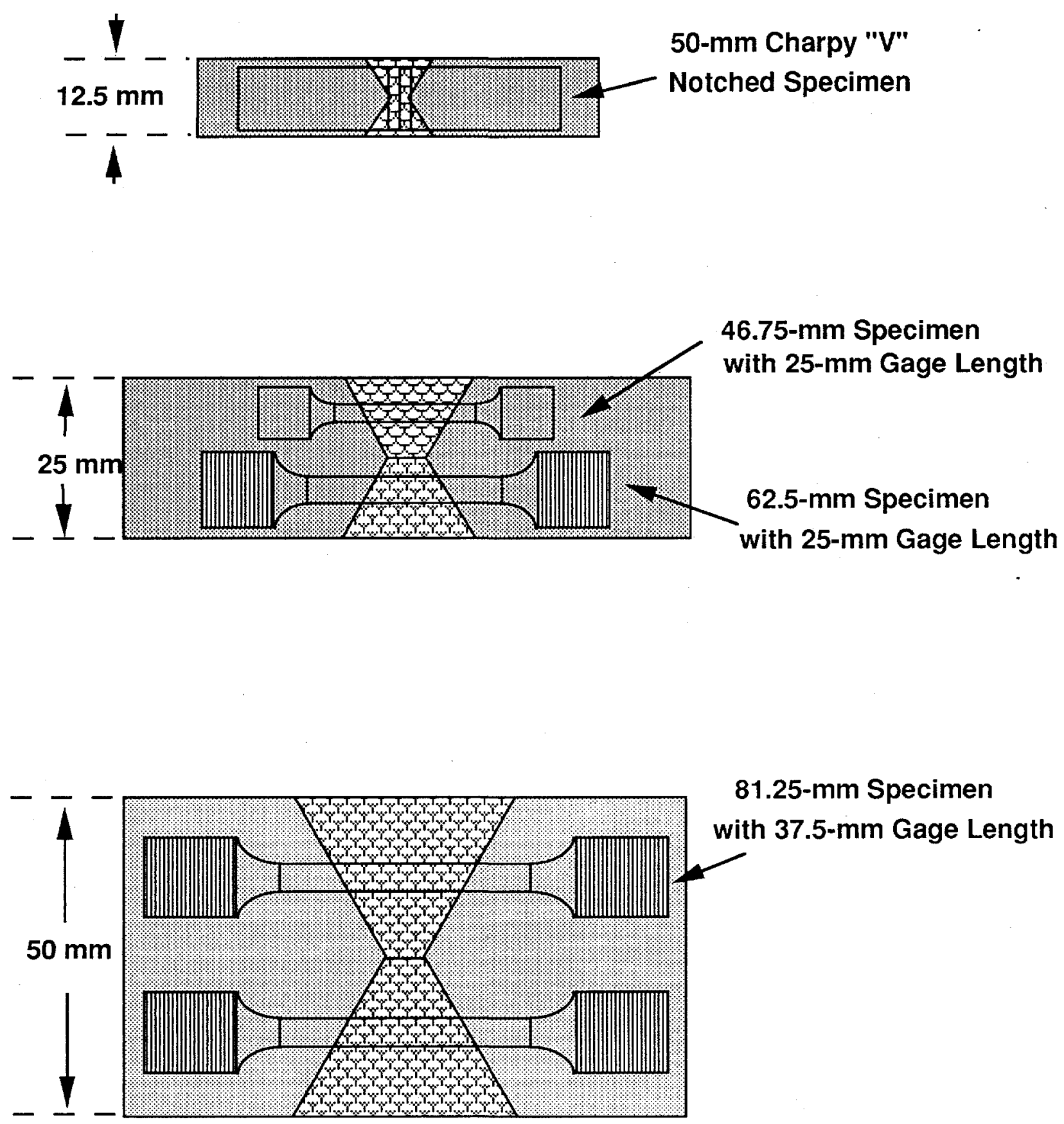

81.25-mm Specimen with 37.5-mm Gage Length

Fig. 2 Schematic showing the location and size of mechanical property specimens machined from welded slabs of FAPY alloy.

The results show that the PWHT does improve the toughness of the material. The ductile-to-brittle transition temperature, defined at an energy level midway between the upperand lower-shelf energy levels, decreases from $245^{\circ} \mathrm{C}$ for the as-welded material to $200^{\circ} \mathrm{C}$ for the material that was given the postweld heat treatment, a $45^{\circ} \mathrm{C}$ improvement. The transition 


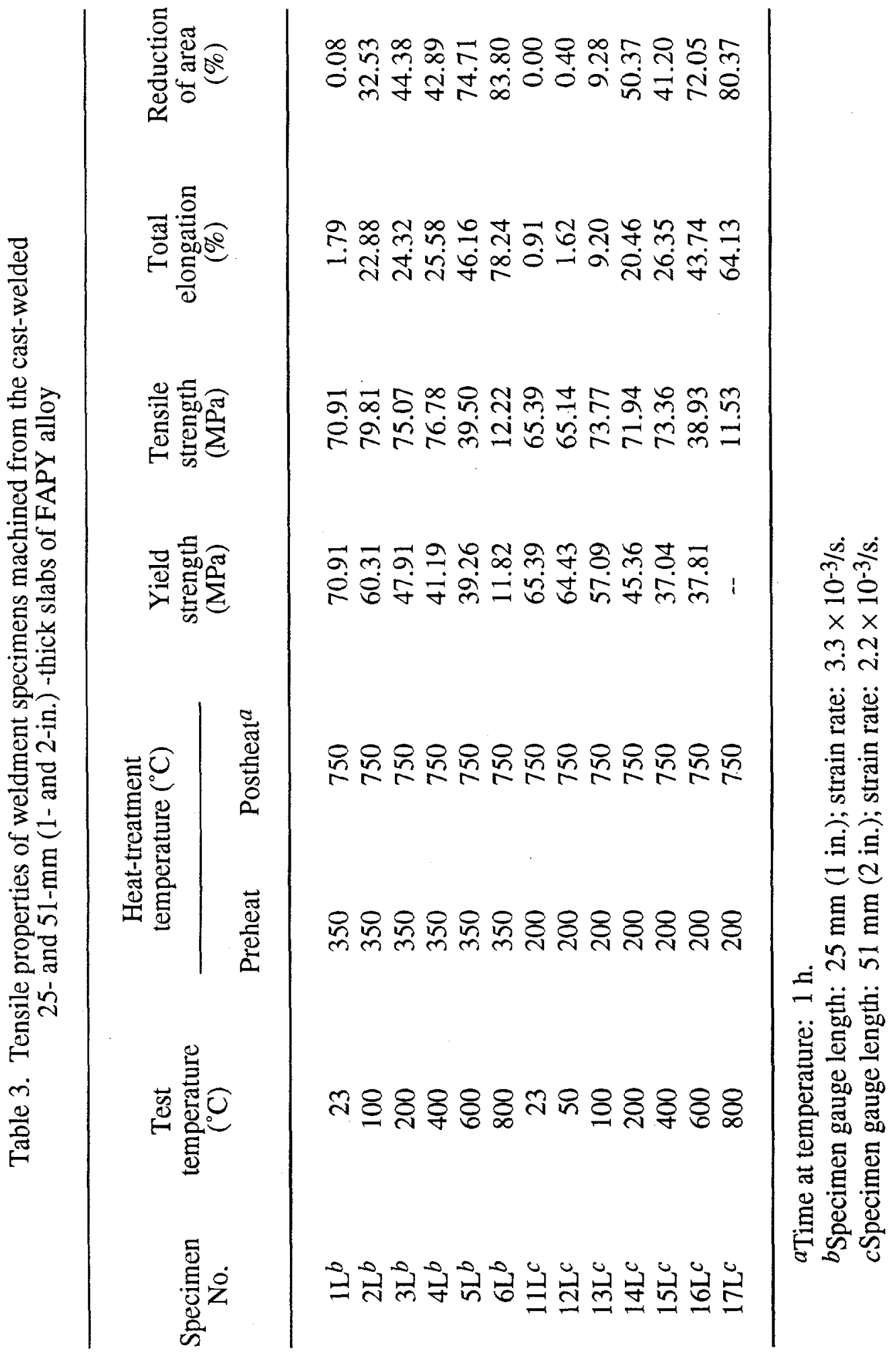




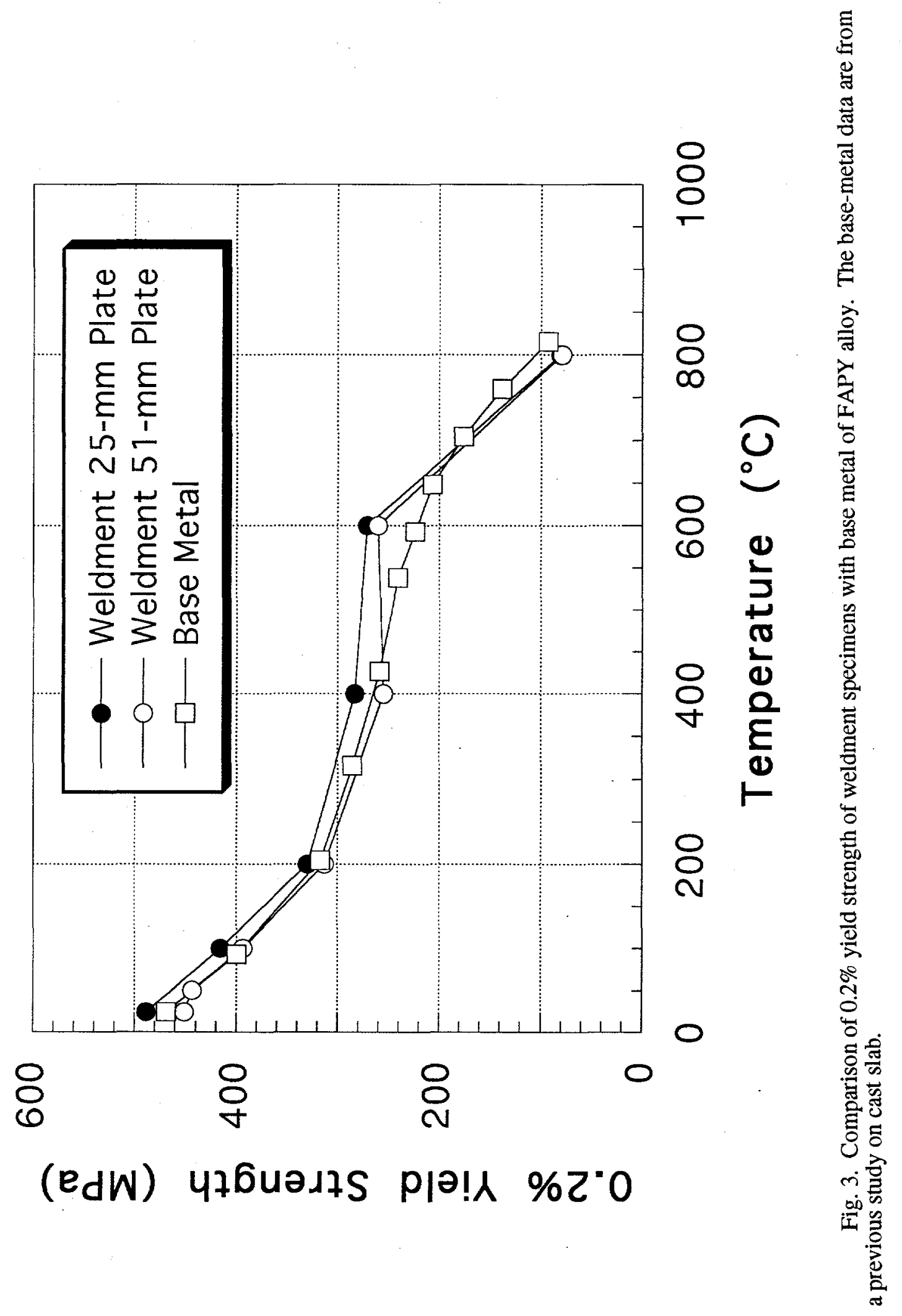




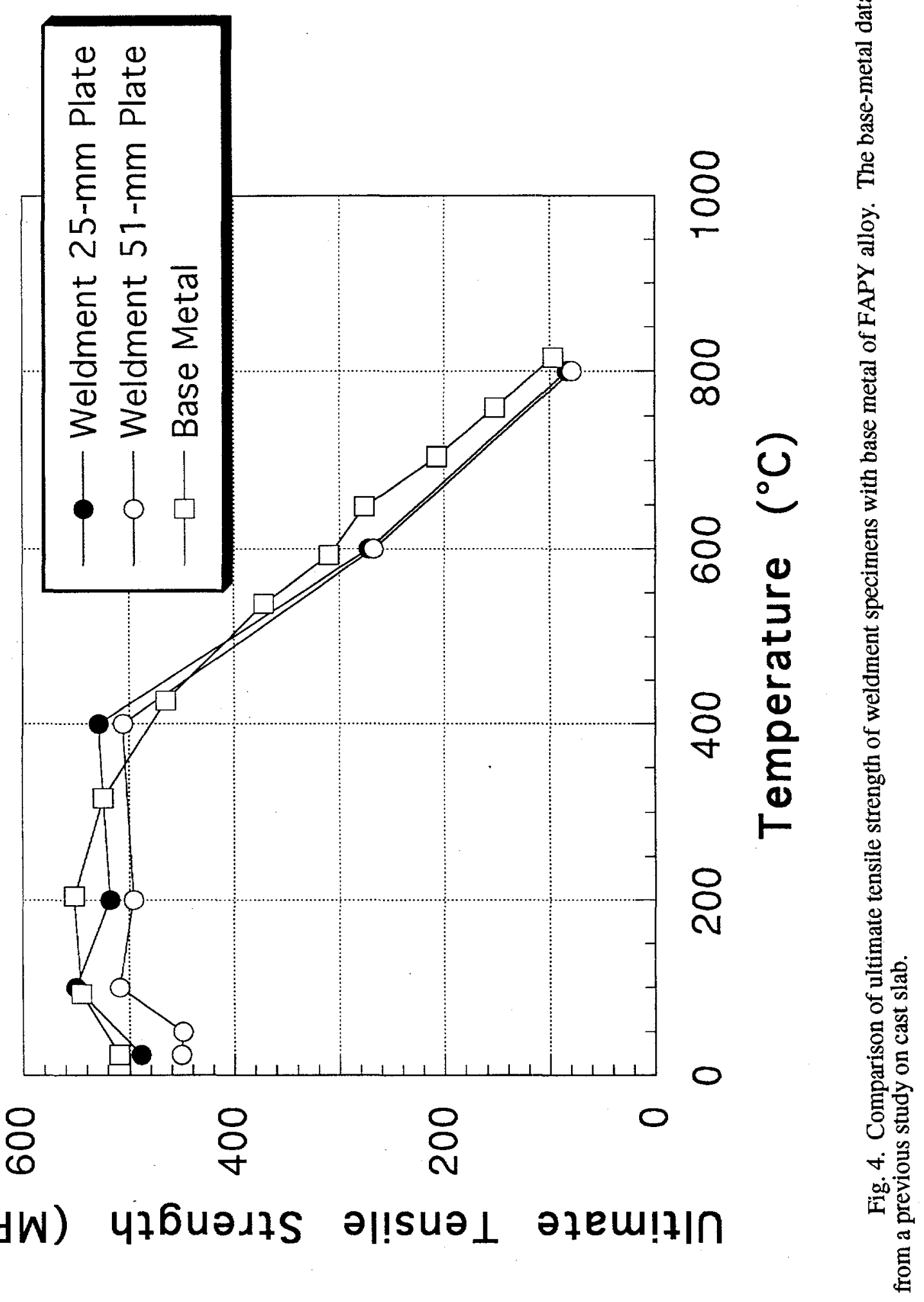




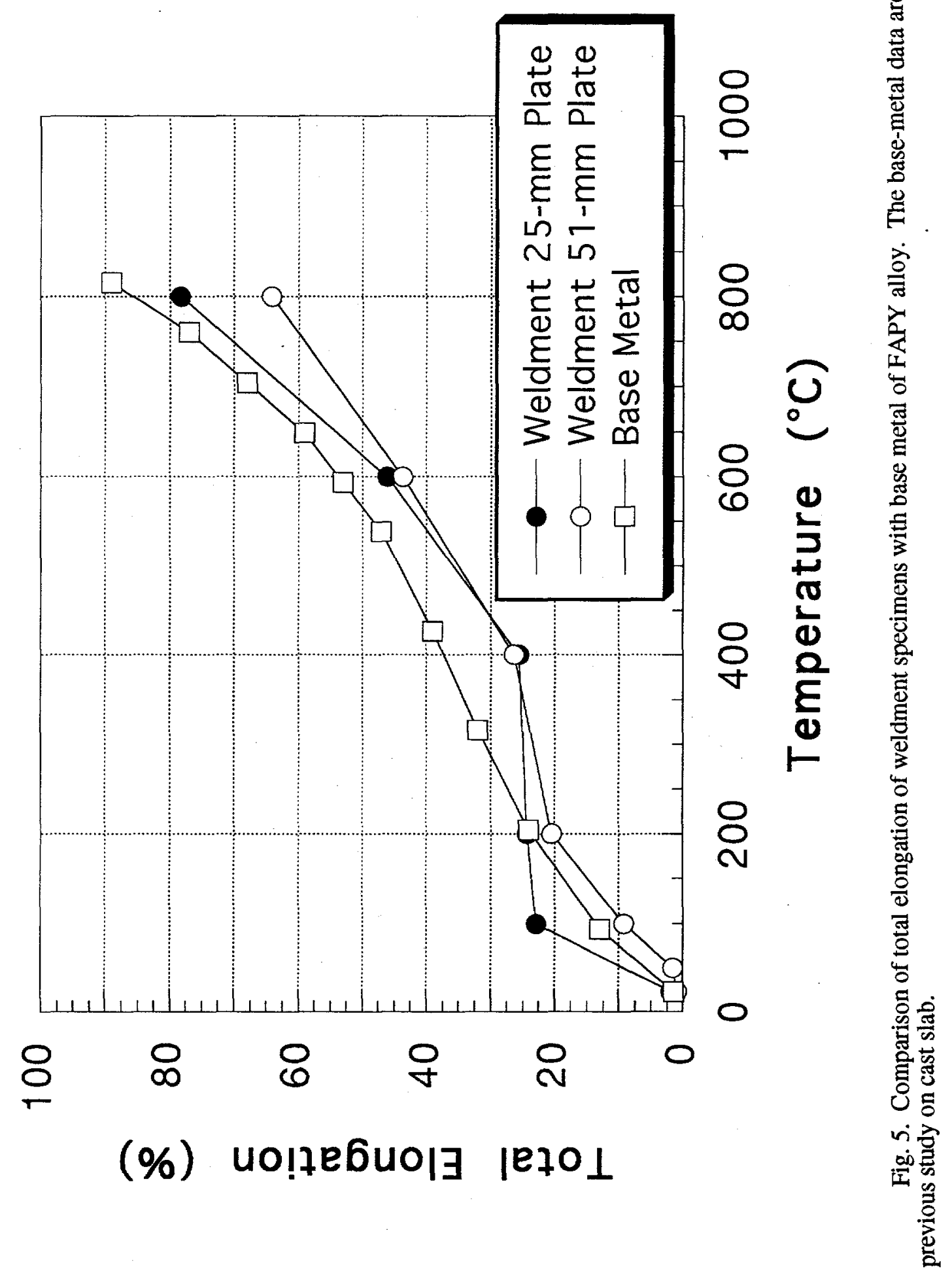




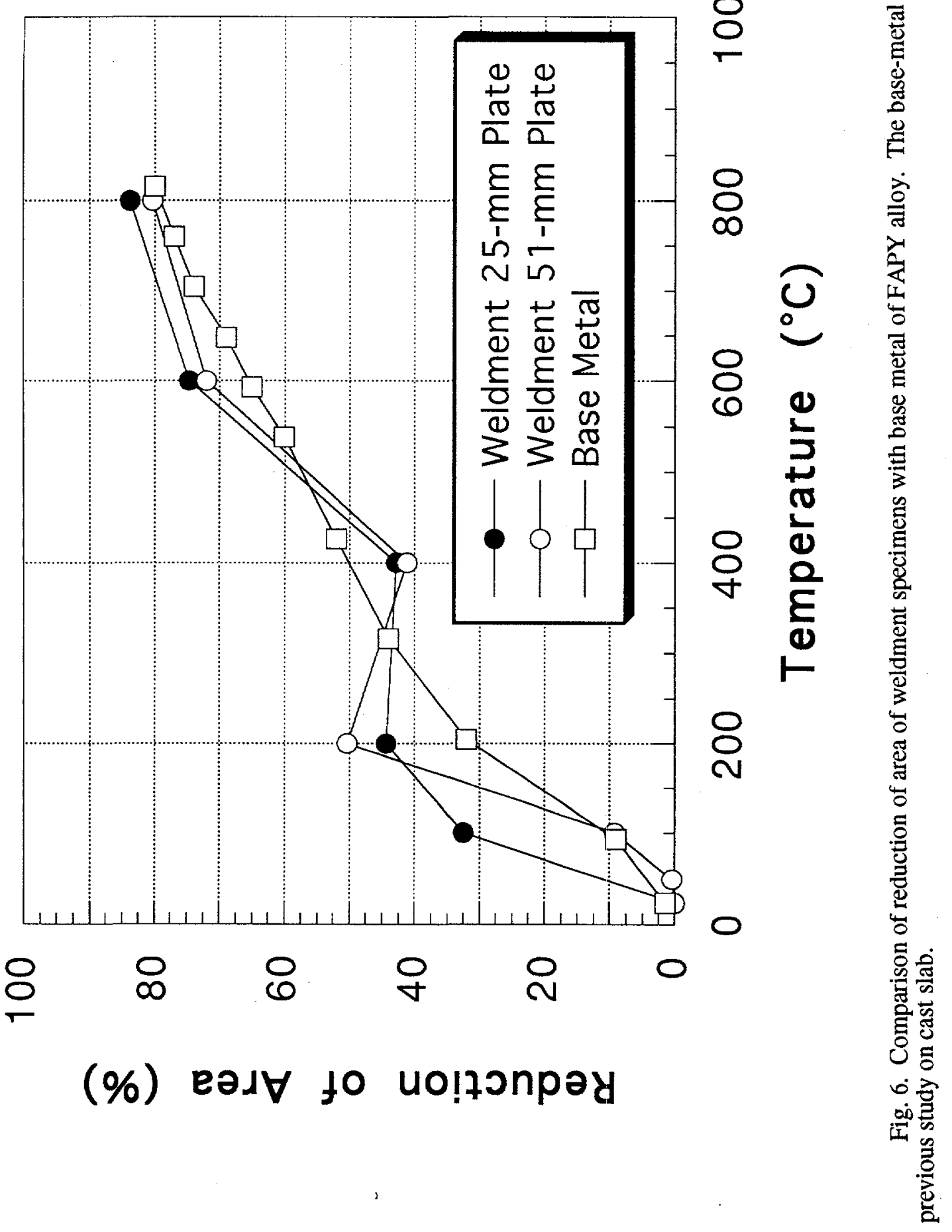




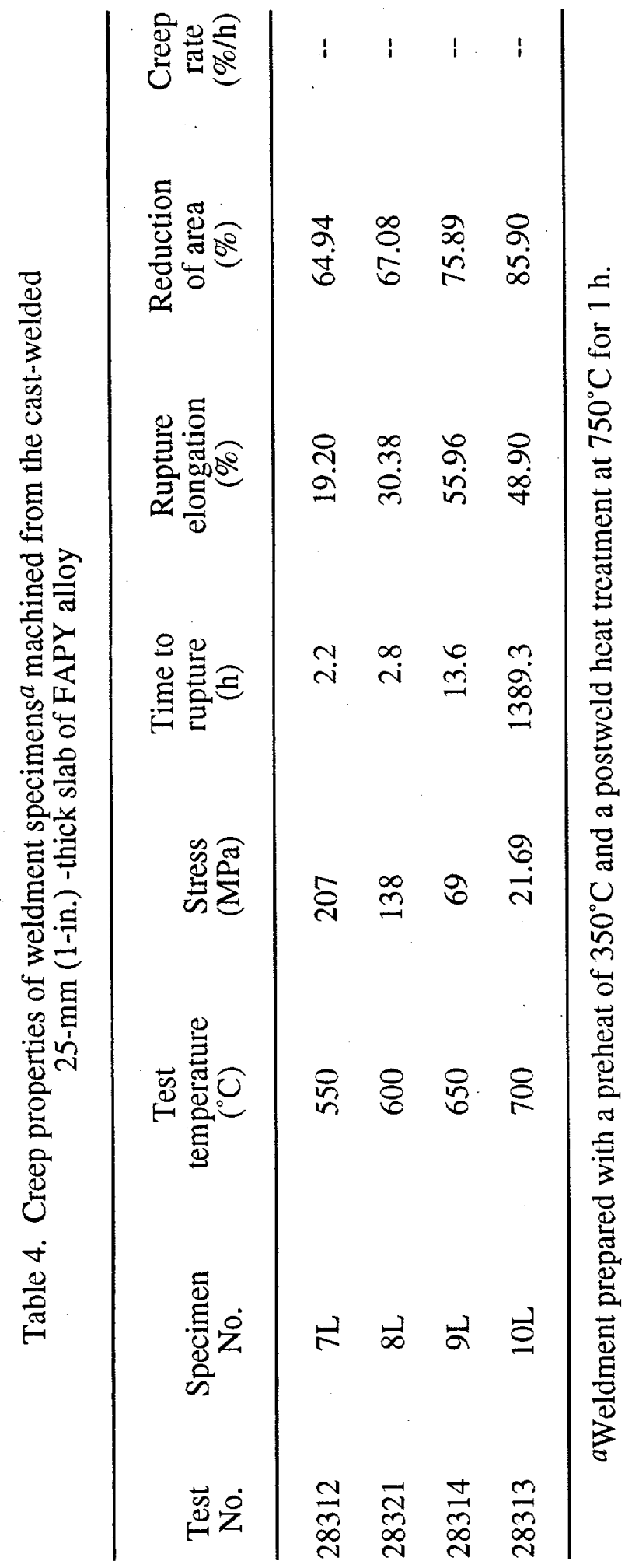



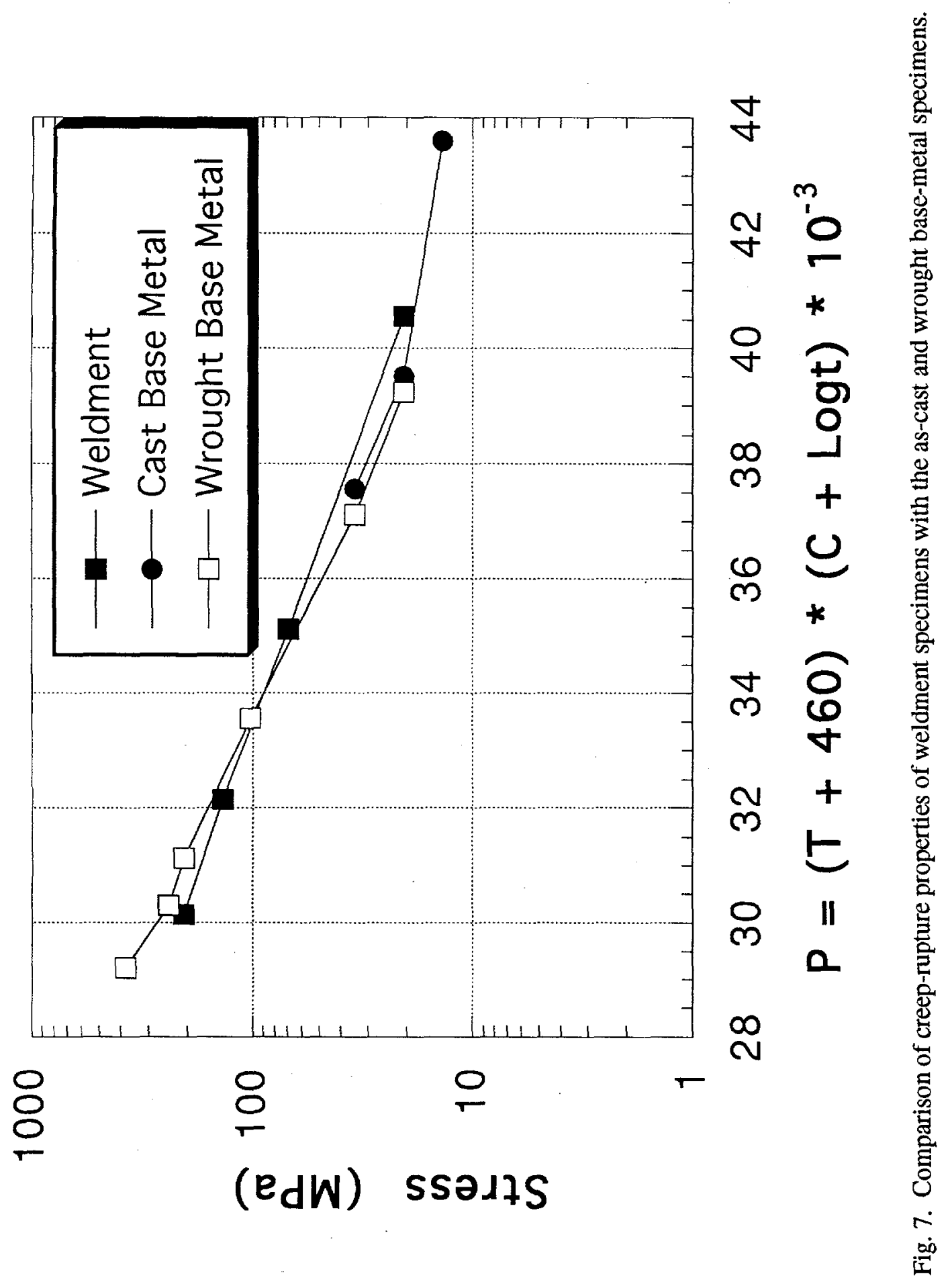


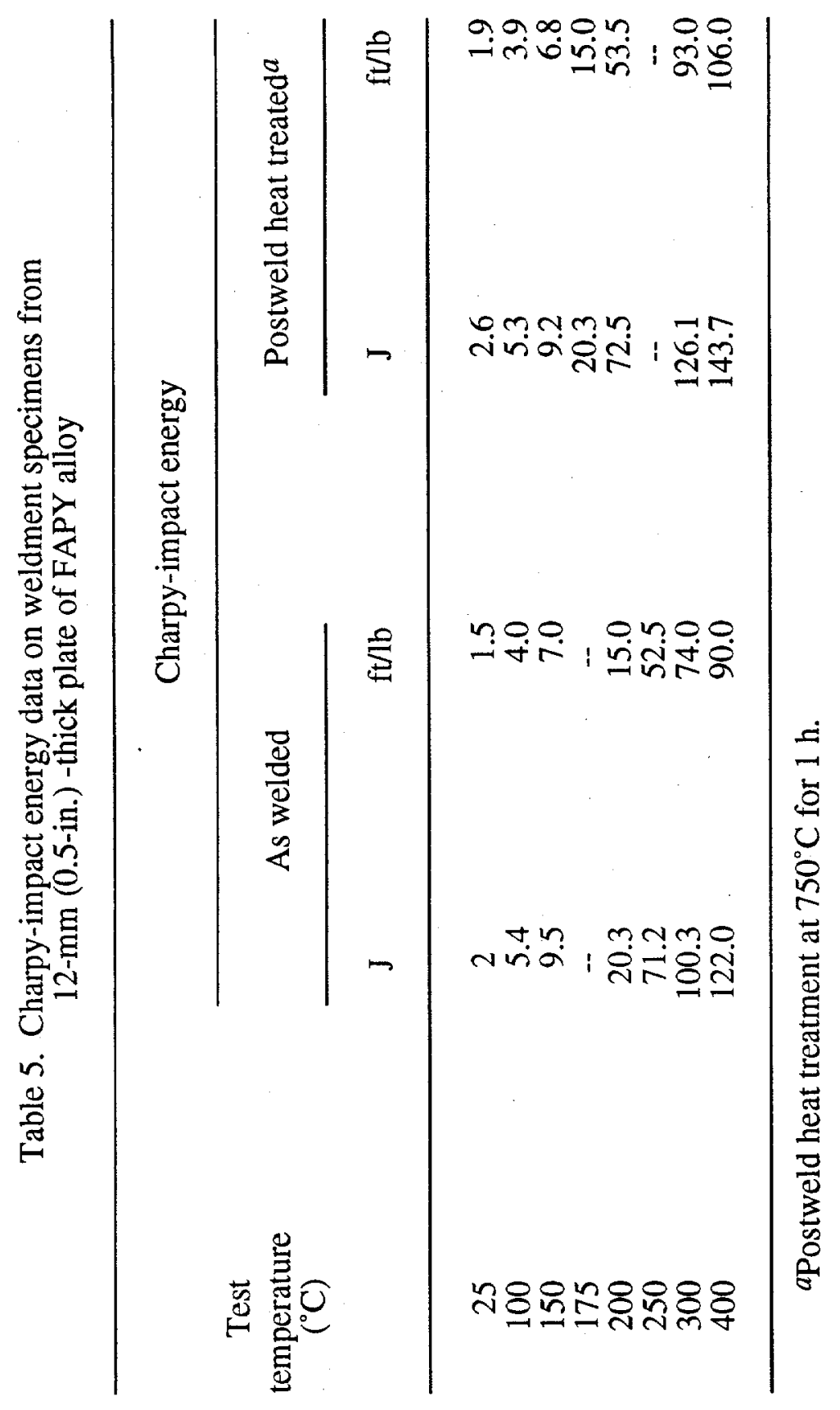




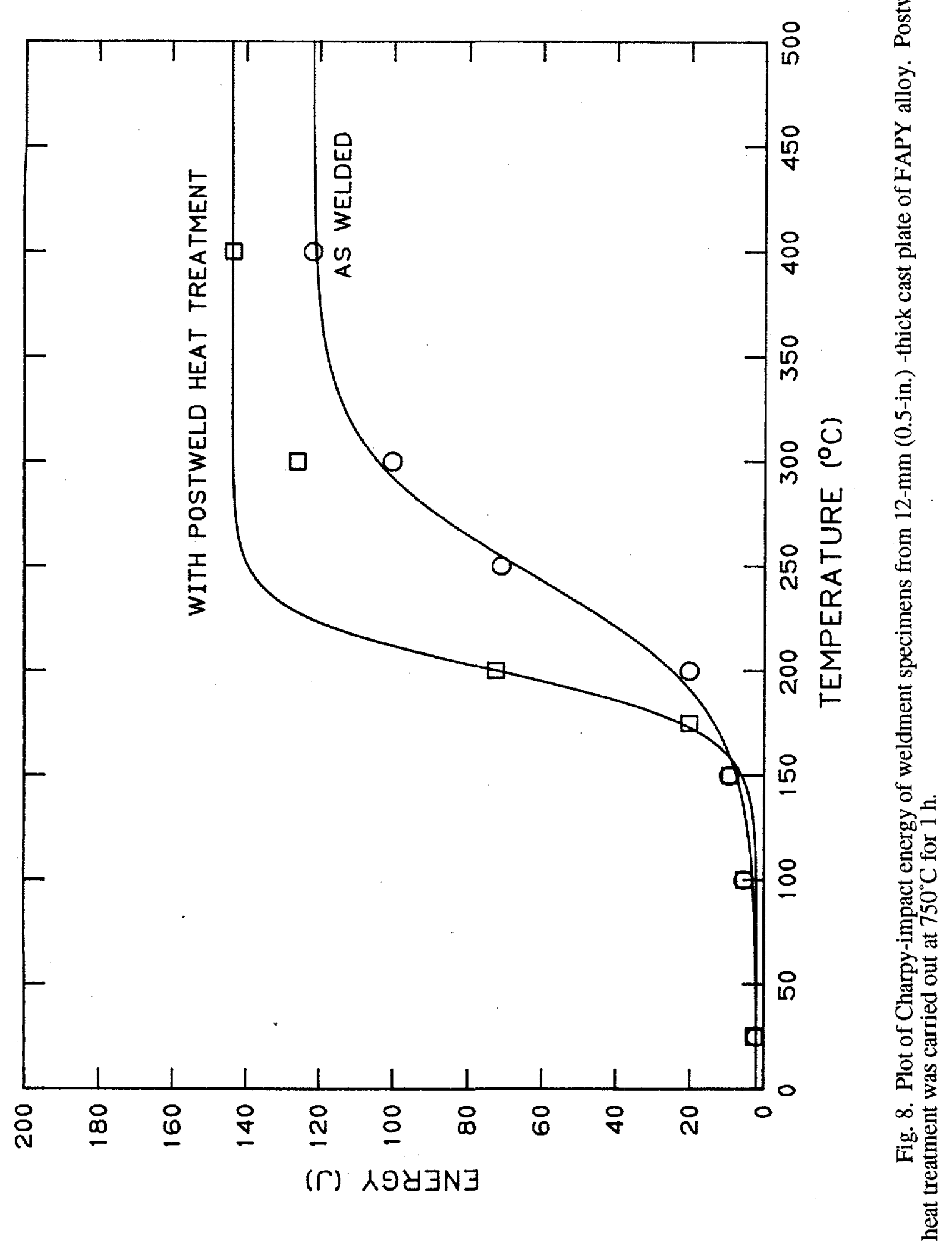


temperature is still quite high however. The upper-shelf energy also improves with heat treatment, increasing from 122 to $144 \mathrm{~J}$. The specimens tested at $400^{\circ} \mathrm{C}$ showed completely ductile fracture, and they provide a good estimate of the upper-shelf energy, although only one specimen was tested for each material at high enough temperatures to give fully ductile fracture.

The Charpy-impact energy data for the weldment specimens are compared with that of the wrought base-metal data in Fig. 9. This figure shows that the transition temperature is approximately $50^{\circ}$ higher for the weldment specimens, and the upper-shelf energy is lower by approximately $100 \mathrm{~J}$. The most likely cause for the higher transition temperature for the weldment specimens is their much coarser grain size as opposed to the wrought material.

\section{Microstructure and Hardness Data}

In addition to the macroetched cross sections, photomicrographs of various regions of the weldment were also taken. The general observations from the weldment photomicrographs are: (1) the weld metal showed a coarse-grained structure similar to the cast base metal, and (2) the region identified as HAZ had an epitaxial grain growth of the base-metal grains into the weld metal.

The microhardness data of the base-metal, HAZ, and weld-metal regions show that they are essentially the same for plates of a given thickness (see Table 6). However, there is approximately a 10- to 20-dph point increase in hardness of thicker plates as opposed to a 12 -mm (0.5-in.) -thick plate.

\section{DISCUSSION}

The vacuum-induction-melted and as-cast plates of 12,25 , and $51 \mathrm{~mm}(0.5,1,2 \mathrm{in}$.) thicknesses were successfully welded using the GTA process. All of the welds used a filler wire of base-metal composition. The 12-mm (0.5-in.) -thick plate could be welded without a preheat. However, $25 \mathrm{~mm}$ ( $1 \mathrm{in}$.) and thicker sections required a preheat to make crack-free welds. The preheat temperature for the FAPY alloy can be as low as $200^{\circ} \mathrm{C}$, which is no different than that required for most of the ferritic steels. In addition to preheat, a PWHT of $750^{\circ} \mathrm{C}$ is highly desirable for lowering the transition temperature and increasing the upper-shelf energy during Charpy-impact testing.

The microstructure of the starting plates was coarse due to being in the as-cast condition. For the thinner plate of $12 \mathrm{~mm}(0.5 \mathrm{in}$.) thickness, the grain structure was primarily columnar. However, for the plates of 25 and $51 \mathrm{~mm}$ ( 1 and $2 \mathrm{in}$.) thicknesses, some equiaxed structure was also present in addition to the columnar structure. The weld region also showed a coarse-grained 

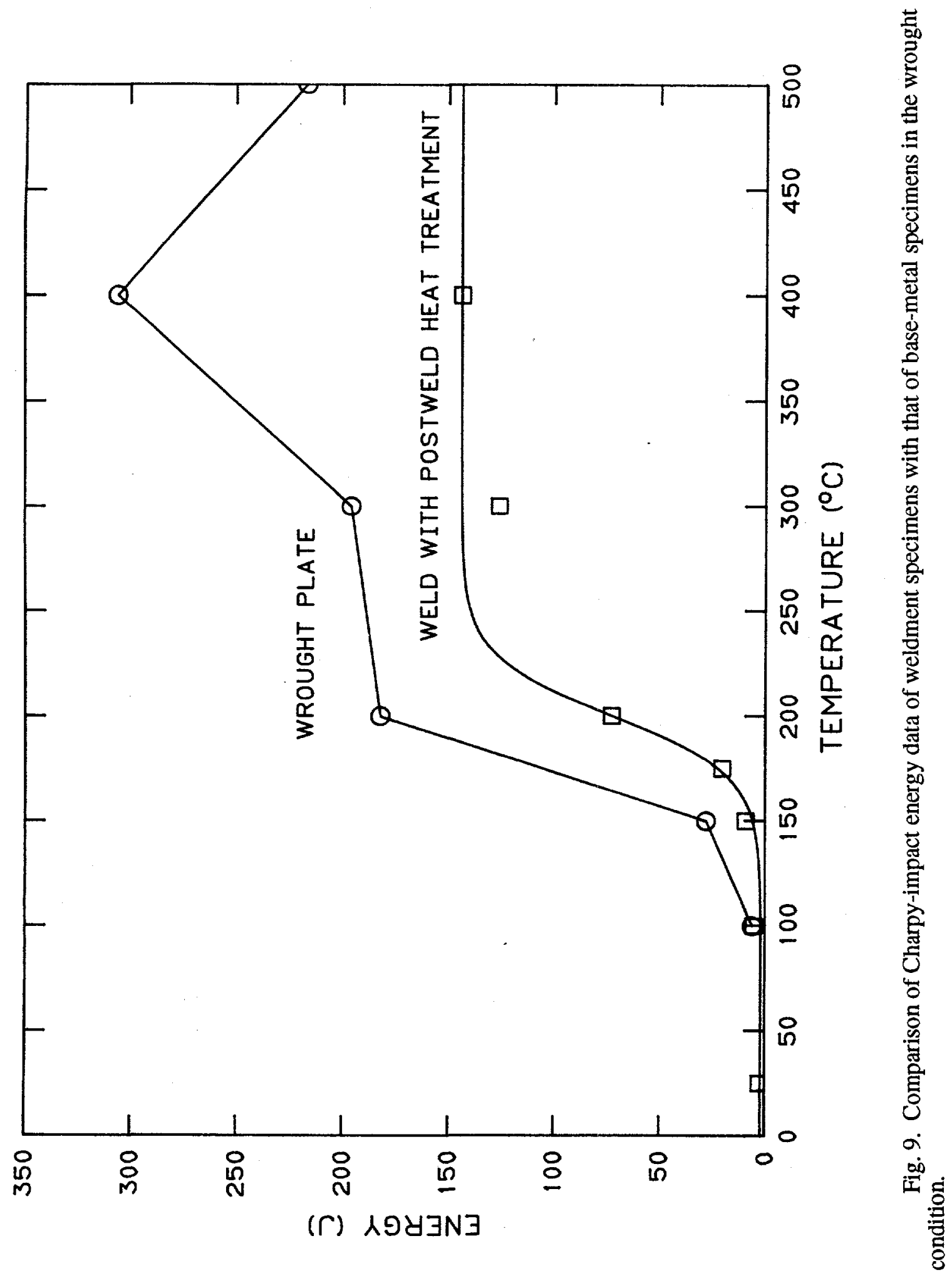


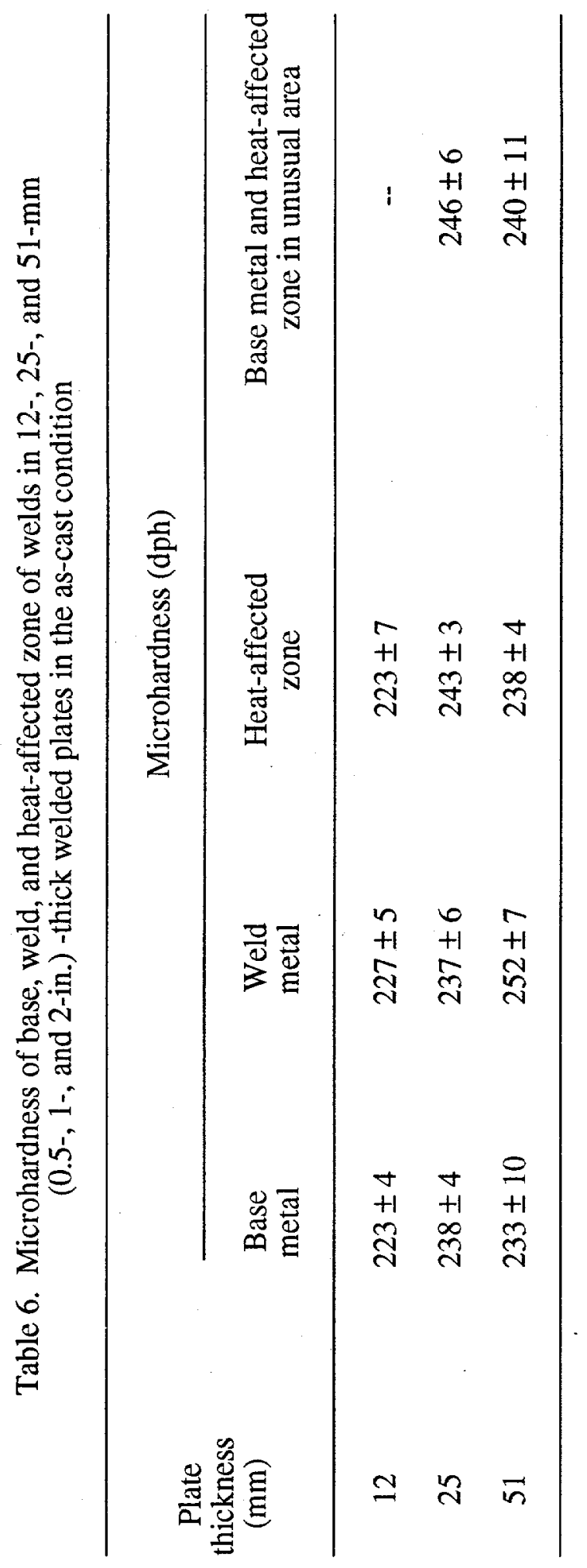


microstructure similar to the cast structure of the base metal. Indications of epitaxial growth of base-metal grains into the weld region were observed. No distinct transition in microstructure was observed from the base- to the weld-metal regions. This observation was confirmed by noting essentially the same microhardness values for base-metal, HAZ, and the weld-metal region. The uniformity in microstructure and microhardness was also confirmed by the failure of the tensile specimens in the middle of the gage section, which normally happens for a material of uniform properties.

The similarity in microstructure and microhardness of the base and weld metals yielded tensile properties of the weldment specimens to match the base-metal properties. A similar match was also observed for the creep-rupture properties. It is important to note that although the properties of the weldment specimens matched the base-metal properties in the as-cast condition, the ductility values for FAPY alloy are too low at temperatures $\leq 100^{\circ} \mathrm{C}$.

An unusual event of cracking was observed in this weldment section of the $51-\mathrm{mm}$ (2-in.) -thick plate during the etching process to reveal its macrostructure. The acid-etching process is known to produce hydrogen, and it is this hydrogen that is believed to have caused the cracking. This cracking was observed only in the 51-mm (2-in.) -thick plate and not in the plates of 12 and $25 \mathrm{~mm}(0.5$ and $1 \mathrm{in}$.) thicknesses. Since the hydrogen-related cracking typically requires the combination of stress and the presence of hydrogen, it is believed that a PWHT of $750^{\circ} \mathrm{C}$ was not adequate to relieve the welding stresses for the 51-mm (2-in.) -thick plate. However, the same PWHT must have been adequate for the thinner sections, which had lower welding stresses to start with because of their thinner sections. Thus, it is believed that a higher PWHT temperature than $750^{\circ} \mathrm{C}$ may be required for section sizes of $\geq 51 \mathrm{~mm}$ ( 2 in.). Additional work is required to establish the PWHT requirements as a function of section thickness for the FAPY alloy.

\section{SUMMARY AND CONCLUSIONS}

The as-cast plates of 12,25 , and $51 \mathrm{~mm}(0.5,1$, and $2 \mathrm{in}$.) thicknesses of FAPY alloy were welded using the GTA process and a $3-\mathrm{mm}(0.125-\mathrm{in}$.) -diam filler wire of matching composition. Welds were made without any preheat and with preheats of 200 and $300^{\circ} \mathrm{C}$. The crack-free welds could be prepared in 12-mm (0.5-in.) -thick plates. However, the thicker plates required a preheat for crack-free welds, and a temperature of $200^{\circ} \mathrm{C}$ was acceptable up to plate thickness of $51 \mathrm{~mm}$ ( $2 \mathrm{in}$.). The preheat temperature for thicker sections may be higher and needs to be determined. The PWHT at $750^{\circ} \mathrm{C}$ for $1 \mathrm{~h}$ was found to lower the transition temperature and increase the upper-shelf energy during Charpy-impact testing of the 12-mm (0.5-in.) -thick welded plate. Thus, all the other weldment properties were determined in the postweld heattreated condition. Tensile and creep properties of the weldment specimens matched the 
properties of the base metal. These results were explained on the basis that the microstructure and microhardness of the weld region were similar to the base metal.

Major conclusions from this study include:

1. The cast plates of the FAPY alloy can be welded by a commonly used GTA process. A filler wire of composition matching the base metal is acceptable. No preheat is required for plates of $12 \mathrm{~mm}(0.5 \mathrm{in}$.) thickness. Plates of $\geq 25 \mathrm{~mm}$ ( $1 \mathrm{in}$.) thickness require a preheat of at least $200^{\circ} \mathrm{C}$. A PWHT at $750^{\circ} \mathrm{C}$ for $1 \mathrm{~h}$ is desirable to improve the Charpy-impact properties and to reduce the suceptibility of the weld to hydrogen-related cracking. A PWHT temperature of higher than $750^{\circ} \mathrm{C}$ is probably required to eliminate the hydrogen-related cracking in the 51mm (2-in.) -thick welds. However, a correlation of PWHT as a function of section thickness needs to be developed.

2. Tensile and creep properties of the weldment specimens matched that of the base metal. These results are explained on the basis that the microhardness and microstructure of the welds are very similar to the base metal.

\section{FUTURE WORK}

Additional work is required on welding of thicker sections of the FAPY alloy:

1. Prepare welds in a section thickness greater than $51 \mathrm{~mm}(2 \mathrm{in}$.$) , and determine the PWHT$ temperatures to eliminate hydrogen-related cracking. Macroetching solution can be used to determine the presence of hydrogen-related cracking.

2. Determine the effect of PWHT temperature on Charpy-impact properties. Use these data to select the optimum temperature for the best combination of transition temperature and uppershelf energy.

3. Determine additional weldment creep tests to obtain data for rupture times exceeding $1000 \mathrm{~h}$.

\section{REFERENCES}

1. S. Vyas, S. Viswanathan, and V. K. Sikka, "Effect of Aluminum Content on Environmental Embrittlement in Binary Iron-Aluminum Alloys," Scr. Metall. Mater. 27, 185-190 (1992). 



\title{
2.11 HIGH-TEMPERATURE CORROSION BEHAVIOR OF IRON ALUMINIDE ALLOYS AND COATINGS
}

\author{
P. F. Tortorelli, J. H. DeVan, B. A. Pint,,and I. G. Wright \\ Oak Ridge National Laboratory \\ Oak Ridge, Tennessee, U. S. A. \\ and
}

\author{
S. R. J. Saunders \\ National Physical Laboratory \\ Teddington, Middlesex, United Kingdom
}

\section{INTRODUCTION}

The iron-aluminum system has been studied by alloy developers for over sixty years. ${ }^{1}$ A primary reason is the potential of iron aluminides for excellent high-temperature corrosion resistance in a number of environments. Alumina surface layers will form on iron aluminides

even in environments with extremely low oxygen partial pressures. ${ }^{2}$ This ability to form $\mathrm{Al}_{2} \mathrm{O}_{3}$ across a wide range of oxygen activities allows iron aluminides to be corrosion resistant not only in air or oxygen, but also to a variety of mixed gases and salts. ${ }^{3}$ Therefore, determining the corrosion behavior of $\mathrm{Fe}_{3} \mathrm{Al}$ alloys in aggressive environments at elevated temperatures forms an important part of the development of these aluminides. This paper reports recent results on the high-temperature corrosion behavior of iron aluminides relevant to three areas of alloy and process development for fossil-energy applications: oxidation of selected oxide-dispersion-strengthened (ODS) $\mathrm{Fe}_{3} \mathrm{Al}$ alloys, sulfidation of iron-aluminide weld overlays, and corrosion of several iron-aluminum alloys in a simulated coal gasification environment in which the chlorine level was varied.

\section{OXIDATION OF ODS Fe 3 Al ALLOYS}

As described elsewhere, ${ }^{4}$ ODS $\mathrm{Fe}_{3} \mathrm{Al}$ alloys are currently being developed to increase the operating temperature regime of these uniquely sulfidation-resistant materials. Determining the effects of a dispersion of oxides on the high-temperature oxidation resistance of $\mathrm{Fe}_{3} \mathrm{Al}$ is a key part of this effort. Use of a reactive element (RE) oxide may further improve the adhesion of alumina scales on iron aluminides, as has been shown for the FeCrAl, NiCrAl, and NiAl systems (see, for example, refs. 5-7). The initial results on the effects of $\mathrm{Y}_{2} \mathrm{O}_{3}, \mathrm{CeO}_{2}$, 
and $\mathrm{La}_{2} \mathrm{O}_{3}$ on high-temperature cyclic oxidation of Fe-28\% Al-2\% Cr (FAS) are summarized here. More details of the work with the $\mathrm{Y}_{2} \mathrm{O}_{3}$ and $\mathrm{CeO}_{2}$-doped FAS can be found in ref. 8 .

Powders of gas-atomized FAS and submicron oxides $\left(\mathrm{Y}_{2} \mathrm{O}_{3}, \mathrm{CeO}_{2}\right.$, or $\left.\mathrm{La}_{2} \mathrm{O}_{3}\right)$ were mechanically blended in a flowing Ar atmosphere using a high-speed attritor and stainless steel balls. (Unless otherwise noted, all concentrations are in at.\%). The blended powder was canned, degassed, and extruded at $1100^{\circ} \mathrm{C}$. For comparison, a FAS powder extrusion without an oxide addition, ingot-processed $\mathrm{Fe}-28 \% \mathrm{Al}-5 \% \mathrm{Cr}-0.1 \% \mathrm{Zr}$ (FAL), and a commercial $\mathrm{ZrO}_{2}$-dispersed $(0.06 \% \mathrm{Zr}) \mathrm{Fe}-20 \% \mathrm{Cr}-10 \% \mathrm{Al}$ alloy (Kanthal alloy APM) were also tested. Coupons (about $15 \mathrm{~mm}$ diam $\times 1 \mathrm{~mm}$ thick) were polished with $0.3 \mu \mathrm{m}$ alumina prior to oxidation. Cyclic oxidation experiments were conducted at $1200^{\circ} \mathrm{C}$ in air and in dry, flowing $\mathrm{O}_{2}$. Admittedly, the exposure temperature of $1200^{\circ} \mathrm{C}$ is significantly higher than most potential applications for iron aluminides, but it is a convenient way to assess the potential lifetime of these materials based on aluminum consumption. A similar approach was previously used to predict oxidative lifetimes for ingot-processed iron aluminides and for comparison with $\mathrm{FeCrAl}$ alloys. ${ }^{9}$ In short-term cyclic testing $(2 \mathrm{~h}$ cycles), specimens were hung in a furnace in flowing $\mathrm{O}_{2}$ and weight changes were measured continuously using a microbalance to check for any indication of isothermal spallation. (However, spallation was only observed upon cooling.) In long-term testing (100 h cycles), specimens were placed in a static air furnace inside individual alumina crucibles so that any spalled oxide was collected and weighed. In both types of tests, the specimen weight changes were measured before and after oxidation. After oxidation, specimens were examined using scanning electron microscopy (SEM) with energy dispersive $x$-ray (EDX) analysis.

Specimen weight change data for the various alloys exposed to $2 \mathrm{~h}$ cycles are shown in Fig. 1. A fine powdery alumina scale formed on the undoped FAS alloy and led to large weight losses after just a few cycles. In contrast, rapid weight gains were observed for the $\mathrm{CeO}_{2}$ - and $\mathrm{La}_{2} \mathrm{O}_{3}$-dispersed alloy specimens. The $\mathrm{CeO}_{2}$-dispersed alloy exposure was stopped after 14 cycles when breakaway oxidation (formation of $\mathrm{FeO}_{\mathrm{x}}$ ) began at one edge. The detrimental effects of $\mathrm{CeO}_{2}$ and $\mathrm{La}_{2} \mathrm{O}_{3}$ are comparable to that of $\mathrm{La}_{2} \mathrm{O}_{3}$ in $\beta-\mathrm{NiAl}^{7}$ In all these cases, the additions resulted in accelerated oxidation relative to the undoped alloy. Whether this effect is primarily in the oxide or in the alloy is unclear and is under investigation.

All cyclically exposed alloys had some scale loss except for the $\mathrm{ZrO}_{2}$-dispersed $\mathrm{FeCrAl}$ and the FAS with $0.05 \%$ of $\mathrm{Y}$ cations. Of the $\mathrm{Y}_{2} \mathrm{O}_{3}$-dispersed FAS alloys, the $0.2 \% \mathrm{Y}$ addition had the largest amount of scale spallation (about $40 \%$ of area), in agreement with the weight change measurements shown in Fig. 1. In general, spallation to bare metal was 


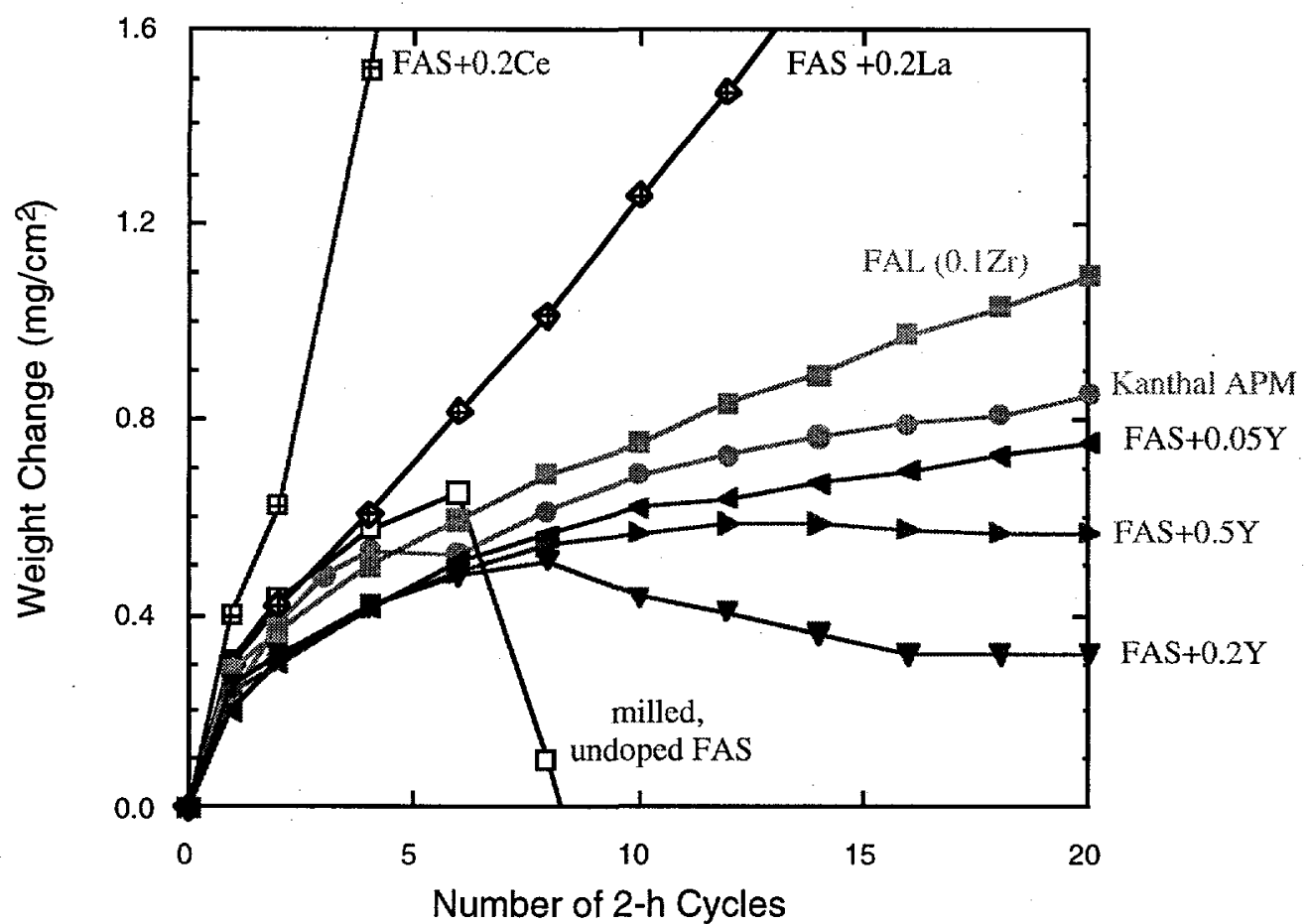

Fig. 1. Short-term specimen weight changes upon cyclic oxidation at $1200^{\circ} \mathrm{C}$ in $\mathrm{O}_{2}$ for iron aluminides with various oxide dispersions.

observed and voids at the metal-oxide interface were apparent. However, compared to the undoped alloy, all of the $\mathrm{Y}_{2} \mathrm{O}_{3}$ additions to FAS reduced the amount of scale spallation. Also, Y doping produced a flatter, less convoluted scale than that observed on the undoped FAS, as does $\mathrm{Zr}$ in the ingot-processed FAL.

The longer-term cyclic oxidation results are shown in Fig. 2. In contrast to the data in Fig. 1, the specimens were exposed for $100 \mathrm{~h}$ each time and the reported results represent total mass change (specimen plus any spalled oxide). In this way, the measurements are proportional to the amount of metal consumed by oxidation. Comparing these total weight gains, the alloy with the smallest $\mathrm{Y}_{2} \mathrm{O}_{3}$ addition $(0.05 \% \mathrm{Y})$ performed worst and that with the $0.2 \% \mathrm{Y}$ had the best behavior, which is the opposite result of the short-term oxidation results (Fig. 1). Nevertheless, $\mathrm{Y}_{2} \mathrm{O}_{3}$ additions still improved oxidation resistance relative to the undoped FAS alloy, which went into breakaway oxidation after three cycles. The ability to increase the effectiveness of yttria, and possibly other oxides, in increasing the oxidation resistance of iron aluminides by improving dispersion uniformity and controlling microstructure is currently under study.

The rate at which aluminum in the alloy is consumed is a critical factor in predicting time to breakaway oxidation (as defined above) and the higher $\mathrm{Al}$ content of iron 


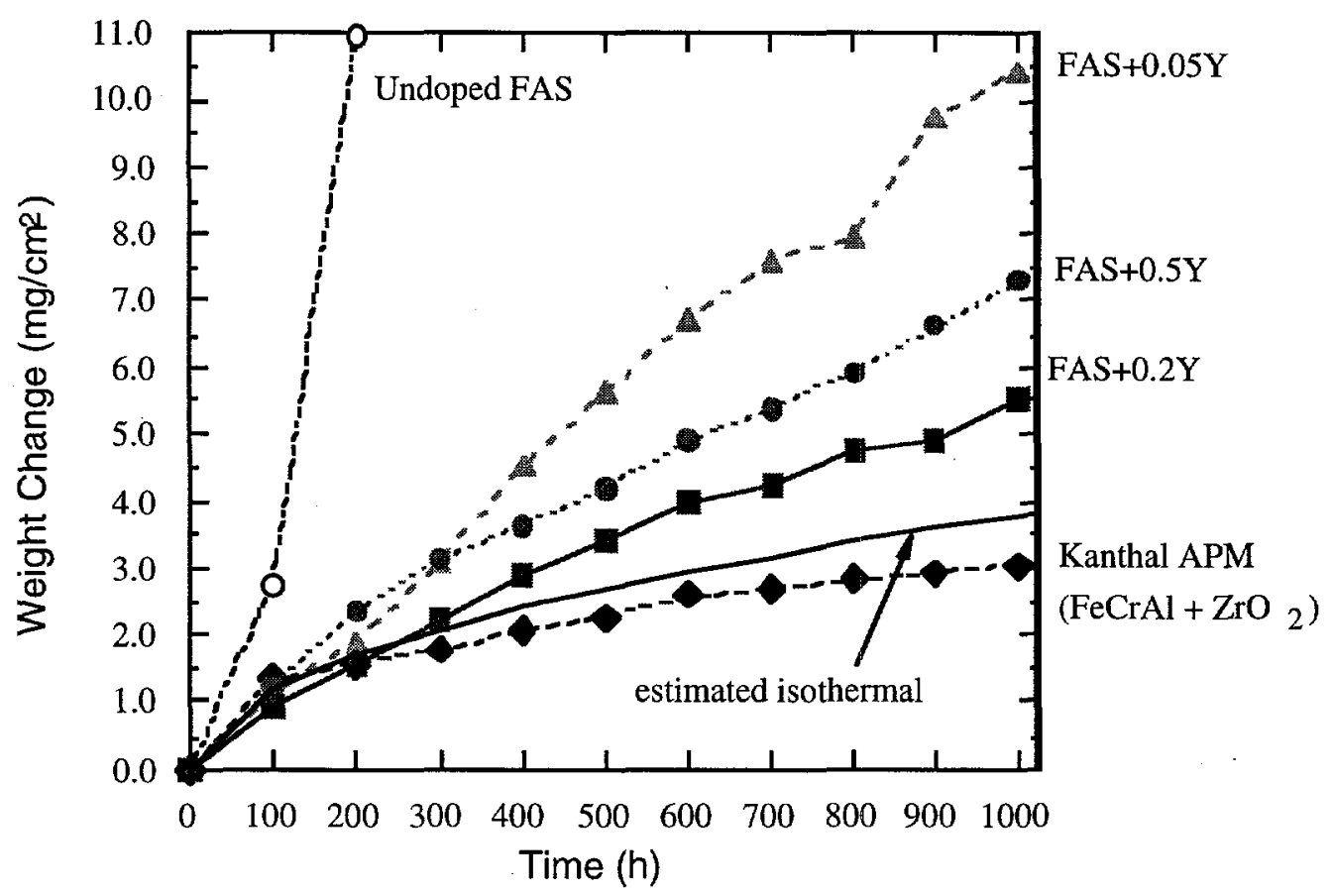

Fig. 2. Total weight gain (including spalled scale) for 100 -h cycles at $1200^{\circ} \mathrm{C}$ in air.

aluminides relative to $\mathrm{FeCrAl}$ alloys could result in longer oxidative lifetimes. However, scale spallation was more severe for the $\mathrm{Y}_{2} \mathrm{O}_{3}$-doped FAS alloys than for the $\mathrm{ZrO}_{2}$-dispersed $\mathrm{FeCrAl}$ and, based on the total weight gains (Fig. 2), the aluminum consumption rate was 2 to 4 times higher for the former materials. In previous work on ODS FeCrAl and $\beta-\mathrm{NiAl}$ alloys, ${ }^{10} \mathrm{Y}$ and $\mathrm{Zr}$ dopants were found to have identical beneficial effects on the oxidation behavior. Thus, it appears that the difference in oxidation behavior between the ODS FeCrAl and $\mathrm{Fe}_{3} \mathrm{Al}$ alloys cannot be explained by the difference in their dopant oxides. Furthermore, the $\mathrm{Zr}$-containing FAL suffered greater cyclic weight gains and scale spallation than the $\mathrm{Zr}$ doped $\mathrm{FeCrAl}$ alloy (Fig. 1). A similar result was also observed for $1300^{\circ} \mathrm{C}$ oxidative lifetime testing: ${ }^{9}$ despite the lower $\mathrm{Al}$ content of a RE-doped FeCrAl alloy, its time to breakaway oxidation was comparable to that for ingot-processed $\mathrm{FAL}$ containing $0.1 \% \mathrm{Zr}$, thereby indicating a higher Al consumption rate for the FAL alloy.

\section{OXIDATION-SULFIDATION OF IRON-ALUMINIDE WELD OVERLAYS AT $800^{\circ} \mathrm{C}$}

The oxidation and sulfidation resistance of iron aluminides containing greater than 18 25 at.\% $\mathrm{Al}$ is maintained at temperatures (for example, $800^{\circ} \mathrm{C}$ ) well above those at which these alloys have adequate mechanical strength. Because of this, and possible cost considerations, it 
is anticipated that appropriate compositions of iron aluminides may find application as coatings or claddings on more conventional higher-strength materials which are less corrosion-resistant at high temperatures. Initial work in this regard focused on examining the sulfidation resistance of iron-aluminide coatings deposited by a weld-overlay technique.

Weld-overlay deposits of Fe-Al alloys were produced on 25 mm-thick $2.25 \mathrm{Cr}-1 \mathrm{Mo}$ (wt\%) steel and $50 \mathrm{~mm}$-thick type 304 stainless steel substrates using techniques and filler materials described elsewhere. ${ }^{11,12}$ Rectangular pieces, approximately $18 \times 12 \mathrm{~mm}$, were cut from the weld overlay specimens. Coupons for the corrosion experiments were then prepared by grinding away the substrate material so that they consisted of only weld metal (approximately $1-2 \mathrm{~mm}$ thick). Corrosion behavior was characterized by use of a continuous-recording microbalance to measure the weight of these specimens during exposure at $800^{\circ} \mathrm{C}$ to a flowing $\left(\sim 2 \mathrm{~cm}^{3} / \mathrm{s}\right)$ mixed gas consisting of $5.4 \% \mathrm{H}_{2} \mathrm{~S}-79.4 \% \mathrm{H}_{2}$ $1.6 \% \mathrm{H}_{2} \mathrm{O}-13.6 \% \mathrm{Ar}$ (by volume). The oxygen partial pressure, as determined by a solidstate oxygen cell, was $10^{-22} \mathrm{~atm}$, and the sulfur pressure was calculated to be $10^{-6} \mathrm{~atm}$. This type of experiment has been used to characterize the sulfidation resistance of many iron aluminides and several other alloys. ${ }^{3,13,14}$ Due to mixing during welding, the composition of a particular weld overlay depends not only on the elements present in the filler metal but also on the alloy used as the substrate. ${ }^{11,12}$ Therefore, it was important to determine the actual concentrations of the appropriate elements in the deposited layers and these are shown in Table 1.

Table 1. Weld Deposit Compositions

\begin{tabular}{|c|c|c|c|c|c|c|c|c|c|}
\hline \multirow{2}{*}{$\begin{array}{l}\text { Spec- } \\
\text { imen }\end{array}$} & \multirow{2}{*}{$\begin{array}{l}\text { Sub- } \\
\text { strate }\end{array}$} & \multicolumn{8}{|c|}{ Concentration (at. $\%)^{a}$} \\
\hline & & Al & $\mathbf{C r}$ & $\mathbf{N b}$ & Ti & $\mathbf{N i}$ & Mo & $\mathbf{Z r}$ & C \\
\hline $\mathrm{C} 1$ & Cr-Mo & 35.4 & 2.5 & 0.2 & 0.4 & - & 0.6 & 0.2 & 1.0 \\
\hline $\mathrm{C} 2$ & Cr-Mo & 36.7 & 4.7 & 0.2 & 0.4 & - & 0.6 & 0.2 & 1.0 \\
\hline C3 & $\mathrm{Cr}-\mathrm{Mo}$ & 35.5 & 0.7 & - & - & - & 0.7 & 0.1 & 1.0 \\
\hline $\mathrm{O} 1$ & 304 & 11.1 & 6.7 & $<0.01$ & $<0.01$ & 6.6 & 0.2 & 0.03 & 0.5 \\
\hline $\mathrm{O} 2$ & 304 & 23.1 & 6.3 & 0.1 & 0.1 & 6.3 & 0.2 & 0.1 & 0.5 \\
\hline $\mathrm{O} 3$ & $\mathrm{Cr}-\mathrm{Mo}$ & 21.7 & 2.1 & 0.1 & - & - & 0.7 & 0.1 & - \\
\hline
\end{tabular}

$a$ Determined by spark source mass spectrometry. Balance is Fe. 
The weight change results for the six overlay coatings exposed to $\mathrm{H}_{2} \mathrm{~S}-\mathrm{H}_{2}-\mathrm{H}_{2} \mathrm{O}-\mathrm{Ar}$ at $800^{\circ} \mathrm{C}$ are shown in Fig. 3. The curves clearly fell into groups of either low (C1, C2, C3) or high (O1, O2, O3) weight gains. Figure 4 presents a more detailed view of the thermogravimetric data for the coupons in the low weight-gain group and, for the sake of comparison, includes two curves for specimens of wrought FAS. This composition has been shown to be among the most corrosion-resistant $\mathrm{Fe}_{3} \mathrm{Al}$ alloys in this gas mixture. ${ }^{14}$

Differences in corrosion behavior between the $\mathrm{C}$ and $\mathrm{O}$ groups of specimens were also reflected in the respective corrosion product morphologies. ${ }^{15}$ The higher-aluminum specimens exhibited thin, fairly uniform scales with just a small amount of powdery, spalled scale. In contrast, significant scale loss (upon cooling and handling), were observed for the three coatings with lower aluminum concentrations. Specimens $\mathrm{O} 1$ and $\mathrm{O} 2$ had relatively thick, black corrosion products which consisted of dense mattes of aluminum and iron sulfides, as determined by EDX analyses in a SEM. Specimen O3 exhibited a smaller population of the same type of sulfides.

Based on findings from previous iron-aluminide studies, 3,14 the corrosion data shown in Figs. 3 and 4 are consistent with the deposit compositions recorded in Table 1. The coatings exhibiting relatively high weight gains and corrosion rates $(\mathrm{O} 1, \mathrm{O} 2, \mathrm{O} 3)$ have relatively low aluminum and high chromium concentrations. In the case of $\mathrm{O} 1$, the aluminum content is very much lower than what has been found to be needed for the best sulfidation resistance, ${ }^{16}$ while $\mathrm{O} 2$ and $\mathrm{O} 3$ exceed this critical concentration somewhat. As expected, $\mathrm{O} 1$ showed the greatest sulfidation susceptibility of the group $\mathrm{O}$ specimens due to its low aluminum concentration. The somewhat worse behavior of $\mathrm{O} 2$ vis-à-vis $\mathrm{O} 3$ is probably due to the higher chromium and nickel concentrations of the former. Chromium levels similar to that in $\mathrm{O} 2$ exacerbate the sulfidation reaction for $\mathrm{Fe}_{3} \mathrm{Al}$ alloys. ${ }^{14}$ While the three weld clads with the lower aluminum concentrations exhibited substantial mass gains, their relative corrosion resistance was still somewhat better than that of $\mathrm{Fe}-\mathrm{Cr}-\mathrm{Ni}$ alloys. ${ }^{13,14}$

The specimens denoted $\mathrm{C} 1, \mathrm{C} 2$, and $\mathrm{C} 3$ all have aluminum concentrations well in excess of the critical amount needed for excellent sulfidation resistance in the subject mixed gas. ${ }^{16}$ Their oxidation/sulfidation behavior therefore resembles that of the most resistant iron aluminides. ${ }^{14}$ The deleterious effect of $\mathrm{Cr}$ is normally not observed at the higher aluminum levels in the group $\mathrm{C}$ specimens ${ }^{3,14}$ and little, if any, detrimental influence of the higher chromium concentration of $\mathrm{C} 2$ was detected (Fig. 4). Compared with the results shown in Fig. 3, the weight gains and rates in Fig. 4 are low; differences among the curves are not statistically significant. 


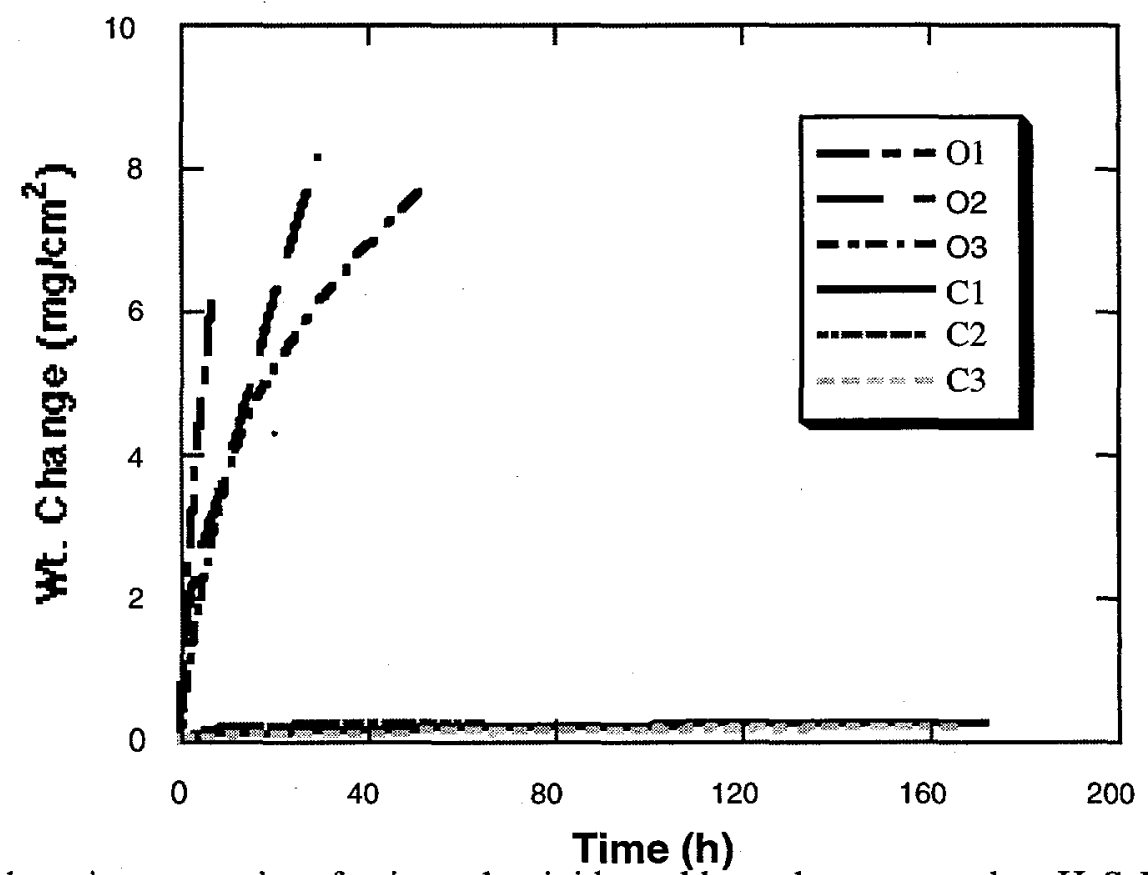

Fig 3. Weight gain versus time for iron-aluminide weld overlays exposed to $\mathrm{H}_{2} \mathrm{~S}-\mathrm{H}_{2}-\mathrm{H}_{2} \mathrm{O}$ at $800^{\circ} \mathrm{C}$. Overlay compositions are shown in Table 1.

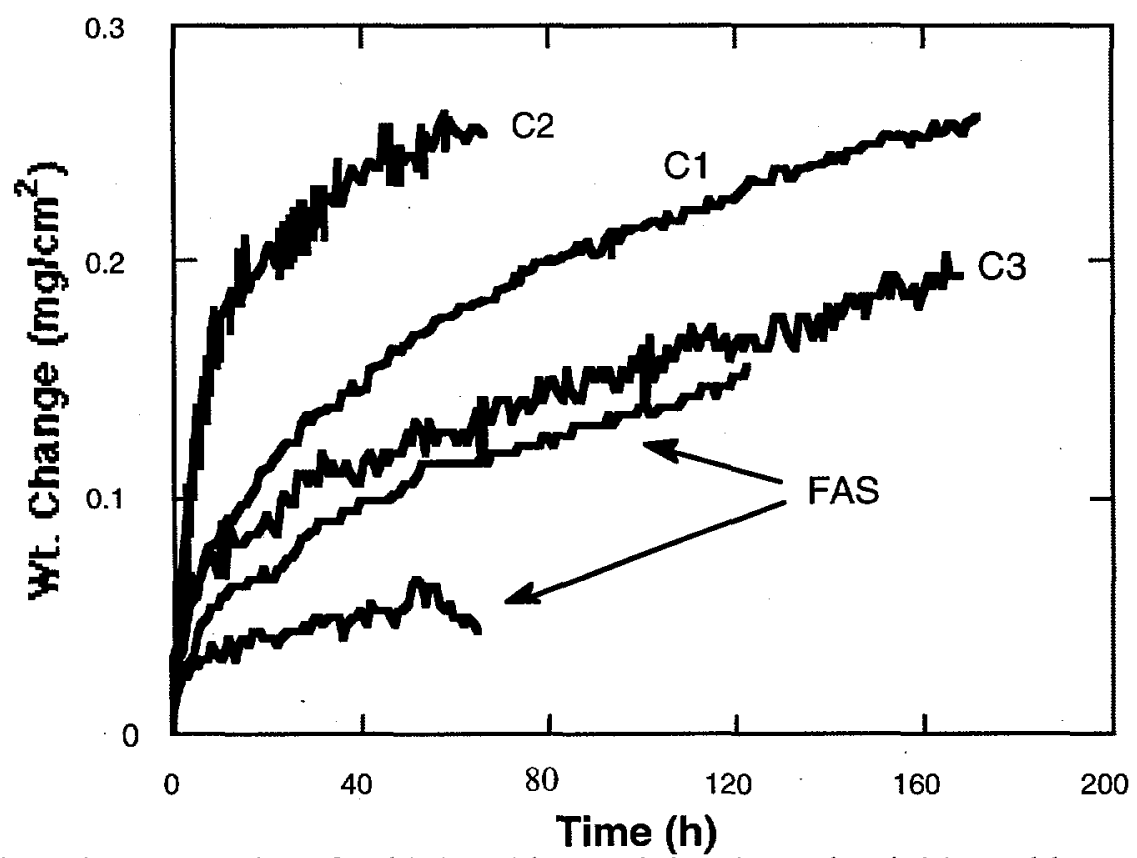

Fig. 4. Weight gain versus time for higher-Al-containing iron-aluminide weld overlays and alloy FAS exposed to $\mathrm{H}_{2} \mathrm{~S}-\mathrm{H}_{2}-\mathrm{H}_{2} \mathrm{O}$ at $800^{\circ} \mathrm{C}$. Overlay compositions are shown in Table 1 . 
The present results show that iron-aluminide weld overlays have the potential to be effective corrosion-resistant coatings in high-temperature sulfidizing environments provided the appropriate combinations of filler metal, process parameters, and substrate are used to produce adequate aluminum concentrations and minimal chromium contents. In the present study, the spread in aluminum concentration between the group $\mathrm{O}$ and $\mathrm{C}$ specimens is too large to precisely define the clad composition necessary to achieve low corrosion rates. The higher aluminum concentrations of the group $\mathrm{C}$ specimens would provide a margin of safety with respect to sulfidation resistance, particularly in view of enrichment of the weld overlay in substrate elements (for example, chromium and nickel) that are deleterious to sulfidation resistance. Furthermore, excess aluminum would delay any onset of breakaway oxidation caused by aluminum depletion. ${ }^{9}$ However, weld deposits containing high aluminum concentrations are much more sensitive to hydrogen-induced cracking when exposed to moist air, even after stress relief. In this regard, it must be noted that, as oniy the coatings themselves were tested in the corrosive environment, the present study was focused on the thermodynamic stability and reaction kinetics of the weld deposits and did not examine the effects of extended defects. The actual protectiveness of a particular layer will also depend on the ability of these layers to provide a physical barrier that doesn't delaminate or allow corrosion of the substrate by ingress of reactive species via cracks or other defects. These aspects will be investigated through exposure of clad substrates to the particular corrosive environment.

\section{EFFECT OF CHLORINE ON THE OXIDATION-SULFIDATION OF IRON ALUMINIDES AT 450 AND $550^{\circ} \mathrm{C}$}

In some fossil energy applications, iron aluminides will have to show corrosion resistance to product gases that contain small concentrations of $\mathrm{HCl}$ in an oxidizing-sulfidizing atmosphere of relatively high $\mathrm{pS}_{2}$ and low $\mathrm{PO}_{2}$. Because of this, the effect of $\mathrm{HCl}$ on the corrosion of FAS, FA129 (Fe-28\% Al-5\% Cr-0.5\% Nb- $0.2 \% \mathrm{C}$ ), and FAP (Fe-16\% Al$5 \% \mathrm{Cr}-1.1 \% \mathrm{Mo}-0.1 \% \mathrm{Zr}-0.1 \% \mathrm{C}$ ) in a simulated coal gasification environment has been studied in collaboration with the National Physical Laboratory (NPL) in the United Kingdom. The sulfur and oxygen fugacities of the gas were, respectively, $5 \times 10^{-8}$ and $1 \times 10^{-26}$ at $450^{\circ} \mathrm{C}$ and $2 \times 10^{-6}$ and $2 \times 10^{-22}$ at $550^{\circ} \mathrm{C}$. Two levels of $\mathrm{HCl}$ additions, 1000 and 3283 ppm, were examined. General details of the experiments and initial results (for $1000 \mathrm{ppm}$ $\mathrm{HCl}$ ) have been described previously. ${ }^{9}$ A FeCrAlY alloy was included in the exposures for comparison. 
Gravimetric results for exposures in the mixed gas with $3283 \mathrm{ppm}$ of $\mathrm{HCl}$ are shown in Fig. 5. As with the results for mixed gas with $1000 \mathrm{ppm} \mathrm{HCl},{ }^{9}$ weight changes of FAP were substantially higher than those of the other three alloys and, at $550^{\circ} \mathrm{C}, \mathrm{FAS}$ and FA129 performed somewhat better than the FeCrAlY. Differences in corrosion susceptibility are also shown in Fig. 6, which contains representative cross sections of exposed aluminides. Thin, presumably alumina, scales formed on FAS and FA129 (Fig. 6a and b) and provided adequate protection. Penetration along a few grain boundaries was noted. Such attack has not been noticed for sulfidation of iron aluminides at higher temperatures in the absence of $\mathrm{HCl}$, but the present observations of such were limited to a small fraction of the exposed surface area. In contrast, FAP (Fig. 6c) exhibited significantly thicker scales that included sulfides. The reaction product on the FeCrAlY was thinner than that on FAP, but thicker than those found on FAS and FA129, which is consistent with the gravimetric data for the $550^{\circ} \mathrm{C}$ exposures in the environments with $\mathrm{HCl}$ at concentrations of $1000 \mathrm{ppm}$ (ref. 9) and 3283 ppm (Fig. 5).

In studies conducted in a similar type of mixed-gas at $800^{\circ} \mathrm{C}$, but without $\mathrm{HCl}$ additions, both higher chromium levels $(>2 \%)$ and lower aluminum concentrations $(<\sim 18 \%)$ contributed to reduced resistance to corrosion. ${ }^{3,14,16}$ In the case of the present exposures, a concentration of $5 \% \mathrm{Cr}$ in $\mathrm{Fe}_{3} \mathrm{Al}$ (FA129), which reduces sulfidation resistance at higher temperatures, did not have a significant effect at 450 and $550^{\circ} \mathrm{C}$ in the presence of $\mathrm{HCl}$. Additionally, the substantial chromium concentration $(\sim 20 \%)$ of the FeCrAlY, which has a dramatic deleterious effect in the aforementioned high-temperature sulfidizing environment, $3,14,16$ appears to have only a minor influence in the mixed gas $+\mathrm{HCl}$; the corrosion susceptibility of this alloy was similar to that of FAS and FA129 at $450^{\circ} \mathrm{C}$ and only moderately worse at $550^{\circ} \mathrm{C}$. On the other hand, the lower aluminum concentration of FAP $(16 \%)$ appears to have been a major factor in its relatively poor performance under these conditions, as well as at higher temperatures. 3,16

\section{SUMMARY AND CONCLUSIONS}

Oxide-dispersed $\mathrm{Fe}-28 \% \mathrm{Al}-2 \% \mathrm{Cr}$ alloys doped with $\mathrm{Y}_{2} \mathrm{O}_{3}, \mathrm{CeO}_{2}$, and $\mathrm{La}_{2} \mathrm{O}_{3}$ were prepared and cyclically oxidized at $1200^{\circ} \mathrm{C}$. Yttria improved scale adhesion relative to the undoped alloy, but was not as effective as zirconia in an $\mathrm{FeCrAl}$ alloy. Both $\mathrm{CeO}_{2}$ and $\mathrm{La}_{2} \mathrm{O}_{3}$ were detrimental to oxidation behavior. 


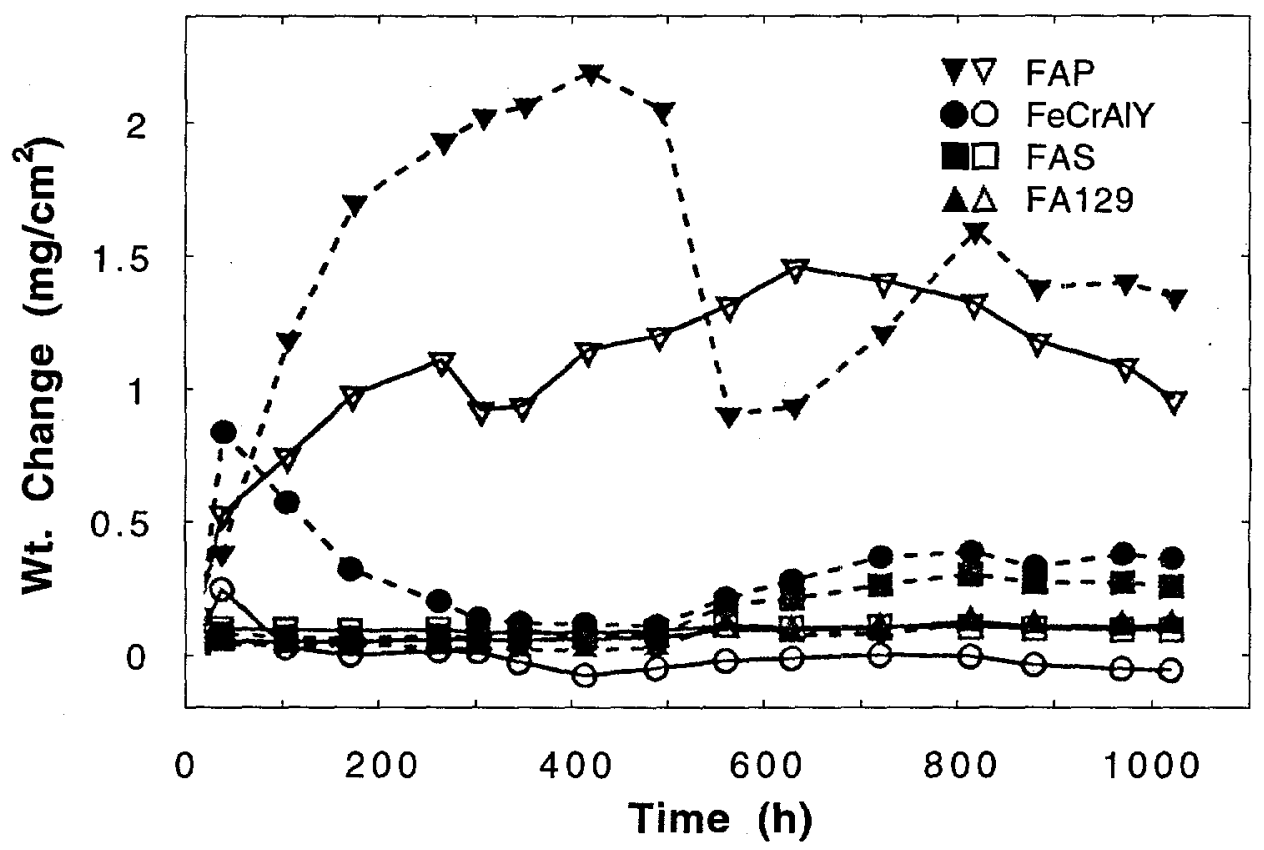

Fig. 5. Weight changes vs. time for exposures in a simulated coal-gasification environment containing $3283 \mathrm{ppm} \mathrm{HCl}$ at $550^{\circ} \mathrm{C}$.

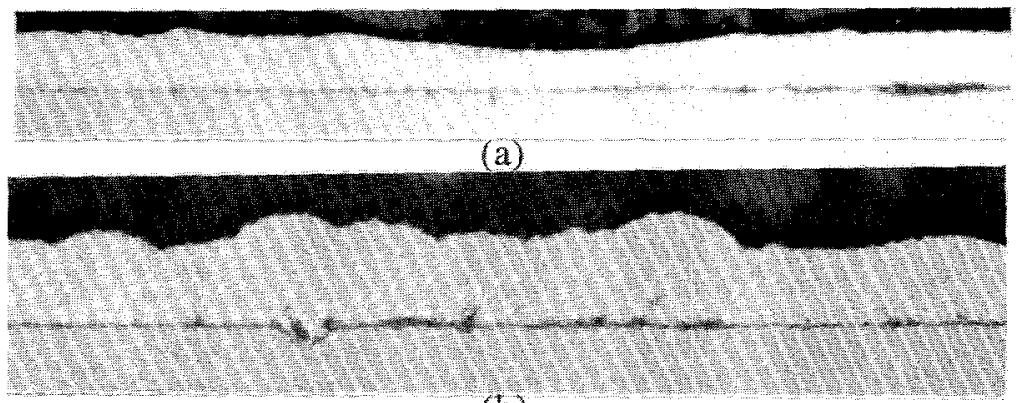

(b)

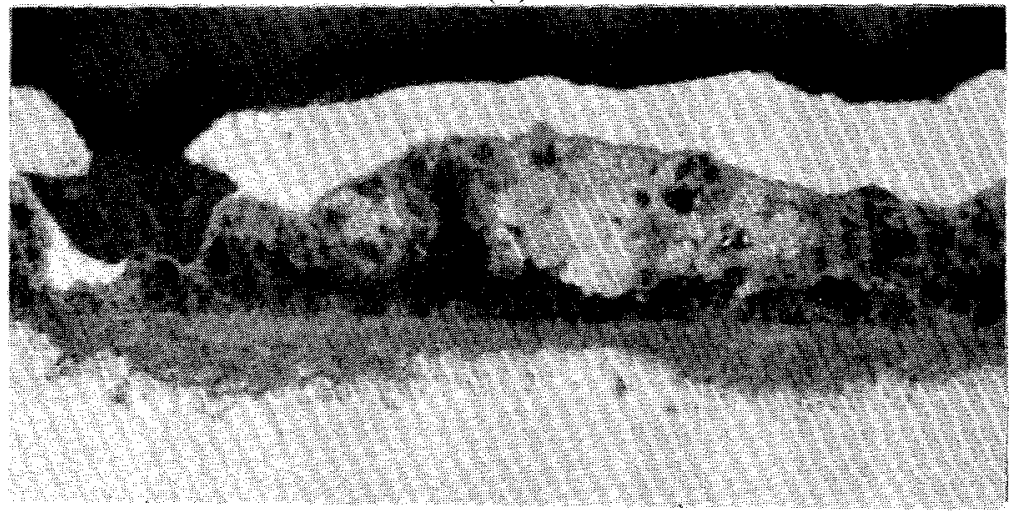

(c)

$10 \mu \mathrm{m}$

Fig. 6 Polished cross sections of iron aluminides exposed in a simulated coal-gasification environment containing $3283 \mathrm{ppm} \mathrm{HCl}$ at $550^{\circ} \mathrm{C}$ for $1007 \mathrm{~h}$. The specimens were coated with copper prior to sectioning (visible as bright topcoat). (a) FAS (b) FA129 (c) FAP 
Specimens of weld-overlay iron-aluminide coatings were exposed to $\mathrm{H}_{2} \mathrm{~S}-\mathrm{H}_{2}-\mathrm{H}_{2} \mathrm{O}-\mathrm{Ar}$ at $800^{\circ} \mathrm{C}$. The investigation focused only on the weld overlay material and, as such, involved the characterization of the thermodynamic and kinetic stabilities of these coatings rather than their ability to physically separate the corrosive species from susceptible substrate material. Under conditions that produced coatings with sufficiently high aluminum concentrations, corrosion resistance equivalent to the best bulk iron aluminides was found.

Three iron aluminides and a standard FeCrAlY alloy were exposed at 450 and $550^{\circ} \mathrm{C}$ in an oxidizing/sulfidizing environment containing varying amounts of $\mathrm{HCl}$ at the National Physical Laboratory in the United Kingdom. Two 28\% Al - 5\% Cr alloys, FA129 and FAL, were more resistant than $\mathrm{FeCrAlY}$ at $550^{\circ} \mathrm{C}$ and $\mathrm{Fe}-16 \% \mathrm{Al}-5 \% \mathrm{Cr}$ (FAP) at both temperatures. For FA129 and FAL, there was little evidence to suggest any accelerating effect of $\mathrm{HCl}$ up to a concentration of about $3300 \mathrm{ppm}$.

\section{ACKNOWLEDGMENTS}

The authors thank M. Howell for experimental support and J. R. DiStefano, G. M. Goodwin, and C. G. McKamey for their reviews of the manuscript. This research was sponsored by the Fossil Energy Advanced Research and Technology Development (AR\&TD) Materials Program, U S. Department of Energy, under contract DE-AC05-84OR21400 with Martin Marietta Energy Systems, Inc. B. A. Pint is supported by the U S. Department of Energy Distinguished Postdoctoral Research Program administered by the Oak Ridge Institute for Science and Education.

\section{REFERENCES}

1. C. G. McKamey, J. H. DeVan, P. F. Tortorelli, and V. K. Sikka, J. Mater. Res. 6, 1779 (1991). 105 .

2. P. Tomaszewicz and G. R. Wallwork, Rev. High Temp. Materials 4, 75 (1978) 75-

3. P. F. Tortorelli and J. H. DeVan, pp. 257-70 in Processing, Properties, and Applications of Iron Aluminides, J. H. Schneibel and M. A. Crimp (eds.), The Minerals, Metals, and Materials Society, Warrendale, PA, 1994.

4. I. G. Wright, C. G. McKamey, and B. A. Pint, "ODS Iron Aluminides," these proceedings.

5. W. J. Quadakkers, K. Schmidt, H. Grubmeier, and E. Wallura, Mater. High. Temperature 10, 23 (1992).

6. H. T. Michels, Metall. Trans. A 9A, 873 (1978)

7. B. A. Pint and L. W. Hobbs, pp. 987-92 in High-Temperature Ordered Intermetallic Alloys VI, J. A. Horton, I. Baker, S. Hanada, R. D. Noebe, and D. S. Schwartz (eds.), The Materials Research Society, Pittsburgh, PA, 1995.

8. B. A. Pint, K. B. Alexander, and P. F. Tortorelli, "The Effect of Various Oxide Dispersions on the Oxidation Resistance of $\mathrm{Fe}_{3} \mathrm{Al}$," pp. 1315-20 in High-Temperature Ordered Intermetallic Alloys VI, J. A. Horton, I. Baker, S. Hanada, R. D. Noebe, and D. S. Schwartz (eds.), The Materials Research Society, Pittsburgh, PA, 1995. 
9. J. H. DeVan, P. F. Tortorelli, and M. J. Bennett, pp. 309-20 in Proc. Eighth Annual Conf. Fossil Energy Materials, N. C. Cole and R. R. Judkins (comp.), CONF-9405143, U. S. Department of Energy, August 1994.

10. B. A. Pint, Oxid. Met. 44, (1995) in press.

11. G. M. Goodwin, P. J. Masiasz, C. G. McKamey, J. H. DeVan, and V. K. Sikka, pp. 205-10 in Proc. Eighth Annual Conf. Fossil Energy Materials, N. C. Cole and R. R. Judkins (comp.), U. S. Department of Energy, 1994.

12. G. M. Goodwin, "Weld Overlay Cladding With Iron Aluminides," these proceedings 13. J. H. DeVan, H. S. Hsu, and M. Howell, Oak Ridge National Laboratory report, ORNL/TM-11176, May 1989.

14. J. H. DeVan, pp. 107-115 in Oxidation of High-Temperature Intermetallics, T. Grobstein and J. Doychak (eds.), The Minerals, Metals, and Materials Society, 1989.

15. P. F. Tortorelli, J. H. DeVan, G. M. Goodwin, and M. Howell, accepted for publication in High-Temperature Coatings I, N. B. Dahotre, J. Hampikian, and J. J. Stiglich (eds.), The Minerals, Metals, and Materials Society, Warrendale, PA, 1994.

16. J. H. DeVan and P. F. Tortorelli, Corros. Sci. 35, 1065 (1993). 


\subsection{ODS IRON ALUMINIDES}

\section{G. Wright, C. G. McKamey, and B. A. Pint}

\section{INTRODUCTION}

There has been a recent increase of interest in advanced cycles that involve indirectlyfired gas turbines, in which coal- or gas-fired high-temperature heat exchangers are used to heat a working fluid in a closed system ${ }^{1}$. In a program conducted as part of the European COST-501 Concerted Action Project (Round 2, Work Package 4), available alloys based on FeCrAl- $\mathrm{Y}_{2} \mathrm{O}_{3}$ (listed in Table 1) were evaluated for use in the main heat exchanger in a similar closed-cycle gas turbine application $2,3,4,5,6,7,8,9,10,11,12$. One of the currently available ODS FeCrAl alloys was found to meet the strength requirements for this application, in which the working fluid at 0.9 $\mathrm{MPa}(131 \mathrm{psi})$ flowing at $5,889 \mathrm{~kg} / \mathrm{hr}(12,955 \mathrm{lb} / \mathrm{hr})$ was to be heated from 800 to $1100^{\circ} \mathrm{C}(1472$ to $\left.2012^{\circ} \mathrm{F}\right)$ over a tube length of $4 \mathrm{~m}(13 \mathrm{ft})$.

Table 1. Nominal Compositions of Available Ferritic ODS Alloys (weight percent)

$\begin{array}{lcccccc}\quad \text { Alloy } & \text { Fe } & \text { Cr } & \text { Al } & \text { Mo } & \text { Ti } & \mathbf{Y}_{2} \mathbf{O}_{3} \\ \text { MA 956 } & \text { Bal } & 20.0 & 4.5 & - & 0.5 & 0.5 \\ \text { PM 2000 } & \text { Bal } & 20.0 & 5.5 & - & 0.5 & 0.5 \\ \text { ODM 751 } & \text { Bal } & 16.5 & 4.5 & 1.5 & 0.6 & 0.5 \\ \text { ODM 331 } & \text { Bal } & 13.0 & 3.0 & 1.5 & 0.6 & 0.5\end{array}$

FeCrAl-based alloys have long been regarded as having excellent resistance to hightemperature oxidation, with reactive metal or reactive metal oxide additions playing some beneficial role13,14,15. However, much of the information on oxidation behavior was generated from relatively short-term exposures, however. In the very high-temperature heat exchanger application, an area of unexpected but major concern with these alloys is their ability to maintain a protective oxide scale for the extended times necessary for commercial application. After extended exposure times, these alloys suffer increasing loss of scale through spallation, as indicated by the trend to weight losses as shown in Fig. 1. The oxidation life of these alloys is determined by their ability to form or reform a protective alumina scale, and can be related to the time for the aluminum content of the alloy to be depleted to some minimum level; this, in turn, is a function of the total aluminum content of the alloy. This dependence on total available aluminum content is illustrated by results 8 from the COST-501 project as summarized in Fig. 2, which relates the effective life of the alloy tube (represented as 'time to breakaway') to its wall thickness. 
The major factors that result in depletion of the reservoir of aluminum in the alloy are the inherent growth rate of the oxide, a process that consumes aluminum, and the tendency for the scale to spall, which also results in a net loss of aluminum from the alloy together with a (temporary) increase in oxide growth rate in the area affected by spallation. When the alloy aluminum reservoir falls below the minimum level at which an alumina layer can be reformed, less-protective oxides of the other alloy constituents will form in areas where the initial scale spalls, and the rate of oxidation may rapidly increase as the alloy undergoes 'breakaway' oxidation. A further complication is that, according to results from the COST-501 project, differences among alloys that are insignificant for oxidation growth rate and tendency to spall can dramatically affect the time to breakaway. Hence, similar components manufactured from alloys of nominally similar compositions may fail at quite different times.

Iron-aluminum alloys have the obvious potential to provide longer service lives because of their inherently larger aluminum reservoirs (15.8 vs 3 to $5.5 \mathrm{wt} . \% \mathrm{Al})$, provided that their oxidation and mechanical properties are similar to the FeCrAl-based alloys. Iron-aluminum alloys have been regarded for many years as having excellent resistance to high-temperature oxidation 16,17,18,19, and this has been confirmed by the recent work at $\mathrm{ORNL}$ on $\mathrm{Fe}_{3} \mathrm{Al}$ alloys ${ }^{20}$. However, until that recent work, the development of usable ferritic alloys was restricted by their poor mechanical properties, especially the lack of ambient-temperature ductility which impaired fabricability. The lack of strength at temperatures above about $600^{\circ} \mathrm{C}$ is still a problem

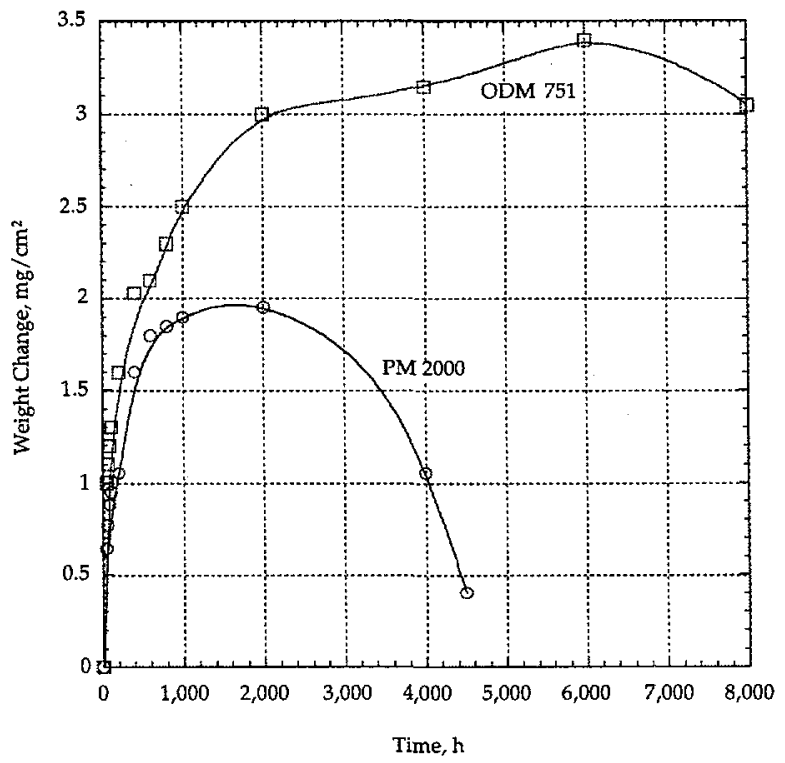

Figure 1. Oxidation kinetics for ODS-FeCrAl- $\mathrm{Y}_{2} \mathrm{O}_{3}$ alloys in air at $1200^{\circ} \mathrm{C}$ cycled to room temperature every $48 \mathrm{hr}$ (after ref. 8). 


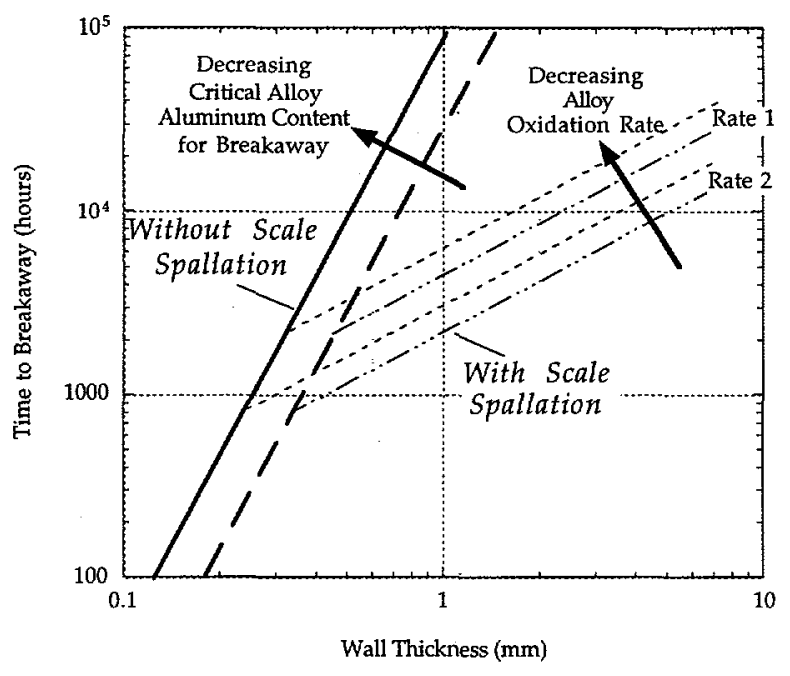

Figure 2. Effects of alloy oxidation rate, oxide spallation, and tube wall thickness on lifetime (time to onset of breakaway oxidation) of ODS-FeCrAl alloys; after Quadakkers and Bongartz, 1994.

for the conventionally-cast alloys. The potential for increasing the creep rupture strength of iron aluminides by ODS processing was demonstrated in the 1960 ' $\mathrm{s}^{21}$ : the incorporation of 12 volume percent of approximately $1 \mu \mathrm{m} \mathrm{Al}_{2} \mathrm{O}_{3}$ to $\mathrm{Fe}-40$ at. percent $\mathrm{Al}$ improved the high-temperature $\left(732^{\circ} \mathrm{C}\right)$ creep strength by a factor of 4 , compared to the dispersion-free, cast alloy.

Overall, there appears to be a niche application for an ODS version of $\mathrm{Fe}_{3} \mathrm{Al}$ in components such as heat exchanger tubes that must operate at very high temperatures, and for which the obvious competition is from ceramic materials. The work in this program is aimed at evaluating this potential.

\section{DISCUSSION OF CURRENT ACTIVITIES}

\section{Preliminary Examination of Available Ferritic ODS Alloys}

A sample of an ODS FeCrAl alloy in the form of a round bar approximately $13 \mathrm{~mm}(0.5$ in.) diameter was obtained from Dour Metal for characterization. Chemical analysis of the alloy showed that it was probably Dour Metal alloy ODM 331, rather than ODM 751 (see Table 1). The grain size of the as-received alloy was determined by metallographic techniques to be approximately $2 \mu \mathrm{m}$, as shown in Fig. 3. Round specimens with a gage diameter of 
approximately $3 \mathrm{~mm}(0.12 \mathrm{in}$.) and a gage length of $12.7 \mathrm{~mm}(0.50 \mathrm{in}$.) were machined from the as-received bar, and subjected to creep-rupture testing in air. The first creep test at $1000^{\circ} \mathrm{C}$ $\left(1832^{\circ} \mathrm{F}\right)$ and $55 \mathrm{MPa}(8 \mathrm{ksi})$ failed in only a few minutes, before sufficient data could be recorded. A subsequent test at $816^{\circ} \mathrm{C}\left(1500^{\circ} \mathrm{F}\right)$ with a stress of $34.5 \mathrm{MPa}(5 \mathrm{ksi})$ produced the data plotted in Fig. 4; the rupture-life was less than 5 hours, with a final elongation of 119.3 percent, and the minimum creep rate (MCR) was approximately $7.75 \% / \mathrm{h}$. This unexpectedly-low creep-rupture resistance was attributed to the small grain size of the as-received material.

In an attempt to produce larger, elongated grains to increase the creep strength, a heat treatment of 25 hours at $1350^{\circ} \mathrm{C}\left(2462^{\circ} \mathrm{F}\right)$ in vacuum was performed on a small sample of the alloy. However, no etchant could be found that would satisfactorily reveal the grain structure resulting from the heat treatment. A drawback of this heat treatment was obvious evaporation of chromium from the outer surface of the specimen, and an observed increase in the size of some of the oxide particles in the matrix. In the absence of a means of measuring the alloy grain size, further testing of this alloy was postponed.

A second series of tests was conducted on a sample of an ODS $\mathrm{Fe}_{3} \mathrm{Al}$-based alloy produced at ORNL (designated FAS-3Y). The nominal composition of this alloy was Fe-28Al$2 \mathrm{Cr}-0.05 \mathrm{~B}$ (at.\%), to which 0.2 cation $\% \mathrm{Y}_{2} \mathrm{O}_{3}$ was added by mechanical alloying (see following

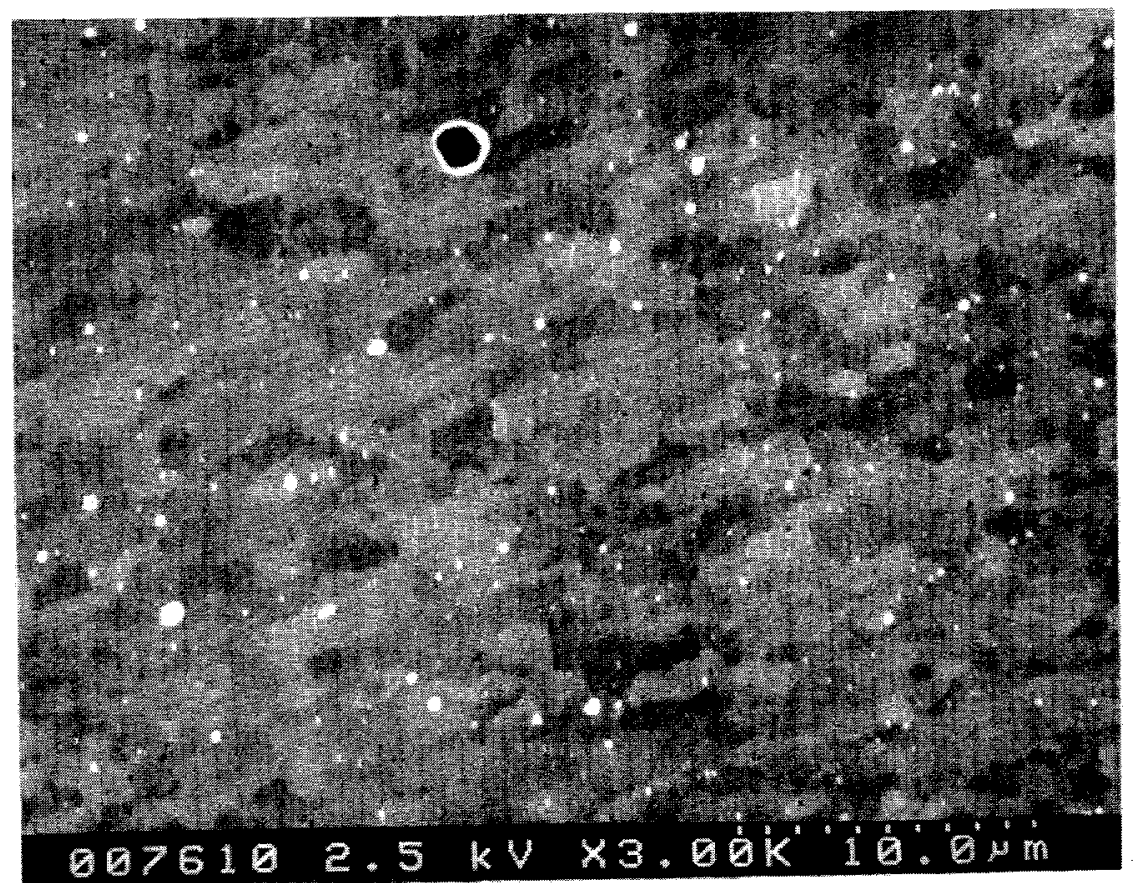

Figure 3. Secondary scanning electron image of a transverse cross section of ODM-331 showing the small grain size and the presence of cavities and oxide particles. 


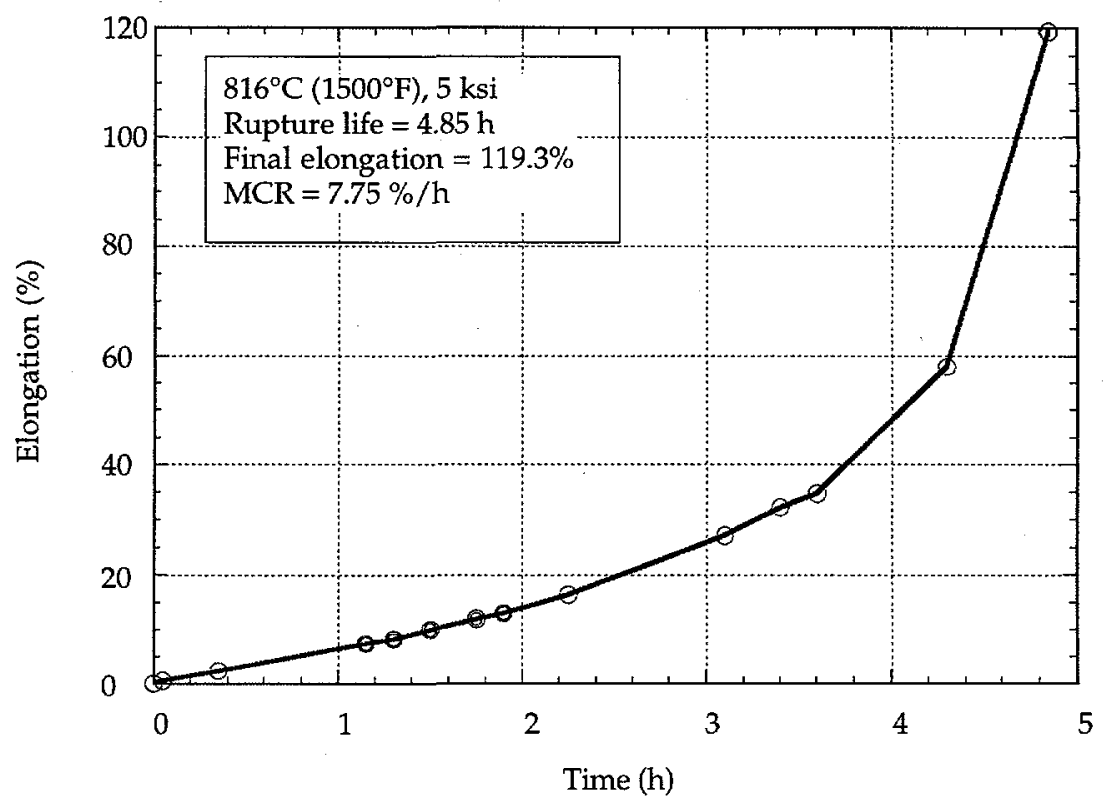

Figure 4. Creep-rupture curve for ODM-331 in the as-received and machined condition, tested at $816^{\circ} \mathrm{C}$ at a stress of $34.5 \mathrm{MPa}(5 \mathrm{ksi})$.

section). Tensile specimens with gage dimensions of $12.7 \times 0.75 \times 3.2 \mathrm{~mm}(0.50 \times 0.030 \times 0.126$ in.) were punched from the as-rolled sheet and heat treated for $8 \mathrm{~h}$ at $1275^{\circ} \mathrm{C}\left(2327^{\circ} \mathrm{F}\right)$ in argon to produce the large-grained banded grain structure, shown in Fig. 5. The results of tensile tests conducted in air at room temperature, 800 , and $1000^{\circ} \mathrm{C}\left(1472\right.$ and $\left.1832^{\circ} \mathrm{F}\right)$ using a strain rate of $3.3 \times 10^{-3} \mathrm{~s}^{-1}$ are shown in Table 2. Typical data for two monolithic ORNL-developed iron aluminide alloys, and for the Dour Metal alloy ODM-751, are included for comparison. At room temperature, the FAS-3Y alloy had a similar tensile strength but a lower ductility compared to the FA-180 alloy, as expected for an oxide-dispersion-strengthened alloy. The FAS-3Y specimen failed in a ductile-dimple manner, with particles at the base of the dimples. Since tensile properties are usually better in iron aluminides with finer-grained microstructures, it is anticipated that the strength of this alloy will improve with heat treatment at a lower temperature. A creeprupture test of this alloy was initiated at $800^{\circ} \mathrm{C}\left(1472^{\circ} \mathrm{F}\right)$ with an initial stress of $34.5 \mathrm{MPa}(5 \mathrm{ksi})$. At this stress, the minimum creep rate appeared to be almost zero. After approximately 240 hours, the stress was increased to $48.3 \mathrm{MPa}$ ( $7 \mathrm{ksi}$ ) and the test was allowed to proceed to rupture. As shown in Fig. 6, rupture occurred suddenly after 383.45 hours, at a specimen elongation of about 3 percent. Another test at $1000^{\circ} \mathrm{C}\left(1832^{\circ} \mathrm{F}\right)$ started at $13.8 \mathrm{MPa}(2 \mathrm{ksi})$. Since there was no discernable creep after 240 hours, the stress was increased to $20.7 \mathrm{MPa}$ (3 ksi), and then to 27.6 $\mathrm{MPa}(4 \mathrm{ksi})$ before failure occurred after 477 hours, with a final eleongation of 6.9 percent. 


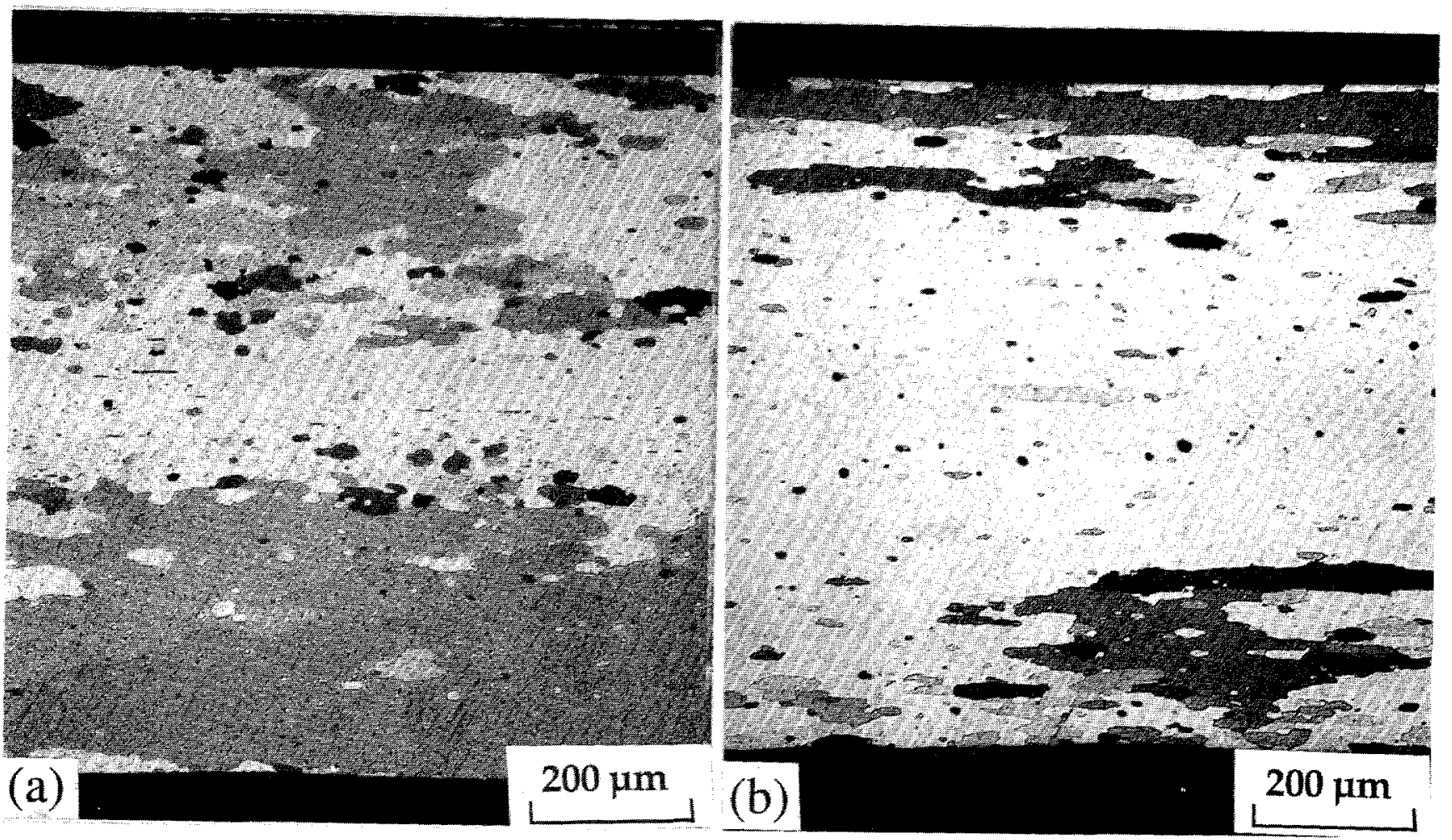

Figure 5. Optical micrographs of FAS-3Y after a heat treatment of $8 \mathrm{~h}$ at $1275^{\circ} \mathrm{C}$ in air; shown is the through-thickness direction (a) parallel to and (b) perpendicular to the rolling direction.

Table 2. Comparison of Tensile Properties of Alloy FAS-3Y With Other Iron-Based Alloys

\begin{tabular}{lrrrrr}
$\quad$ Property & FAS-3Y & FAS & FA-129 & FA-180 & ODM-751 \\
$20^{\circ} \mathrm{C}$ & & & & & \\
YS (MPa) & 643 & 394 & 380 & 620 & \\
UTS (MPa) & 959 & 679 & 900 & 900 & \\
Elongation (\%) & 2 & 9 & 15 & 8 & \\
$800^{\circ} \mathrm{C}$ & & & & & \\
\hline YS (MPa) & 110 & - & & 140 & \\
UTS (MPa) & 120 & & & 148 & \\
Elongation (\%) & 36 & & & 79 & \\
900 & & & & & 160 \\
YS (MPa) & & & & & 10 \\
UTS (MPa) & & & & & \\
Elongation (\%) & & & & 27 & \\
& & & & 137 & \\
$1000^{\circ} \mathrm{C}$ & 43 & & & &
\end{tabular}

FA-129 $=$ Fe-28Al-5Cr-0.5Nb-0.2C (at.\%)

FA-180 $=$ Fe-28Al-5Cr-0.5Nb-0.8Mo-0.025Zr-0.05C-0.005B (at.\%) 


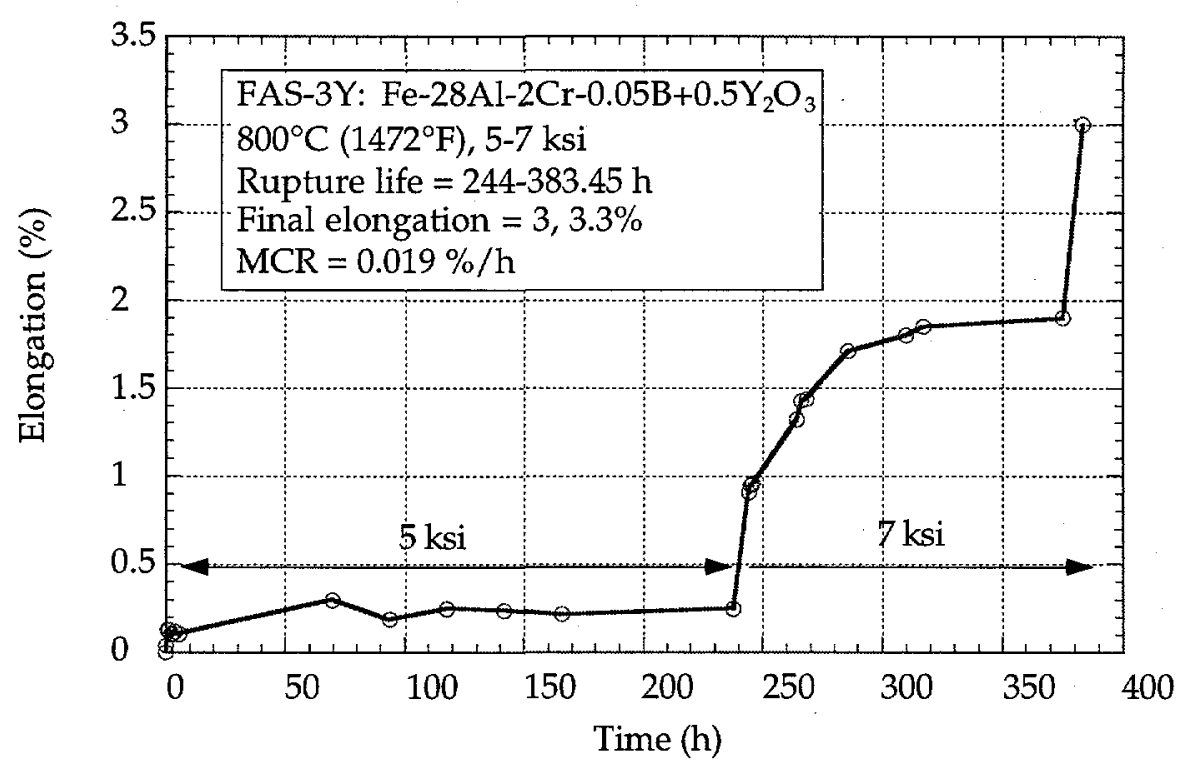

Figure 6. Creep-rupture curve of FAS-3Y heat treated $8 \mathrm{~h}$ at $1275^{\circ} \mathrm{C}$ and tested at $800^{\circ} \mathrm{C}$.

Further creep tests on FAS-3Y will be initiated following the fabrication of a new sample of FAS$3 Y$ material, and the development of thermomechanical processing to produce the desired large, elongated grain structure.

The limited creep-rupture data generated so far on the FAS-3Y material suggests a lower creep resistance than the ODM alloys produced by Dour Metal. However, with the limited number of samples available, the best fabrication and heat treating conditions to produce the desired microstructure for maximum strength have not yet been determined. Plans have been made to obtain a larger sample of this alloy from a commercial vendor.

\section{Development of Mechanical Alloying Parameters for $\mathrm{ODS} \mathrm{Fe}_{3} \mathrm{Al}$}

Initial investigation of mechanical alloying parameters used a Svegvari Type 01STD attritor mill (purchased from Union Process Inc., Akron, Ohio), which has a capacity of 0.75 litres $\left(0.26 \mathrm{ft}^{3}\right)$. This mill was top-loaded (and unloaded) and was fitted with a water-cooled lid and paddle bearing. A typical charge consisted of $150 \mathrm{~g}(0.33 \mathrm{lb})$ of powder, and $1,500 \mathrm{~g}(3.3 \mathrm{lb})$ of stainless steel balls (powder:ball ratio of 1:10). Prealloyed $\mathrm{Fe}_{3} \mathrm{Al}$ (FAS) powder was used, together with reactive metal oxide powder, which was obtained with an average particle size of less than $1 \mu \mathrm{m}$. The FAS powder was obtained from Ametek Corp., and consisted of spherical 
particles having a particle size range of $150 \mu \mathrm{m}$ to $45 \mu \mathrm{m}$, (mesh size $-100 /+325$ ). In use, the loaded and assembled mill was purged with argon for $5 \mathrm{~min}$. prior to the start of milling; a continuous flow of argon was maintained during milling. At the end of a run, the lid was removed and the cooled powder exposed to the ambient laboratory air. The effect of increased milling time was evaluated through examination of the powder size and shape by scanning electron microscopy; the extent of mechanical alloying was determined by light microscopy of metallographically-prepared samples. The mechanical alloying process incorporates the oxide dispersoid into the alloy structure by a repetitive process of welding and smearing of the alloy powder particles on to the mill walls and the balls, followed by detachment of fragments of the powder. A layered structure is developed which contains entrapped particles of the dispersoid; with time, the layers become sufficiently fine that the alloy powder particles attain a homogeneous composition, with a uniform distribution of the dispersoid particles. Figure 7 shows the change in powder particle size as a function of milling time. The most obvious initial effect of milling is flattening of the original spherical particles into discs, which assume irregular



Figure 7. Average particle size of FAS-3Y alloy powder as a function of milling time.

shapes with increased milling time. Further milling results in the transformation from flattened plates to agglomerates of much smaller particles. Once the powder structure observed after 50 hours of milling is attained, further milling produces little alteration in alloy structure or actual particle size. 
The milling parameters chosen for the processing of powder intended for subsequent consolidation and preparation of test specimens were $500 \mathrm{rpm}$ for 48 hours. A larger Svegvari attritor mill, Type $01 \mathrm{HD}$ with a capacity of 1.4 litres $\left(0.49 \mathrm{ft}^{3}\right)$, was used to prepare these materials. The milling conditions were the same as those used in the smaller mill. The amount of powder per batch was increased to $300 \mathrm{~g}(0.66 \mathrm{lb})$ and the larger mill is capable of running 24 hours per day.

A search was made for facilities capable of producing larger batches of mechanicallyalloyed powder, of the order of several kilograms to commercial alloy-production sizes. The following possible sources were identified: INCO, Dour Metal of Belgium; PM HochtemperaturMetall of Germany; AEA Technology of Risley, U. K.; and CRM of Italy. INCO (Huntington, West Virginia) uses ball milling to produce Ni-based ODS-alloys only, and has no current capability that could address the needs of the iron aluminide program; there was also concern about contamination of any mill that was used. INCO International (Hereford, U.K.) produces only Fe-based ODS alloys, but it also has no available mill capacity. Dour Metal has produced tubes of ODS-FeCrAl- $\mathrm{Y}_{2} \mathrm{O}_{3}$, using in-house processing, starting with ball milling and also has made an ODS version of $\mathrm{Fe}-40$ at.\% Al, using alumina as the dispersoid. PM HochtemperaturMetall uses ball milling to produce ODS-FeCrAl- $\mathrm{Y}_{2} \mathrm{O}_{3}$ on a commercial basis, but has not made tubing. AEA, Risley, U.K. has a small-capacity centrifugal mill of new design; this equipment has the potential for better processing control than conventional attritor or ball milling, but is as yet not available in a commercial size. CRM has a small-capacity ball mill, and has been involved with ODS-Fe-40Al. Arrangements currently are being made to work with both Dour Metal and PM Hochtemperatur-Metall to produce several $20 \mathrm{~kg}(44 \mathrm{lb})$ batches of ODS-Fe $3 \mathrm{Al}$ powder from prealloyed FAS powder made by Ametek Corp. The mechanically-alloyed powder will be used by ORNL to optimize the thermomechanical processing required to produce the required grain size and structure, and to measure the properties relevant to the envisioned application.

Effects of a Dispersion of Oxides on the High-Temperature Oxidation Behavior of $\mathrm{Fe}_{3} \mathrm{Al}$

Mechanically-alloyed powders of $\mathrm{Fe}_{3} \mathrm{Al}$ containing additions of the following reactive element oxides: $\mathrm{Y}_{2} \mathrm{O}_{3}\left(0.05,0.2,0.5\right.$ cation \%), $\mathrm{La}_{2} \mathrm{O}_{3}\left(0.05,0.2\right.$ cat.\%), $\mathrm{Al}_{2} \mathrm{O}_{3}$ (0.2 cat.\%), $\mathrm{CeO}_{2}\left(0.2\right.$ cat.\%), $\mathrm{Yb}_{2} \mathrm{O}_{3}(0.2$ cat. \%) were made at ORNL using nitrogen-atomized prealloyed FAS powder in the Svegvari 01HD mill. These powders were canned in mild steel cans, and extruded at $1050^{\circ} \mathrm{C}\left(1922^{\circ} \mathrm{F}\right)$ with a reduction ratio of $12: 1$ to produce rods approximately 25 
$\mathrm{mm}$ (1.0 in.) in diameter. After decanning, disc-shaped specimens were cut from these rods and subjected to oxidation testing with no further heat treatment, that is, with a relatively small alloy grain size. The specimen surfaces were polished with $0.3 \mu \mathrm{m}\left(12 \times 10^{-6} \mathrm{in}\right.$.) alumina and washed before exposure. The details of the test procedures and some of the cyclic oxidation the results are presented elsewhere 22 . Figures 8 and 9 summarize the kinetics of isothermal oxidation in air, and cyclic oxidation in oxygen, respectively, both at $1200^{\circ} \mathrm{C}\left(2192^{\circ} \mathrm{F}\right)$, for the FAS alloy with and without a dispersion of $\mathrm{Y}_{2} \mathrm{O}_{3}$. Ignoring the initial rapid oxidation of the undoped alloy during the

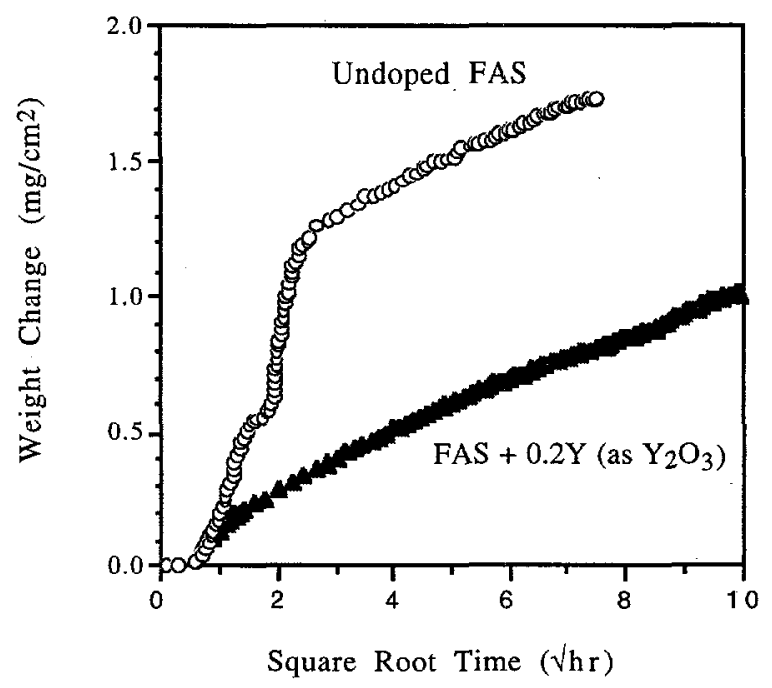

Figure 8. Comparison of the isothermal oxidation kinetics of conventionally-produced and ODS-versions of Alloy FAS (FAS-3Y); $1200^{\circ} \mathrm{C}$ in air.

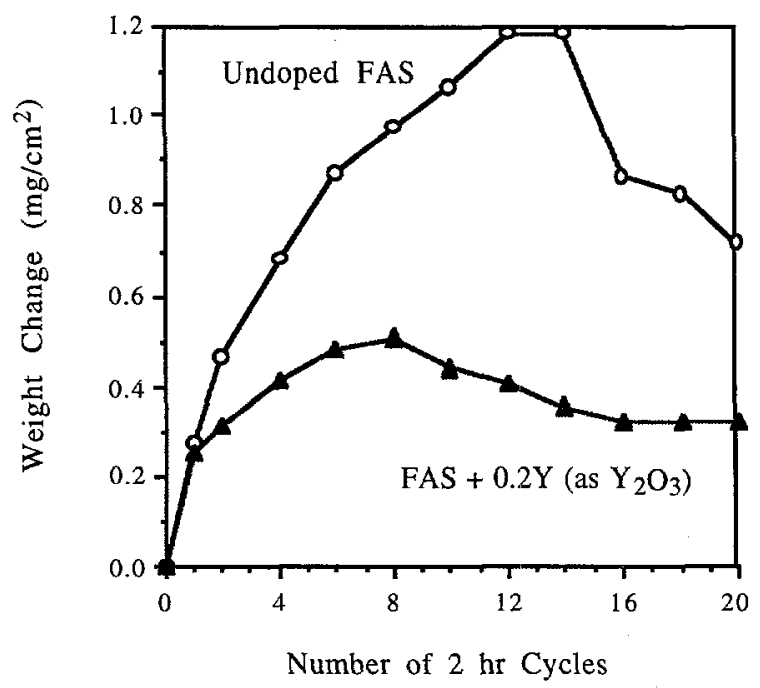

Figure 9. Comparison of the cyclic oxidation kinetics of conventionally-produced and ODSFAS (FAS-3Y); $1200^{\circ} \mathrm{C}$ in oxygen. 
first 4 hours of isothermal exposure, the oxidation rates of the two alloys at longer times appear quite similar; both alloys exhibited oxidation rates that are slightly slower than parabolic, suggesting that the oxide scales become more protective with time. In the cyclic oxidation test, the weight gain of the ODS alloy was very similar to that in the isothermal test up to approximately 16 hours (and obviously slower than that of the undoped alloy), after which it apparently suffered some degree of scale spallation. The reason for the increased weight gain of the undoped alloy in this test was because it suffered from scale spallation at the end of each cycle. The areas over which spallation occurred were extremely small and, since the spalled scale did not fully detach, a net increase in weight was measured up to the 14th cycle, or 28 hours, after which actual scale loss apparently occurred.

Figures 10 and 11 compare the isothermal and cyclic oxidation behavior of the FAS-3Y alloy with a commercially-available ODS-FeCrAl- $\mathrm{Y}_{2} \mathrm{O}_{3}$ alloy, $\mathrm{MA956}$ (see Table 1) at $1200^{\circ} \mathrm{C}$ $\left(2192^{\circ} \mathrm{F}\right)$ in air, and in oxygen, respectively. The kinetics of isothermal oxidation to 100 hours appear essentially the same, as might be expected for alloys that are intended to form a protective alumina scale. Under isothermal conditions, the rate of consumption of aluminum to form the protective scale would be very similar for the two alloys. In the cyclic oxidation test, the weight gain of the MA956 after 40 hours was almost the same as that measured in the isothermal test, indicating no scale spallation. As noted above, the weight gains measured for the FAS-3Y indicated some scale spallation. This is a surprising result, since a dispersion of a reactive element oxide with the appropriate particle size and distribution generally has been found to improve the overall scale adherence on alumina-forming alloys. Such spallation would obviously

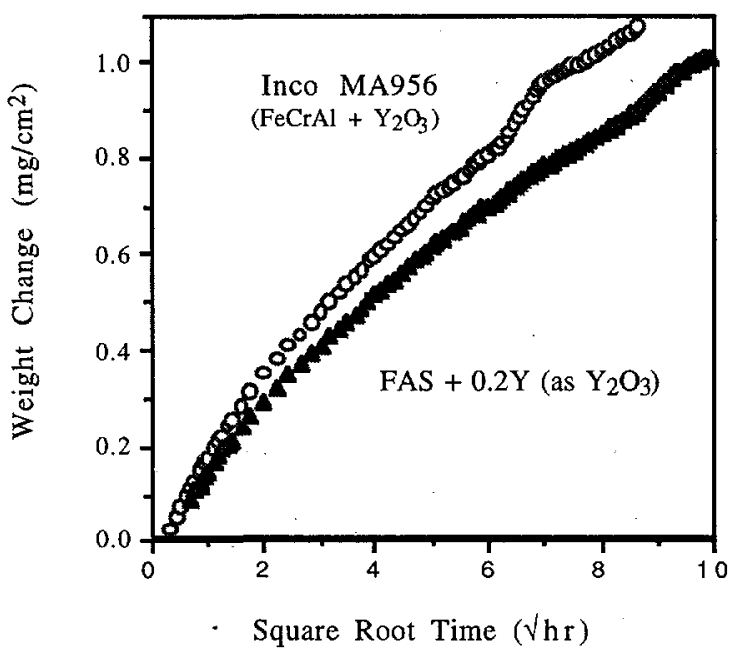

Figure 10. Comparison of the isothermal oxidation kinetics of ODS-FAS (FAS-3Y) with a commercial ODS-FeCrAl- $\mathrm{Y}_{2} \mathrm{O}_{3} ; 1200^{\circ} \mathrm{C}$ in air. 


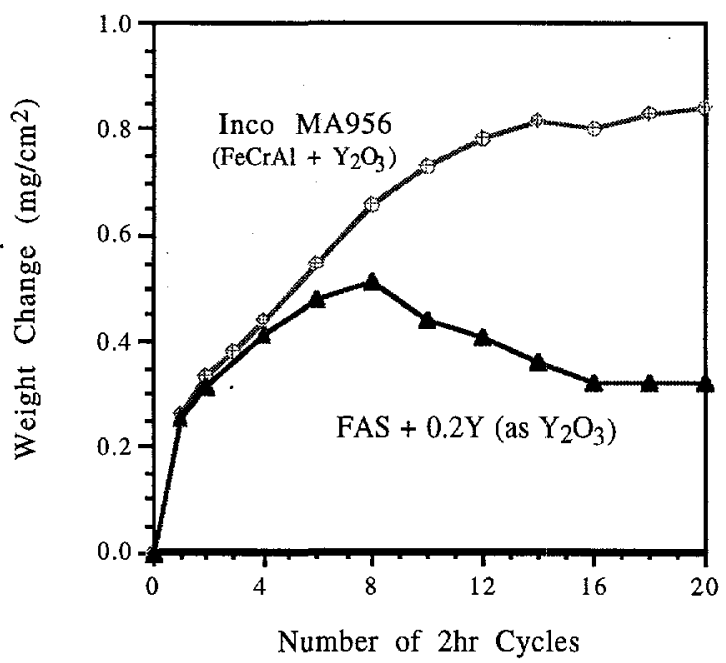

Figure 11. Comparison of cyclic oxidation kinetics of ODS-FAS (FAS-3Y)with a commercial ODS-FeCrAl- $\mathrm{Y}_{2} \mathrm{O}_{3} ; 1200^{\circ} \mathrm{C}$ in oxygen.

increase the rate of depletion of the aluminum reservoir of the FAS-3Y alloy. Although this reservoir is much larger than that in alloy MA956, the rate of spallation must be minimized to maintain the potential service lifetime advantage of FAS-3Y 22 .

There are several possible reasons for the difference in scale spallation behavior between the two alloy types, ranging from inhomogeneity in FAS-3Y to a fundamental difference in the functioning of the reactive element effect in $\mathrm{Fe}_{3} \mathrm{Al}$ compared to $\mathrm{FeCrAl}-\mathrm{Y}_{2} \mathrm{O}_{3}$. The possibility that there are inherent differences in scale spallation behavior between $\mathrm{FeCrAl}$-based and iron aluminide-based alloys ${ }^{20}$, and the effects of different types and levels of reactive element oxides. on the oxidation behavior of $\mathrm{Fe}_{3} \mathrm{Al}$ are the subject of an ongoing study.

\section{SUMMARY AND CONCLUSIONS}

Heat exchangers for cycles which require a working fluid to be heated to temperatures of 1100 $1200^{\circ} \mathrm{C}\left(2012-2192^{\circ} \mathrm{F}\right)$ provide a potential application in which the exceptional high-temperature oxidation and sulfidation resistance of iron aluminides can be exploited. The alternative materials choices for such an application are ODS-FeCrAl-based alloys and ceramics. An ODS-version of $\mathrm{Fe}_{3} \mathrm{Al}$ has the obvious advantage over ceramics that it has metallic characteristics, and is expected to exhibit a significantly longer service life than ODS-FeCrAl alloys. Creep tests with a nonoptimized ODS- $\mathrm{Fe}_{3} \mathrm{Al}$ indicated significantly improved strength compared to non-ODS iron aluminides, but lower creep resistance compared to a commercial ODS-FeCrAl alloy. The 
isothermal oxidation rate of the $\mathrm{ODS}-\mathrm{Fe}_{3} \mathrm{Al}$ was essentially the same as that of a commercial ODS-FeCrAl alloy at $1200^{\circ} \mathrm{C}\left(2192^{\circ} \mathrm{F}\right)$, but there was evidence of inferior resistance to cyclic oxidation. The main issues to be resolved are the ability of optimized ODS processing of $\mathrm{Fe}_{3} \mathrm{Al}$ to achieve an equivalent improvement in high-temperature creep strength to that found with ODS $\mathrm{FeCrAl}$ alloys, and a method for improving the resistance to scale spallation of $\mathrm{Fe}_{3} \mathrm{Al}$.

\section{REFERENCES}

1. F. Starr, A. R. White, and B. Kazimierzak, pp. 1393-1412 in Materials for Advanced Power Engineering, Proc. 5th COST 501 Conf., Liege, Belgium, D. Coutsouradis, et al., eds., Kluwer Academic Pub., Dordrecht (1994).

2. D. Sporer, and O. Lange, ibid, pp. 1469-1488.

3. J. Beckers-Lecomte, D. Coutsouradis, and B. Kazimierzak, ibid, pp. 1489-1498.

4. H. Cama, and T. A. Hughes, ibid, pp. 1497-1506.

5. D. M. Jaeger, and A. R. Jones, ibid, pp. 1507-1514.

6. D. M. Jaeger, and A. R. Jones, ibid, pp. 1515-1522.

7. B. Dubiel, W, Osuch, M. Wrobel, A. Czyrska-Filemonowicz, and P. J. Ennis, ibid, pp. 1523-1532.

8. W. J. Quaddakers, K. Bongartz, F. Schubert, and H. Schuster, ibid, pp. 1533-1542.

9. J. P. Banks, D. D. Gohil, H. E. Evans, D. J. Hall, and S. R. J. Saunders, ibid, pp. 1543-1552.

10. J. Bennett, R. Perkins, J. B. Price, and F. Starr, pp. 1553-1562.

11. G. P. De Gaudenzi, F. Umberti, F. Bregani, and G. P. Toledo, ibid, pp. 1563-1572.

12. R. C. Hurst, M. Rees, and J. D. Parker, ibid, pp. 1573-1582.

13. W. Hessenbruch, Metals and Alloys for Use at High Temperatures, Part 1, Non-Scaling Alloys, J. Springer, Berlin (1940).

14. I. I. Kornilov, Profigrafkniga, Moscow (1945), cited by Setterlund and Prescott, 1961.

15. C. S. Wukusic, The Physical Metallurgy and Oxidation Behavior of Fe-Cr-Al-Y Alloys, Report No. GEMP-414 by General Electric Nuclear Energy Div. on USAEC Contract No. AT (40-1)-2847 (1966).

16. C. Sykes and J. W. Bampfylde, JISI, 130 (II), 389 (1934).

17. R. B. Setterlund and G. R. Prescott, Corrosion 17, 277t-282t (1961).

18. J. F. Nachman and W. J. Buehler, The Fabrication and Properties of 16-ALFENOL (Fe $3 A$ Al)-A Non-Strategic Aluminum-Iron Alloy, U. S. Naval Ordnance Lab. Report No. 2819, (April, 1953).

19. J. F. Nachman and W. J. Buehler, Thermenol ( Fe 3 Al-3Mo), A Non-Strategic Aluminum-Base Alloy for HighTemperature Service, U. S. Naval Ordnance Lab. Report No. 3700, (June 1954).

20. See, for example, J. H. DeVan, P. F. Tortorelli, and M. J. Bennett, pp. 309-320 in Eighth Annual Conf. on Fossil Energy Materials, N. C. Cole and R. R. Judkins (comp.), CONF-9405143, U. S. Department of Energy, August 1994. 21. A. U. Seybolt, Trans. ASM, 포, 861-875 (1966).

22. P. F. Tortorelli, J. H. DeVan, B. A. Pint, and I. G. Wright, paper presented at the Ninth Annual Conference on Fossil Energy Materials, Oak Ridge, TN, May 1995. 


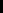




\title{
2.13 MECHANICALLY RELIABLE SCALES AND COATINGS
}

\author{
P. F. Tortorelli and K. B. Alexander \\ Oak Ridge National Laboratory \\ Oak Ridge, Tennessee 37831-6156
}

\section{INTRODUCTION}

In many high-temperature fossil energy systems, corrosion and deleterious environmental effects arising from reactions with reactive gases and condensible products often compromise materials performance and, as a consequence, degrade operating efficiencies. Protection of materials from such reactions is best afforded by the formation of stable surface oxides (either as deposited coatings or thermally grown scales) that are slowly reacting, continuous, dense, and adherent to the substrate. However, the ability of normally brittle ceramic films and coatings to provide such protection has long been problematical, particularly for applications involving numerous or severe high-temperature thermal cycles or very aggressive (for example, sulfidizing) environments. A satisfactory understanding of how scale and coating integrity and adherence are improved by compositional, microstructural, and processing modifications is lacking. Therefore, to address this issue, the present work is intended to define the relationships between substrate characteristics (composition, microstructure, and mechanical behavior) and the structure and protective properties of deposited oxide coatings and/or thermally grown scales. Such information is crucial to the optimization of the chemical, interfacial, and mechanical properties of the protective oxides on high-temperature materials through control of processing and composition and directly supports the development of corrosion-resistant, high-temperature materials for improved energy and environmental control systems.

The work described in this paper is being conducted at Oak Ridge National Laboratory (ORNL) in collaboration with work sponsored by the Department of Energy's Office of Fossil Energy at Argonne National Laboratory (ANL) ${ }^{1}$ and Lawrence Berkeley Laboratory (LBL) ${ }^{2}$ and in concert with directly related activities that are part of the Office of Basic Energy Sciences' Center of Excellence for the Synthesis and Processing of Advanced Materials. These cooperative efforts allow the integration of several advanced and, in' some cases, unique characterization, modeling, and coating/deposition techniques so as to systematically investigate the relationships among corrosion performance, bulk composition, and surface oxide chemistry, structure, adherence, and elastic and plastic properties. However, in order to 
effectively pursue these types of study, it is necessary to first determine the effects of alloy composition, microstructure, surface condition, etc. on high-temperature oxidation behavior and associated scale integrity and spallation tendencies for a particular system. This paper presents initial results in this regard with respect to alumina scales on iron-aluminum alloys using thermal cycling under oxidizing conditions to gauge scale integrity in terms of gravimetric data and microstructural characterization. A similar characterization effort will then be conducted for as-deposited alumina on similar substrates. ${ }^{2}$

This work will ultimately include several model material systems, which are defined as ones that develop, upon oxidation, slowly growing, chemically stable surface oxides that offer the potential for protection of the metal from rapid reaction at high temperatures and show a substantial sensitivity to small additions of certain alloying elements. Alumina on ironaluminum alloys appeared to satisfy these criteria ${ }^{3}$ and this system was chosen as the initial one for study.

\section{EXPERIMENTAL PROCEDURES}

Three iron aluminides were studied. Their compositions and common designations are listed in Table 1. Ingots of these alloys were prepared by arc melting and casting. These were then rolled to a final thickness of between 0.8 and $1.3 \mathrm{~mm}$. Rectangular specimens (typically $12 \times 10 \mathrm{~mm}$ ) were prepared from these sheets. The surface finish was either asground (600 grit, $\mathrm{SiC}$ paper) or polished ( 0.3 or $1 \mu \mathrm{m}$, alumina paste).

Gravimetric measurements under thermal cycling conditions were used to establish overall corrosion behavior at $1000^{\circ} \mathrm{C}$. These cyclic oxidation experiments were conducted in static air by exposing coupons in individual pre-annealed alumina crucibles to a series of (typically) 24-h exposures. At the end of each exposure period, the crucibles were taken from the furnace hot zone into the ambient atmosphere in about $2 \mathrm{~min}$. Both the weight of the specimen, $\mathrm{W}_{\mathrm{s}}$, and that of any spalled scale, $\mathrm{W}_{\mathrm{o}}$ (as collected in the crucible holding the coupon), were measured prior to the start of each experiment and after every thermal cycle. In this way, the total reacted mass due to oxidation, $W_{t}$, where

$$
\mathrm{W}_{\mathrm{t}}=\Delta \mathrm{W}_{\mathrm{s}}+\Delta \mathrm{W}_{\mathrm{o}}
$$

could be measured as a function of oxidation time. Several of the oxidized coupons were examined by scanning electron microscopy (SEM). Two plan-view scale specimens for transmission electron microscopy were prepared from cyclically oxidized FAL and FA129. 
Table 1. Compositions of iron-aluminum alloys used in this study.

\begin{tabular}{cccccc}
\hline \multirow{2}{*}{$\begin{array}{c}\text { Alloy } \\
\text { Designation }\end{array}$} & Al & Cr & Zr & $\begin{array}{c}\text { Concentration } \\
\text { (at. \%) }\end{array}$ \\
\cline { 2 - 6 } & & & & & Other \\
FA186 & 28 & 5 & - & 0.5 & $0.2 \mathrm{C}$ \\
FA129 & 28 & 5 & 0.1 & - & $0.05 \mathrm{~B}$ \\
FAL & 28 & 5 & & & \\
\hline
\end{tabular}

a Balance is Fe.

\section{RESULTS}

Cyclic oxidation results for duplicate FAL specimens with 600 grit surface finishes are shown in Fig. 1. Both $\Delta \mathrm{W}_{\mathrm{S}}$ and $\Delta \mathrm{W}_{\mathrm{o}}$ (filled and open symbols, respectively) are plotted versus time; each data point represents one thermal cycle. Note that the weight of spalled material was usually small. In contrast, significant amounts of spalled material were measured for cyclically oxidized FA129 (Fig. 2) and FA186 (Fig. 3). For both of these alloys, $\Delta W_{0}$ was consistently greater than $\Delta W_{\mathrm{s}}$. Comparing Figs. 2 and 3 with Fig. 1 , and referring to eq. 1 , the total reacted mass due to oxidation $\left(W_{t}\right)$ is therefore significantly greater for FA129 and FA186, as shown in Fig. 4.

Distinct differences in the surface appearance of the respective oxidized ironaluminide alloys were observed. Visual examination revealed a uniformly dark gray product on the FAL and a lighter, powdery scale on the FA129 and (based on substantially fewer observations) FA186. As typified by the representative SEM micrographs in Fig. 5, the oxidized ground FA129 surfaces exhibited areas of bare metal from where the oxide product had completely spalled and fragmented, loosely-adherent pieces of scale. In contrast, the surface oxides grown on ground FAL were nodular and adherent. In this case, oxide appeared to nucleate along grinding marks - see Fig. 5b. These macro- and microscopic differences were observed regardless of exposure time. The surfaces resulting from cyclic oxidation exposures with specimens that first were polished to a finish of either 0.3 or $1.0 \mu \mathrm{m}$ showed scale characteristics somewhat different from those observed for the ground specimens. As shown in Fig. 6, there was some, albeit small, areas of adherent scale on FA129, and a finer, less nodular, adherent surface oxide on FAL. Transmission electron microscopy of plan-view scales formed on FAL and FA129 showed very fine-grained oxides (approximately $200 \mathrm{~nm}$ ) in both cases (Fig. 7). 


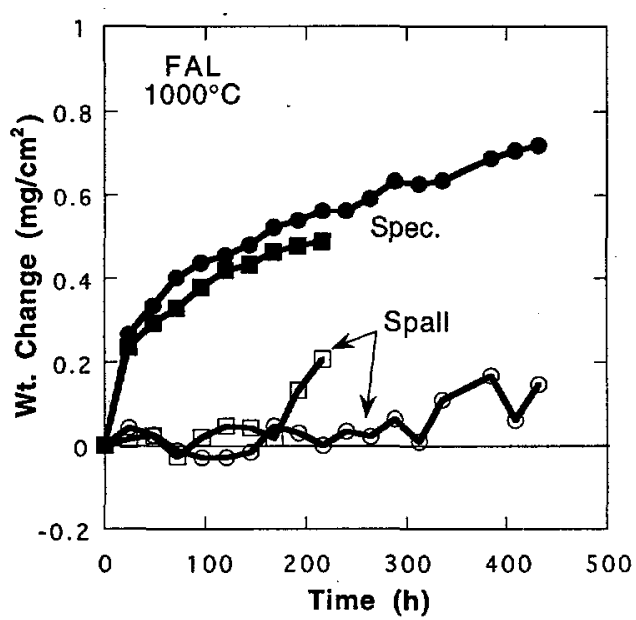

Fig. 1. Weight change versus time for FAL specimens cyclically oxidized in air at $1000^{\circ} \mathrm{C}$. Each point represents one thermal cycle. Closed and open symbols represent weight changes of the specimen and spalled material, respectively. The specimens had a 600 grit surface finish.

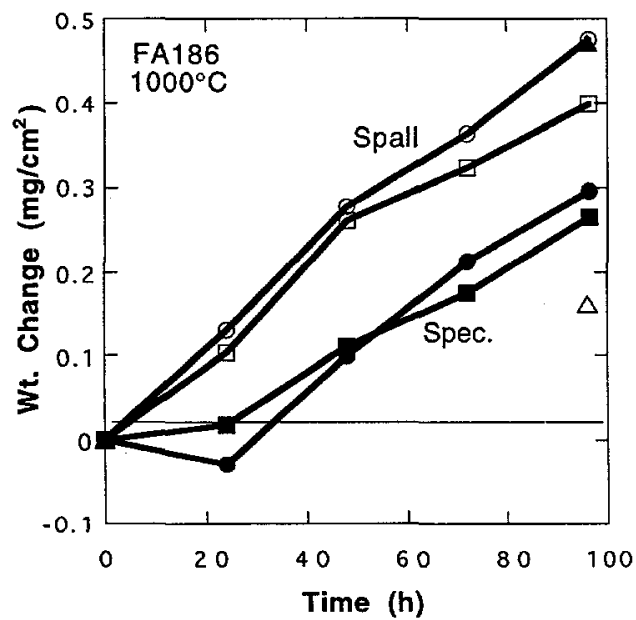

Fig. 3. Weight change versus time for FA186 specimens cyclically oxidized in air at $1000^{\circ} \mathrm{C}$. Each point represents one thermal cycle. The triangles are for a specimen that was exposed for one 96-h cycle. Closed and open symbols represent weights of the specimen and amount of spalled material, respectively. The specimens had a $1 \mu \mathrm{m}$ surface finish. The specimens represented by the circles and triangles were in the asrolled condition prior to exposure. The squares indicated an annealed condition.

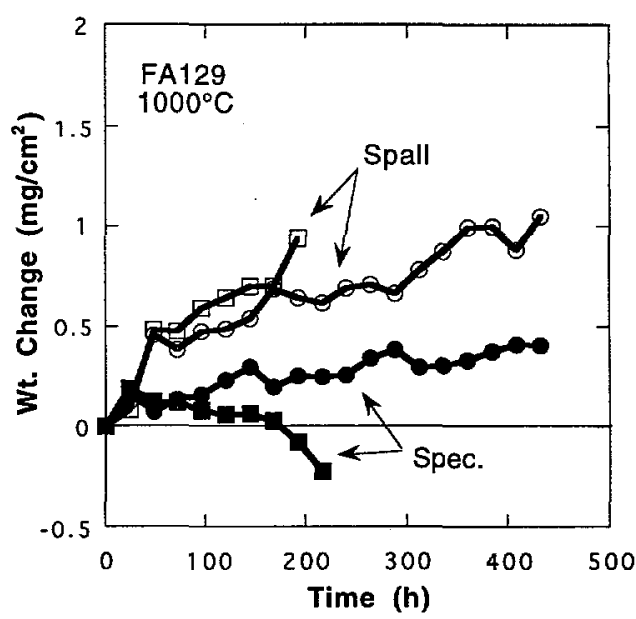

Fig. 2. Weight change versus time for FA129 specimens cyclically oxidized in air at $1000^{\circ} \mathrm{C}$. Each point represents one thermal cycle. Closed and open symbols represent weight changes of the specimen and spalled material, respectively. The specimens had a 600 grit surface finish.

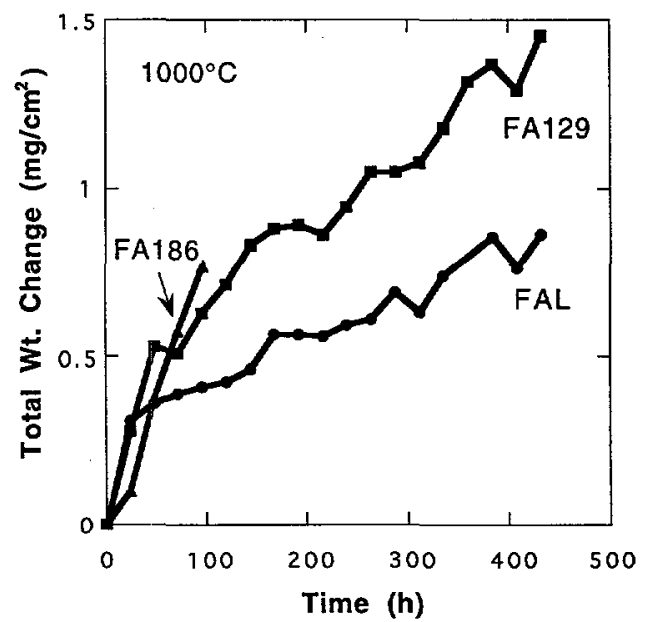

Fig. 4. Total weight change (weight of specimen plus that of spalled material) versus time for FAL, FA129, and FA186 specimens cyclically oxidized in air at $1000^{\circ} \mathrm{C}$. Each point represents one thermal cycle. 

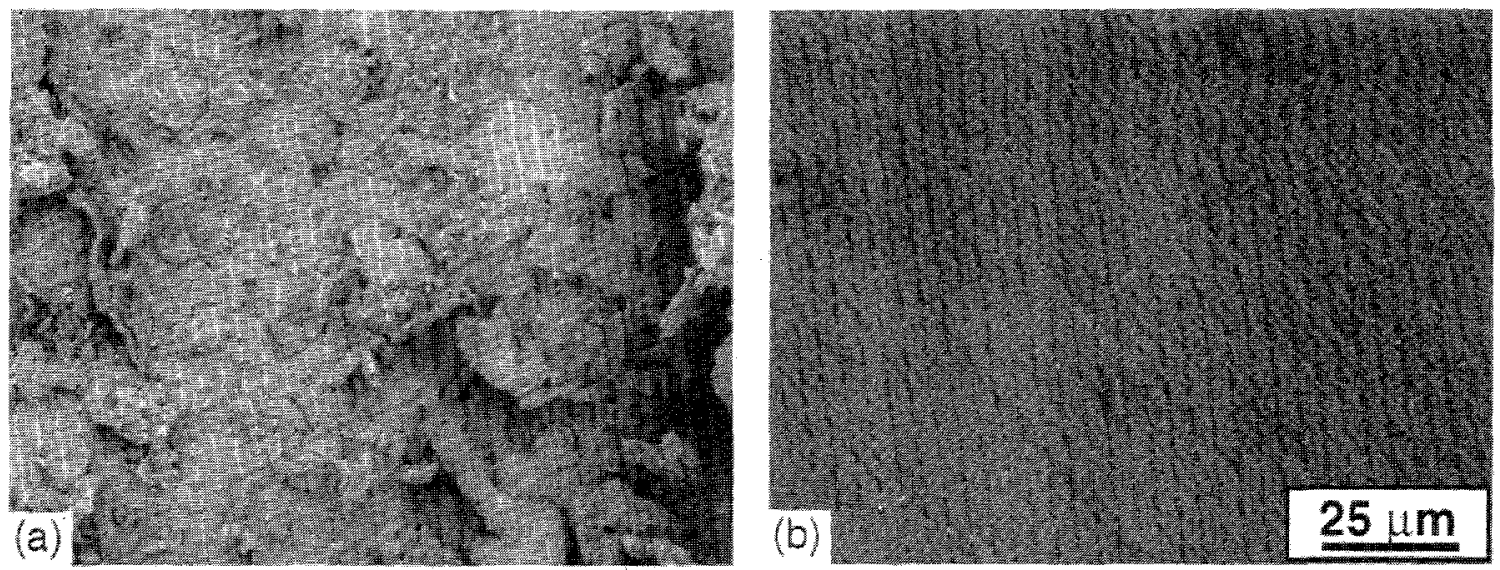

Fig. 5. SEM micrographs of ground ( 600 grit) iron-aluminum alloys that were oxidized for $48 \mathrm{~h}$ (2 24-h cycles) in air at $1000^{\circ} \mathrm{C}$. (a) FA129 (b) FAL.
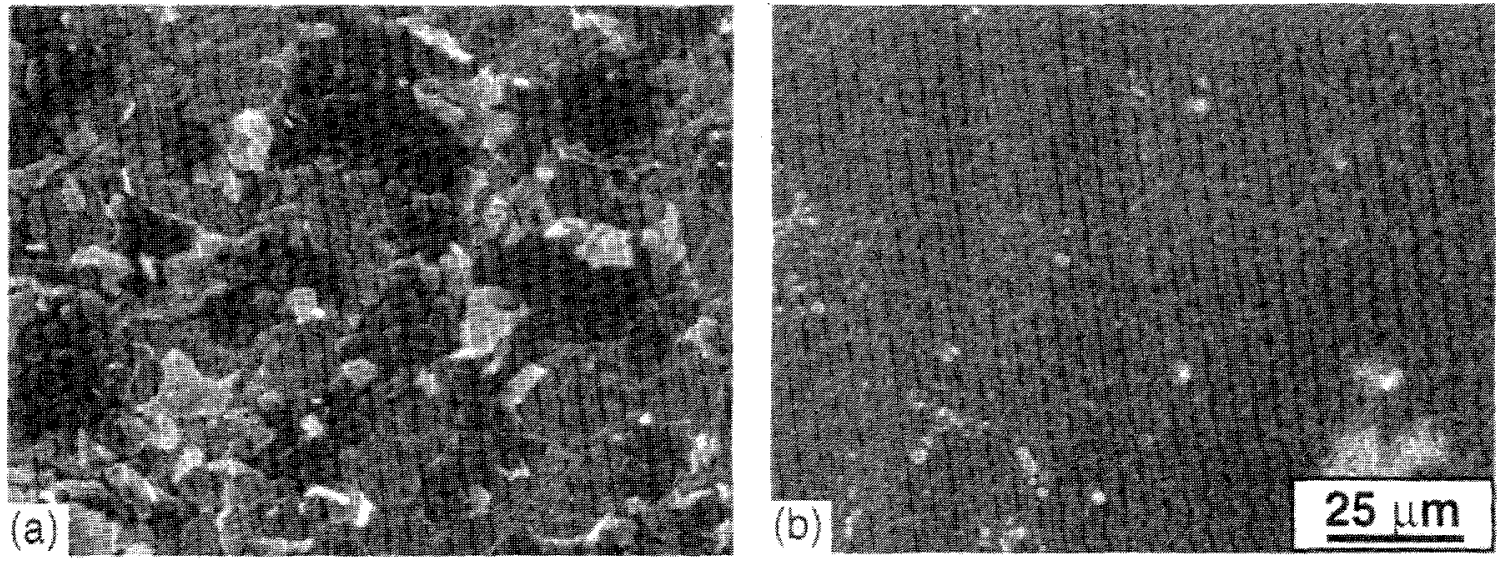

Fig. 6. SEM micrographs of polished $(0.3 \mu \mathrm{m})$ iron-aluminum alloys that were oxidized for $48 \mathrm{~h}$ (2 24-h cycles) in air at $1000^{\circ} \mathrm{C}$. (a) FA129 (b) FAL.
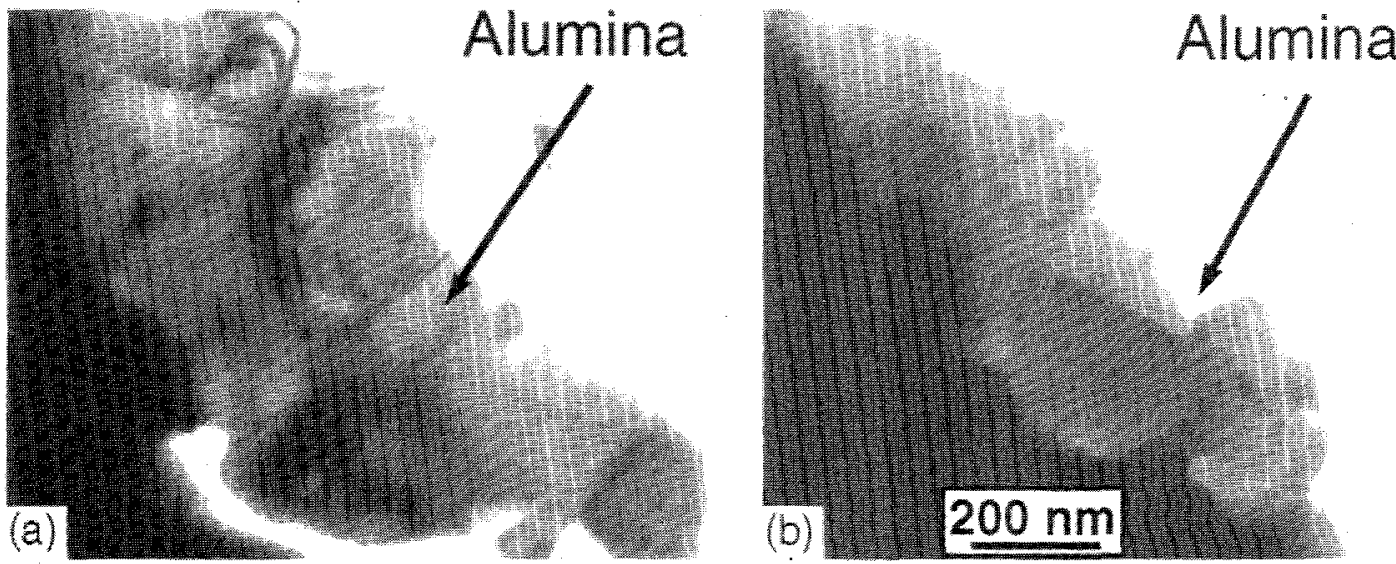

Fig. 7. TEM micrographs of iron-aluminum alloys that were oxidized for $48 \mathrm{~h}(2$ 24-h cycles) in air at 1000$)^{\circ} \mathrm{C}$. (a) FA129 (b) FAL. 
Weight change measurements for polished specimens of FAL are compared to those for ground surfaces in Fig. 8. The ground specimens had slightly higher specimen weight gains, but all the mass changes shown in Fig. 8 are relatively small. With either type of surface finish, the weights of spalled material were substantially less than the respective changes in specimen weight. For FA129, the $\Delta \mathrm{W}_{\mathrm{O}}$ of a polished specimen was less than those of the ground ones (Fig.9), which is consistent with the microscopy results described above. Polished specimens of FA186 were exposed in as-rolled and annealed $\left(1000^{\circ} \mathrm{C}, 1 \mathrm{~h}\right)$ conditions. As shown in Fig. 3 (circles and triangles - as-rolled, squares - annealed), the differences in the gravimetric data due to starting microstructural condition was negligible.

Figure 8 also shows that the gravimetric data for FAL is cycle independent. Two FAL specimens with a $1 \mu \mathrm{m}$ surface finish that were exposed for $96 \mathrm{~h}$ had identical weight changes despite the fact that one had four thermal cycles (square with cross symbols) and the other just one (filled square). In contrast, as shown in Fig. 3, the weight change data for FA186 did depend on the number of cycles - a specimen that was exposed for $96 \mathrm{~h}$ prior to cooling to room temperature (triangles) showed substantially different $\Delta \mathrm{W}_{\mathrm{s}}$ and $\Delta \mathrm{W}_{\mathrm{o}}$ than those measured for specimens of this alloy that underwent four $24-\mathrm{h}$ thermal cycles from $1000^{\circ} \mathrm{C}$ (circles and squares).

\section{DISCUSSION}

Referring to eq. 1, the principal difference between FAL and the other two iron aluminides was in the weight of spalled scale, $\Delta W_{0}$. Alloys FA129 and FA186 showed substantial scale spallation during cooling from the oxidation temperature at the end of most exposure periods. On the other hand, $\mathrm{W}_{\mathrm{O}}$ for FAL was usually negligible (Fig. 1). These results, which were replicated for several specimens of each composition, are consistent with $\mathrm{v}=$ earlier, preliminary studies showing that zirconium had a beneficial effect on the adherence of scales grown on $\mathrm{Fe}_{3} \mathrm{Al}$ alloys at both higher $\left(1300^{\circ} \mathrm{C}\right)^{4}$ and lower $\left(900^{\circ} \mathrm{C}\right)^{5}$ temperatures. Zirconium is known to also have a positive effect on scale adherence in other aluminaforming alloys systems (see, for example, ref. 6), but the mechanism by which it provides a beneficial influence in iron aluminides has not been demonstrated. There is some electron microscopy evidence that zirconium ions accumulate in the alumina scale, ${ }^{7}$ but these observations do not definitively prove any one particular model for the effect of this element on scale adherence. As the initial transmission electron microscopy revealed that the surface oxides on both FAL and FA129 were fairly fine grained (Fig. 7), the effect of zirconium does 


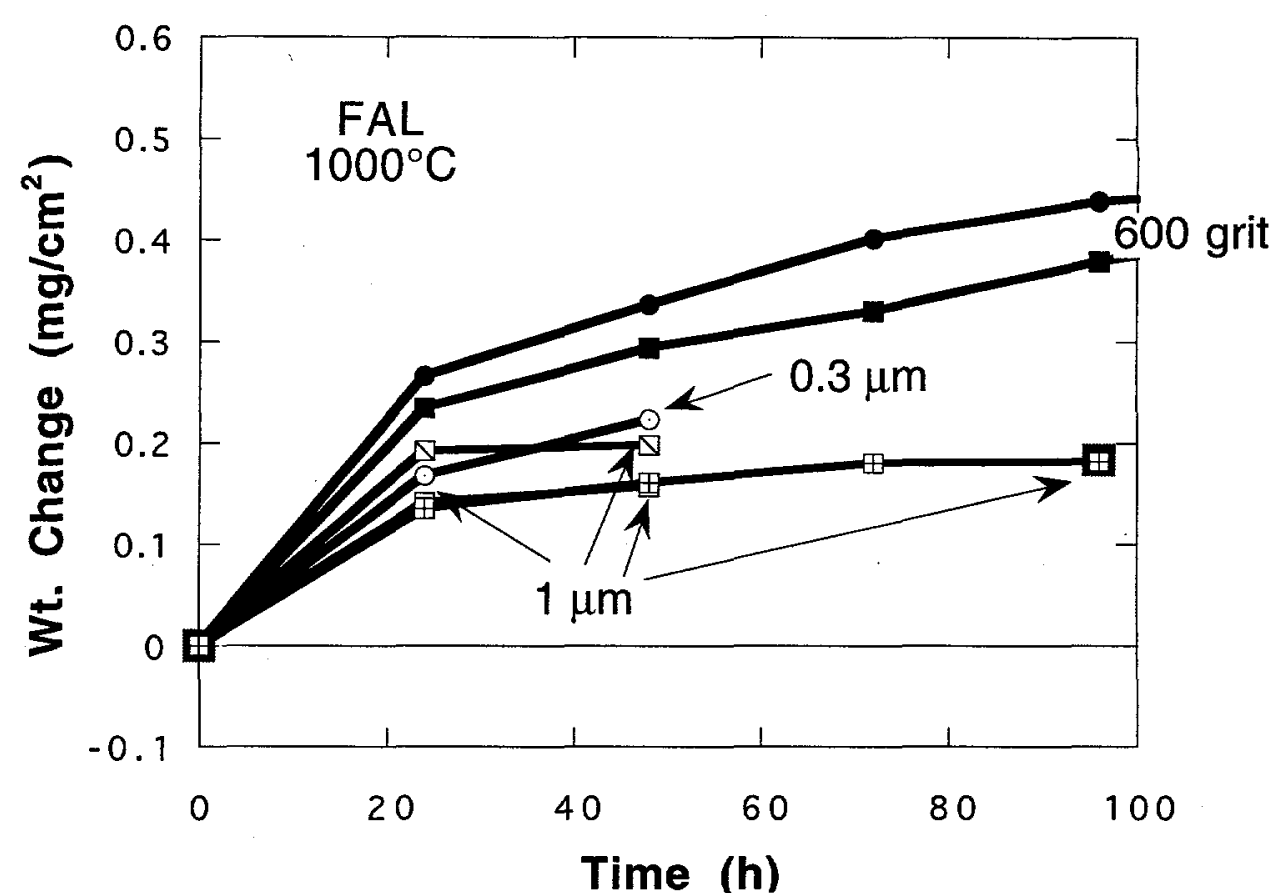

Fig. 8. Specimen weight change versus time for FAL cyclically oxidized in air at $1000^{\circ} \mathrm{C}$. Each point represents one thermal cycle. The specimens had either ground ( 600 grit) or polished $(0.3$ or $1 \mu \mathrm{m})$ starting surfaces as indicated.

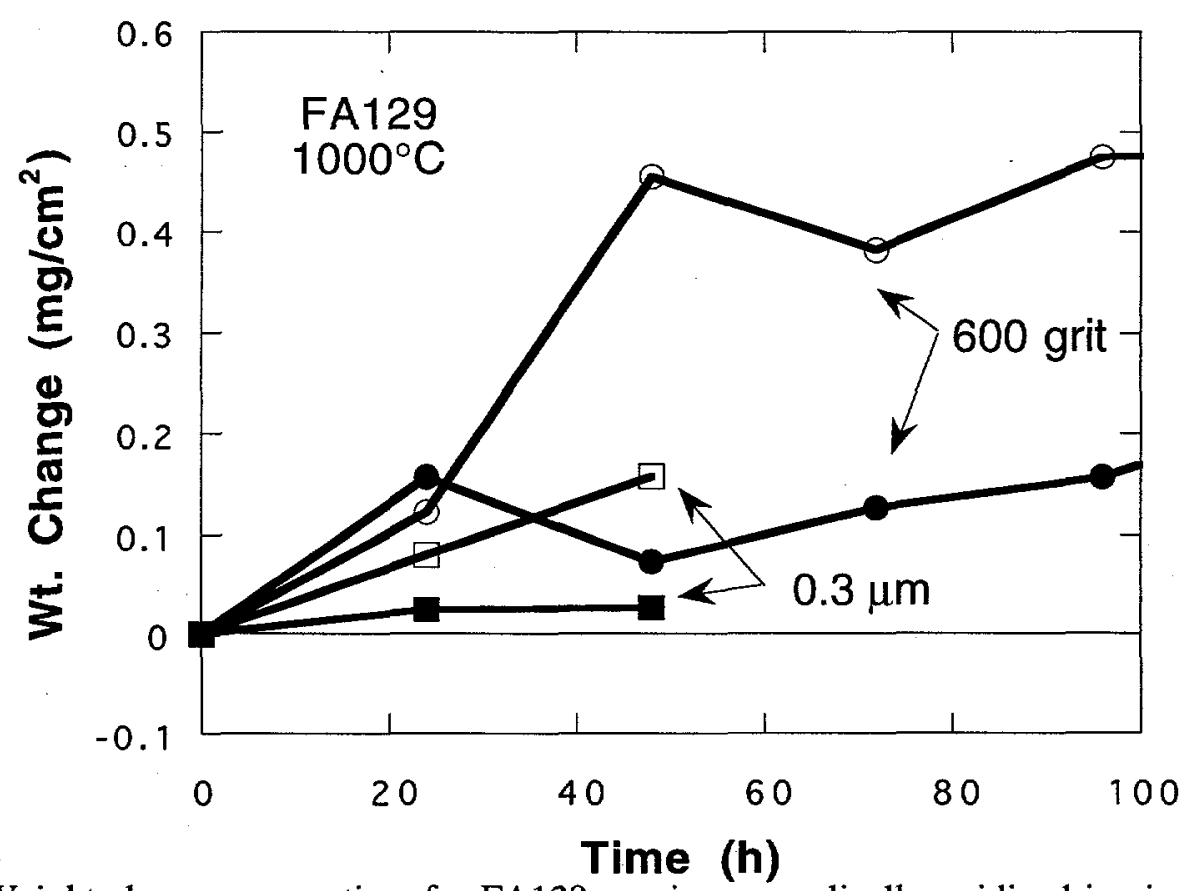

Fig. 9. Weight change versus time for FA129 specimens cyclically oxidized in air at $1000^{\circ} \mathrm{C}$. Each point represents one thermal cycle. The specimens had either ground (600 grit) or polished (0.3) starting surfaces as indicated. Closed and open symbols represent weight changes of the specimen and spalled material, respectively. 
not appear to be due to a major modification of the bulk scale microstructure. However, this result is preliminary; the influence of zirconium on scale and interface characteristics will be investigated in more detail using microscopy and other analytical techniques available at ORNL, ANL and LBL.

For spallation-resistant alloys, there should be little influence of cycle frequency on weight-change measurements unless substantial scale cracking occurs. Therefore, the finding that the measured weight changes of FAL undergoing cyclic oxidation at $1000^{\circ} \mathrm{C}$ are not frequency dependent (Fig. 8) is consistent with the lack of any observations of spallation or visible scale cracking. On the other hand, because of the spallation susceptibilities of FA129 and FA186, the gravimetric results for these alloys do show a dependence on the number of thermal cycles for a given oxidation period (see, for example, Fig. 3). Most of the scale damage is due to thermal cycling; in Fig. $3, \mathrm{~W}_{\mathrm{O}}$ is about the same regardless of whether the first cycle was after 24 or $96 \mathrm{~h}$ of exposure.

As mentioned above, the present work represents the initial stage in defining the fundamental correlations among properties, structure, and mechanical reliability of the surface oxides as they relate to corrosion performance. This first step includes determination of the effects of starting alloy microstructure, composition, and surface finish on hightemperature cyclic oxidation behavior and associated scale integrity and spallation susceptibility. The results of this work are being used to prepare suitable thermally grown oxides on iron-aluminum alloys for examination by a variety of characterization techniques, including analytical electron microscopy, SEM observation of cracking behavior using a bending stage, and nanoindentation (to determine elastic and plastic properties as well as fracture toughness). In this regard, the oxidation results described above have important implications for the use of these alloys as model materials for such a comprehensive study of the microstructure and properties of alumina scales. The use of polished (rather than just ground) surfaces on the specimens of FAL results in a more uniform scale upon oxidation such that these characterization techniques can be facilitated. Furthermore, whereas the scales formed on FA129 with a 600 grit surface finish (Fig. 5a) were wholly unsuitable for such analyses, there appears to be some possibility in obtaining information from the pieces of sound, adherent oxide remaining on polished surfaces of this alloy (see, for example, Fig. 7a). This could be a key part of subsequent study as it may be just as crucial to obtain information from spallation-prone scales (in this case, those formed on FA129 and FA186) as it is for adherent surface oxides (such as those grown on FAL). As such, these results may 
well prove to be an important step in specifying the microstructural, chemical, and mechanical differences of scales exhibiting different degrees of adherence to their alloy substrates.

The present findings on scale damage resulting from cyclic oxidation represent the traditional way of assessing corrosion performance and the mechanical reliability of scales. Because of this, they provide the means of linking oxidation performance of this system with the results forthcoming from use of the characterization techniques listed above. In addition, this study of alumina scales grown on iron-aluminum alloys will form the basis for comparison with results form similar work with as-deposited alumina on the same substrates.

\section{SUMMARY AND CONCLUSIONS}

As a part of the initial effort in defining the fundamental relationships among properties, structure, and mechanical behavior of surface oxides that provide corrosion protection at high temperatures, the integrity of alumina scales formed on iron-aluminum alloys during cyclic oxidation was characterized by gravimetric measurements and microscopy. Specimens with ground or polished surface finishes were prepared from three iron-aluminum compositions. Scales were thermally grown using a series of (typically) $24 \mathrm{~h}$ exposures to air at $1000^{\circ} \mathrm{C}$. Gravimetric data and scanning electron microscopy revealed little scale damage and substantially better adhesion of the alumina grown on the alloy containing zirconium. Thermal cycling caused extensive disruption and spallation of the scales formed on the other two alloys. Transmission electron microscopy showed that scales grown on spallationresistant and spallation-susceptible iron-aluminum alloys were both fine-grained. Use of polished (rather than just ground) specimens resulted in scales that were more amenable to characterization.

\section{ACKNOWLEDGMENTS}

The authors thank M. Howell for experimental support and J. R. DiStefano, B. A. Pint, and I. G. Wright for their thoughtful reviews of the manuscript. This research was sponsored by the Fossil Energy Advanced Research and Technology Development (AR\&TD) Materials Program and the Division of Materials Science, U S. Department of Energy, under contract DE-AC05-84OR21400 with Martin Marietta Energy Systems, Inc. 


\section{REFERENCES}

1. K. Natesan, "Mechanically Reliable Coatings and Scales for High-Temperature Corrosion Resistance," these proceedings.

2. I. W. Brown, "Plasma Synthesis of Alumina Films on Metal and Ceramic Substrates," these proceedings.

3. P. F. Tortorelli and J. H. DeVan, pp. 257-70 in Processing. Properties, and Applications of Iron Aluminides, J. H. Schneibel and M. A. Crimp (eds.), The Minerals, Metals, and Materials Society, Warrendale, PA, 1994.

4. J. H. DeVan, P. F. Tortorelli, and M. J. Bennett, pp. 309-20 in Proc. Eighth Annual Conf. Fossil Energy Materials, N. C. Cole and R. R. Judkins (comp.), CONF-9405143, U. S. Department of Energy, August 1994.

5. J. H. DeVan, P. F. Tortorelli, and U. K. Abdali, "Environmental Effects on Iron Aluminides," pp. 216-226 in Proc. Sixth Annual Conf. Fossil Energy Materials, N. C. Cole and R. R. Judkins (comp.), U. S. Department of Energy, July 1992.

6. J. Doychak, pp. 977-1016 in Intermetallic Compounds: Vol. 1. Principles, J. H. Westbrook and R. L. Fleischer (eds.), John Wiley \& Sons, New York, 1994.

7. J. A. Horton, Oak Ridge National Laboratory, unpublished results. 


\title{
2.14 CARBON FORMATION AND METAL DUSTING IN HOT-GAS CLEANUP SYSTEMS OF COAL GASIFIERS
}

\author{
P. F. Tortorelli, J. H. DeVan, R. R. Judkins, and I. G. Wright
}

\section{INTRODUCTION}

The product gas resulting from the partial oxidation of carboniferous materials in a gasifier consists predominantly of $\mathrm{CO}, \mathrm{CO}_{2}, \mathrm{H}_{2}, \mathrm{H}_{2} \mathrm{O}, \mathrm{CH}_{4}$, and, for air-blown units, $\mathrm{N}_{2}$ in various proportions at temperatures ranging from about 400 to $1000^{\circ} \mathrm{C}\left(750\right.$ to $\left.1830^{\circ} \mathrm{F}\right)$. Depending on the source of the fuel, smaller concentrations of $\mathrm{H}_{2} \mathrm{~S}, \mathrm{COS}$, and $\mathrm{NH}_{3}$ can also be present. The gas phase is typically characterized by high carbon and sulfur, but low oxygen, activities and, consequently, severe degradation of the structural and functional materials used in the gasifier can occur. Therefore, there are numerous concerns about materials performance in coal gasification systems, particularly at the present time when demonstration-scale projects are in or nearing the construction and operation phases. This study focused on the subset of materials degradation phenomena resulting from carbon formation and carburization processes, which are related to potential operating problems in certain gasification components and subsystems. More specifically, it examined the current state of knowledge regarding carbon deposition and a carbon-related degradation phenomenon known as metal dusting as they affect the long-term operation of the gas clean-up equipment downstream of the gasifier and addressed possible means to mitigate the degradation processes. These effects would be primarily associated with the filtering and cooling of coal-derived fuel gases from the gasifier exit temperature to as low as $400^{\circ} \mathrm{C}\left(750^{\circ} \mathrm{C}\right)$. However, some of the considerations are sufficiently general to cover conditions relevant to other parts of gasification systems.

Carbon formation on solid surfaces occurs by deposition from gases where carbon activities $\left(a_{c}\right.$ 's) exceed unity. The presence of a carbon layer can directly affect gasifier performance by restricting gas flow, particularly in the hot gas filter, creating debris (that may be deposited elsewhere in the system or that may cause erosive damage of downstream components), and/or changing the catalytic activity of surfaces. Several sources of information exist on carbon deposition that are relevant to the operation of gasifiers. Blast furnaces, catalytic processes such as Fischer-Tropsch syntheses for hydrocarbon production, and gas-cooled power reactors have all experienced detrimental effects as a result of carbon formation via the decomposition of $\mathrm{CO}$ (Boudouard reaction). In these 
systems, the principal problem is simply the disruption of normal operations caused by the formation and deposition of carbon.

There are also corrosion effects resulting from the formation of carbon layers. A principal one is the phenomenon of metal dusting, ${ }^{1-4}$ which can be a particularly severe form of materials degradation. Metal dusting requires a high carbon activity such carbon deposition occurs and metastable metal carbides form. It is observed at intermediate temperatures (about $400-900^{\circ} \mathrm{C}, 750-1650^{\circ} \mathrm{F}$ ). Susceptible materials disintegrate into a powdery mixture of carbon and fine metal particles ("dusting") that may also include oxides and carbides. These products can be carried away by the flowing gas. Pits and holes on affected surfaces can be observed in addition to general metal wastage. Carbon formation is a necessary but not sufficient condition for metal dusting - a metastable carbide (typically $\mathrm{Fe}_{3} \mathrm{C}$ ) must also form since it is its subsequent decomposition that leads to metal wastage. Metal dusting can be distinguished from carburization, normally seen with hightemperature alloys, which results in the formation of stable carbides on and in the solid exposed to a carbon-containing environment (even at $\mathrm{a}_{\mathrm{c}}<1$ ). The formation of such carbides (normally $\mathrm{M}_{7} \mathrm{C}_{3}, \mathrm{M}_{23} \mathrm{C}_{6}$, or $\mathrm{MC}$, where $\mathrm{M}=\mathrm{Cr}$, $\mathrm{Mo}, \mathrm{Fe}$ ) can lead to loss of ductility, mechanical disintegration, and loss of oxidation resistance (see, for example, refs. 5 - 7). In some cases in the literature, this form of carburization has been reported to precede metal dusting, ${ }^{3}$ but it is distinct from the actual degradation mechanism associated with the latter phenomenon. There are cases where such a distinction has not been made, and "metal dusting" has been used to refer to other carburization effects. The formation of filamentous carbon by disproportionation of carbon monoxide actually exploits the process of metal dusting. ${ }^{8}$

Deterioration of refractories used in coal gasification vessels can occur at temperatures below about $650^{\circ} \mathrm{C}\left(1200^{\circ} \mathrm{F}\right)$ when these materials contain iron or iron alloys (usually castable refractories). An excellent review of this phenomenon, known as CO disintegration, can be found in ref. 9. Carbon deposition from the gas mixture is a necessary step in the process, which then leads to degradation that exhibits many of the same characteristics as metal dusting. Indeed, the basic mechanisms involved in both $\mathrm{CO}$ disintegration of iron-containing refractories and metal dusting appear to be the same, although historically, the studies of the respective phenomena appear to have been conducted independently of each other. 


\section{SUMMARY OF STUDY FINDINGS AND CONCLUSIONS}

1. A review of the literature relating to carbon deposition and metal dusting was conducted. Key sources of information were from research on (1) metal dusting, (2) carbon monoxide disintegration of refractories and (3) carbon deposition, including formation of filamentous carbon. Although the literature in each of these areas proved very useful for this review, cross-referencing among the three appeared incidental, at best.

2. Using SOLGASMIX, 10 the product gas compositions of eight representative gasifier systems were examined with respect to the carbon activity of the gases at temperatures ranging from 480 to $1090^{\circ} \mathrm{C}$ ( 900 to $2000^{\circ} \mathrm{F}$ ) based on three principal chemical reactions:

$$
\begin{gathered}
2 \mathrm{CO}(\mathrm{g})=\mathrm{CO}_{2}(\mathrm{~g})+\mathrm{C}(\mathrm{s}) \\
\mathrm{CO}_{2}(\mathrm{~g})+\mathrm{H}_{2}(\mathrm{~g})=\mathrm{H}_{2} \mathrm{O}(\mathrm{g})+\mathrm{CO}(\mathrm{g}) \\
\mathrm{CH}_{4}(\mathrm{~g})=\mathrm{C}(\mathrm{s})+2 \mathrm{H}_{2}(\mathrm{~g})
\end{gathered}
$$

The composition of the product gas, in particular the $\mathrm{CO}$ concentration from the gasification processes considered, is such that carbon deposition is essentially guaranteed when the gas is cooled after exiting the gasifier. Assuming that all of the gas components are in thermodynamic equilibrium, calculations show that carbon activities greater than unity would result at temperatures below 800 to $870^{\circ} \mathrm{C}\left(1470\right.$ to $\left.1600^{\circ} \mathrm{F}\right)$ in the case of air-blown gasifiers and at considerably higher temperatures in the case of oxygen-blown gasifiers containing greater than $54 \mathrm{vol} \% \mathrm{CO}$.

3. Phase stability calculations indicate that $\mathrm{Fe}_{3} \mathrm{C}$ is only stable under very limited thermodynamic and kinetic conditions and that $\mathrm{FeO}$ and $\mathrm{Fe}_{0.877} \mathrm{~S}$ tend to form instead of the carbide. As formation of $\mathrm{Fe}_{3} \mathrm{C}$ is a necessary step in the metal dusting of steels, there are numerous gasifier environments where this type of carbon-related degradation will not occur, particularly under conditions associated with higher oxygen and sulfur activities. These calculations also indicated that the removal of $\mathrm{H}_{2} \mathrm{~S}$ by a hot-gas cleanup system may have less effect on the formation of $\mathrm{Fe}_{3} \mathrm{C}$ in air-blown gasifier environments, where the iron oxide phase can exist and is unaffected by the removal of sulfur, than in other gasification systems, where iron sulfide provides the only potential barrier to $\mathrm{Fe}_{3} \mathrm{C}$ formation. Therefore, while a thermodynamic driving force for carbon formation on solid surfaces exists at the operating temperatures of the subject gasifier components, the requisite carbide phase necessary for metal dusting is not always formed. 
4. In current gasification systems, significant problems resulting from carbon deposition have not been experienced, or, if they have, they have not been reported. The main factors militating against carbon deposition and/or metal dusting in these systems are thought to be:

i. The presence of sufficient sulfur in the raw gas leaving the gasifier to inhibit the relevant reactions by poisoning catalytic surfaces.

ii. The rapid cooling in the quench systems, which effectively fixes the gas composition.

iii. The gas compositions being outside the range of thermodynamic stability of $\mathrm{Fe}_{3} \mathrm{C}$.

5. The adoption of hot-gas desulfurization strategies will probably increase the significance of the carbon-related degradation, since $\mathrm{H}_{2} \mathrm{~S}$ will then be removed in a temperature regime where carbon deposition and metal dusting are possible.

6. Alloy selection can be an important consideration relative to process performance and economics. With respect to prevention of carbon deposition and metal dusting, alloy selection is reduced to two general alternatives: carbon or low-alloy steels, provided certain criteria are met (see no. 7 below), and higher alloyed steels or heat-resistant alloys. As stated in (2) above, temperatures prevailing in gasifiers employing hot-gas cleanup essentially guarantee conditions that will support carbon deposition on carbon and lowalloy steels. Metal dusting is then possible when a metastable carbide (normally $\mathrm{Fe}_{3} \mathrm{C}$ ) can form and then decompose.

7. The use of carbon- and/or low-alloy steels will dictate that the process gas composition be such that $\mathrm{Fe}_{3} \mathrm{C}$ cannot form if the possibility of metal dusting is to be eliminated. Alternatively, process modifications could include the re-introduction of hydrogen sulfide (to poison the carbon deposition reaction or to form iron sulfide at the expense of $\left.\mathrm{Fe}_{3} \mathrm{C}\right)$, cooling the gas to perhaps as low as $400^{\circ} \mathrm{C}\left(750^{\circ} \mathrm{F}\right)$, and/or steam injection. However, sulfidation may then be a problem.

8. If higher alloy steels (those that will form and maintain a protective chromia film on the surface) are used, a hydrogen sulfide-free gas (or a gas with very low hydrogen sulfide content at higher temperatures) may be processed without concern about carbon deposition and metal dusting.

9. It is considered prudent to conduct some testing, preferably under prototypical coal gasification conditions, to experimentally validate the thermodynamic calculations and assumptions about kinetic limitations that are key to developing a predictive capability with 
respect to carbon formation and metal dusting and to examine the potential of aluminaforming alloys for service in environments that can cause carbon-related degradation.

\section{ACKNOWLEDGMENTS}

This research was sponsored by the Morgantown Energy Technology Center (METC) and the Fossil Energy Advanced Research and Technology Development (AR\&TD) Materials Program, U S. Department of Energy, under contract DE-AC05-84OR21400 with Martin Marietta Energy Systems, Inc. The authors wish to thank Justin Beeson and Thomas Grindley of METC for their help in defining the problems addressed by this study and for many useful technical comments regarding the analyses and conclusions.

\section{REFERENCES} (1966).

1. R. F. Hochman and J. H. Burson III, API Division of Refining Proc. 46, 331

2. R. F. Hochman, p. 715 in Properties of High Temperature Alloys, Z. A. Foroulis and F. S. Pettit (eds.), The Electrochemical Society, Princeton, NJ, 1976.

3. J. C. Nava Paz and H. J. Grabke, Oxid. Met. 39, 437 (1993).

4. H. J. Grabke, R. Krajak, and J. C. Nava Paz, Corros. Sci., 35, 1141 (1993).

5. R. A. Perkins, p. 617 in Behaviour of High-Temperature Alloys in Aggressive Environments, I. Kirman, J. B. Marriott, M. Merz, P. R. Sahm, and D. P. Whittle (eds.), The Metals Society, London, 1980.

6. J. K. Stanley, p. 143 in High Temp. Gas-Met. React. Mixed Environ.. S. A. Jansson and Z. A. Foroulis (eds.), AIME, New York, 1973.

7. H. J. Grabke and I. Wolf, Mater. Sci. Eng. 87, 23 (1987).

8. R. T. K. Baker, D. J. C. Yates, and J. A. Dumesic, p. 1-22 in Coke Formation on Metal Surfaces, L. F. Albright and R. T. K. Baker (eds.), American Chemical Society, 1982.

9. J. J. Brown, Jr., Virginia Polytechnic Institute and State University report, VPI/ME-13702-12, July 1984 1977.

10. T. M. Besmann, Oak Ridge National Laboratory report, ORNL/TM-5775, April 



\title{
2.15 MATERIALS SUPPORT FOR HITAF
}

\author{
K. Breder and V. J. Tennery
}

\section{INTRODUCTION}

The purpose of this project is to compare structural ceramic materials proposed for use in the air heater of a coal fired high temperature advanced furnace (HITAF) for power generation. This work will provide necessary initial structural ceramic parameters for design of a prototype system. Two teams are currently funded by Pittsburgh Energy Technology Center (PETC) under the Combustion 2000, Phase 1, program to develop such a system. One team is led by the United Technologies Research Center, and the other team is led by Foster Wheeler Development Corporation ${ }^{1,2}$ Proposals for Phase 2 and 3 of the Combustion 2000 are currently under evaluation by DOE. Phase 2 is engineering development and testing, consisting of subsystem and materials testing, and Phase 3 consists of the detailed design, construction, operation, and evaluation of a prototype plant. Phase 1 of the work performed here consisted of evaluation of the mechanical properties of three structural ceramics at high temperatures in air and a preliminary evaluation of mechanical properties of these structural ceramics after exposure to coal ash. This work is now completed and the results will serve as baseline data for further work. ${ }^{3}$ In Phase 2 of the present work and initial screening of candidate structural ceramics with respect to their creep properties in air at selected temperatures will be performed, and temperatures above which creep may become a design problem will be identified. Tubes and tube sections of the candidate ceramics will then be exposed to a combination of mechanical loads, coal ash exposure and high temperature, and corrosion behavior, mechanisms and post exposure mechanical properties will be evaluated. 


\section{DISCUSSION OF CURRENT ACTIVITIES}

\section{Materials}

Two of the materials studied in Phase I of this project were used in a set of flexural creep measurements. These were NT230 siliconized silicon carbide from Saint Gobain Norton company and Lanxide DIMOX $\mathrm{SiC}_{\mathbb{P}} / \mathrm{Al}_{2} \mathrm{O}_{3}$ from DuPont Lanxide Composites Inc. Both these ceramics had exhibited some creep during the high temperature dynamic fatigue measurements. The third material tested in Phase 1 $(\beta-\mathrm{SiC})$ exhibited no creep at the temperatures under consideration. NT230 SiC is siliconized silicon carbide and contains free silicon metal $(8 \mathrm{vol} \%)$ and some residual porosity. The $\mathrm{SiC}_{\mathrm{p}} / \mathrm{Al}_{2} \mathrm{O}_{3}$ which is manufactured by the Lanxide Direct Oxidation process (DIMOX) contains 48 vol\% $\mathrm{SiC}_{\mathrm{p}}, 38$ vol\% $\mathrm{Al}_{2} \mathrm{O}_{3}$ and 13 vol\% Al-alloy, and some residual porosity. The SiC ceramics were tested as machined while the Lanxide DIMOX was reoxidized by the manufacturer after machining.

Ceramic tubes for the coal ash exposure experiments have been ordered, and delivery is expected shortly. They are NT230 SiSiC from Saint Gobain Norton and Lanxide DIMOX $\mathrm{SiC}_{\mathrm{p}} / \mathrm{Al}_{2} \mathrm{O}_{3}$ from DuPont Lanxide Composites Inc. as described above, $\beta$-SiC from Coors Ceramics Co., and Hexoloy sintered $\alpha-S i C$ from Carborundum Co. The tubes are nominally $50 \mathrm{~mm}\left(2^{\prime \prime}\right)$ OD and $38 \mathrm{~mm}$ (1.5") ID and are $305 \mathrm{~mm}$ (12") long. A thorough description of the materials have been given previously. 3

\section{Experimental procedure}

Flexure creep tests were carried out in four-point bending, $40 \mathrm{~mm}$ outer and $20 \mathrm{~mm}$ inner span with specimens dimensions $4 \mathrm{~mm}$ by $3 \mathrm{~mm}$ by $50 \mathrm{~mm}$. The fixtures were $\mathrm{SiC}$ fixtures with pins that were free to rotate. The experiments were carried out in the flexure test system (FTS) which is a hydraulic system with SiC push rods in load control. The fixtures and part of the push rods were entirely contained in the furnace which was heated by molybdenum disilicide elements and could be kept at temperatures up to $1600^{\circ} \mathrm{C}$ for more than 1000 hours. Two types of tests have been done. Static tests at a fixed load for 300 hours and stepped loads of $100 \mathrm{~h}$ duration each. The static tests were performed at $1400^{\circ} \mathrm{C}$, i.e. the temperature at which creep was observed in the 
dynamic fatigue experiments, and the loads were chosen such as to correspond to $25 \%$ and $70 \%$ of the fast fracture strength at that particular temperature. The stepped tests were carried out at 1200,1300 and $1400^{\circ} \mathrm{C}$ at loads corresponding to stress levels of $50 \mathrm{MPa}, 100 \mathrm{MPa}, 150 \mathrm{MPa}$ and so on up to $250 \mathrm{MPa}$ (i.e. $500 \mathrm{~h}$ ) or to failure. For these tests two of the three stations were loaded with fixture and specimens while the third station was loaded with a dummy fixture only.

An automatic data acquisition system records the time, temperature, load and deflection at specified intervals. The deflection is measured by the use of a linear variable differential transducer (LVDT'), and the movement of the loading pins are measured. The dummy fixture is used to subtract the deflection of the fixture and push rods from the data, and also to monitor any irregular movements due to temperature changes or other effects. The resulting raw data are files consisting of load, LVDT reading (in mil) and temperature versus time. Additional creep tests were carried out in a similar system, but in this case the flexure test system was equipped with a three probe extensiometer which uses a super linear variable capacitor (SLVC), so that the creep deformation of the center of the specimen relative to the loading points could be monitored directly. In this way additional confirmations of the measured creep rates was obtained at several temperatures and stress levels.

As a first approximation and for comparison between the materials and with previous experiments ( $\mathrm{Lin}$ and $\mathrm{Becher} \mathrm{Al}_{2} \mathrm{O}_{3} / \mathrm{SiC}$ whisker) ${ }^{4,5}$ the analysis by Hollenberg et al. ${ }^{6}$ was used. The constitutive law (for creep) is expressed as:

$$
\varepsilon(\mathrm{t}, \sigma)=\sigma^{\mathrm{n}} \mathrm{J}(\mathrm{t})
$$

where is $\varepsilon(t, \sigma)$ the time dependent creep, $\sigma$ is the applied stress, $n$ the creep exponent, and $J(t)$ the creep compliance. For a beam in bending Hollenberg et al. show that if the creep exponent $\mathrm{n}$ is the same in tension and compression the following relation between the outer fiber strain and the load-point deflection $\mathrm{y}_{\mathrm{L}}$ is obtained:

$$
\varepsilon=\frac{2 h(n+2)}{\left(L_{O}-L_{i}\right)\left[L_{O}+L_{i}(n+1)\right]} y_{L}
$$

where $L_{O}$ and $L_{i}$ are outer and inner span respectively, $h$ is the specimen height, $n$ is the creep exponent and yL the load point deflection.

The outer fiber stress is the given by: 


$$
\sigma_{\max }=\frac{3\left(\mathrm{~L}_{0}-\mathrm{L}_{\mathrm{i}}\right) \mathrm{P}(2 \mathrm{n}+1)}{2 \mathrm{~b} \mathrm{~h}^{3} 3 \mathrm{n}}
$$

where in addition to the descriptions given above, $\sigma_{\max }$ is the stress, $\mathrm{P}$ is applied load, and $\mathrm{b}$ the width of the specimen. Further, according to Hollenberg the following relationship between the load point deflection and load exists:

$$
\log \frac{d y_{L}}{d t}=n \log P+C
$$

where the constant $\mathrm{C}$ is a function of the specimen dimensions, the fixture dimensions, the creep exponent and the creep compliance. Hence, by plotting the load point deflection rate $\left(\mathrm{dY} \mathrm{Y}_{\mathrm{L}} / \mathrm{dt}\right.$ ) vs the applied load $\mathrm{P}$ on a $\log$-log plot the plot should be a straight line with slope equal to $\mathrm{n}$.

Three types of coal ash have been obtained from the University of North Dakota Energy and Environmental Research Center (UNDEERC). These have been received by the UNDEERC from three different power plants, and chemical analysis and viscosity versus temperature data have been measured by UNDEERC. A description of the three coal ashes follow.

\section{ILLINOIS No. 6 - Coffeen}

This coal ash came from coal burned at the Central Illinois Public Service Coffeen Plant. The coal was produced from a low sulfur spur of the main seam called the East Hornsby seam. The coal is low in sulfur because it contains less pyrite $\left(\mathrm{FeS}_{2}\right)$ than normal, and the resulting reduced Iron level leads to a high viscosity for the slag. Therefore, $1.5 \%$ limestone was added by the power plant to lower the viscosity. The resulting slag is a low Fe, high Ca Illinois No. 6 with the same viscosity as a "normal" Illinois No. 6.

\section{Powder River Basin, Rochelle}

This coal came from coal burned at the Northern States Power Riverside Plant, and was produced from the Rochelle mine, Wyoming. Approximately $3 \%$ petroleum coke was added at the power plant which resulted in a high Vanadium content. Since it contains burned coke (C), bubbling may occur during the test and later cause a mess, therefore the slag will be heated to $800^{\circ} \mathrm{C}$ for $0.5 \mathrm{~h}$, stirred, and heated for another $0.5 \mathrm{~h}$ 
in order to burn off the coke before the exposure experiments. The slag may after this appear to have clumps, but will in spite of that not be sieved.

\section{ILLINOIS No.6. - Baldwin}

This slag came from coal burned at the Illinois Power Company, Baldwin Plant. It is a mixture of Illinois No. 6 and Illinois No. 5 from the Peabody Coal Company Marissa mine and from the Arch Mineral company Captain mine. Some minerals, especially $\mathrm{FeS}_{2}$ were removed before shipping from the mine, something that is standard practice, an it contains no additives. The resulting slag is a typical Illinois No. 6 with less $\mathrm{Ca}$ and more Fe than the batch from the Coffeen Plant.

All the slag samples received at ORNL were split from the main barrel into smaller samples according to ASTM.

The coal ash exposure tests will be carried out at $1090^{\circ} \mathrm{C}\left(2000^{\circ} \mathrm{F}\right), 1260^{\circ} \mathrm{C}$ $\left(2300^{\circ} \mathrm{F}\right)$ and $1430^{\circ} \mathrm{C}\left(2600^{\circ} \mathrm{F}\right)$ in air. Two sets of experiments will be performed. One set in which tube sections of about $300 \mathrm{~mm}$ will be covered with the coal ash and exposed in a furnace for up to $500 \mathrm{~h}$. Additional ash will be introduced during the test and a such that a minimum of $5 \mathrm{~mm}$ coal slag layer will be achieved. After exposure, the tubes will be examined, cut into $10 \mathrm{~mm}$ wide C-rings, and the remaining strength will be measured by performing a fracture test at the same temperature as the exposure temperature. After strength measurements fracture surfaces will be examined and the slag/ceramic interfaces will be examined using scanning electron microscope (SEM) and a scanning electron microprobe. The second set of tests will be carried out in a modified version of the flexure test system. C-rings will be loaded to a given stress level, heated to the test temperature, and the coal slag will be introduced into the furnace in such a manner that the tensile surfaces (outer) of the C-rings will be exposed to the coal slag. Slag will be re-introduced at given intervals throughout the test to ensure that the corrosive species will be in contact with the specimens for the entire test time.

The University of North Dakota Energy and Environmental Research Center is a member of the United Technologies team in the development of a Combustion 2000 HiPPS concept. As part of that effort, a 100 hour pilot-scale slagging combustion test of some alloy heat exchangers and some extremely corrosion resistant refractories will be performed. The test will be performed in the UNDEERC $750000 \mathrm{Btu} / \mathrm{hr}$ combustor in mid-May 1995, while firing the same Illinois No. 6 coal that was burned at the Illinois Power Baldwin plant to produce the slag which will be used in part of the laboratory experiments. United Technologies has given permission to include samples 
of materials of interest to others involved in DOE-funded corrosion research. The specimens will be mounted in the wall of the furnace by cutting a hole in the refractory liner several inches deep, inserting the sample in the hole, and have it stick into the furnace an inch or two. Hence samples at least 6" long and 1 or 2 " wide can be exposed. The samples will be uncooled and will be placed in a position in the furnace where it is believed that the gas temperature will approximate the skin temperature of the object that will be constructed of the material. Because the same fuel is being used as produced the slag, this will be an excellent chance to compare the high temperature slag corrosion laboratory experiments to specimens exposed in a "real" system.

\section{RESULTS AND DISCUSSION}

Creep

The stepped load deflection data look typically as shown in Fig. 1, where the load point deflection data corrected for the deflection in the dummy fixture are shown as a function of time for Lanxide DIMOX at $1400^{\circ} \mathrm{C}$. As can be seen the creep does not reach a constant creep rate during the 100 hours, and as can be seen from Fig. 2 a steady state creep rate is not achieved even after $300 \mathrm{~h}$ at a constant stress. The deflection rate at the various stress levels were therefore obtained as the slope of the deflection curve towards the end of the $100 \mathrm{~h}$ test interval. Once the deflection rate as a function of load is obtained the strain rate can be found by using the time derivative of Eq. (2) with the obtained value of $n$.

Fig. 3 shows the strain rate vs, stress for Lanxide DIMOX measured at $1200^{\circ} \mathrm{C}$. The figure contains data obtained by both methods described above. Also shown, for comparison, are the strain rates for alumina and a $\mathrm{SiC}$ whisker reinforced alumina from ref. 5. The creep exponent, $\mathrm{n}$, is found as the slope of the curves. The magnitude of the creep exponent is an indication of the active creep mechanisms and it can be seen that there is a difference in the $n$-value for Lanxide DIMOX and the two alumina materials. 


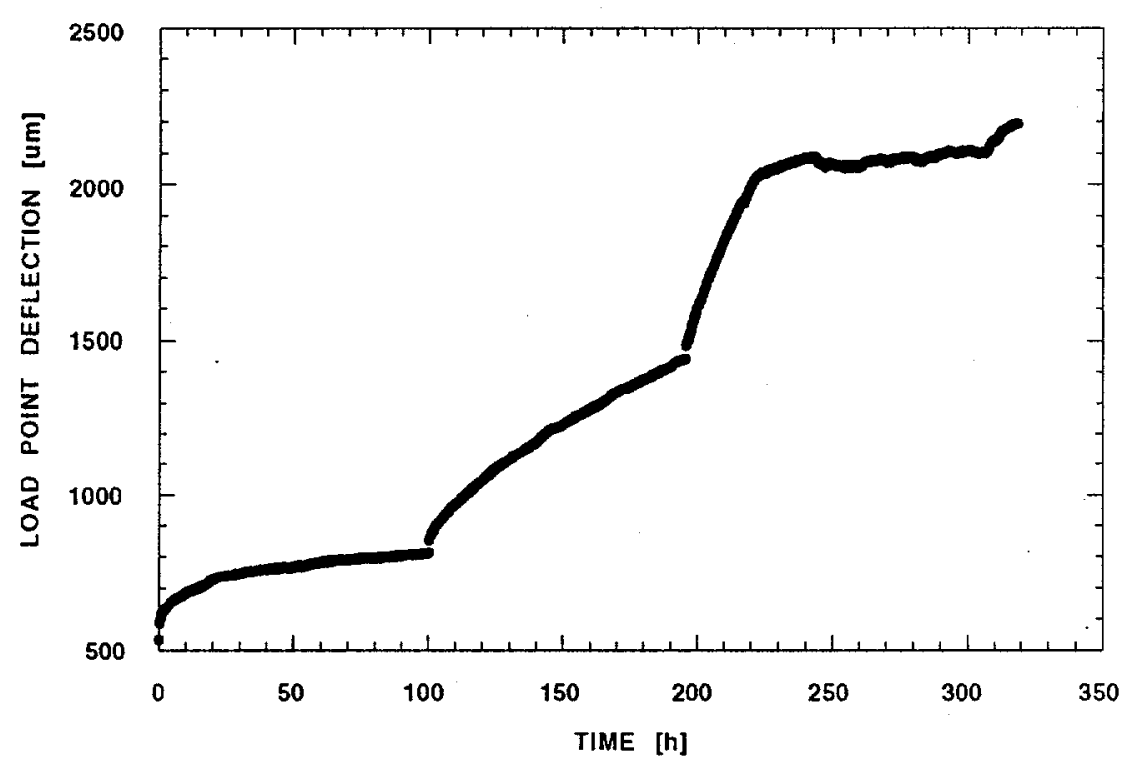

Figure 1. Load point deflection for a Lanxide DIMOX flexure bar stressed for $100 \mathrm{~h}$ each in increments of $50 \mathrm{MPa}$ at $1400^{\circ} \mathrm{C}$. The flattening out of the curve after approximately $220 \mathrm{~h}$ indicates that the specimen reached the bottom of the fixture.

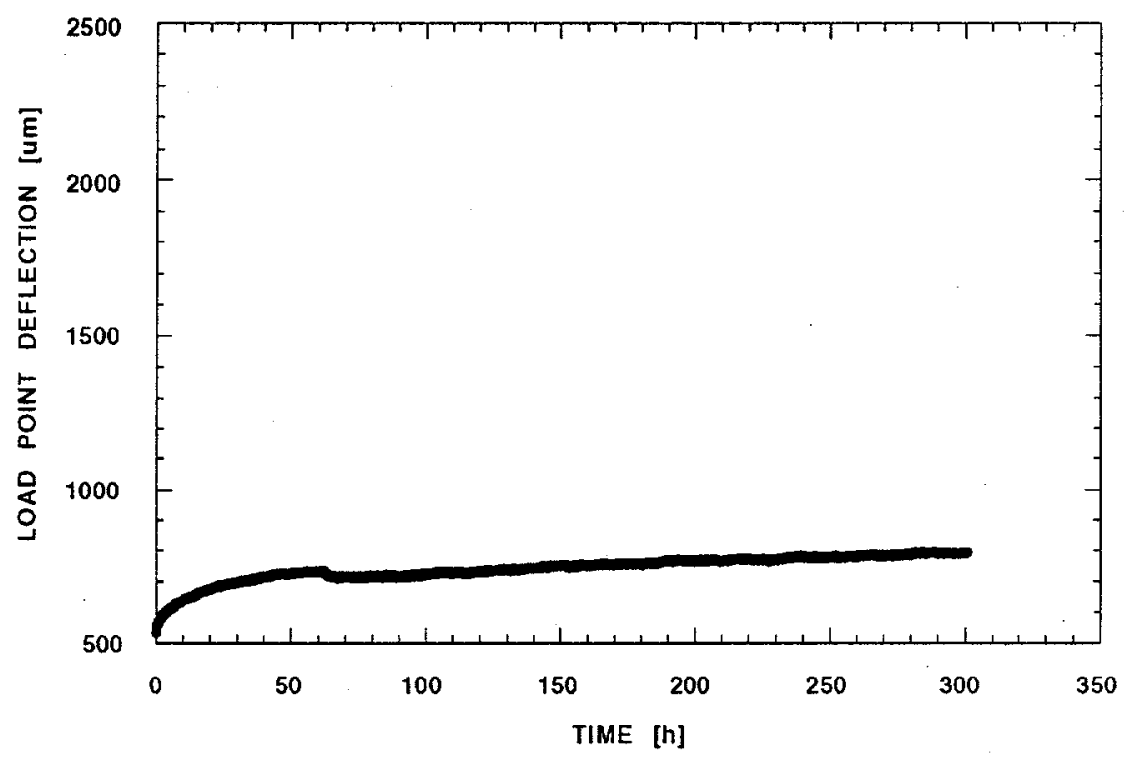

Figure 2. Load point deflection for a Lanxide DIMOX flexure bar stressed at $50 \mathrm{MPa}$ for $300 \mathrm{~h}$ at $1400^{\circ} \mathrm{C}$. 
Fig. 4 shows the strain rate vs. stress for the same materials measured at $1300^{\circ} \mathrm{C}$. It can be seen that all three materials exhibit an increase in the strain rates for a given stress over what was measured at $1200^{\circ} \mathrm{C}$, and it can also be seen that the slopes of the curve for Lanxide DIMOX has changed, indicating a change in the creep mechanism. Fig. 5 shows the strain rate as a function of stress for Lanxide DIMOX and NT230 measured at $1400^{\circ} \mathrm{C}$. A further increase in the strain rates for Lanxide DIMOX can be seen, and also the creep exponent, $n$, has increased dramatically, indicating that there is a continuos change in creep mechanism from $1200^{\circ} \mathrm{C}$ to $1400^{\circ} \mathrm{C}$. The creep rates for NT230 at $1400^{\circ} \mathrm{C}$ is comparable to the creep rates for Lanxide DIMOX at 120()$^{\circ} \mathrm{C}$. Creep experiments were carried out for NT230 at the lower temperatures as well, however, the creep rates were so low that the measured deflections lay within the accuracy of the experimental set-up.

The present results have implications for the proposed application, i.e. high temperature heat exchangers. The strain rates for Lanxide DIMOX at $1400^{\circ} \mathrm{C}$ are quite high, and in a design where even moderate localized stresses will occur, the components may be out of tolerance in an unacceptably short time. However, at $1200^{\circ} \mathrm{C}$ both the magnitude of the strain rates and the creep exponent are considerably lower, and this temperature may constitute a possible design temperature for this material. However, in order to ensure a reliable estimation of the life-time of components at this temperature, further measurements will be needed. Creep in tension and compression should be performed, as well as time to failure experiments in tension. It is further necessary 10 investigate the creep and long time failure mechanisms for the temperatures under consideration. The NT230 SiSiC exhibited improved creep properties compared to similar siliconized silicon carbides. ${ }^{7,8}$ Especially at $1200^{\circ} \mathrm{C}$ and $1300^{\circ} \mathrm{C}$ the material exhibited very little creep. At $1400^{\circ} \mathrm{C}$ some creep was measured, and further measurements in tension might be warranted also for this material. It is, however, important to keep in mind that the NT230 exhibited slow crack growth at $1400^{\circ} \mathrm{C},{ }^{3}$ and the result may be an unacceptable short lifetime at $1400{ }^{\circ} \mathrm{C}$ because of this. 


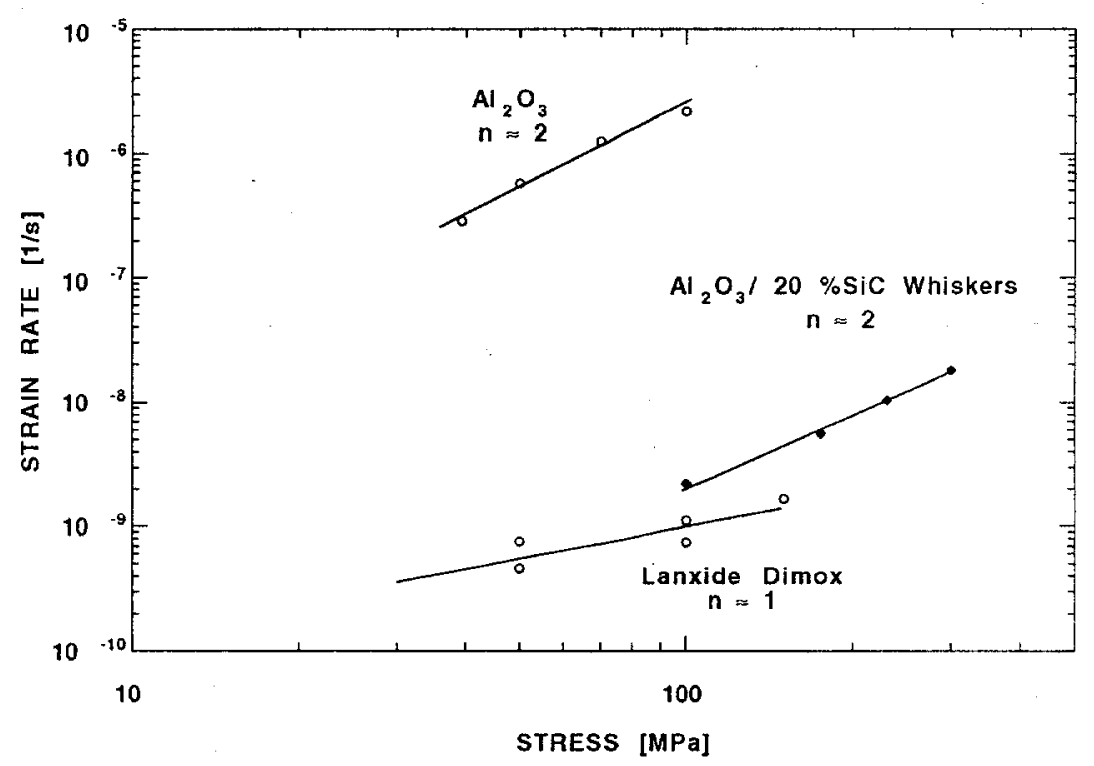

Figure 3. Strain rate vs. stress for Lanxide DIMOX, alumina and SiC whisker reinforced alumina at $1200^{\circ} \mathrm{C}$.

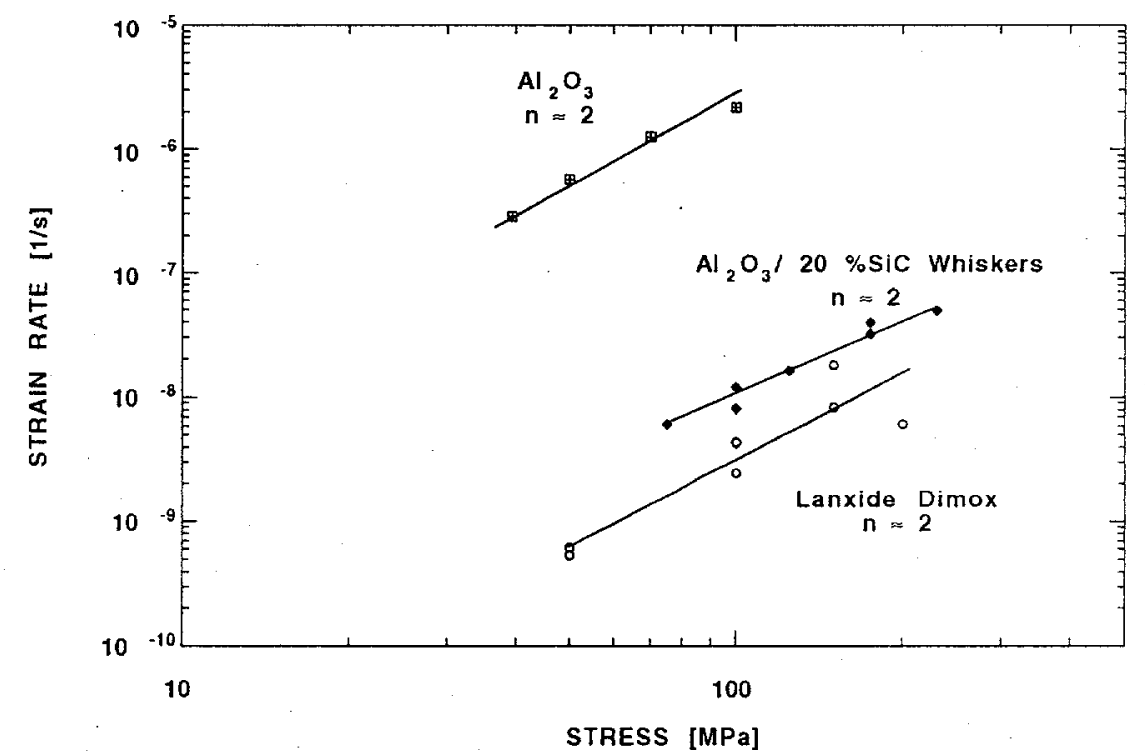

Figure 4. Strain rate vs. stress for Lanxide DIMOX, alumina and SiC whisker reinforced alumina at $1300^{\circ} \mathrm{C}$. 


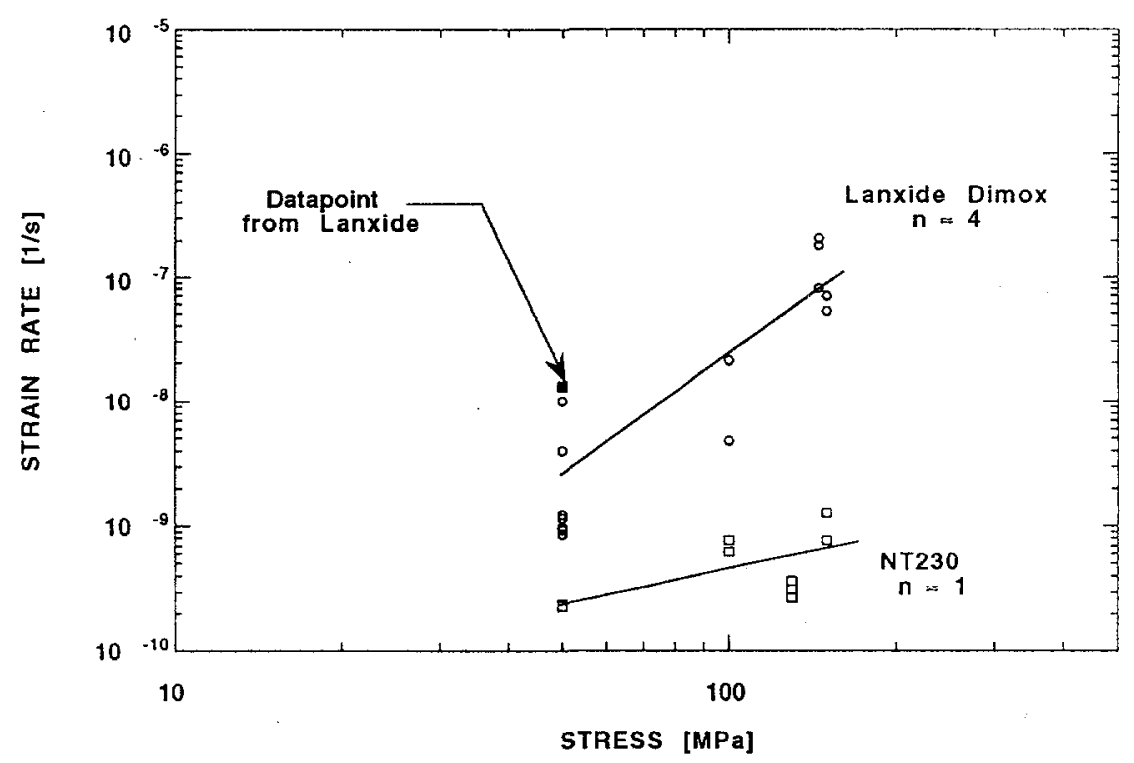

Figure 5. Strain rate vs. stress for Lanxide DIMOX and NT230 Siliconized SiC at $1400^{\circ} \mathrm{C}$

\section{REFERENCES}

1. D. J. Seery et al., "Engineering Development of Coal-Fired High -Performance Power Generation Systems," pp 188-195 in Proceedings of the Eighth Annual Coal Preparation, Utilization, and Environmental Control Contractors Conference, U.S. DOE, Pittsburgh Energy Technology Center, Pittsburgh, PA, 1992.

2. J. Shenker, "Development of a High-Performance Coal-Fired Power Generating System with a Pyrolysis Gas and Char-Fired High Temperature Furnace," pp 183-187 in Proceedings of the Eighth Annual Coal Preparation. Utilization, and Environmental Control Contractors Conference, U.S. DOE, Pittsburgh Energy Technology Center, Pittsburgh, PA, 1992.

3. K. Breder and V. J. Tennery, "Materials Support for HITAF, Final Report for Phase I," ORNL/TM-12815, Oak Ridge National Laboratory, Oak Ridge, TN, 1995. 
4. H. T. Lin and P. F. Becher, "Creep behavior of a SiC-Whisker-Reinforced Alumina," J. Am. Cer. Soc. 73 [5] 1398-81 (1990).

5. H. T. Lin and P. F. Becher, "High-Temperature Creep deformation of AluminaSiC-Whisker Composites," J. Am. Cer. Soc. 74 [8] 1886-93 (1991).

6. G. W. Hollenberg, G. R. Terwilliger, and R. S. Gordon, "Calculation of Stress and Strain in Four-Point Bending creep Tests," J. Am. Cer: Soc. 54 [4] 196-99 (1971).

7. T-J. Chuang and S. M. Wiederhorn, "Damage-Enhanced Creep in a Siliconized Silicon Carbide: Mechanics of Deformation," J. Am. Cer. Soc. 71 [7] 595-601 (1988).

8. S. M. Wiederhorn, D. E. Roberts, T-J. Chuang, and L Chuck, "DamageEnhanced Creep in a Siliconized Silicon Carbide: Phenomenology," J. Am. Cer. Soc: 71 [7] 602-608 (1988). 



\section{ENVIRONMENTAL ANALYSIS SUPPORT}

\section{R. L. Miller}

Activities in environmental analysis support included assistance to the Morgantown and Pittsburgh Energy Technology Centers (METC and PETC) in reviewing and preparing documents required by the National Environmental Policy Act (NEPA) for several projects selected for the Clean Coal Technology (CCT) Program. An important activity was the preparation for METC of a draft Environmental Assessment (EA) for the proposed Externally Fired Combined Cycle (EFCC) Project in Warren, Pennsylvania. Also prepared for METC was a draft EA for the proposed Four Rivers Project to demonstrate pressurized circulating fluidized bed (PCFB) technology in Calvert City, Kentucky. 



\title{
3.1 ENVIRONMENTAL SUPPORT TO THE CLEAN COAL TECHNOLOGY PROGRAM
}

\author{
R. L. Miller
}

Work during this period focused on the preparation for DOE's Morgantown Energy Technology Center (METC) of a draft Environmental Assessment (EA) for the Externally Fired Combined Cycle (EFCC) Project in Warren, Pennsylvania. Proposed by the Pennsylvania Electric Company (Penelec) and selected by DOE in the fifth solicitation of the CCT Program, the project would be sited at one of the two units at Penelec's Warren Station. The EFCC Project proposes to replace two existing boilers with a new "power island" consisting of a staged coal combustor, slag screen, ceramic heat exchanger, an indirectly fired gas turbine, and a heat recovery steam generator. Subsequently, Unit 2 would operate in combined-cycle mode using the new gas turbine and the existing steam turbine simultaneously. The gas turbine would generate 25 megawatts of electricity so that Unit 2 output would increase from the existing 48 megawatts generated by the steam turbine to a total of 73 megawatts. Operation of a conventional flue gas desulfurization dry scrubber as part of the EFCC technology is expected to decrease $\mathrm{SO}_{2}$ emissions by $90 \%$ per kilowatt-hour of electricity generated, and $\mathrm{NO}_{\mathrm{x}}$ emissions are anticipated to be $60 \%$ less per kilowatt-hour of electricity generated because of the staged combustor. Because the EFCC technology would be more efficient, less carbon dioxide $\left(\mathrm{CO}_{2}\right)$ would be emitted to the atmosphere per kilowatt-hour of electricity produced.

Potential resource areas of concern associated with the project include surface water resources, ecological resources, and archaeological resources. In particular, the potential effect of the heated discharge of once-through cooling water from the turbine condensers on aquatic life in the Allegheny River has been evaluated. A mussel survey conducted in September 1994 as part of the EA did not find either of the two endangered mussel species present in the vicinity of Warren Station. As recommended by the U.S. Fish and Wildlife Service, a survey was not conducted for other threatened species such as the Ohio lamprey because these species are more mobile and would be able to avoid any potential areas of adverse impact. Archaeological investigations have identified significant prehistoric, protohistoric, and historic occupations on the Warren Station site. There has been an ongoing investigation at this site, which is fenced and located east of the proposed project site near the eastern boundary of Warren Station. A cultural 
resources survey recommended no further investigation of the proposed construction site because it has already been extensively disturbed and graded. However, it is expected that a plan would be developed for dealing with unanticipated finds during construction. Finally, Penelec has committed to installing liners at the active ash disposal area and ash ponds to minimize potential impacts to the groundwater.

Another draft EA was also prepared for METC during this period for the Four Rivers Project in Calvert City, Kentucky. Proposed by Air Products and selected by DOE in the fifth solicitation of the CCT Program, the project would be sited adjacent to the existing Air Products chemical manufacturing facility. The Four Rivers Project proposes to demonstrate pressurized circulating fluidized bed (PCFB) technology as part of a new cogeneration facility. The 95megawatt (equivalent) coal-fired facility would provide approximately 70 megawatts of electricity to the Tennessee Valley Authority and 310,000 pounds of steam per hour to the adjacent Air Products facility. The proposed facility would operate in a combined cycle: a gas turbine would generate approximately 38 megawatts, and a steam turbine would generate about 32 megawatts. Steam extracted from the steam turbine would be piped to the Air Products facility. The proposed project would replace Air Products' two 35-year-old coal-fired boilers that currently provide steam to the facility.

Overall, the proposed project is expected to improve the environment of the surrounding area. During operation of the facility, emissions of $\mathrm{SO}_{2}, \mathrm{NO}_{\mathrm{x}}$, and particulate matter are expected to decrease from current levels associated with the two existing boilers. Consequently, the proposed project would also reduce the potential contribution to visibility degradation and acid deposition. The proposed construction of the facility is expected to benefit the socioeconomic structure of the local communities and the region. Construction workers would be the largest contributors to the nearby communities. Impacts on public services, infrastructure, and recreational resources would be negligible. 


\section{BIOPROCESSING RESEARCH}

\section{T. C. Scott}

This section describes research and development activities performed for the Fossil Energy Bioprocessing Research Program. Work on the Fossil Energy Bioprocessing Research Program includes fundamental research for coal applications that investigates the use of enzymes in organic media, bioreactor development for coal liquefaction, and separations of enzyme and coal liquids. In addition, there are studies on advanced bioreactor systems for treatment of gaseous substrates, removal of heteroatoms and metals from heavy oils, and renewable hydrogen production for fossil fuel processing. 



\title{
4.1 FUNDAMENTAL BIOPROCESSING RESEARCH FOR COAL APPLICATIONS
}

\author{
E. N. Kaufman and T. C. Scott
}

\section{INTRODUCTION}

The purpose of this program is to gain a fundamental understanding and sound scientific and technical basis for evaluating the potential roles of innovative bioprocessing concepts for the utilization and conversion of coal. The aim is to explore the numerous ways in which advanced biological processes and techniques can open new opportunities for coal utilization or can replace more conventional techniques by using milder conditions with less energy consumption or loss.

There are several roles where biotechnology is likely to be important in coal utilization and conversion. These include potential bioprocessing systems such as conversion of coal to liquids or gases; biocatalytic beneficiation of coal-derived liquids for the removal of heteroatoms or heavy metals; biocatalytic upgrading of coal-derived liquids and conversion to useful chemical feedstocks; biocatalytic removal of $\mathrm{SO}_{x}$ and $\mathrm{NO}_{x}$ from coal combustion off-gas; environmental control technology for the removal or destruction of hazardous materials in process effluents and/or solid residues; and the removal and utilization of $\mathrm{CO}_{2}$ from combustion off-gas. Effective bioprocesses for such applications will require detailed knowledge of the biological process mechanisms and advanced bioreactor technology that can be optimized for high productivity, as well as supporting upstream and downstream processes that will allow an effective integrated bioprocess. Of particular interest is the development of predictive models that can be used for process design and scaleup. In this program, a generic approach is taken so that there will be utility over a broad range of applications. In conjunction with the generic approach, model experimental systems that address real-world problems are used to verify the results. 


\section{DISCUSSION OF CURRENT ACTIVITIES}

The efforts in FY 1994-1995 have been directed toward three primary areas of research: (1) study and development of Advanced Bioreactor Concepts; (2) use and enhancement of Biological Catalysts in Organic Media; and (3) Separation Concepts related to biocatalysts-coal interactions.

\section{Advanced Bioreactor Concepts}

In order to be economically feasible, all of the potential applications of biotechnology to coal processing will require efficient and inexpensive bioreactors and contactors. Biocatalysts and reactor schemes for further processing the coal-derived liquid produced must also be addressed. The aim of this task is to develop advanced bioreactor concepts that are compatible with continuous operation and maximum throughput. Three reactor configurations are being considered: (1) a fluidized-bed bioreactor that allows the direct contacting of coal particles with the biocatalyst (microorganisms or enzymes) in an aqueous or organic liquid; (2) columnar bioreactors, either fixed bed or fluidized bed, that can operated with a continuous gas phase or at least with a high gas loading; and (3) a liquid-liquid contacting system in which the biocatalyst in an aqueous liquid contacts an immiscible organic liquid such as a coal-derived liquid.

In the past year, we have completed the development of a fully predictive mathematical model describing liquid/solid fluidized-bed reactors for coal solubilization. Tremendous progress has been made in this area, resulting from an extremely effective collaboration with Washington State University. Unique features of the model include the capability to describe the behavior of a multivariant particle system which can have distributions in both particle size and density, boundary conditions which allow for particle elutriation, and the inclusion of reactive terms which allow tracking of particle dissolution. The model was validated on both the macroscopic (ability to predict solids hold dup and microscopic scales (ability to predict particle segregation) through novel experimental techniques developed at ORNL. This patented fluorescence visualization method was used to supply particle segregation data as a function of flow rate, coal charge, and axial position. This data served to demonstrate the fully predictive nature of 
the mathematical model (Fig. 1). The utility of the bed performance model was also demonstrated by its ability to forecast the optimal coal feed size and rate as well as liquid velocity to maximize coal conversion in the fluidized-bed reactor. The model was further applied to the flood/drain bioreactor developed for desulfurization at Idaho National Engineering Laboratory.
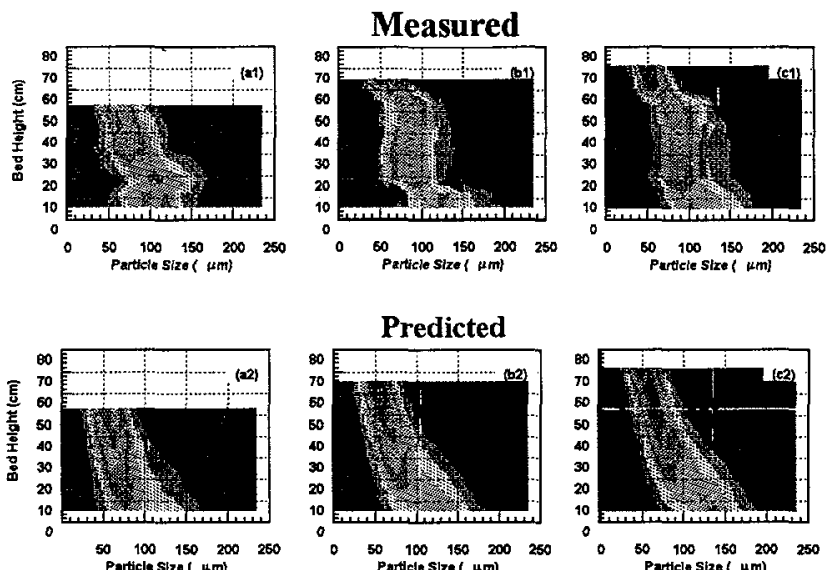

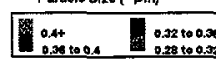

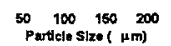

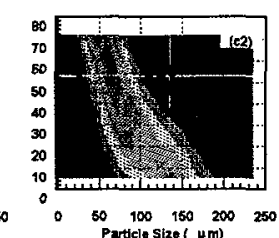

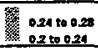

0.0 .10 .02

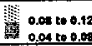

Figure 1. Measured and predicted particle size distributions as a function of axial position and fluid velocity. Our fully predictive mathematical model of fluidized-bed performance accurately forecasts microscopic bed behavior as measured using a novel fluorescence visualization technique.

Progress has also been made in the development of a liquid-liquid electro-spray bioreactor. This reactor system has the advantage of producing micron-size drops over conventional liquid-liquid contactors. Instead of agitation, an electric field is used to create a micro-emulsion. Work is currently focused on two areas: (1) to study the viability of bacteria as they pass through a pulsed electric field, and (2) to measure the produced drop size as a function of operating conditions. A kerosene-water model system is used in these studies with Pseudomonas bacteria.

\section{Biological Catalysts in Organic Media}

There are several potential coal bioprocessing concepts that could use an organic solvent or produce liquid organic products, for example, the bioconversion of coal to 
liquids in an organic solvent or the bioprocessing of coal-derived liquids. For such a process, the biocatalyst (microorganism or enzyme) must be compatible with the organic medium.

Primary efforts continue to emphasize the use of modified enzymes, soluble and active in organic solvents, for the conversion of coal, coal-derived liquids (from a coal liquefaction pilot plant), and coal model compound. Modification of hydrogenases, extracted from both mesophilic and thermophilic bacteria, has been achieved using activated polyethylene glycol whose polar molecular region binds with the enzyme but whose aromatic moieties ensure increased compatibility of the enzymes with organic media. Redox dyes have been used to mediate hydrogenation reactions which occur in coal enzymatic interactions. They have replaced cytochrome $\mathrm{c}$ because of their low cost and solubility and reducibility in organic solutions without modification. Experiments continue to be conducted in shake or stirred flasks with coal or coal-related compounds contacting modified enzymes in organic solutions in a reducing atmosphere. Some work has also been carried out in shake flasks in which biocatalysts and organic dyes solubilized in an aqueous phase were contacted with both an immiscible organic solvent and coal particles. This has proved to be a versatile biphasic model. Reactions in this system may occur across the aqueous/organic interface or separately in either phase depending on the solubility characteristics of the dyes and enzymes and the relative hydrophobicity or density of the coal or coal-derived substrate.

\section{Separation Concepts}

Chemical and/or physical separations are usually a necessary part of any bioprocessing concept. This will certainly be true for processes in which biocatalysts interact with coal. Of particular interest will be the separation of product components or fractions from an organic liquid mixture and the recovery and recycle of dissolved biocatalysts (e.g., chemically modified enzymes or whole cells). Conventional separation of coal-derived liquids is through distillation. This process is highly energy intensive, and the temperatures required would not be compatible with biocatalyst viability. Enzymes or whole cells when used in aqueous systems may be separated by means of filtration. We 
will investigate the compatibility of various membrane systems with the range of solvents that would be present in our organic coal-derived liquid product.

An alternative approach will be to study adsorption systems in which solid particulates are used in appropriate contactors to first recover the used biocatalyst and then to fractionate the resulting product into classes of compounds (saturates, aromatics, oxychemicals, etc.). Inorganic adsorbents (such as silica gel, alumina, and titania activated with varying amounts of water) will be the first material tested for the fractionation of the organics. Weak ion-exchange materials will be the adsorbents of choice for enzyme isolation. Such solid-phase adsorption systems are already in commercial operation for the separation of mixed aromatics, branched cycloalkanes, olefins, and paraffins. They may be utilized for thousands of adsorptic/regeneration cycles and may be reprocessed at the end of their useful lifetime. Additionally, solid sorbents pose an advantage over liquid extraction since there is no loss of reagent due to solubility in other liquid phases or through evaporation. Regeneration is also less energy intensive.

- Tests will be made with actual process mixtures in bench-scale contactors. The effect of temperature, solid/liquid ratio, biocontacting configuration, and choice of the adsorbent material will be determined.

\section{PUBLICATIONS}

1. M. Asif and J. N. Petersen, "Particle Dispersion in a Binary-Solid Liquid Fluidized Bed," AIChE J. 39(9), 1465-1471 (1993).

2. M. Asif, J. N. Petersen, E. N. Kaufman, J. M. Cosgrove, and T. C. Scott, "A Dynamic Model of the Hydrodynamics of a Liquid Fluidized Bed," Ind. Eng. Chem. Res. 33, 2151-2156 (1994).

3. M. Asif, J. N. Petersen, T. C. Scott, and J. M. Cosgrove, "Hydrodynamic Studies of an Advanced Fluidized Bed Bioreactor for Direct Coal Liquefaction." Appl. Biochem. Biotechnol. 39/40, 535 (1993).

4. E. N. Kaufman, M. H. Little, C. A. Woodward, and C. D. Scott, "Enzymatic and Hydrodynamic Studies of a Liquid/Solid Fluidized-Bed Reactor for Coal Bioconversion," TMS (in press). 
5. E. N. Kaufman, J. N. Petersen, Y. Wang, and M. H. Little, "Experimental and Numerical Characterization of Liquid Fluidized Beds of Coal," Chem. Eng. Sci. (in press).

6. E. N. Kaufman and C. D. Scott, "Liquefy Coal with Enzyme Catalysts." CHEMTECH 24(4), 27-32 (1994).

7. E. N. Kaufman, C. D. Scott, T. C. Scott, and C. A. Woodward, "Use of Biocatalysts for the Solubilization/Liquefaction of Bituminous Coal in a Fluidized-Bed Reactor," American Chemical Society, Division of Fuel Chemistry 205th National Meeting, Denver, $\mathrm{CO}$.

8. E. N. Kaufman, C. D. Scott, C. A. Woodward, and T. C. Scott, "Use of Modified Enzymes for the Solubilization/Liquefaction of Bituminous Coal in a Fluidized-Bed Reactor," Appl. Biochem. Biotechnol. (in press).

9. E. N. Kaufman and T. C. Scott, "In Situ Visualization of Coal Particle Distribution in a Liquid Fluidized Bed Using Fluorescence Microscopy," Powder Technology 78(3), 239-246 (1994).

10. H. M. Lizama and E. N. Kaufman, "Biotreatment of $\mathrm{H}_{2} \mathrm{~S}$ in the Petroleum Industry," $T M S$ (in press).

11. C. D. Scott, T. C. Scott, and C. A. Woodward, "The Chemical Modification of Enzymes to Enhance Solubilization and Activity in Organic Solvents for Interaction with Coal," Fuel 72(12), 1695-1700 (1993).

12. C. D. Scott, T. C. Scott, and C. A. Woodward, "Use of Dinitrofluorobenzene to Modify Enzymes for Enhanced Solubilization and Activity in Organic Solvents." Appl. Biochem. Biotechnol. 39/40, 279-287 (1993).

13. C. D. Scott, C. A. Woodward, and T. C. Scott, "Mechanisms and Effects of Using Chemically Modified Reducing Enzymes to Enhance the Conversion of Coal to Liquids," Fuel Process. Technol. 40, 319-329 (1994).

14. C. D. Scott, C. A. Woodward, and T. C. Scott, "Use of Chemically Modified Enzymes in Organic Solvents for Conversion of Coal to Liquids." Catalysis Today 19, 381-394 (1994).

15. T. C. Scott, J. M. Cosgrove, M. Asif, and J. N. Petersen, "Hydrodynamic Studies of an Advanced Fluidized-Bed Bioreactor for Direct Interaction with Coal," Fuel 72(12), 1701-1704 (1993). 
16. T. C. Scott, E. N. Kaufman, J. M. Cosgrove, M. Asif, and J. N. Petersen, "Hydrodynamic Behavior of a Liquid-Solid Fluidized-Bed Reactor for the Bioconversion of Coal Particles to Liquid Products," Fuel Process. Technol. 40, 241-249 (1994).

17. Y. Wang, J. N. Petersen, and E. N. Kaufman, "Modeling the Biological Solubilization of Coal in a Liquid Fluidized-Bed Reactor," Appl. Biochem. Biotechnol. (in press). 



\title{
4.2 ADVANCED BIOREACTOR SYSTEMS FOR GASEOUS SUBSTRATES: CONVERSION OF SYNTHESIS GAS TO LIQUID FUELS AND REMOVAL

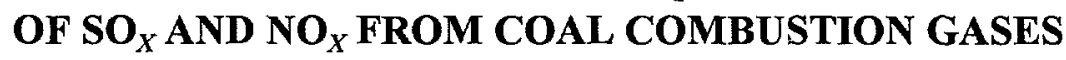

\author{
P. T. Selvaraj and E. N. Kaufman
}

\section{INTRODUCTION}

The purpose of the proposed research program is the development and demonstration of a new generation of gaseous substrate-based bioreactors for the production of liquid fuels from coal synthesis gas and the removal of $\mathrm{NO}_{x}$ and $\mathrm{SO}_{x}$ species from combustion flue gas. This R\&D program is a joint effort between the staff of the Bioprocessing Research and Development Center (BRDC) of ORNL and the staff of Bioengineering Resources, Inc. (BRI), under a Cooperative Research and Development Agreement (CRADA). The Federal Coordinating Council for Science, Engineering, and Technology report entitled Biotechnology for the 21st Century ${ }^{1}$ and the recent Energy Policy Act of 1992 emphasize research, development, and demonstration of the conversion of coal to gaseous and liquid fuels and the control of sulfur and nitrogen oxides in effluent streams. ${ }^{2}$ This proposed R\&D program presents an innovative approach to the use of bioprocessing concepts that will have utility in both of these identified areas.

Coal is thermochemically converted to synthesis gas consisting of carbon monoxide, hydrogen, and carbon dioxide. Conventional catalytic upgrading of coal synthesis gas into alcohols or other oxychemicals is subject to several processing problems such as interference of the other constituents in the synthesis gases, strict $\mathrm{CO} / \mathrm{H}_{2}$ ratios required to maintain a particular product distribution and yield, and high processing cost due to the operation at high temperatures and pressures. Recently isolated and identified bacterial strains capable of utilizing $\mathrm{CO}$ as a carbon source and converting $\mathrm{CO}$ and $\mathrm{H}_{2}$ into mixed alcohols offer the potential of performing synthesis gas conversion using biocatalysts. ${ }^{3}$ Biocatalytic conversion, though slower than the conventional process, has several advantages such as decreased interference of the other constituents in the synthesis gases, no requirement for strict $\mathrm{CO} / \mathrm{H}_{2}$ ratios, and decreased capital and operating costs as the biocatalytic reactions occur at ambient temperatures and pressures. Several biocatalytic schemes have been proposed for the 
production of alcohols from synthesis gas. Clostridium ljundahlii catalyzes conversion of $\mathrm{CO}, \mathrm{H}_{2}$, and $\mathrm{CO}_{2}$ into acetate and ethanol. However, the efficient biocatalytic production of liquid fuels from synthesis gas is constrained by the low solubility of substrates and the high cell density required for timely and complete substrate conversion. Therefore, the commercializable liquid fuel production will require the design of novel gas-phase bioreactors that combine high cell density with high product yield and high rate of substrate flux to the biocatalyst.

Development of such gas-phase bioreactors also has application in the removal of $\mathrm{SO}_{x}$ and $\mathrm{NO}_{x}$ constituents from coal combustion flue gases, since the two are analogous processes with many of the same types of process restraints and problems. Microorganisms such as sulfate-reducing bacteria (SRB) and Pseudomonas denitrificans have been shown to interact with $\mathrm{SO}_{x}$ and $\mathrm{NO}_{x}$ respectively ${ }^{4,5}$, however, efficient bioreactor systems for possible use in flue gas processing have not been developed and tested.

This research investigates optimal bacterial strains, growth media, kinetics, cell immobilization, and economic carbon and energy sources for the reduction of gaseous flue gas constituents. However, the primary emphasis will be on the development of advanced bioreactor systems coupled with innovative biocatalytic systems that will provide increased productivity under controlled conditions. This should result in bioprocessing options that have both technical and economic feasibility, thus ensuring early industrial use. Predictive mathematical models will be formulated to accommodate hydrodynamics, mass transport, and conversion kinetics and to provide the data base for design and scaleup. The program has been separated into four tasks: (1) optimization of Biocatalyst Kinetics; (2) development of Well-mixed and Columnar Reactors; (3) development of Predictive Mathematical Models; (4) Industrial Demonstration. 


\section{DISCUSSION OF CURRENT ACTIVITIES}

Optimization of Biocatalytic Kinetics

Research conducted at ORNL during FY 1994 has established the anaerobic techniques for handling the bacterial strains for reduction of $\mathrm{SO}_{2}$ to $\mathrm{H}_{2} \mathrm{~S}$ and the analytical techniques to monitor substrate and product streams. After screening several pure and mixed bacterial strains, a mixed SRB culture was found to be the promising culture for microbial reduction of $\mathrm{SO}_{2}$ to $\mathrm{H}_{2} \mathrm{~S}$. Anaerobically digested municipal sewage sludge (AD-MSS) medium has been used as the sole carbon and energy source for the microbial process. Municipal sewage sludge is readily available at a negative or near zero cost. A chemostat reactor has been operated utilizing mixed SRB in AD-MSS medium with complete conversion of $\mathrm{SO}_{2}$ to $\mathrm{H}_{2} \mathrm{~S}$. A continuous process of producing AD-MSS medium with increasing amounts of fermentable substrates for SRB cultures has been initiated. Various techniques have been investigated for immobilizing the process cultures so that the bioreactors could be operated with high cell density to obtain maximum volumetric productivity.

\section{Development of Well-Mixed and Columnar Reactors}

Preliminary experiments have been conducted with alginate immobilized cells in wellmixed and columnar reactors as shown in Figs. 1 and 2.

Complete removal of $\mathrm{SO}_{2}$ was observed at sulfite concentrations of about $140 \mathrm{mg} / \mathrm{L}$ in the columnar reactor with hydraulic contact time of $5.7 \mathrm{~h}$ (Fig. 3). However, the gradual disintegration of alginate-cell beads has been observed in the columnar reactor within 4 days. The breaking up of the alginate beads with mechanical agitation hindered the operation of the well-mixed reactor. An alternate immobilization technique is currently being investigated to withstand the mechanical agitation and chemical disruption. The bench-scale well-mixed and columnar reactors will be operated following the successful immobilization technique for a period of time to obtain sufficient data to evaluate economic analysis of the scaleup process. 


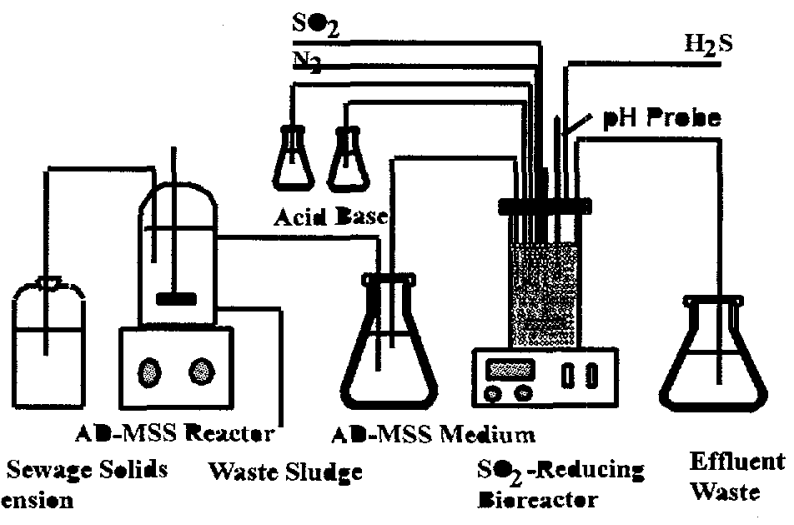

Figure 1. Immobilized cell well-mixed reactor.

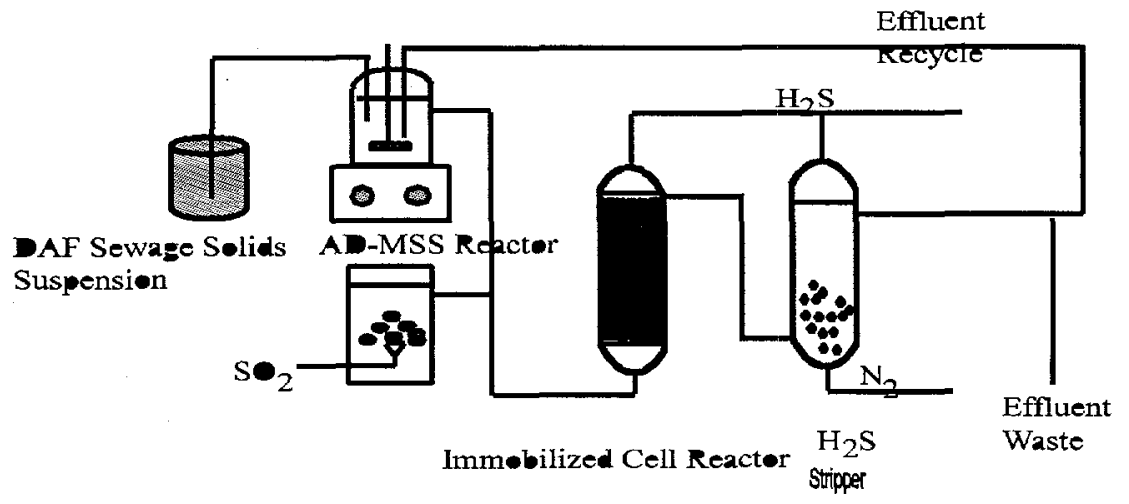

Figure 2. Immobilized cell columnar reactor.

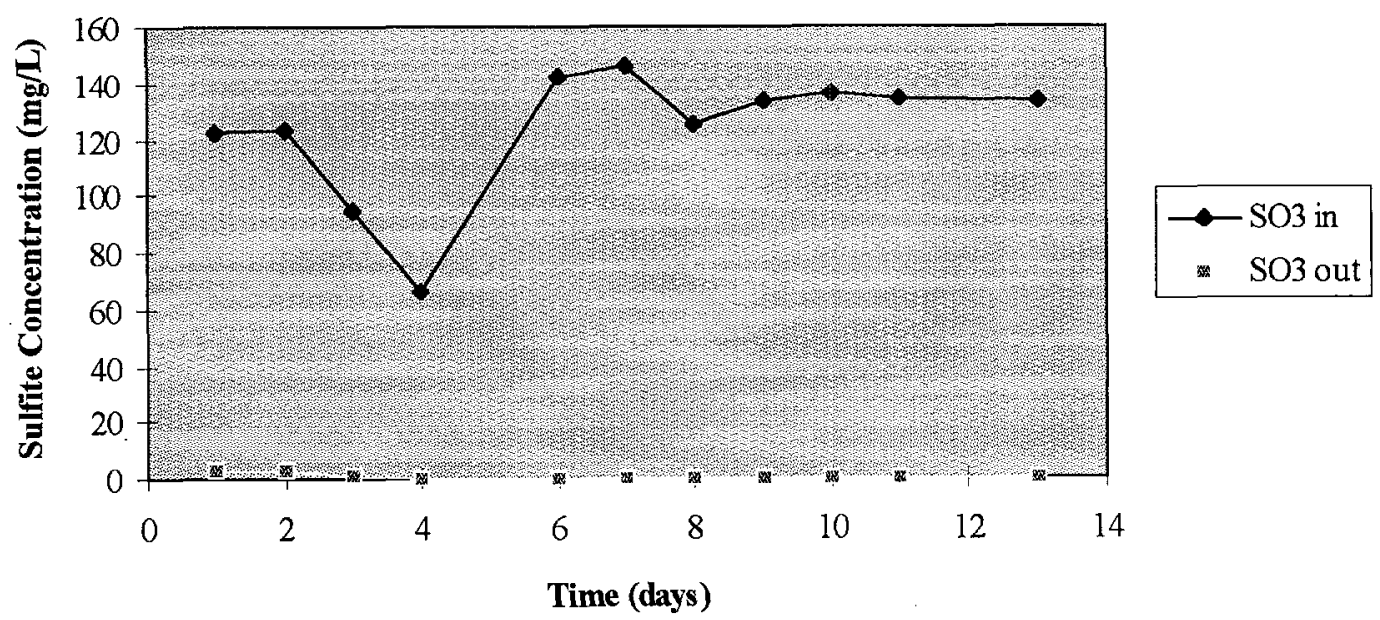

Figure 3. $\mathrm{SO}_{2}$-reducing columnar reactor with alginate-cell beads. 


\section{REFERENCES}

1. D. J. Galas, et al., p. 27 in Biotechnology for the 21 st Century, Federal Coordinating Council for Science, Engineering, and Technology, Washington, D.C. (1992).

2. House of Representatives, Energy Policy Act of 1992, Conference Report to Accompany H.R. 776, U.S. Government Printing Office, Washington, D.C. (1992).

3. R. M. Worden, et al, Fuel 70, 615 (1991).

4. K. L Sublette, et al., p. 5-49 in Proceedings of the First International Symposium on the Biological Processing of Coal, ed. S. Yunker and K. Rhee, Electric Power Research Institute Report GS-6970 (1990).

5. W. A. Apel and C. E. Turick, "The Use of Denitrifying Bacteria for the Removal of Nitrogen Oxides from Combustion Gases," Fuel (in press). 



\title{
4.3 REMOVAL OF HETEROATOMS AND METALS FROM HEAVY OILS BY BIOCONVERSION PROCESSES
}

\author{
T. C. Scott, H. M. Lizama, T. L. Takeuchi, and E. N. Kaufman
}

\section{INTRODUCTION}

Biocatalysts, either appropriate microorganisms or isolated enzymes, are being used in an aqueous phase in contact with heavy oils to extract and convert heteroatoms such as sulfur. Sulfate-reducing bacteria (SRB) are being investigated for the reductive removal of organically bound sulfur, and bacteria such as Rhodococcus are being utilized for the oxidative removal of organic sulfur. These types of interactions will ultimately be carried out in advanced bioreactor systems where the oil and aqueous-phase biocatalysts will be contacted using high-intensity transient electric fields. The ultimate goal of the program is demonstration of heteroatom-removal technology at an industrial site. The research program is a Cooperative Research and Development Agreement (CRADA) between ORNL and six industrial firms: (1) Texaco, (2) Energy Biosystems, (3) Exxon, (4) Baker Performance Chemicals, (5) Chevron, and (6) Unocal.

\section{DISCUSSION OF CURRENT ACTIVITIES}

This program began operations in late March 1994. During the elapsed time period, all of the industrial partners have officially signed the CRADA. During October 11-13, 1995, a CRADA and program review meeting was held at ORNL and at Brookhaven National Laboratory. At that time, Texaco and Energy Biosystems were the only two of the six CRADA partners that had officially signed the agreement; hence, they were the only two companies in attendance. Since that time, Exxon and Baker Performance Chemicals have visited ORNL to hold mini-sessions on program progress. Unocal and Chevron are yet to visit ORNL and receive a full program update. ORNL will attempt to set a review meeting for all participants for the week of April 17-21, 1995, in Oak Ridge.

During this reporting period, the emphasis on technical issues at ORNL has focused on biodesulfurization with SRB. SRB have been successfully grown in a biphasic system 
where organic sulfur is present in an organic phase while the biocatalyst is suspended in an aqueous phase. Equal volumes $(400 \mathrm{~mL})$ of aqueous microbial medium and kerosene in a 2-L bottle with a hydrogen atmosphere were brought into intimate contact by way of a magnetic stirring bar. The sole electron acceptor available for bacterial growth was the model compound dibenzothiophene (DBT), which was dissolved in the kerosene. Growth was confirmed by the generation of $\mathrm{H}_{2} \mathrm{~S}$, which precipitated as $\mathrm{FeS}$ in the aqueous phase. This indicates that the SRB could interact with the DBT in the organic media and also establishes that the biocatalyst is not adversely affected by the hydrocarbons.

The next step in development has been design and operation of a batch biphasic stirred-tank reactor. In this reactor DBT is dissolved in kerosene in the range of 5 to $25 \mathrm{~g} / \mathrm{L}$. The kerosene phase is dispersed in the aqueous medium containing the SRB by impeller agitation. Hydrogen gas is used to continuously sweep the headspace of the reactor. Sulfur utilization is followed by monitoring the concentration of DBT in the organic phase and by gas-phase measurements for $\mathrm{H}_{2} \mathrm{~S}$. Detailed data on drop-size distributions and surface area per unit volume have been taken in order to characterize the hydrodynamics of the biphasic liquid-liquid reactor. Experiments with mesophilic SRB at $30^{\circ} \mathrm{C}$ have shown that the organisms grow to reasonable cell densities without any special treatment. In addition, the liquid-liquid dispersion easily coalesces to form two separate phases when agitation is turned off.

The electric dispersion reactor system is still under construction and being tested; however, a few initial tests of effects of the electric field on microorganisms have shown no deleterious effects on growth or viability. 


\title{
4.4 RENEWABLE HYDROGEN PRODUCTION FOR FOSSLL FUEL PROCESSING
}

\author{
E. Greenbaum, J. W. Lee, C. V. Tevault, S. L. Blankinship, and L. J. Mets
}

\section{INTRODUCTION}

In the fundamental biological process of photosynthesis, atmospheric carbon dioxide is reduced to carbohydrate using water as the source of electrons with simultaneous evolution of molecular oxygen: $\mathrm{H}_{2} \mathrm{O}+\mathrm{CO}_{2}+$ light $-\mathrm{O}_{2}+\left(\mathrm{CH}_{2} \mathrm{O}\right) \cdot{ }^{1}$ It is well established that two light reactions, Photosystems I and II (PSI and PSII) working in series, are required to perform oxygenic photosynthesis. Experimental data supporting the two-light reaction model are based on the quantum requirement for complete photosynthesis, spectroscopy, and direct biochemical analysis. ${ }^{2-15}$ Some algae also have the capability to evolve molecular hydrogen in a reaction energized by the light reactions of photosynthesis. This process, now known as biophotolysis, ${ }^{16}$ can use water as the electron donor and lead to simultaneous evolution of molecular hydrogen and oxygen. ${ }^{13}$ In green algae, hydrogen evolution requires prior incubation under anaerobic conditions. Atmospheric oxygen inhibits hydrogen evolution and also represses the synthesis of hydrogenase enzyme. ${ }^{17} \mathrm{CO}_{2}$ fixation competes with proton reduction for electrons released from the photosystems. ${ }^{18}$ Interest in biophotolysis arises from both the questions that it raises concerning photosynthesis and its potential practical application as a process for converting solar energy to a non-carbon-based fuel. ${ }^{16}$ Prior data supported the requirement for both Photosystem I and Photosystem II in spanning the energy gap necessary for biophotolysis of water to oxygen and hydrogen. ${ }^{19,13}$ In this paper we report that PSII alone is capable of driving sustained simultaneous photoevolution of molecular hydrogen and oxygen in an anaerobically adapted PSI-deficient strain of Chlamydomonas reinhardtii, mutant $\mathrm{B} 4$, and that $\mathrm{CO}_{2}$ competes as an electron acceptor. Light-dependent

photoassimilation of $\mathrm{CO}_{2}$ is sustained in the mutant at rates and quantum yields that are comparable with those of wild-type alga, both under anaerobic and initial aerobic conditions. 
Taken together, the results imply that these algae have efficient biochemical mechanisms for spanning the energy gap between oxygen evolution and $\mathrm{H}_{2}$ evolution or $\mathrm{CO}_{2}$ reduction with only PSII acting as a light trap.

\section{MATERIALS AND METHODS}

Mutant B4 of Chlamydomonas reinhardtii, deposited with the Duke University Chlamydomonas Genetics Center and available as Stock No. CC2933, was obtained following metronidazole enrichment described in detail elsewhere. ${ }^{20}$ Analysis of the algal cultures before and after the experiments indicated that this mutant had a chlorophyll fluorescence induction transient characteristic of PSI-deficient strains ${ }^{21}$ and lacked the reaction center core (CPI) complex in electrophoresis at $4^{\circ} \mathrm{C}$. P700 signals were undetectable, as was the $\mathrm{G}=2.007 \mathrm{EPR}$ signal characteristic of PSI ${ }^{22}$ Genetic analysis indicated that the B4 mutation is carried in a nuclear gene and is unable to assemble the functional message for the psaA gene encoding one of the two major apoproteins of the PSI complex. This property has been described previously for several other nuclear gene mutants of $C$. reinhardtii that evidently encode components essential for the trans-splicing of this tripartite message. ${ }^{23}$ In the absence of the psaA message, the cells were unable to synthesize any PSI complexes. Experiments using Schott 730-nm cut-off filters discussed below (Figs. 1A and 1C) demonstrated the expected photoresponse for absence of PSI in mutant B4 and its presence in wild-type Chlamydomonas.

\section{RESULTS}

Figure 1A demonstrates simultaneous nonsaturated photoevolution of molecular hydrogen and oxygen from mutant $\mathrm{B} 4$ in an atmosphere of $363 \mathrm{ppm} \mathrm{CO}_{2}$ in helium; Figure 1B contains data for the simultaneous photoevolution of hydrogen and oxygen in pure helium. Figures $1 \mathrm{C}$ and 1D contain corresponding data for wild-type Chlamydomonas 137c. Mutant B4 was grown photoheterotrophically using minimal growth medium with acetate. The reaction itself was performed in minimal growth medium by successive washings to eliminate all soluble acetate. Data for mutant B4 and the control wild-type $137 \mathrm{c}$ were obtained 

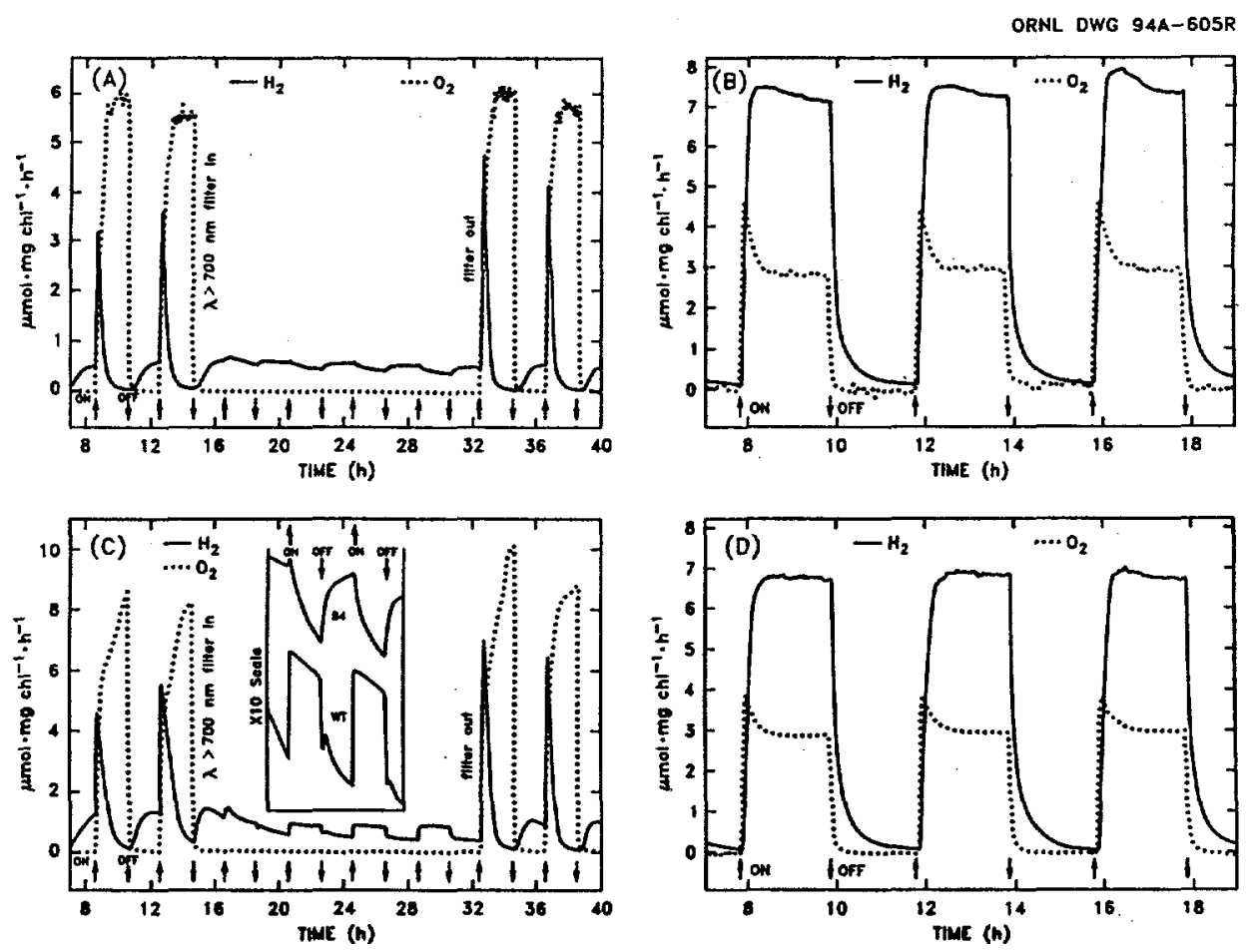

Figure 1. Simultaneous photoevolution of molecular hydrogen and oxygen by

Chlamydomonas mutant B4 and wild-type Chlamydomonas $137 \mathrm{c}$ with nonsaturating light. (A) mutant B4, $363 \mathrm{ppm} \mathrm{CO}_{2}$ in helium; (B) mutant B4, helium; (C) wild-type, $363 \mathrm{ppm}$ $\mathrm{CO}_{2}$ in helium; (D) wild-type, helium. As indicated in the insert of Fig. $1 \mathrm{C}$, irradiation with light of wavelength $\lambda>700 \mathrm{~nm}$ generated Photosystem I-dependent hydrogen evolution in $137 \mathrm{c}$, whereas no such hydrogen evolution was observed in mutant B4. In Figs. $1 \mathrm{~A}$ and $1 \mathrm{C}$, the peak and decline of hydrogen evolution while the light is still on represents the real-time activation of the Calvin-Benson cycle following a period of darkness. The chlorophyll concentration for the experiments of Figs. $1 \mathrm{~A}$ and $1 \mathrm{C}$ was $15 \mu \mathrm{g} / \mathrm{ml}$; for Figs. 1B and 1D it was $3 \mu \mathrm{g} / \mathrm{ml}$. 
simultaneously in a dual-photoreaction chamber flow system illustrated in Fig. 2. To maintain anaerobiosis, even during photosynthetic oxygen production, the algal suspension was continuously purged with ultra-high-purity $\mathrm{O}_{2}$-free carrier gas at $30 \mathrm{ml} / \mathrm{min}$. Therefore, regular respiration or chloroplast respiration play no role in the experiments performed under anaerobiosis, either in helium or $\mathrm{CO}_{2}$ in helium. The experimental technique for measuring the simultaneous photoevolution of oxygen and hydrogen has been previously described. ${ }^{24}$ Even though it totally lacks Photosystem I, sustained simultaneous photoevolution of hydrogen and oxygen was observed, demonstrating that a Photosystem II-driven reaction can span the potential difference between water oxidation/oxygen evolution and proton reduction/hydrogen evolution. The reversible equilibrium thermodynamic potential for these two reactions is $1.23 \mathrm{~V}$. Of course, since the reactions do not occur reversibly at thermodynamic equilibrium, the actual potential must be higher, about $1.4-1.6 \mathrm{~V}^{25}$

In Figs. $1 \mathrm{~A}$ (mutant) and $1 \mathrm{C}$ (wild-type), with $\mathrm{CO}_{2}$ present in the carrier gas, it can be seen that there is an initial surge of hydrogen which peaks and then declines to zero while the light is still on. This hydrogen photoevolution pattern for wild-type Chlamydomonas has been previously analyzed and reported ${ }^{18}$ Briefly, when the algae have been dark adapted, the Calvin-Benson cycle is shut off. Consequently, upon illumination all reducing equivalents are shunted through the ferredoxin/hydrogenase pathway. As the Calvin-Benson cycle is activated by light, it becomes the exclusive sink for reducing equivalents. The monotonic decrease in the rate of hydrogen production from its peak value represents the real-time activation of the $\mathrm{CO}_{2}$ reduction cycle. When the light is turned off, thermally activated hydrogen evolution is observed. This pattern repeats itself when the light is turned on again. The source of thermally activated hydrogen is reduced carbon, identified by Klein and Betz as primarily starch, that has been stored during previous photosynthesis. ${ }^{26}$ C. reinhardtii grows quite well in an anaerobic atmosphere consisting of $\mathrm{CO}_{2}$ and helium. ${ }^{27}$ In a pure helium atmosphere, illustrated by the data of Figs. 1B and 1D, the hydrogen time profiles are qualitatively different. They climb monotonically to an approximate steady state production rate with the light turned on and return to zero when it is turned off. Since $\mathrm{CO}_{2}$ is not present in this atmosphere, the Calvin cycle is not activated and does not serve as a sink for reducing 


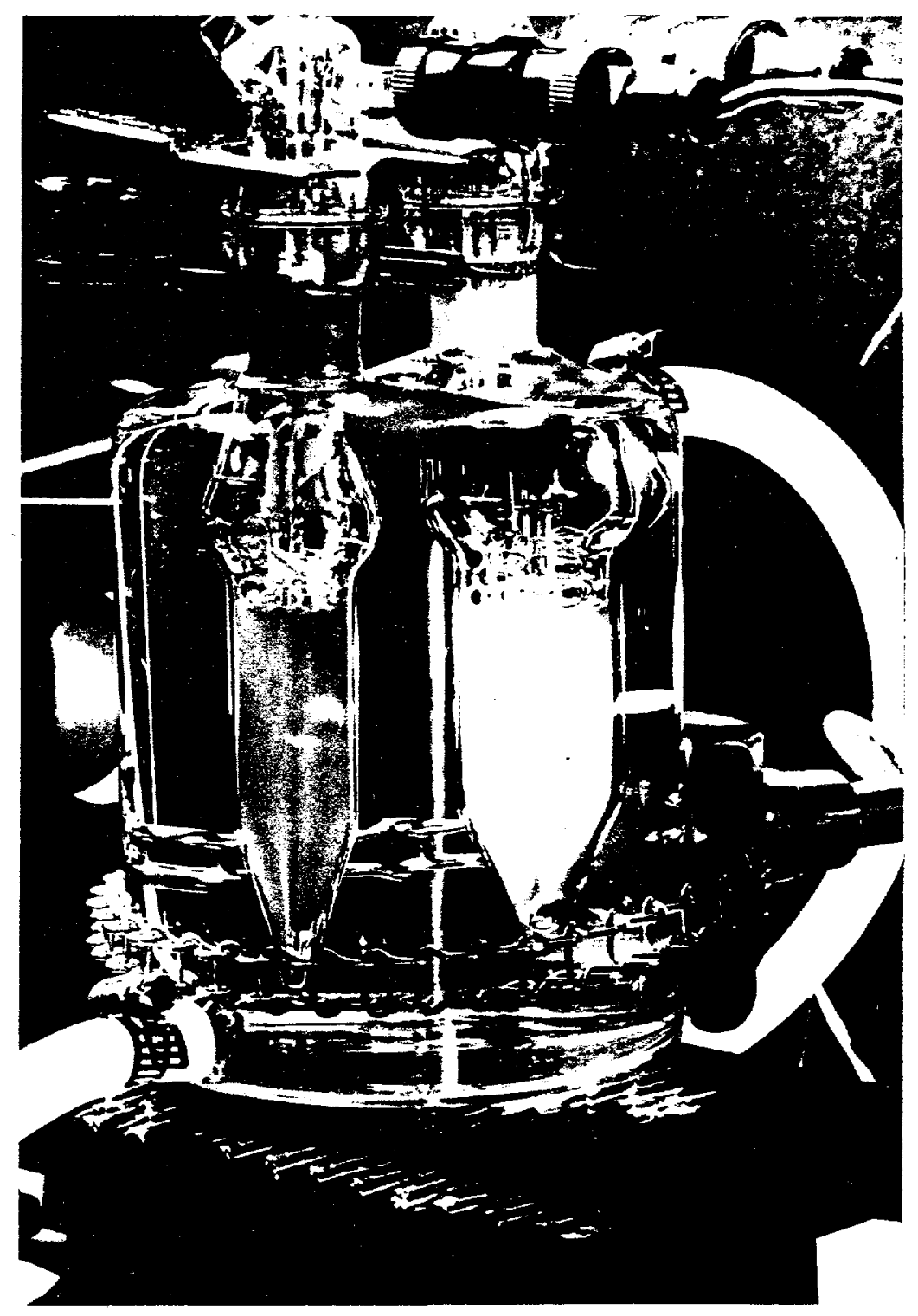

Figure 2. Photograph of postirradiated algae in air with $500-\mathrm{W} / \mathrm{m}^{2}$ white light corresponding to the data of Fig. 2B. Left: wild-type Chlamydomonas $137 \mathrm{c}$; Right: Chlamydomonas mutant B4. The initial chlorophyll concentration of each sample was the same at the start of the experiment. The final concentration of the wild-type alga increased following irradiation, whereas B4's chlorophyll diminished. The algae were illuminated for 23 hours at $20^{\circ} \mathrm{C}$. The algal chamber on the right containing the bleached sample of B4 appears larger in diameter due to the lens effect of the water jacket surrounding both identical chambers. 
equivalents. Oxygen activity is less in helium, presumably due to the absence of $\mathrm{CO}_{2}$ and the Photosystem II bicarbonate requirement. ${ }^{28}$ Irradiation with $\lambda>700$-nm light (which supports PSI but not PSII) in the wild-type alga (Fig. 1C insert) results in a low, but significant, rate of hydrogen evolution. The source of reducing equivalents for this PSI-dependent hydrogen production is the pool of reduced electron carriers in the electron transport chain linking the two photosystems. Under strict anaerobic conditions, this pool is replenished by the reserve of endogenous reductants described above. For B4 (also shown in the Fig. 1C insert), $\lambda>$ $700 \mathrm{~nm}$, as expected, shows no PSI hydrogen production component. Instead, thermally activated hydrogen evolution was suppressed. These control data, in conjunction with the controls described above, indicate the absence of PSI before, during, and after the experiments.

Perhaps the most remarkable aspect of the data for mutant $\mathrm{B} 4$ for $\mathrm{CO}_{2}$ in helium (Fig. 1A) is that the Calvin cycle is evidently activated in this system and serves as an electron sink. This is positively demonstrated by the data of Fig. 3 in which the photoassimilation of $\mathrm{CO}_{2}$ by both mutant and wild-type is illustrated. It therefore follows that mutant $\mathrm{B} 4$ can perform complete oxygenic photosynthesis using a single Photosystem II reaction. As seen in Fig. $3 \mathrm{~A}, \mathrm{CO}_{2}$ photoassimilation is stable for both mutant $\mathrm{B} 4$ and wild-type Chlamydomonas in an anaerobic atmosphere. However, only the wild-type alga, containing both Photosystems I and II, is stable in air. Within 24 hours, mutant B4 lost $90 \%$ of its photosynthetic activity. Figure 2 illustrates the postirradiated algae, cultures of wild-type and mutant B4 in air, with the latter completely bleached. Thus we conclude that PSI is required for oxygenic photosynthesis, in aerobic environments (the normal condition in nature) but not under anaerobic conditions. Since the oxidant generated in Photosystem II must be more oxidizing than $+0.8 \mathrm{~V}$, it follows that a single Photosystem II reaction center has the thermodynamic potential to perform complete photosynthesis, as does the energy content of a single photon absorbed by PSII. Thus, although our findings are novel and unexpected, they do not violate known thermodynamic properties of the photosynthetic system. 


\section{Photoassimilation of $\mathrm{CO}_{2}$ in Helium and Air for Wild-Type and Mutant B4 Chlamydomonas reinhardtii}

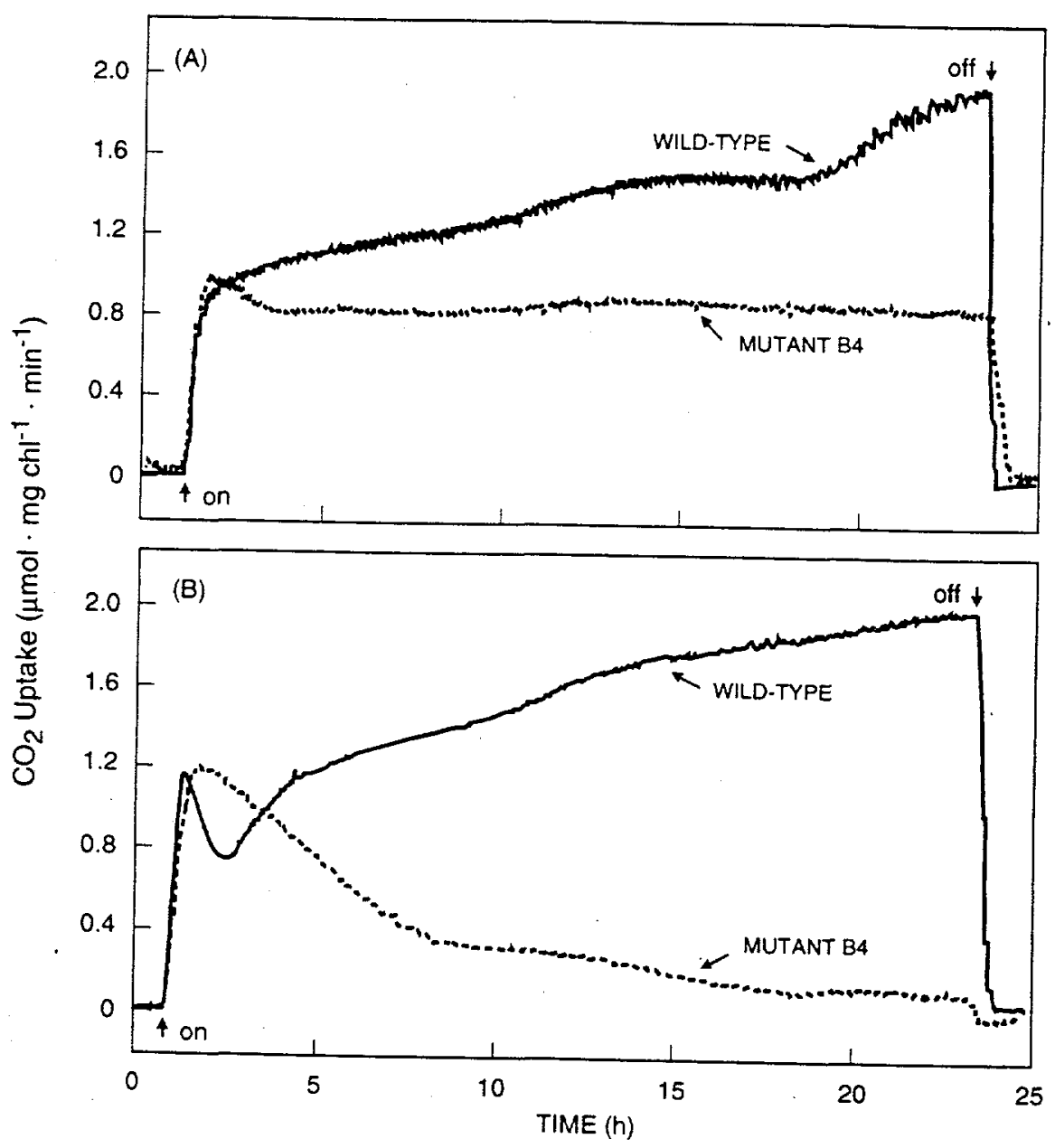

Figure 3. A comparative study of photosynthesis between mutant $B 4$ and wild-type $137 \mathrm{c}$ in anaerobic and aerobic atmospheres. (A) $363 \mathrm{ppm} \mathrm{CO}$ in helium; (B) $363 \mathrm{ppm} \mathrm{CO}_{2}$ in air. The loss of photosynthetic activity by mutant $\mathrm{B} 4$ indicated in Fig. $2 \mathrm{~B}$ was accompanied by a bleaching of its chlorophyll. See Fig. 2 for a visual comparison. Continuous measurement of $\mathrm{CO}_{2}$ was achieved with an in-line infrared spectrophotometer. The $\mathrm{CO}_{2}$ detector was calibrated using an electronic gas blender with primary standard gas mixtures of $\mathrm{CO}_{2}$ in helium. 


\section{DISCUSSION}

A number of observations in the literature have possibly suggested that PSII alone could reduce ferredoxin and thus $\mathrm{NADP}^{+}$. Working with Chlamydomonas ACC-1, a mutant that lacked Photosystem I, Klimov et al. ${ }^{29}$ observed the photoreduction of $\mathrm{NADP}^{+}$. However, oxygen evolution was not demonstrated, and this was interpreted as a non-physiological reaction, an alternative electron pathway occurring only at high light intensities. Boychenko et al., ${ }^{30}$ utilizing a polarographic technique, were able to observe transient evolution of both hydrogen and oxygen from a mutant of Chlamydomonas that was deficient in PSI. Arnon and Barber ${ }^{31}$ reported the photoreduction of $\mathrm{NADP}^{+}$by isolated reaction centers of Photosystem II with 1,5-diphenylcarbazide as the electron source. However, the reaction centers of this work were not functional oxygen evolution preparations, possible PSI contamination was not excluded, and the key emphasis of the Arnon-Barber paper was the requirement for plastocyanin. More recently, Allakhverdiev and Klimov ${ }^{32}$ demonstrated the requirement of manganese for anaerobic photoreduction of $\mathrm{NADP}^{+}$by Photosystem II of higher plants. The primary electron acceptor of Photosystem II is pheophytin, which has an $E_{m}$ of $-0.61 \mathrm{~V}^{33-35}$

Irrespective of specific molecular mechanisms, our data clearly illustrate a new type of photosynthesis being performed by the Photosystem II light reaction. These experiments also have implications for the evolution and origin of water-splitting photosynthesis. Anoxic photosynthetic bacteria exhibit two different mechanisms characterized by either pheophytinquinone or Fe-S type reaction centers. Blankenship ${ }^{36}$ proposed that "some sort of genetic fusion event took place between two bacteria" producing a chimeric organism. Subsequently, the two systems were linked, and the oxygen evolution system was added. However, no examples of the intermediate stages have been observed. Our data support an alternative hypothesis: a bacterium containing the pheophytin-quinone reaction center developed into the oxygen-evolving PSII type of photosynthesis, with Photosystem I being added later for survival when molecular oxygen became a major component of the earth's atmosphere. Data which support this theory are presented in Figs. 3A and 3B. 
From a practical point of view, a single-light reaction implies that the maximum thermodynamic conversion efficiency of light energy into chemical energy, as represented by the Gibbs free energy of molecular hydrogen or reduced carbon, can be potentially doubled, from about $10 \%$ to $20 \%$, since a single photon rather than two is now required to span the potential difference between water oxidation/oxygen evolution and proton reduction/ hydrogen evolution. This is obviously not the case for the data of Figs. 1 and 3 where, under identical conditions, B4 and wild-type have similar quantum efficiencies. However, further studies on algal mutants may achieve the desired result of increased light conversion efficiency.

\section{REFERENCES}

1. J. Deisenhofer and J. R. Norris (Eds.), The Photosynthetic Reaction Center, Vols. I and II, Academic Press, 1993 (San Diego).

2. C. Ley and D. C. Mauzerall, Biochim. Biophys. Acta 680, 95-106 (1982).

3. H. Gaffron, pp. 3-277 in Plant Physiology: A Treatise, Vol. IB, F. C. Steward, Ed. (Academic Press, NY, 1960).

4. R. K. Clayton, Photosynthesis: Physical Mechanism and Chemical Patterns, Chapter 3 (Cambridge Univ. Press, Cambridge, MA, 1980).

5. O. Warburg, D. Burk, V. Schocken, and S. B. Hendricks, Biochim. Biophys. Acta 4, 335-346 (1950).

6. O. Warburg and D. Burk, Arch. Biochem. Biophys. 25, 410-443 (1950).

7. R. Emerson, Ann. Rev. Plant Physiol. 9, 1-24 (1958).

8. R. J. Emerson and C. M. Lewis, Am. J. Bot. 30, 165-178 (1943).

9. R. Hill and F. Bendall, Nature 186, 136-137 (1960).

10. L. N. M. Duysens, J. Amesz, and B. M. Kamp, Nature 190, 510-511 (1961).

11. J. Franck, pp. 142-146 in Research in Photosynthesis, edited by H. Gaffron et al., (Interscience, NY, 1957).

12. W. M. Latimer, pp. 29-50 in The Oxidation States of the Elements and Their Potentials in Aqueous Solutions, 2nd Edition (Prentice-Hall, NY, 1952). 
13. E. Greenbaum, Biotechnol. Bioeng. Symp. 10, 1-13 (1980).

14. T. Hiyama, Physiol. Veg. 23, 605-610 (1985).

15. J. W. Lee, Ph.D. Dissertation, Cornell University, 1993, p. 131.

16. S. Lien and A. San Pietro, An Inquiry into Biophotolysis of Water to Produce Hydrogen, NSF RANN GI 40253 (1975).

17. H. Gaffron and J. Rubin, J. Gen. Physiol. 26, 219-240 (1942).

18. D. A. Graves, C. V. Tevault, and E. Greenbaum, Photochem. Photobiol. 50, 571-576 (1989).

19. N. I. Bishop, M. Fricke, and L. W. Jones, pp. 13-22 in Biological Solar Energy Production, edited by A. Mitsui, S. Miyachi, A. San Pietro, and S. Tamura (Academia Press, NY, 1997).

20. C. Roitgrund and L. Mets, Curr. Genet. 17, 147-153 (1990).

21. P. Bennoun and N.-H. Chua, pp. 33-39 in Genetics and Biogenesis of Chloroplasts and Mitochondria, edited by Th. Böcher, W. Neupert, W. Sebald, and S. Werner (1976).

22. M. Thurnauer and D. Zhang, personal communication (1994).

23. Y. Choquet, M. Goldschmidt-Clermont, J. Girard-Bascou, U. Kok, P. Bennoun, and J.-D. Rochaix, Cell 52, 903-913 (1988).

24. E. Greenbaum, Photobiochem. Photobiophys. 8, 323 (1984).

25. B. Bouges-Boquet, Biochim. Biophys. Acta 594, 85-103 (1980).

26. U. Klein and A. Betz, Plant Physiol. 61, 953-956 (1978).

27. D. A. Graves, G. M. Spradlin, and E. Greenbaum, Photochem. Photobiol. 51 (1990).

28. A. Stemler and Govindjee, Plant Physiol. 52, 119-123 (1973).

29. V. V. Klimov, S. I. Allakhverdiev, and V. G. Ladygin, Photosyn. Res. 10, 355-361 (1986).

30. V. A. Boychenko, S. I. Allakhverdiev, V. G. Ladygin, and V. V. Klimov, Doklady Akad. Nauk, 995-998 (1986). 
31. D. I. Arnon and J. Barber, Proc. Natl. Acad. Sci. USA, 87, 5930-5934 (1990).

32. S. I. Allakhverdiev and V. V. Klimov, Z. Naturforsch. 47c, 57-62 (1992).

33. V. V. Klimov, A. V. Klevanik, V. A. Shuvalov, and A. A. Krasnovsky, FEBS Lett. 82, 183-186 (1977).

34. V. V. Klimov and A. A. Krasnovsky, Photosynthetica 15, 592-609 (1981).

35. V. V. Klimov, S. I. Allakhverdiev, S. Demeter, and A. A. Krasnovsky, Doklady Akad. Nauk SSSR 249, 227-230 (1979). 



\title{
5. COAL COMBUSTION RESEARCH
}

\author{
C. S. Daw
}

This section describes research and development related to coal combustion being performed for the Fossil Energy Program under the direction of the Morgantown Energy Technology Center. The two key activities involve the application of chaos theory to diagnosis and control of fossil energy processes and the characterization of liquid and char coproducts from mild gasification of coal. 


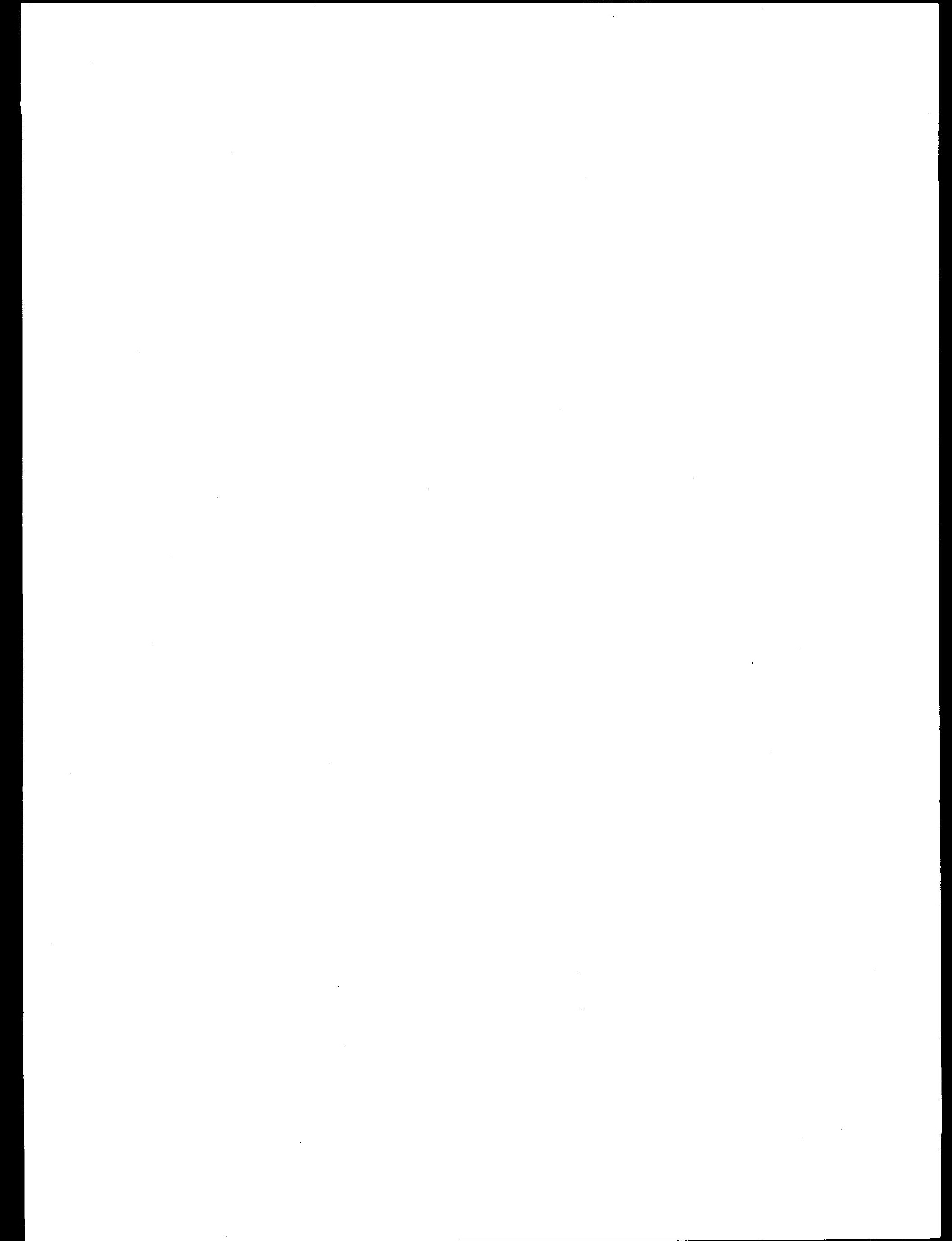




\title{
5.1 ANALYSIS OF FBC DETERMINISTIC CHAOS
}

\author{
C. S. DAW
}

\section{INTRODUCTION}

It has recently been discovered that the performance of a number of fossil energy conversion devices such as fluidized beds, pulsed combustors, steady combustors, and internal combustion engines are affected by deterministic chaos. It is now recognized that understanding and controlling the chaotic elements of these devices can lead to significantly improved energy efficiency and reduced emissions. Application of these techniques to key fossil energy processes are expected to provide important competitive advantages for U.S. industry.

\section{DISCUSSION OF CURRENT ACTIVITIES}

Analysis of fluidized bed, pulsed combustion, and bubble column measurements has continued during this reporting period. The onset and nature of chaotic dynamics in each of these devices has been studied in greater detail and potential high-speed control strategies have been developed. Implementation of two different chaos control algorithms on a model of thermal pulsed combustion has shown that it should be possible to significantly reduce the occurence of temperature extremes which can contribute to the formation of thermal NOx and hydrocarbon emissions. Such control could also be applied to reduce transient fluctuations in conventional combustors. Comparison of the nonlinear dynamic structure in pressure measurements from the Tidd PFBC demonstration facility with data from a cold "scaled" fluidized bed have revealed important differences between the MIT bed and Tidd. 
Fluidized Beds and Bubble Columns

Further bubble column experiments have confirmed the onset of chaos via period doubling for viscous liquids such as glycerin. Qualitative similarities in the experimental return maps for this experiment as compared with those reported for a chaotic dripping faucet suggest important similarities between the two systems. Modifications are now being planned for the experiment to test the implementation of closed loop control for this system. Two methods for introducing control perturbations that are now being considered are pressure pulsations in the bubble injection tube and injection of "perturbation" bubbles via a horizontally offset injector. A paper summarizing our observations of period doubling and the onset of chaos was presented at the 1994 AIChE National Meeting in San Francisco (1). Efforts have also been initiated to improve the model of bubble dynamics developed previously (2).

We have continued studies of slugging control using small pulses of injected air near the gas distributor. The timing of the air pulses is controlled based on high speed pressure measurements from the bed, resulting in either augmentation or disruption of the slugs. The amount of air contained in the pulses is typically $1 \%$ or less of the fluidization air. Further increases in slugging control efficiency are expected through application of improved control algorithms. Two papers summarizing our results have been submitted for publication $(3,4)$.

As part of our CRADA with Babcock and Wilcox we have made detailed analyses of the dynamic structure of pressure measurements from the Tidd PFBC facility. These analyses have revealed important differences between the behavior of that bed and a cold "scaled" bed at MIT. The MIT cold bed was constructed according to scaling relationships that are expected to produce dimensional similarity with Tidd, thus allowing the MIT bed to be used to simulate the Tidd facility. The observed differences in the dynamic measurements indicate differences in the bubble patterns between the two beds, which suggests that that the scaling relationships are incomplete or based on incorrect assumptions. Further studies are needed to understand the reasons for these differences. A paper summarizing our analysis results has been accepted in the upcoming International Fluidized Bed Combustion Conference (5). 


\section{Pulsed Combustion}

Computer simulations of a thermal pulsed combustor have demonstrated that it is possible to control the chaotic pulsations of the combustor so that the variations in peak temperature and pressure between cycles is dramatically reduced. This control has been accomplished by using a chaos control algorithm known as adaptive recursive proportional feedback which directs small perturbations in the tailpipe flow to bring about the improved operation. Because the controlled combustor has a significantly reduced peak temperature and an elevated minimum temperature, it is expected that there would be significantly less NOx and hydrocarbon emissions. We have also found that the controlled combustor can also be operated at much greater firing rates without reaching flameout. Another chaos control algorithm known as continuous derivative control has been found to stop pulsation altogther. We expect that the latter control mode may be beneficial for conventional continuous combustors which exhibit unwanted oscillations. Two papers have been submitted on these findings $(6,7)$.

\section{REFERENCES}

1. K. Nguyen, P. Chakka, and C.S. Daw, "Chaotic Behavior of Gas Bubbles in a Viscous Liquid," Paper presentation at the 1994 AIChE National Meeting, San Francisco, November 13$18,1994$.

2. C.S. Daw and J.S. Halow, "Modeling Deterministic Chaos in Gas-Fluidized Beds," Fluidized Processes: Theory and Practice, A.W. Weimer, ed., AIChE Symposium Series No. 289, Vol. 88, 1992.

3. M. Vasudevan, C.E.A. Finney, K. Nguyen, N.A. van Goor, D.D. Bruns, and C.S. Daw, "Stabilization and Destabilization of Slugging Behavior in a Laboratory Fluidized Bed," Proceedings of the 13th International Conference on Fluidized Bed Combustion, Orlando, May 7-10, 1995. 
4. C.S. Daw, C.E.A. Finney, M. Vasudevan, N.A. van Goor, D.D. Bruns, E.J. Kostelich, C. Grebogi, E. Ott, and J.A. Yorke, "Self-organization and chaos in a fluidized bed," submitted January 1995 to Physical Review Letters.

5. T.A. Fuller and C.S. Daw, "Dynamic Comparison of Pressure Measurements From the AEP Tidd PFBC and MIT's Quarter-Scale Cold Model," Proceedings of the 13th International Conference on Fluidized Bed Combustion, Orlando, May 7-10, 1995.

6. C.S. Daw, J.F. Thomas, M.A. Rhode, R.W. Rollins, and A.J. Markworth, "Controlling Cycleby-Cycle Variation in a Pulse Combustor," Proceedings of the 1995 Joint Technical Meeting of the Central and Western States Sections of the Combustion Institute and the American Flame Research Committee, San Antonio, April 23-26, 1995.

7. M.A. Rhode, R.W. Rollins, A.J. Markworth, K.D. Edwards, K. Nguyen, C.S. Daw, and J.F. Thomas, "Controlling Chaos in a Model of Thermal Pulse Combustion," submitted November 1995 to the Journal of Applied Physics. 


\title{
5.2 MILD-GASIFICATION PRODUCT CHARACTERIZATION
}

\author{
C.S. DAW
}

\section{INTRODUCTION}

From previous studies it is known that mild gasification of coal produces liquids that are potentially useable as diesel fuel or diesel fuel diluents. However, the yield and quality of these liquids as well as the degree of upgrading required can vary substantially with process severity (i.e., the degree of devolatilization). The combustion properties of product char from mild gasification are also directly affected by process severity. Because the overall economics of mildgasification is heavily dependent on liquid and fuel properties, detailed characterizations of these products are needed to choose from competing processes. ORNL has been tasked to compare the properties of liquid and char products from selected mild-gasification processes being evaluated by the Morgantown Energy Technology Center (METC).

\section{DISCUSSION OF CURRENT ACTIVITIES}

Activity during this reporting period was confined to completing low-temperature char combustion characterizations that were begun in the previous period. Four candidate chars produced by the SGI mild-gasification process from western coals were evaluated in the BenchScale Fixed Bed Reactor Facility at the Babcock and Wilcox Alliance Research Facility. The SGI process is generally described as producing a relatively low degree of devolatilization, and the candidate chars were expected to be high in combustion reactivity. From the results it is clear that the chars are highly reactive (similar in reactivity to raw bituminous and sub-bituminous fuels), but they nevertheless exhibit differences that appear to be associated with the parent coals. It is anticipated that these chars might be suitable as replacement fuels for bituminous fuels in fluidized bed and low-temperature boilers. Pulverized firing tests are also recommended.

A final report containing details of the above char characterizations has been forwarded to Leonard Graham and Harold Shoemaker at METC. No additional work is planned. 


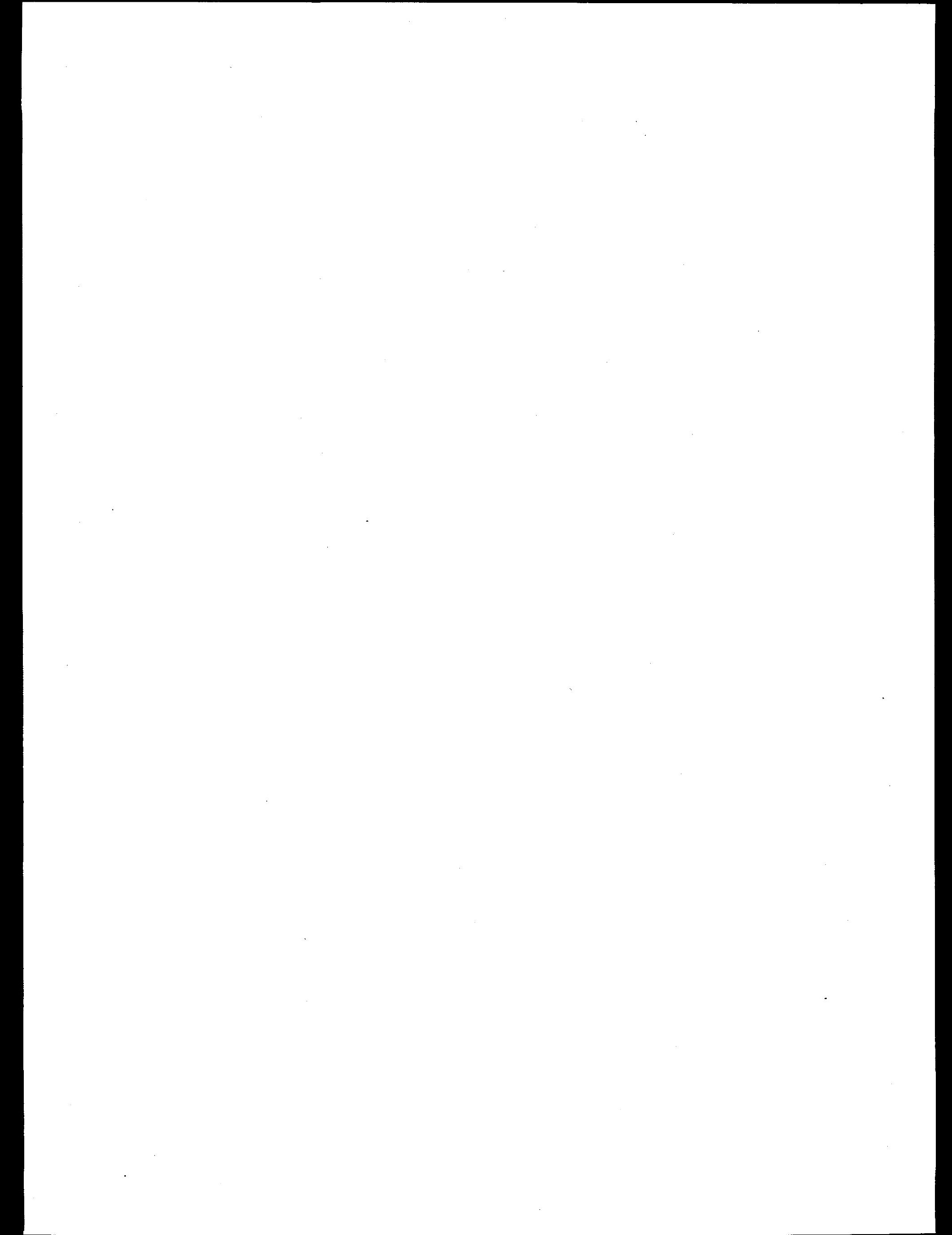




\section{FOSSIL FUELS SUPPLIES MODELING AND RESEARCH}

\subsection{STRATEGIC PETROLEUM RESERVE PLANNING AND MODELING \\ P. N. Leiby}

\section{INTRODUCTION}

The Strategic Petroleum Reserve (SPR) is a government-owned stockpile of crude oil intended to serve as a buffer against possible oil market disruptions. The overall purpose of this project is to develop and apply improved models and tools for SPR management. Current project efforts emphasize developing new modeling tools to explicitly and flexibly portray oil market uncertainty and SPR planning risk.

\section{DISCUSSION OF CURRENT ACTIVITIES}

Oak Ridge National Laboratory (ORNL) conducts model development and planning analyses for Strategic Petroleum Reserve (SPR) drawdown, distribution and other management activities, in support of the Office of Management Operations, Petroleum Reserves. The roles and objectives are:

1. to utilize, maintain, modify, and report on SPR analysis models;

2. to support development of SPR oil valuation and bid analysis tools;

3. to evaluate potential applications of DIS-Risk model approach to related energy policy issues;

4. to study role and value of risk information in SPR planning;

5. to evaluate SPR planning alternatives and roles of SPR;

6. to provide analytical support for the SPR office.

In the last year, ORNL

- Completed technical documentation of the DIS-Risk model;

- Delivered an updated and tested version of the SPR-Risk model (DIS-RI24) which incorporates changing market projections by DOE/EIA, as well as factors such as changed SPR starting size, and changed starting year of analysis. 
- Used the DIS-RISK model to explore the economic effects of alternative SPR utilization policies;

- Assisted the General Accounting Office in using the DIS-RISK model to support its own examination of SPR policies;

- Proposed a variety of methods for determining the market value of SPR crude oils (the challenge here is that SPR oils are blends of other crude types, and in some cases include crude types that are rarely traded);

- Participated in meetings of the Energy Modeling Forum study on energy market risk.

Based on work underway, the DIS-Risk model is being updated to take advantage of the enhanced capabilities of new spreadsheet software, creating an interface more similar to the SPR Office's SAVE or BEV model. Furthermore, moving to this Window-based spreadsheet will allow smoother integration with the risk analysis engine, @Risk, and provide clearer tables and graphs of results. 
7. ADVANCED TURBINE SYSTEMS

\title{
7.1 MATERIALS/MANUFACTURING ELEMENT OF THE ADVANCED TURBINE SYSTEMS PROGRAM
}

\author{
M. A. Karnitz
}

\section{INTRODUCTION}

The DOE Offices of Fossil Energy and Energy Efficiency and Renewable Energy have initiated a program to develop advanced turbine systems for power generation. The objective of the Advanced Turbine Systems (ATS) Program is to develop ultra-high efficiency, environmentally superior, and cost competitive gas turbine systems for utility and industrial applications. One of the supporting elements of the ATS Program is the Materials/Manufacturing Technologies Task. The objective of this element is to address the critical materials and manufacturing issues for both industrial and utility gas turbines.

\section{DISCUSSION OF CURRENT ACTIVITIES}

No contribution was received for work performed during this reporting period. 

ORNL-6874

\section{INTERNAL DISTRIBUTION}
K. Breder
T. D. Burchell
P. T. Carlson (2)
N. C. Cole
D. F. Craig
C. S. Daw
E. Greenbaum
M. A. Janney
R. R. Judkins (5)
M. A. Karnitz
E. N. Kaufman
P. N. Leiby
C. T. Liu

C. G. McKamey

R. L. Miller

T. C. Scott

V. K. Sikka

D. P. Stinton

R. W. Swindeman

P. F. Tortorelli

Central Research Library (2)

Document Reference Section

Laboratory Records Department (2)

Laboratory Records, ORNL - RC

M\&C Records Office (3)

ORNL Patent Section

\section{EXTERNAL DISTRIBUTION}

W. T. Bakker

ELECTRIC POWER RESEARCH

INSTITUTE

P.O. Box 10412

3412 Hillview Avenue

Palo Alto, CA 94303

A. L. Baldwin

DEPARTMENT OF ENERGY

Pittsburgh Energy Technology Center

P.O. Box 10940

Pittsburgh, PA 15236

R. C. Bedick

DEPARTMENT OF ENERGY

Morgantown Energy Technology Center

P.O. Box 880

Morgantown, WV 26505

D. J. Beecy

DEPARTMENT OF ENERGY

FE-14

19901 Germantown Road

Germantown, MD 20874-1290
J. L. Beeson

DEPARTMENT OF ENERGY

Morgantown Energy Technology Center P.O. Box 880

Morgantown, WV 26505

R. G. Bidwell, Jr.

DEPARTMENT OF ENERGY

FE-431, 3G-043/FORS

Washington, DC 20545

J. L. Blough

FOSTER WHEELER DEVELOPMENT

CORPORATION

Materials Technology Department

John Blizard Research Center

12 Peach Tree Hill Road

Livingston, NJ 07039

R. J. Braitsch

DEPARTMENT OF ENERGY

FE-4, 4G-055/FORS

Washington, DC 20545 
W. A. Brown

DEPARTMENT OF ENERGY

Morgantown Energy Technology Center

P.O. Box 880

Morgantown, WV 26505

J. P. Carr

DEPARTMENT OF ENERGY

FE-72

19901 Germantown Road

Germantown, MD 20874-1290

S. W. Chun

DEPARTMENT OF ENERGY

Pittsburgh Energy Technology Center

P.O. Box 10940

Pittsburgh, PA 15236

D. C. Cicero

DEPARTMENT OF ENERGY

Morgantown Energy Technology Center

P.O. Box 880

Morgantown, WV 26505

J. W. Cooke

DEPARTMENT OF ENERGY

Oak Ridge Operations Office

P.O. Box 2008

Oak Ridge, TN 37831-6269

A. B. Crawley

DEPARTMENT OF ENERGY

Bartlesville Project Office

220 North Virginia Avenue

P.O. Box 1398

Bartlesville, OK 74003

F. W. Crouse, Jr.

DEPARTMENT OF ENERGY

Morgantown Energy Technology Center

P.O. Box 880

Morgantown, WV 26505
J. B. Darby

DEPARTMENT OF ENERGY

Office of Basic Energy Sciences

ER-131

19901 Germantown Road

Germantown, MD 20874-1290

DEPARTMENT OF ENERGY

Assistant Manager for

Energy Research and Development

Oak Ridge Operations

P.O. Box 2001

Oak Ridge, TN 37831

DEPARTMENT OF ENERGY

Deputy Assistant Manager for Energy

Research and Development

Oak Ridge Operations Office

P.O. Box 2008

Oak Ridge, TN 37831-6269

DEPARTMENT OF ENERGY

Office of Scientific and Technical

Information

P.O. Box 62

Oak Ridge, TN 37831

R. A. Dennis

DEPARTMENT OF ENERGY

Morgantown Energy Technology Center

P.O. Box 880

Morgantown, WV 26505

L. W. R. Dicks

SHELL DEVELOPMENT COMPANY

P.O. Box 1380

Houston, TX 77251-1380

M. Van de Voorde

EUROPEAN COMMUNITIES JOINT

RESEARCH CENTRE

Petten Establishment

P.O. Box 2

1755 ZG Petten

The Netherlands 
M. L. Eastman

DEPARTMENT OF ENERGY

Pittsburgh Energy Technology Center

P.O. Box 10940

Pittsburgh, PA 15236

E. W. Evans

DEPARTMENT OF ENERGY

Pittsburgh Energy Technology Center

P.O. Box 10940

Pittsburgh, PA 15236

H. Feibus

DEPARTMENT OF ENERGY

FE-232, 3012/270

Washington, DC 20545

S. G. Fishman

OFFICE OF NAVAL RESEARCH

Code 431, 800 N. Quincy Street

Arlington, VA 22217

R. D. Furiga

DEPARTMENT OF ENERGY

FE-40, 3G-024/FORS

Washington, DC 20545

D. W. Geiling

DEPARTMENT OF ENERGY

Morgantown Energy Technology Center

P.O. Box 880

Morgantown, WV 26505

F. M. Glaser

DEPARTMENT OF ENERGY

FE-72, 3037/270

Washington, DC 20545

P. M. Goldberg

DEPARTMENT OF ENERGY

Pittsburgh Energy Technology Center

P.O. Box 10940

Pittsburgh, PA 15236
L. E. Graham

DEPARTMENT OF ENERGY

Morgantown Energy Technology Center

P.O. Box 880

Morgantown, WV 26505

L. G. S. Gray

ALBERTA RESEARCH COUNCIL

Oil Sands Research Department

P.O. Box 8330

Postal Station F

Edmonton, Alberta

Canada T6H5X2

J. S. Halow

DEPARTMENT OF ENERGY

Morgantown Energy Technology Center

P.O. Box 880

Morgantown, WV 26505

S. Harding

CONSOLIDATION COAL COMPANY

4000 Brownsville Road

Library, PA 15129

R. A. Hargis

DEPARTMENT OF ENERGY

Pittsburgh Energy Technology Center

P.O. Box 10940

Pittsburgh, PA 15236

A. M. Hartstein

DEPARTMENT OF ENERGY

FE-32, 4067/270

Washington, DC 20545

J. L. Hebb

DEPARTMENT OF ENERGY

Pittsburgh Energy Technology Center

P.O. Box 10940

Pittsburgh, PA 15236

S. P. Henslee

ARGONNE NATIONAL

LABORATORY-WEST

P.O. Box 2528

Idaho Falls, ID 83403-2528 
J. D. Hickerson

DEPARTMENT OF ENERGY

Pittsburgh Energy Technology Center

P.O. Box 10940

Pittsburgh, PA 15236

J. M. Hobday

DEPARTMENT OF ENERGY

Morgantown Energy Technology Center

P.O. Box 880

Morgantown, WV 26505

E. E. Hoffman

DEPARTMENT OF ENERGY

Oak Ridge Operations

P.O. Box 2008

Building 4500N, MS 6269

Oak Ridge, TN 37831

N. T. Holcombe

DEPARTMENT OF ENERGY

Morgantown Energy Technology Center

P.O. Box 880

Morgantown, WV 26505

C. M. Huang

TENNESSEE VALLEY AUTHORITY

Energy Demonstration \& Technology

MR 2N58A

Chattanooga, TN 37402-2801

W. J. Huber

DEPARTMENT OF ENERGY

Morgantown Energy Technology Center

P.O. Box 880

Morgantown, WV 26505

L. A. Jarr

DEPARTMENT OF ENERGY

Morgantown Energy Technology Center

P.O. Box 880

Morgantown, WV 26505

R. A. Johnson

DEPARTMENT OF ENERGY

Morgantown Energy Technology Center

P.O. Box 880

Morgantown, WV 26505
S. L. Lai

DEPARTMENT OF ENERGY

Morgantown Energy Technology Center

P.O. Box 880

Morgantown, WV 26505

S. R. Lee

DEPARTMENT OF ENERGY

Pittsburgh Energy Technology Center

P.O. Box 10940

Pittsburgh, PA 15236

A. M. Manaker TENNESSEE VALLEY AUTHORITY

1101 Market Street

3A Missionary Ridge

Chattanooga, TN 37402-2801

G. V. McGurl

DEPARTMENT OF ENERGY

Pittsburgh Energy Technology Center

P.O. Box 10940

Pittsburgh, PA 15236

T. J. McMahon

DEPARTMENT OF ENERGY

Morgantown Energy Technology Center

P.O. Box 880

Morgantown, WV 26505

D. R. Messier

ARMY MATERIALS TECHNOLOGY

LABORATORY SLCMT-MCC

Watertown, MA 02172-0001

H. S. Meyer

GAS RESEARCH INSTITUTE

8600 West Bryn Mawr Avenue

Chicago, IL 60631

W. R. Miller

DEPARTMENT OF ENERGY

Morgantown Energy Technology Center

P.O. Box 880

Morgantown, WV 26505 
C. L. Miller

DEPARTMENT OF ENERGY

FE-22, 3111/270

Washington, DC 20545

H. M. Ness

DEPARTMENT OF ENERGY

Morgantown Energy Technology Center

P.O. Box 880

Morgantown, WV 26505

J. E. Notestein

DEPARTMENT OF ENERGY

Morgantown Energy Technology Center

P.O. Box 880

Morgantown, WV 26505

J. Oakey

BRITISH COAL CORPORATION

Coal Technology Development Division

Stoke Orchard, Cheltenham

Glocestershire, England GL52 4ZG

Aksel Olsen

RISOE NATIONAL LABORATORY

P.O. Box 49

DK-4000

Roskilde, Denmark

S. E. Rogers

DEPARTMENT OF ENERGY

Pittsburgh Energy Technology Center

P.O. Box 10940

Pittsburgh, PA 15236

T. C. Rupel

DEPARTMENT OF ENERGY

Pittsburgh Energy Technology Center

P.O. Box 10940

Pittsburgh, PA 15236

L. A. Ruth

DEPARTMENT OF ENERGY

Pittsburgh Energy Technology Center

P.O. Box 10940

Pittsburgh, PA 15236
T. A. Sarkus

DEPARTMENT OF ENERGY

Pittsburgh Energy Technology Center

P.O. Box 10940

Pittsburgh, PA 15236

C. E. Schmidt

DEPARTMENT OF ENERGY

Pittsburgh Energy Technology Center

P.O. Box 10940

Pittsburgh, PA 15236

D. K. Schmidt

DEPARTMENT OF ENERGY

Morgantown Energy Technology Center

P.O. Box 880

Morgantown, WV 26505

R. C. Searles

MOBIL RESEARCH \& DEVELOPMENT CORPORATION

P.O. Box 1026

Princeton, NJ 08540

T. B. Simpson

DEPARTMENT OF ENERGY

FE-231, 3003/270

Washington, DC 20545

M. I. Singer

DEPARTMENT OF ENERGY

FE-70, 4G-052/FORS

Washington, DC 20545

C. A. Smith

DEPARTMENT OF ENERGY

Pittsburgh Energy Technology Center

P.O. Box 10940

Pittsburgh, PA 15236

W. A. Steele

LAWRENCE LIVERMORE NATIONAL LABORATORY

P.O. Box $808, \mathrm{~L}-325$

Livermore, CA 94550 
J. Stringer

ELECTRIC POWER RESEARCH

INSTITUTE

P.O. Box 10412

3412 Hillview Avenue

Palo Alto, CA 94303

D. F. Swink

DEPARTMENT OF ENERGY

EE-20, 6B-052/FORS

Washington, DC 20545

T. M. Torkos

DEPARTMENT OF ENERGY

Pittsburgh Energy Technology Center

P.O. Box 10940

Pittsburgh, PA 15236

D. B. Uthus

DEPARTMENT OF ENERGY

FE-221, 3113/270

Washington, DC 20545

J. E. Walsh

DEPARTMENT OF ENERGY

FE-10, 3049/270

Washington, DC 20545

W. L. Warnick

DEPARTMENT OF ENERGY

ER-412

19901 Germantown Road

Germantown, MD 20874-1290

R. Wolk

ELECTRIC POWER RESEARCH

INSTITUTE

P.O. Box 10412

3412 Hillview Avenue

Palo Alto, CA 94303

C. M. Zeh

DEPARTMENT OF ENERGY

Morgantown Energy Technology Center

P.O. Box 880

Morgantown, WV 26505
E. A. Zuech

DEPARTMENT OF ENERGY

Bartlesville Project Office

220 North Virginia Avenue

P.O. Box 1398

Bartlesville, OK 74003 